\title{
THE \\ Lineage Book \\ OF THE \\ Order of Washington
}

1. G. B. BULLOCH, M. D. THANCHLLOR-OJNERAL

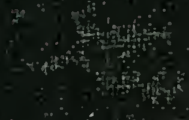

YYY 
P.1.

$\mu M$

Q 21

P. 23

225. 
x 1. 



\section{THE \\ Lineage Book \\ OF THE \\ Order of Washington}

BY

J. G. B. BULLOCH, M. D.,

CHANCELLOR-GENERAL

235883 


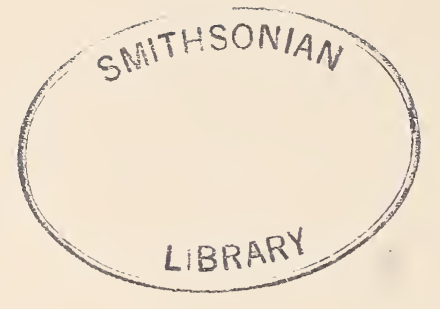


$\cup 929$
$B$

\section{DEDICATED}

To Hon. Hugh Vernon Washington, Orator and Philanthropist. 


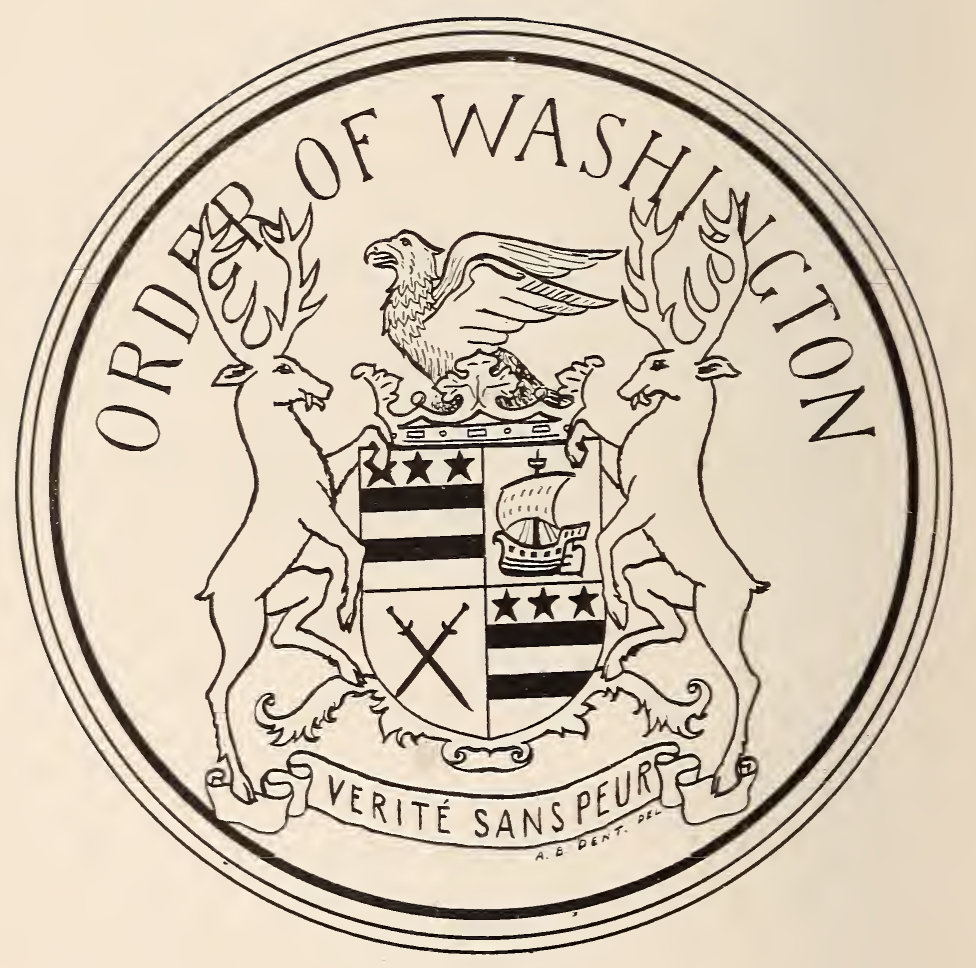




\section{HISTORY OF ORDER.}

This Order was founded at Mobile. Ala., in 1895, and, as far as I am aware, is the only one named for the illustrious general and statesman, George Washington. Our members having become separated, the Order remained in absyance when an attempt was made by Mr. Jorn Eyerman, of Easton, Pa., and myself, to revive the Order. The former having a die cast for the beautiful insignia now adopted by us, and also some handsome invitations issuerl, containing upon their face the necessary qualifications of admittance to the Order. Nothing further was done until I bicame permanently settled in this city, when I determined to reorganize the Order, and with the assisiance of certain gentlemen, we placed it upon a firm basis, and on May I3, I908. formally instituted the Order and received a Charter for the same on June II, I908, so that we have the satisfaction of knowing that The Order of Washington is now firmly established, and as a qualification for membership requires that the ancestor must have arrived in America before I75\%, have been a landowner or founder of a town, held some official, military or ministerial position in the Colonial service, and had a descendant who aided the Colonies in attaining their independence.

\section{J. G. B. Bulloch, M.D.,}

Chancellor-General.

At a meeting held at the residence of Commander Charles C. Rogers, U. S. N., on the I3th of May, I908, it was resolved that an order of patriotism and chivalry be formed to be called The Order of Washington, named for the illustrious General George Washington. The following gentlemen were present at this meeting:

Commander C. C. Rogers, U. S. N.

General Marcus J. Wright.

Dr. J. G. B. Bulloch.

Mr. Ethelbert Fairfax.

Mr. Cuthbert B. Brown.

Mr. Howard P. Wright. 


\section{THE ORDER OF WASHINGTON.}

WHEREAS, It should be the duty of all those of illustrions lineage to preserve intact the history and traditions relating to the foundation of their country, and to endeavor to promote peace, happiness, and the general welfare of mankind, therefore, we, the founders of this Order, should use our influence to see that our institutions are kept intact and free from pernicious influences and that freedom and liberty be promoted: Therefore, we whose names are subjoined do now institute an order of patriotism and chivalry to be known as The Order of Washington.

\section{ARTICLE V.}

\section{Qualifications.}

In order to become a member of this Order the ancestor must have arrived in America prior to I750, have been a landowner or a founder of a town, and have held some official. military (naval) or ministerial position in Colonial days, and also had a male descendant who assisted the Colonies in attaining their independence.

In order to explain the above the following clause is offered:

The candidate to become a Companion in this Order must have ciescended in the male or female line from a male ancestor who assisted the Colonies in attaining their independence, and the revolutionary ancestor must have descended in the direct male line from an ancestor who was in the Colonies prior to 1750 and who or whose son held at some time an official position during the Colonial period, or, was a founder of a town, or, was in the military or naval service, or was a minister of the Gosrel. 


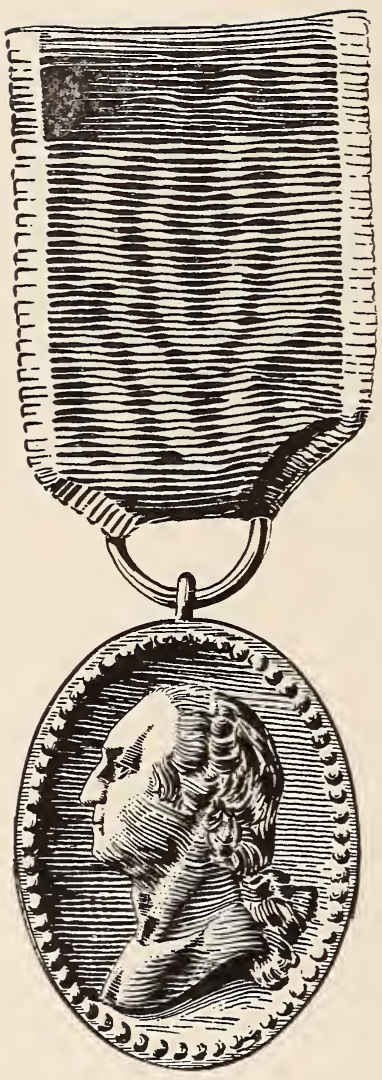




\title{
Tist of Officers and Companions of the Order of Vulasbington
}

\author{
Dfficers \\ CoMTMANDER General \\ Rear Admiral Chas. H. Stockton, U. S. N \\ Retired \\ Vice-Commander General \\ General Marcus J. Wright \\ 2D Vice-Compander Generai, \\ Ethelbert Fairfax \\ 3D Vice-Commander General \\ Dr. Edwin Allston Hill \\ 4Th Vice-Commander Generai. \\ Col. G. Noble Jones \\ 5 Th Tice-Commander Generai, \\ Dan'1 Smith Gordon \\ 6th Tice-Commander General \\ Capt. Chas. C. Rogers, U. S. N. \\ 7th Vice-Commander Geinerai. \\ James M. Johnston \\ 8th Vice-Commander General \\ Archie Lre Talbot \\ OTH Vice-Comanander General \\ Howard P. Wright \\ Chancellor General \\ Dr. J. G. B. Bulloch
}


Vice-Chancellor General

Orra E. Monnette

SECRETARY-GENERAI

Alfred B. Dent.

Assistant SeCrettary-General

Thomas Campbell Washington

HISTORIAN-GENERAL

Dr. Wm. Berrien Burroughs

TREASURER-GENERAL,

Dr. Charles H. Bowker

REGISTRAR-GE,NERAL

William M. Conrad

RECORDER-GENERAL

Dr. Lonis D. Carman

JUdGe-Advocate General

Col. I. W. Littell, U. S. A.

SURGEON-GENERAL

Dr. Francis J. Woodman

Master of Ceremonies

Henry P. Holden

KEEPER OF THE SFAL

William Bowie

HERALD

Cuthbert Barnwell Brown

Marshal

Capt. Philip E. M. Walker, U. S. A., Retired STANDARD BEARER

Dr. Thomas J. W. Brown 
Assistant Standard BFarers

Capt. Thomas Washington Philip Contee Hungerford

Capt. S. I. Bayard Schindel, U. S. A. CHAPLAIN-GENER.IL

Rev. Geo. Livingston Bayard, U. S. N. Depury Vice-Commanders for the States California, Willis Milnor Dixon, Los Angeles

Colorado, Lucius M. Cuthbert, Denver Connecticut, Arthur Adams, Ph.D., Hartford Dist. of Col., Dr. Charles Neil McBryde, Washington Georgia, C. W. King, Rome Illinois, Thomas Bonniwell, Chicago Indiana, Charles A. Bonniwell, Auburn Kansas, D. O. Munson, M. D., Pittsburg Maine. Philip Foster Turner, Portland Maryland, Geo. Norbury McKenzie, Baltimore Massachusetts, Eiliot Albert Clark, Pittsfield

Ninnesota, Carlton Baker Talbot, Akely Mississippi, Rev. Dr. Wm. M. Pettis, Washington Missouri, A. M. Holcombe, St. Louis New Hampshire, Judge E. M. Bowker, Whitefield New Jersey, Geo. Castor Martin, Asbury Park New York, Franklin D. Roosevelt, New York City North Carolina, Capt. S. A. Ashe, Raleigh

Pennsylvania, W. I. Rutter, Philadelphia South Carolina, Prof. C. J. Colcock, Charleston Texas, Otto Holstein, San Antonio Virginia, Dr. Lyon G. Tyler, Williamsburg

Washington, F. Moser Hamilton, Seattle West Virginia, R. D. Shepherd, Shepherdstown 


\section{Companions of the Proer of Vulasbington}

Adams, Dr. Arthur, Trinity College or 823 Broad St., Hartford, Conn.

Arthurs, Edward Ferguson, 628 Equitable Building, Baltimorc, Md.

\#Ashe, Capt. S. A., Care Senator Simmons, Senate Bldg.. Washington, D. C., Raleigh, N. C.

Bayard, Rev. George Livingston, U. S. N., Care Secretary of the Navy, Washington, D. C.

\#Baylor, Armistead, Keith, 30 Church St., New York, N. Y.

\# Baylor, Major Eugene, Winchester, Va.

\#Bedon, Josiah, I3I I South 2oth St., N. W., Washington, D. C.

Bonniwell, Charles A., Auburn, Indiana.

Bonniwell, Judge Eugene C., The Municipal Court, Philadelphia, Pa.

Bonniwell, Thomas J., 5465 Dorchester Are., Chicago, Ill. Bowie, William, 2020 P St., N. W., Washington, D. C.

\# Bowker, Dr. Charles H., of N. H., I204 Mass. Ave., N. W., Washington, D. C.

\#Bowker, Judge E. M., Whitefield, N. H.

Bowker, Hon. M. H., Whitefield, N. H.

Brooke, Francis John Taliaferro, Charlestown, W. Va.

\#Brown, Cuthbert B.. i7 ro Conn. Ave., N. W., Washington, D. C.

\#Brown, George E., P. O. Box 2535, Boston, Mass.

\#Brown, George Whitfield, iz Io Conn. Ave., N. W., Washington, D. C.

\#Brown, Dr. Thomas J. W., The Westchester, Washington. D. C.

\#Bulloch, Douglas Eugene St. Cloud, Savannah, Ga., The Ostavia, r669 Col. Rd. N. W., Washington, D. C.

\#Bulioch. Dr. J. G. B., Savannah, Ga., i669 Col. Rd. N. W., Washington, D. C.

\# Signifies Charter Members. 
=Bulloch, Robert Hutchison, Savannah, Ga., Office Chief Engr., A. C. L. R. R., Wilmington, N. C.

\#Bulloch, William Gaston Glen, Savannah, Ga., The Octavia, r669 Col. Rd. N. W., Washington, D. C.

Burroughs, Dr. Wm. Berrien, Brunswick, Ga.

*Carman, Dr. Louis D., I35I Q St. N. W., Washington, D. C.

Campbell, J. D., Drawer 690, El Paso, Texas.

Capp Seth Bunker, P. O. Box 2054, Philadelphia, Pa.

\#Chandler, Peleg W., Jamaica Plains, Boston, Mass.

Chase, Ernest L., P. O. Box No. I435, Dallas, Texas.

Clark, Addison L., Gilboa, N. Y.

Clark, Elliot Albert, I7 Buel St. or Berkshire County Bank, Pittsfield, Mass.

Colcock, Prof. Charles Jones, Porter Military Academy, Charleston, S. C.

\#Conrad, Wm. M., Florence Court (Star Office), Washington, D. C.

\#Cox, Edwin Birchard, P. O. Box No. I234, Ir 28 Old South Bldg., Boston, Mass.

Culver, Francis B., I25 22nd St., Baltimore, Md.

\#Cuthbert, Lucius Montrose. P. O. Box No. I465, Denver, Colo.

*Cuthbert, Dr. Middleton Fuller, 1462 R. I. Ave. N. IV., Washington, D. C.

\#Dent. Alfred B., 906 A St. S. E., Washington, D. C.

Dixon, Willis Milnor, 8I4 San Fernando Bldg. (or 200 Arapahoe St.), Los Angeles, Cal.

\#Elmore, Frank Harper, South Carolina, r729 Riggs St. N. W., Washington, D. C.

\#Fairfax, Ethelbert, of Virginia, I602 H St., Washington, D. C.

Feamster, Lt. Claudius Newman, U. S. A., Louisburg, W. Va.

Franks, Herbert Marvin, U. S. Custom House and Post Office Building, Charleston, S. C.

\# Signifies Charter Members. 
Franks, Rutherford Garlington, Laurens County, Laurens C. H., S. C.

\#Gerald, H. P., Room 309, Patent Office, Washington, D. C.

Gordon, Daniel Smith, The Decatur, Fla. Ave. and 2oth St., Washington, D. C.

Habersham, Edward H., Annapolis, Md.

Hamilton, F. Moser, 57 io I 8th Ave., N. E., Seattle, Wash.

Harden, Edw. Thomas, 8I 4 San Fernando Bldg., Los Angeles, Cal.

Hart, Dr. Wm. Lee (Captain, U. S. A.), Ft. Sam Houston, Texas.

Heath, John, of California, The Wyoming, Washington, D. C. Heth, Capt. Stockton, I409 Mass. Ave. N. W., Washington, D. C.

Hildreth, Dr. Walter H., I344 Parkwood Place, Washington, D. C.

\# Hill, Dr. Edwin A., Patent Office, Washington, D. C.

\# Hitchcock, Frederick H., I05 W. 4oth St., New York City, N. Y.

\# Holden, Henry P., Pension Office, Washington, D. C.

\# Holcombe, A. M., 5 Io Pine St., St. Louis, Mo.

Holstein, Otto H., Box 1216, San Antonio, Texas.

\# Howkins, John S., Liberty St., Savannah, Ga.

\#Hungerford, Philip Contee, The Portner, Washington, D. C.

\# Hunter, Lt. Tracy Gould, Jr., U. S. M. S., Care Secretary of the Navy, or Savannah, Ga.

Hunter, Robert Williamson, I76I R St. N. W., Washington, D. C.

\# Johnston, James M., I628 2 Ist St., N. W., Washington, D. C. \# Jones, Col. G. Noble, Exchange Bldg., Savannah, Ga. \# King, C. W., Rome, Ga.

King, Harris Macleod, Savannah, Ga.

\# King, James Nephew, Rome, Ga.

\#Littell, Col. Isaac W., U. S. A., 3204 I8th St., N. W., Washington, D. C.

\#Signifies Charter Members. 
Loomis, Archie Harwood, is Princeton Place, Upper Mont Clair, N. J.

$=$ Lunt, Wm. Wallace, Higham, Mass., Boston, Mass.

McBryde, Dr. Charles Neil, The Iroquois, Washington, D. C.

MIcCowan, Robert J. F., 35 North Pearl St., Bridgeton, N. J. Mackenzie, Geo. Norbury, 2 East Lexington St., Baltimore, Id.

Martin, George Castor, Care of Martin \& Allardyce, Asbury Park, N. J.

Meredith, William Payne, i6 E. Melrose, Chery Chase, Md. Middleton, Arthur E. H., 223 A St. S. E., Washington, D. C. Monnette, Orra E., 308-3Io South Broadway, Los Angeles, Cal.

\#.Nuncaster, Dr. Stenart B., 907 I6th St. N. W., Washington, D. C.

Munson, Dr. Dunham O., 204 Globe Bldg., Pittsburg, Kans.

Page, Hon. Thomas Nelson, Virginia, Care of Secretary of State, Washington, D. C.

Parks, Frank Sylvester, I6og Hobart St. N. W., Washington, D. C.

\# Pettis, Rev. Dr. Wm. M., I72+ Corcoran St. N. W.. Washington, D. C.

\# Pettis, John Baylor, IS I 7 U Street N. W., Washington, D. C. \# Poullain, James Potter, of Georgia, Baltimore, Md.

Ray, Preston Blair, Rockville, Md.

Richards, H. M. M., Lebanon, Pa.

\# Rogers, Capt. Charles C., U. S. N., Care of Secretary of the Navy, Washington, D. C.

Roosevelt, Hon. Franklin Delano, I733 N St. N. W., Washington, D. C.

Rulison, George W., City Court, New York City, New York. Rutter, William Ives, 525 South 4Ist St., Philadelphia, Pa. \#Sawtelle, Dr. Henry F., 300 I I ith St. N. W., Washington, D. C.

\# Signifies Charter Members. 
\# Schindel, Capt, S. J. Bayard. I7+7 I8th St. N. W., Washington, D. C.

= Shepherd, R. D., I925 Biltmore St. N. W., Washington. D. C.

= Smith. Sidney F.. Patent Office, or 2238 Cathedral Are., Wrashington, D. C.

St. Clair, Dr. Francis A., I3I9 T St. X. WV., Washington, D. C.

Stillman. Dr. Thomas B., Ph. D., M. Sc., Sterens Institute of Technology, City Hall. Jersey City. N. J., Hoboken, N. J.

Stewart, J. McDonald, Pension Office or 1922 H St. N. II., Washington, D. C.

= Stockton, Rear Admiral Chas. H., 2019 O St. N. W., Wash. ington, D. C.

Talbot, Archie Lee, I 57 Pine St., Lewiston, Maine.

Talbot, Carlton Baker, Akely, Minn.

Talbot, Ralph Lee, I 57 Pine St., Lewiston, Maine.

Talbot, William Wiggin, 79 Birch St., Bangor, Maine.

Turner, Dr. Francis M., Io Bolton St. West, Savannah, Ga.

Turner, Harlan Barzillai, to Exchange St., Portland, Maine.

Turner, Philip Foster, No. to Exchange St., Portland, Maine.

Thomson, Alfred Ray, U. S. Consular Service.

Thomson, Dr. Lewis Beecher, $3+23$ I6th St. N. IV., Washington, D. C.

\#'Tyler, Dr. Lyon Gardiner, William \& Mary College, Wiiliamsburg, Va.

Van Voast, Horace Silliman, 5I I State St., Schenectady, N. Y.

Vaughan, Dr. George Tully, I7ı8 I St. N. W., Washington, D. C.

Young, Laurens Garlington, Union, S. C.

\#Walker. Capt. Philip E. M., U. S. A., Page Brook. Clarke County, Virginia.

\# Vashington, Lawrence, 216 A St. S. E.. Washington, D. C.

\# Signifies Charter Members. 
\#Washington, R. Wirt, The Portner, Washington, D. C.

Washington, Thomas Campbell, The Cordova, Washington, D. C.

Washington, Capt. Thomas, 2I I5 Bancroft Place, Washington, D. C.

White, Richard Neville, 253 Depew Ave, Buffalo, N. Y.

\# Willey, Capt. W. L.. Ancient \& Hon. Arty. Co., Faneuil Hall, Boston, Mass.

\#Woodman, Dr. Francis J., 634 A St. N. E., Washington, D. C.

\#Wright. Howard P., P. O. Box No. 906. San Antonio, Texas.

\#Wright, Captain John, U. S. A., Eagle Pass, Tex.

\#Wright, Gen. Marcus J., I743 Corcoran St. N. W., Washington, D. C.

\section{Ibonotaty SiDember}

Mrs. E. Washington Bellamy. 



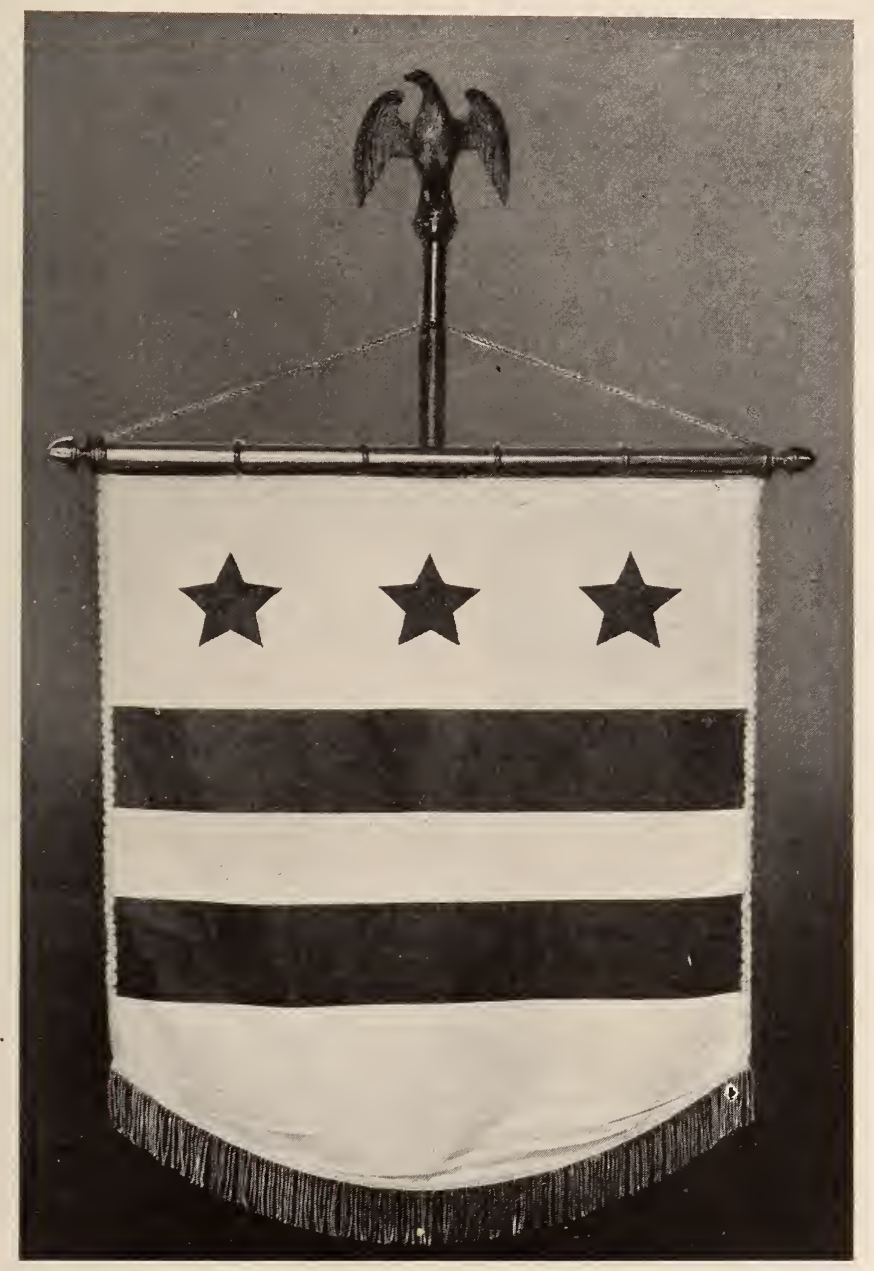





\section{In STemoriam}

I * Bail, R. Mason, Paymaster U. S. N., Washington, D. C.

2 Dunwody, Major Jeff. D., Atlanta, Ga.

3 \#Grigsby, Hart P., Jefferson County, Ky.

4 Haskins, C. D., Schenectady, N. Y.

5 \#Washington, Col. J. A., Goldsboro, N. C.

6 \#Washington, Hon. Hugh Vernon, Macon, Ga.

7 Washington, Wm. De Hertburn, Virginia.

8 \#Woodruff, General Carle A., U. S. A., Raleigh, N. C.

\# Signifies Charter Members. 


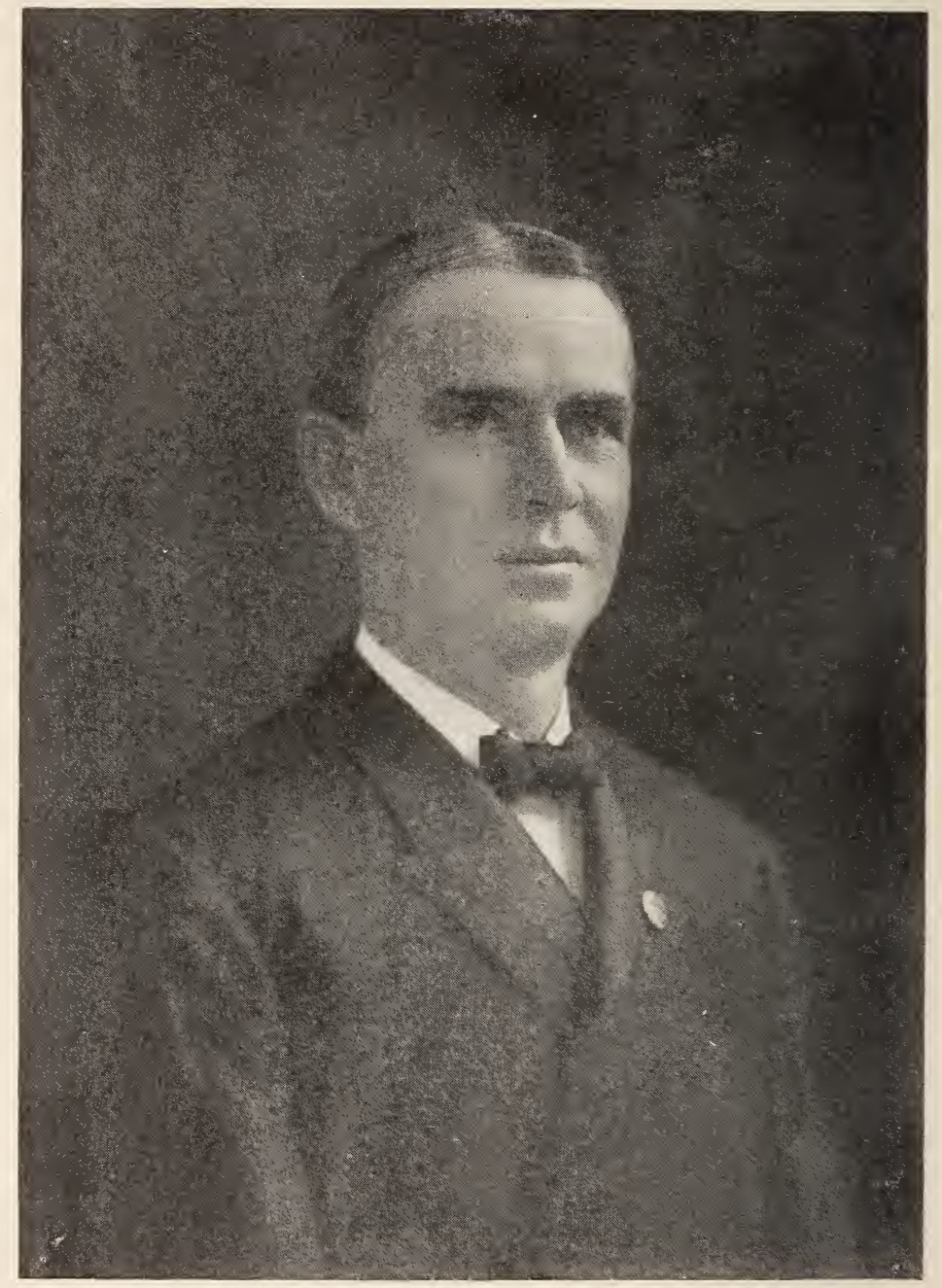

$$
\begin{aligned}
& \text { Ning Restee tfully Sinto } \\
& \text { ctugh V. maskuighs }
\end{aligned}
$$




\section{ADAMS.}

Arthur Adams. Professor of English in Trinity College, Hartford. Connecticut, was born at Pleasantville. New Jerser, May I2, I88I, on the homestead whicin had been in the family for orer two hundred years. His parents were James R. and Marietta (English) Adams. Professor Adams began his education in the public schools of his native town, but at the age of twelve years, owing to the death of his father, the family moved to Ocean City, New Jersey, where he continued his education. Here he graduated from the public school, thus preparing. with the help of a private tutor, for College. In September of 1898 he entered Rutgers College, New Brunswick. New Jersey, from which institution he was graduated B. A. in the Class of 1902.

After graduation from College. Professor Adams spent the next succeeding three years in the graduate study of English at Yale University, receiving the degree of M. A. in I903 and of $\mathrm{Ph}$. D. in 1905. In September, 1905, he began his career as a teacher as an Instructor in English in the University of Colorado. The next year, he became an Assistant Professor of English in Trinity College. In 1908 he was made Associate Professor, and in IqI I Professor, becoming Head of the Department in I9I4.

Professor Adams is also in Priest's Orders in the Episcopal Church, having been ordained to the Priesthood by Bishop Brewster of Connecticut, May I3, I909, at Windsor, Connecticut. He received the degree of B. D. from the Berkeley Divinity School in I9Io.

Professor Adams has written books and articles for periodicals on subjects related to his chosen field of scholarly activity. $\mathrm{He}$ is also a competent genealogist. and has published articles in the New England Hist. and Gen. Register, the New York Gen. and Biog. Record, and the Pennsylvania Magazine of History and Biography, as well as several genealogical 
pamphlets. He is a member of various learned societies, such as the American Philological Association and the Modern Language Association of America; of several historical societies; of many social clubs and societies; and of these patriotic societies-the Order of Washington, the Colonial Order of the White Crane, the National Genealogical Society, the Swedish Colonial Society, the Order of Founders and Patriots, and the Society of Colonial Wars. Also member of Phi Beta Kappa Society, and of the Imperial Order of the Yellow Kose: member Society Scions of Colonial Cavaliers and Knights of the Golden Horseshoe.

June 22, I9I0, Professor Adams was married to Miss Emma G. Steelman of Ocean City, New Jersey, daughter of Hiram and Mary Jane (Jackaway) Steelman. A daughter, Esther Steelman Adams, was born to them December 30. I9I2. The Steelman family is one of the oldest and best known of Southern New Jersey. Tize progenitor was James Steelman, Gentleman, probably of Swedish.origin, who appeared in Creat Egg Harbor, Gloucester County, New Jersey, as early as I693. Among the distinguished families of New Jersey from whom Mrs. Adams claims descent may be mentioned the Somers, Conover, Edwards, Ingersoll, and Barrett families. She also is an enthusiastic and able genealogist, having collected and arranged the data for a genealogy of the descendants of James Steelman, and much material relating to other families. Mrs. Adams is a member of the Society of the Colonial Dames of New Jersey and of the Society of the U. S. Daugliters of I8r2.

The progenitor of the Adams family to which Professor Adams belongs was Jeremy Adams, who came, it is supposed, from Essex County, England, to Cambridge, Massachusetts. in I632. He was an original proprietor of Hartford, Connecticut, where he was prominent, serving under Captain Mason against the Indians and engaging in the grain trade. He was proprietor of the Inn for many years. After his death the Inn was kept by Lieutenant Zachary Sanford, who had married his granddaughter, and it was from this Inn, where the General Court met, that the famous Connecticut Charter was 
stolen and hidden in the equally famous Charter Oak. Jeremy Adams was the first settler and the original proprietor of the town of Colchester, Connecticut. He died August I I, I683. The line of descent is Jeremy, John, Jonathan (of Huntington. Long Island, and Great Egg Harbor, New Jersey), John, John, Daniel, and James R. John, the great grandfather of Professor Adams, served during the Revolution as an Ensign in the Gloucester County, New Jersey militia, and his father in the I5th New Jersey Volunteers during the Civil War. All the Adams family have served well their day and generation.

Professor Adams' mother, Marietta English, was a descendant of Joseph English, who settled in Burlington, New Jersey. in I6-8. coming frem Nailsworth, Gloucester County, Englanıl. John, son of Joseph, settled at English Creek, Gloucester County, New Jersey, in I7I4, owning extensive tracts of timber land and sawmills. He was a Justice of the County Court for many years. Joseph, son of John, served as a private in the New Jersey militia during the Revolution. The Lake and the Collins families are among the prominent connections of the English family. He also descends from the Springer family, through which he becomes a member of the Imperial Order of the Yellow Rose.

Professor Adams' great grandmother was Margaret Garwood, wife of Ensign John Adams. The Garwood family was of Burlington County, New Jersey, and Margaret Garwood numbered among her ancestors representatives of many of the best Quaker families of West Jersey. Among her ancestors may be mentioned Richard Hancock of Salem, New Jersey, who came over with Fenwick, in I675, and who served as Surveyor General, member of the West Jersey Assembly in I682, as Judge, etc.; Henry Ballenger, member of the West Jersey Assembly in I697; Walter Humphreys; George Elkinton, etc., all early settlers and proprietors of West Jersey.

Professor Adams' favorite avocation is the study of history and genealogy, and he takes pride in his connection with patri. otic, lereditary, and histcrical societies. 


\section{ARTHURS.}

Edward Ferguson Arthurs, A. Mi., of Baltimore, MA., born in Pittsburgh, Pa., August 2, I857 ; only child of Edward Arthurs and Ann Catherine Ferguson. He was baptised on Novemb:21, I857, in St. Peter's Protestant Episcopal Church, Pittsburgh, by Rev. Edwin Martin Van Dusen, Rector. Moved to Allegheny City, Pa., I859, and to Baltimore, Md., I868. Educated in private schools, studied at Hampton-Sidney College, Va.. I874-5, and while there joined the Beta Theta Pi Fraternity: entered Princetion College I875, graduated I\&:79; receivei degree of L.L. B. from the University of Maryland, I882; admitted to the Baltimore Bar, I882, and received degree of A. M. from Princeton College, i882.

On October I I, I882, married Elizabeth B. Neilson, who liicd I905, leaving surviving her three daughters Ann Catherine, M. Montgomery and Elizabeth Arthurs. Married a second time in I90.8, Adeline Schanze.

He is Deputy Secretary of the Society of Colonial Wars in the State of Maryland, Historian of the Society of the Sons of the Revolution in the State of Maryland, Registrar of the Maryland Society of the Sons of the American Revolution, Treasurer of the Society of the War of 18 I 2 in the State of Maryland, and one of the Executive Committee of the General Society of the War of I8I2. Represented each of said societies respectively at the General Assembly, Triennial meeting of the General Society, National Congress, and the Biennial meeting of the General Society. Member of Maryland Historical Society, the University Club of Baltimore, the Baltimore Athletic Club, the Automobile Club of Maryland, the Princeton Alumni Association of Maryland, the League of American Wheelmen, the St. Andrew's Society, the St. David's Society, the German Society of Baltimore, the City Club, the National Geographical Socisty, the Y. M. C. A. of Baltimore and Brown Memorial Presby terian Church.

MATERNAL Line.

Mother-Ann Catherine Ferguson, born March 30, 1825, 
Kingston, Ohio, died October 31, I 895, Baltimore, Md. ; married July 22, I854, in Cincinnati, O., Edward Arthurs (born March 20, I8I6, died October 3I, I859, Pittsburgh, Pa.) He was the 6th child of Col. William Arthurs, born December 24, I784, in Carlisle, Pa., died March 9, I857, in Pittsburgh ; married November 6, I806, in Pittsburgh, Maria Martin (born 1790, died July 24, I850).

Grandfather-IVilliam Ferguson, born August I6, I786, in Franklin County, Pa., died January 28, I865, Cincinnati, O., married January 8, I824, Eliza Crouse (born June 27, I806, in Ross County, O., died June 9, I889, in Baltimore). Youngest child of John Crouse, son of John, born January I3, I759, in Frederick County, MId., died Sept. 5, I847, in Kingston, O. (was a soldier in the Revolution from Maryland), and Catherine Umsted, born May 1, I764; married March 20, I780, in Frederick County, Md., died September I2, I845, in Kingston, O. : daughter of Nicholas Unnsted, born I733, died February I3, I797. and Ann Davis, born I739, died August 19, I797, in Frederick County.

On August 22, I8I2, he enlisted in Capt. John McNeal's Company of Cavalry, Ohio Militia, War of I8I2, from Ross County, $\mathrm{O}$.

Great Grandfather-Natthew Ferguson, born I749, in County Antrim, Ireland, of Scotch parentage: died November 2, I848, in Pickaway County, O.: married $\mathrm{I} 782$ in Hamilton Township, Cumberland County, Pa., Ann Chesnut (born December I2, I764, died December 24, I85 I, in Pickaway County, O., daughter of John Chestnut, son of William; born I7 I5, died February I3, I8Io ; married May I2, I748, Catherine Greg ; born I709, died Nay I2, I800.

He was a private in Capt. John William's Company of 4 th Rattalion of Cumberland County, Pa., Militia Flying Camp, and was in service in and around Philadelphia, Pa., at the battles of Prandywine and Germantown. Also a private in Cant. Samuel Patterson's Second Company, 5th Class, , th Battalion, Cumberland County Militia, with his brother, his law kin and $h$ is neighbors. 
Great, great Grandfather-James Ferguson, born (cir) I723 ; died I772 ; married I744, Rachel Walker ; died I79I. Came to America from County Antrim, Ireland, cir. I750, and finally settled in that part of Hamilton Township (formed I752), Cumberland County (formed I750 from Lancaster County), which is now in the bounds of Hamilton and St. Thomas Townships, Franklin County (erected in I784), to the west of Chambersburg.

Was Sergeant in James Patterson's Company, July 25, I757. at Ft. Halifax, Pa., and on February 3, I758, at Fort Hunter, Pa. McCauley, in his Historical Sketch of Franklin County, Pa., says:- "So rapid were the movements of these companies and so daring their exploits, that they struck terror into the minds of their savage enemies and kept the frontier safe from ravages for a time." In 1768 , he, with several others, signed a letter to the Provincial Governor deploring the rescue from jail of two men who had been arrested for the murder of ten Indians.

He attended Rocky Spring Presbyterian Church, about four miles north of Chambersburg, and with his wife is buried in its graveyard.

\section{BALL.}

Richard Thomas Mason Ball, U. S. Navy, was born in Loudoun County, Va., May I6, I857, and was the son of George Washington Ball and Mary Beverly Randolph, grandson of Fayette Ball (Godson of General LaFayette and General Washington) and Mary Thomson Mason, great grandson of Colonel Burgess Ball (cousin of General Washington) and Frances Wasinington, niece of General Washington, great great grandson of Jonathan Ball, born July 9, I725, and Elizabeth, daughter of Charles Burgess of England, great, great, great 
grandson of Major James Ball and Mary Daingerfield, great, great, great, great grandson of Captain Williaiz Ball of Millinbeck, born June 2, I641, died September 30, I674, and Margaret Douremain.

Colonel Burgess Ball of the Continental Line was born in Virginia on July 28. I749, and died in Loudoun County, Va., 'sn March 7, i800. He was a cousin, and nephew by marriage of General George Washington and aid on his staff : ancl later was Colonel of a regiment equipped entirely from his private purse.

His ancestor, Colonel William Ball, was a Colonial officer and landowner and was in Virginia as early as i667. Paymaster Ball of the Navy was a genial, courteous Virginia gentleman, and this Order has met a great loss in his death. The sse him descended from the ancient families in direct line of Ball. Randolph, Mason. Burgess, Daingerfield and Washington, illustrious families of the Old Dominion.

\section{BAYARL.}

Rev. George Livingston Bayard, Chaplain, U. S. Navy: rank of Major, was born in the State of New York and comes of the ancient and distinguished family of Bayard.

His ancestry at the North embraces such well-known fam. ilies as Stuyvesant, Van Cortlandt, Livingston, Schuyler, Van Brugh, Cuyler, and others; and at the South the highly honorable family of Hon. Noble Jones and Hon. John Glen, Chief Justice of Georgia, $1776-78$, of the ancient family of Glen of Bar. He is the son of John Murray Bayard and Rose E. Howell and grandson of Nicholas James Bayard and Sarah. daughter of Noble Glen, son of Judge John Glen and Sarah, daughter of Dr. Noble Wimberley Jones, the sterling 
patriot who was a delegate to the Continental Congress and one of the foremost to advance the cause of liberty in Georgia. Dr. Noble Wimberley Jones married Sarah, a daughter of John Davis, a planter in Georgia, who held official position there. The father of Dr. Jones was the Hon. Colonel Noble Jones, who went to the Colony of Georgia in I733 with his friend, General James Edward Oglethorpe, and held many places of prominence, such as Member of the King's Council, Treasurer of the Province and other responsible positions.

Nicholas James Bayard above was born in Georgia and was the son of Dr. Nicholas Serl Bayard, born in Philadelphia, Pa., October 8, 1774, died in Savannah, Ga., Novemlser 21. I82I. He married Ann Livingston Bayard, a cousin, who was a daughter of Nicholas Bayard of New York by his first wife, Catharine Livingston, a daughter of Peter Van Brugh Livingston, first President of New York Provincial Congrcss, and his wife, Mary, daughter of James Alexander, member of Council and Surveyor General of New Jersey, by Maria Spratt, widow of Samuel Proovost and daughter of John Spratt, representative of Assembly 1690-93-95. who married Maria Schrick, widow of Paulius Schrick and daughter of Johannes de Peyster, Burgomaster, etc., in New York, whose wife was Cornelia Lubberts, a relative of the De La Noys. Peter Van Brugh Livingston was the second son of Philip Livingston, second Lord of the Manor of Livingston, by Catharine Van Brugh, daughter of Peter Van Brugh and Sarah Cuyler, and Philip Livingston was the son of Robert Livingston, first Lord of the Manor, who married Alida Schuylar, daughter of Philip Peterse Schuyler. Nicholas Bayard of New York was the son of Nicholas Bayard and Elizabeth Rynders, son of Samuel Bayard by Margarita Van Cortland. bap. April, I674, daughter of Caot. Stephen Van Cortland and Gertruyd Schuyler, son of Col. Nicholas Bayard and Judeth Verlet or Varleth, and Col. Nicholas Bayard was son of Samuei Bayard, who married Ann Stuyresant, sister of Peter Shuyresant, first Dutch Governor of New York. As the maternal line 
of Chaplain Bayard's grandfather has now been given we will now give his paternal line. Dr. Nicholas S. Bayard was one of the sons of the distinguished Col. John Bayard of the Revolutionary War, who held so many positions of prominence. He married Margaret McCulloch, dau. of Andrew McCulloch and Jane Hodge. Col. John Bayard was the son of James Bayari and Mary Asheton, and the latter James Bayard was the son of Samuel Bayard, born New Amsterdam, I675, son of Petr11s Bayard, Deacon in Dutch Church and Alderman in New York. who married, 1674, Blandina Kierstede, daughter of Surgeon Hans Kierstede. Petrus Bayard was the brother of the distinguished Col. Nicholas Bayard, one of the principal personages in early New York history, and of Catharine Bayard and Balthazer Bayard. the children of Samuel Bayard and Ann Stuyvesant. We thus see that Chaplain George Livingston Bayard is descended from the two brothers, Col. Nicholas and Petrus Bayard, which lines converge upon the marriage of Dr. Nicholas S. Bayard, who married his cousin. Ann Livingston, daughter of Nicholas Bayard, of New York.

\section{BEDON.}

Josiah Bedon was born in Chester, South Carolina, and comes of a long line of ancestors who were among the founders of America.

He is the son of Josiah Bedon, Captain in the army of the Confederate States, who married Mary Camfield McLure of Chester, S. C., a lady descended from the McLures of Revolutionary War and from the Gastons of North Carolina. She also descends from the ancient family of Ogden and other illustrious ancestry. Capt. Josiah Bedon was the son of Col. 
Richard B. Bedon of Walterboro, S. C., who was a statesman and planter. He married Jane Bulloch Lowndes Perry, daughter of Dr. James M. Perry and Frances Hunter, daughter of Dr. James Hunter. Dr. James M. Perry was the son of Josiah Perry and Jane Bulloch, daughter of Hon. James Bulloch and Jean, daughter of Rev. Archibald Stobo and Elizabeth Park, daughter of James Park, writer, in Edinburgh. Scotland.

Col. Richard B. Bedon was the son of Josiah Pendarvis, who took his mother's name of Bedon, and Josiah Pendarvis or Bedon married Elizabeth Louisa Stobo, daughter of Richard Park Stobo, who married November 24, I750, Mary Harvey.

Richard Park Stobo was the son of James Stobo, planter, and Elizabeth, son of the prominent Presbyterian Minister, Rev. Archibald Stobo and Elizabeth Park. See articles on Bulloch and Moser for full particulars as to Bulloch and Stobo, and also "A history of Bulloch, Stobo and Irvine of Cults."

\section{WILLIAM BOWIE}

Was born at "Grassland," Annapolis Junction, Anne Arundel County, Maryland, May 6th, i872. Was educated at St. John's College, Annapolis, Maryland; Trinity College, Hartford, Connecticut; and Lehigh University, South Bethlehem. Pennsylvania. He received the degree of Bachelor of Science in 1893, and the honorary degree of Master of Arts in 1907. from Trinity College, and the degree of Civil Engineer in I895 from Lehigh University. He took an active part in athletics, playing on the 'Varsity football and baseball teams. $\mathrm{He}$ is a member of the Phi Beta Kappa honorary society.

He entered the field service of the United States Coast and 
Geodetic Survey in 1895, and for fourteen years was engaged upon various coast and geodetic surveys in many States of the Union, and in Alaska, Porto Rico, and the Philippine Islands. In 1909 he was appointed Inspector of Geodesy and Chief of the Computing Division of the Coast and Geodetic Survey, with offices in Washington, D. C., the position he now holds. $\mathrm{He}$ is the author of a number of government publications which give the results of researches in terrestrial gravity and in other geodetic subjects, and is a contributor to numerous scientific journals. In I9I 2 he was one of two delegates representing the United States at the seventeenth general conference of the International Geodetic Association held at Hamburg, Germany. $\mathrm{He}$ is a member of the Cosmos Club of Washington, and of a number of societies-scientific, engineering, and geographic, and in I9I4 was president of the Washington Society of Engineers.

He married Miss Elizabeth Taylor Wattles of Alexandria, Virginia. They have one son, Clagett, born February 6th, I907.

William Bowie is the son of Thomas John and his wife Susannah Anderson Bowie. His direct male line is as follows :

Son of Thomas John Bowie, born I837; died I898.

Grandson of John Bowie, born I799; died.I87I.

Great grandson of Thomas Bowie, born 1767 ; died $I_{1} \&_{2}$.

Great-great grandson of Allen Bowie, Jr., born about I7367 ; died 1803 .

Great-great-great grandson of John Bowie, Jr., born about I708; died 1753 .

Great-great-great-great grandson of John Bowie, Sr., born about I688; died I759.

John Bowie, Sr., emigrated from Scotland to Maryland absut I 705-6.

Allen Bowie, Jr., was a captain in the 29th Battalion of the Maryland forces in the Revolutionary War. In I 774 and I 775 was a delegate to conventions held at Annapolis to protest against the Stamp Act, and to devise means for resistance.

Thomas John Bowie, John Bowie and Thomas Bowie ware members of the Maryland legislature. 
On his father's side he is also descended from the following ancestors who took part in the Revolutionary War, or the public affairs of the Colony of Maryland.

Thomas Gantt, Sr., the emigrant-I683, one of the Justices of the Quorum, and his Majesty's justice of the peace in I689.

Dr. Thomas Gantt, chairman of the Provincial Counci! in I775, and a member of the Association of Freemen the same year. He was a member of the Committee of Safety in I774, I 776 and I777, and Clerk of Calvert County in 1776.

Levi Gantt, a soldier in the Revolutionary War.

Joseph Belt, in I725 patented Chevy Chase, Md.; Justice for Prince George County I726-I728. Member of the House of Burgesses 1725-I737; Lieutenant Colonel I725, Colonel I728: member of Colonel George Beall's Troop of Horse I748; one of the founders of Rock Creek Parish I726.

Dr. Humphrey Belt, a captain in the Revolutionary War.

Benjamin Tasker, President of the Council and Deputy Governor of the Maryland Colony.

Colonel Ninian Beall, who in I699 was made commander-inchief of the colonial forces of Maryland.

Robert Brooke, born I602-died I663, who came to Maryland in I650, was "Commander" of Charles County and had a seat in the Privy Council; in 1652 was made President of five commissioners appointed for the government of the Colony of Maryland.

Major Thomas Brooke, born I632-died 1676. In 1660 commissioned Major of Colonial forces, and in I66I led an expedition against the Indians. In 1673 he was elected a member of the General Assembly.

Colonel Thomas Brooke, born I660-died I730, was elected to the General Assembly a number of times, and was appointed a member of the Upper House. In I720 was elected president of the Council; he was also a Justice of the Peace.

On his mother's side William Bowie is descended from:

Richard Duckett, Sr., first clerk of Queen Anne's Parish. Richard Duckett, Jr., an officer in the Maryland militia 
in the Revolutionary War, a Justice of the Peace and of the Quorum.

Mareen Duvall, a French Huguenot emigrant, who settled in Anne Arundel County in 1659. He was appointed one of the commissioners to survey and lay off towns and ports of entry in the County. He was rewarded by the Province for services against the Nanticoke Indians in 1683 .

Rev. Henry Hall, who came to Maryland in 1698 , and in that year was inducted as the first rector of St. James Parish, Anne Arundel County. A few years later he was appointed to the office of "Commissary," the function of which was to represent the Bishop of London in the Colony.

Major John Welsh, Justice in 1666, a Commissioner of Anne Arundel County in 1667, and from 1678 to 1679 High Sheriff of Anne Arundel County.

All of the ancestors of William Bowie mentioned in this sketch were residents of the Colony or State of Maryland.

\section{BROWN}

George Edward Brown was born in Boston, Massachusetts, on the 12th of April, I857, and is the son of Benjamin Franklin Brown (an old Boston merchant) and his wife, Augusta Ball Hughes, daughter of the distinguished English sculptor. R. A., who made his home in America for many years, dying in I868. He was the recipient of many honors and medals, both at home and in America, during his active career.

George E. Brown was educated in private and public schools and, owing to ill-health, spent some time in Europe with part of his family, in I875. Upon his return entered a commission house, later, spending some years in the banking business and 
of late years been engaged in the real-estate business, making a specialty of sales and leases in the down-town district.

In most of his lines on the paternal side he traces to the emigrants (the sixth, seventh, and eighth generations:, Especially in the Brown, Coolidge, Newell, Dodge, Porter. Gardner. Dumbar and other lines. He has been a member of many patriotic societies, having held office in all but one or two. He has naturally alwars been interested in the fine arts--for seven or eight members on his mother's side were artists, etc.-and he has been a student of Roman and Greek antiquities, especially engraved gems, having possessed many fine specimens, as well as coins. He has a good collection of prints and some water-colors, as well as other specimens of the arts.

\section{BROWN.}

George Whitfield Brown, banker, was born in the city of Washington, D. C.

He comes of a very ancient family by the name of Bruen, of Bruen Stapleford, of Chester, England, allied to many of tine gentry in England.

George Whitfield Brown was the son of William Van Florn Brown and Adelaide Harrington and grandson of Rer. Obadiah Bruen Brown, who was born in $\mathrm{I} / \mathrm{B}$. o. in Newark. A I. of a family who early came to America. He married Mrs. Jackson. whose maiden name was Elizabeth Reilly. Rer. Obadiah Bruen Brown was great grandson of Tohn Bruen, son of the distinguished Obadiah Bruen. who was before 1650 chosen seven times deputy to the General Court. clerk of Court for Gloucester County, freeman of Plymouth Colony, I640, and 
founder of the town of Guilford, now known as Newark, N. J.

George Whitfield Brown married Mary d'Antignac Cuthbert, descended from the distinguished families of Cuthbert, Fuller, d'Antignac, T'urpin, Ballard, Middleton, Fuller, Barnwell and others, and, besides a daughter, Mrs. Charles Russell Train, has one son, Cuthbert Barnwell Brown, Herald of the Ordar of Washington.

Clthbert Barnwell Browx, born in Washington, D. C., and is the son of George Whitfield Brown and Mary d'Antignac Cuthbert, and, besicles his paternal line, is descended through the maternal line from such ancient families as Cuthbert Barons of Castle Hill and from the Baron d'Antignac, the Turpins of Virginia and Honorable Thomas Ballard, member of the King's Council of Virginia. He also descends fromWilliam Fuller, one of the Lords Proprietors Deputys of South Carolina, and from Col. IVm. Fuller of the Revolutionary period and Lieut. Isaac DuBose, of the Continental Line from South Carolina. He numbers among his illustrious progenitors the Hon. Edward Middleton, Lords Proprietors Deputy, I678, I683, I703, member of the Grand Council and Associate Justice. His son, Hon. Arthur Middleton, also Lords Proprietors Deputy and member of the Grand Council, President of South Carolina Convention I719, President of His Majesty's Council for South Carolina, and Governor of Souti Carolina. His son, Col. Thomas Middleton, member of Commons House of Assembly from I742-I766, Colonel of South Carolina Regiment, who married as his second wife Anne, daughter of Col. Nathaniel Parnwell by Mary, daughter of Col. John Gibbes, son of Governor Robert Gibbes of South Carolina. 
Col. Nathaniel Barnwell, who was a member of the Commons House of Assembly of South Carolina, was the son of the noted Col. John Barnwell, who arrived in South Carolina in I70I from Dublin, Ireland. He was Deputy Secretary of the Colony, Clerk of the Council, Comptroller of the Colony, member of the Commons House of Assembly and of Governor's Council, Deputy Surveyor General, Colonel in Command in an expedition against the Tuscaroras, I7I2, and Yemassee Indians, and Agent of Province of South Carolina in London, England, in I7 I9.

The direct line of descent of Cuthbert Barnwell Brown, son of George Whitfield Brown and Mary d'Antignac Cuthbert is as follows:

Grandson of James Hazzard Cuthbert, D. D., and Julia Elizabeth Turpin, daughter of Dr. William Henry Turpin ard Marie Antoinette d'Antignac, daughter of the Baron d'Antignac and Hannah, daughter of Lieut. Isaac DuBose, a prominent South Carolinian.

Great grandson of Lucius Cuthbert and Charlotte, daughter of Col. Thomas Fuller, and Elizabeth, daughter of Col. Thomas Middleton and Anne Barnwell, daughter of Col. Nathaniel Barnwell and Mary Gibbes, granddaughter of Gov. Robert Gibbes.

Great great grandson of James Hazzard Cuthbert, son of Dr. James Cuthbert and Mary, widow of Edward Wigg and daughter of Col. William Hazzard.

Great great great great grandson of John Cuthbert, Baron of Castle Hill, and Jean Hay, daughter of Right Rev. William Hay, Bishop of Moray.

Crreat great great great great grandson of George Cuthbert, Baron of Castle Hill, and Magdalen, daughter of Sir James Fraser, of Brae.

Col. Thomas Fuller, who married Elizabeth Middleton, was the son of Col. Thomas Fuller and Lydia Hazzard, son of Richard Fuller and Mary Drayton, son of William Fuller, I ords Proprietors Deputy and member of House of Commons of South Carolina April 2, I7 I2. 


\section{DR. THOMAS J. W. BROINA.}

Thomas J. Wilson Brown, born October 2, 1867, in the Talley of the Nola Chucky, about six miles south of Jonesboro. Tennessee; graduated from Washington College (Tennessee) with B. S., May I5, I890, and finished a Latin Scientific Course at the same Institution. May I9. I892; received the degree of II. D. from Columbian Lniversity (now George Washington Lniversity), June 6, I90 I : married Geneviere Arnold, daughter of Judge George Jackson Arnold, of West Tirginia: standard-bearer of the Order of Washington, member of the District of Columbia Society Sons of the American Revolution, and of Benjamin B. French Lodge, No. I5, F. A. A. M., Washington, D. C.

He is the son of John Jacob Brown and Esther Eliza Wilson, a granddaughter of Thomas Embree: the grandson of Byrd Brown, born October 20, I80I, and Louisa Rebecca Sevier, born November 2I, I8I6; the great grandson of Jacob Brown, born August 3, I-6I, and Elizabeth Byrd, born January 28. I 69. a daughter of Col. William Byrd, who built Fort Patrick Henry: the great, great grandson of Jacob Brown, born December II. I736, and Ruth Gordon, born in South Carolina, August 4, I740.

The great grandson of John Sevier, Jr., born June 20, i 766 , and Sophia Garoutte, of Philidelphia, the granddaughter of Antoine Garoutte. born in Marseilles, France, January I9, I695; the great, great grandson of John Sevier, born September 23, I745, and Sarah Hawkins, of Shenandoah County, Virginia; the great, great, great grandson of Talentine Sevier and Joanna Goode, of Baltimore, Maryland.

Talentine Sevier, whose ancestors (Navarre Huguenots) emigrated from France to England, was born in London and came to this country, where he married Joanna Goode of Baltimore and, previous to I 740 , emigrated to the County of Shenandoah, in the colony of Tirginia; his son. John Sevier, who was born September 23, I745, attended school at Freder- 
icksburg and Staunton, and at serenteen narried Sarah Hawkins. He laid out the township of Newmarket in the defence of which he had his first experience in Indian fighting.

Young Sevier's successes attracted the attention of Lord Dunmore, the last of the Royal Goremors of Tirginia, who gave him a commission as Captain in the Tirginia line.

In $17 / 2$ he moved to Wautaga (now Tennessee) with his sons. Toseph, James and John. where, with an organized militia, he fought the Indians for orer twenty rears and aided in building up a Commonwealth.

He was a Colonel at the battle of King's Mountain: was commissioned a brigadier-general in the Lnited States Army: was six times elected Gorernor of Tennessee: and was the first representative in Congress, then in Philadelphia. from the Mississippi Talley.

"Jacob Brown was born in South Carolina. December elerenth. $1 / 36$; settled on Nolichucky in $17 / 2$. purchased land of the Cherokees. He served in the Indian wars, at the head of his Company in Sevier's regiment at King"s Mountain, and then on Arthur Campbell's expedition. He was made a Major: defeated a party of Indians in the fall of $\mathrm{I}-S_{1}$, and died. June twenty-eighth, from an accidental wound receired while out hunting:"

References:

Ramsey's Annals of Temnessee: Rear-Guard of the Rerolution, and John Serier as a Commonwealth-Builder. Gilmore: King"s Mountain and Its Heroes. Draper.

\section{BOITKER.}

Xitchell Harrey Bowker, retired merchant, Whitefield I. H., educated in the public schools of Lunenburg. Tt., Lancaster (N. H.) Academy, and New Hampshire Commercial 
College: enlisted in Company $\mathrm{K}$. 8th Vermont Volunteers, when eighteen years of age, but his father, owing to the fact that he was the only boy in a family of seven children and was needed on the farm, refused to sign the necessary release; two vears later the father finally consented to release him and he enlisterl in Company E. I 5 th Temont Volunteers, but was stricken with typhoid fever while drilling at Island Pond. Termont. and sent home. He married Laura P. Brooks, daughter of Hon. Jonah and Sophronia (Bradford) Brooks, and has two sons. mentioned below: moved to Lisbon, $\lambda$. H., in I86;. where he entered upon a mercantile caresr which he successfully isllowed until his ratirement in IgIO; a republican in politics. he has filled many minor civil offices, including Member of Schiol Board. Moderator cf School Meetings and of Town of Whitefield. the latter for a period of twenty-two vears, and in IR 5-7 was a member of Governor Busiel's Council from the Fifth Councilor District: member of Free UVill Baptist Church of Whitefield: Past Master of Kane Lodge, No. 5.4. F. and A. M. : Past High Priest of Franklin Chapter, Io. 5.R. A. II.: member St. Gerard Commandery, K. T.. and E. A. Raymond Consistory 32 Masons: during his business life of forty-three years, besides being the manager and owner of several large stores in Lisbon and Whitefield, he has been a Director of the Whitefield Savings Bank and Trust Company and the Thitefield Manufacturing Co.: President of the Coos Mining and Development Company and at one time operated a chain of creameries in Lancaster. Whitefield anrl Meredith. N. H.. and Lunenburg. Tt.

Edgar Marshall Bawker. born Lisbon. New Hampshire, April I8. I8-6: is son of Mitchell H. Bowker and Laura P. Brooks: grandson of Roswell Bowker and Jane Blakeslee; son of Levi Bowker and Betsy Silsby: son of Gideon Bowker and Hannah Fletcher: son of Antipas Bowker and Esther Rice; son of Tosiah Bowker and Hazadiah Eagen.

Gideon Bowker served in Wood's Company. Colonel Ward"s Regiment. in I7\%: later in Barnes' Company, Bigelow's Regiment, and Dow's Company. same Regiment, to I -80. 
Ėdmund Bowker, Colonial Ancestor, was member of Artillery Company, Dorchester, Mass., arrived i646.

Edgar Narshall Bowker, lawyer, Whitefield, N. H.; gradwate Whitefield High School and George Washington University Law School; Judge Whitefield Police Court for eleven years; republican; member Whitefield Free Baptist Church; School Board; Moderator School District; Clerk Fire Precinct; Past Master White Mountain Lodge, No. 86, F. anrl A. M.; member North Star Chapter. No. I6, R. A. M., and J. W. of North Star Commandery, K. T.; High Councillor High Court of New Hampshire and Vermont I. O. F.; treasurer Mt. Washington Grange; member County Committee Y. M. C. A.; New Hampshire Chapter Sons American Revolution, and Order of Washington; married Marie Halligan in I904 and has two sons, Bradford and Robert.

Charles Harvey Bowker, physician. Washington, D. C.; born March 20, I870, at Lisbon, N. H.; son of Mitchell H. and Laura P. Bowker, for paternal ancestry see sketch of Mitchell Harvey Bowker ante, on maternal side descends from Governor William Bradford, of the Plymouth Colony; graduate of Lisbon High School, New Hampton Academy; M.D., National University; M. D., Hahnemann Medical College; A. B., George Washington University; post graduate work at New York Post Graduate College, New York University, Harvard University; Interne Ward's Island Hospital, N. Y.; practiced at Berlin, N. H., and held the following positions: City Health Officer, County Physician, Surgeon to Androscoggin Hospital, Boston \& Maine R. R.; International Paper Co. 's Mills: President Berlin Cooperative Store; Treasurer Berlin Pharmacy Company, Secretary-Treasurer Whitefield Publishing Co., etc.; moved to Washington, D. C., where he married Eleanor Thompson-Dyer, I9O3; since moving to Washington, D. C., has held following positions: Surgeon U. S. Coast and Geodetic Survey, Medical Examiner U. S. Pension Bureau, Associate Professor Bacteriology Howard University, Professor Physiology U. S. Teterinary College, Associate Prnfessor Anatomy George Washington University, Professor 
Pathology National University, Captain Medical Corps National Guard, D. C.; member New Hampshire Medical Association, D. C. Medical Society, American Medical Association, Association Military Surgeons, National Geographic Society, Washington Academy of Science, American Association for the Advancement of Science, Association for the Prevention and Cure of Tuberculosis, etc.; Republican, Lutheran, Mason, Odd Fellow, member Order of Washington, Sons of the American Revolution, National Genealogical Society, Home Club, Monday Evening Club, Capitol Yacht Club.

\section{BROOKE.}

Francis John Taliaferro Brooke, son of St. George Tucker Brooke and Mary Harrison Brown, daughter of Thomas Augustus Brown and Ann Steptoe Washington, daughter of Samuel Walter Washington and Louisa Clemson, son of George Steptoe Washington and Lucy Payne, son of Colonel Samu'el Washington and Ann Steptoe, son of Augustine Washington and Mary Ball, son of Lawrence Washington, son of Colonel John Washington.

\section{BURROUGHS.}

William Berrien Burroughs, M. D., was born April 7th, $^{\text {th }}$ I842, at Savannah, Georgia. The history of the family goes 
back to the Elizabethan days of England's glorious marine exploits. An old record names Captain Stephen Burrough: as captain of one of three vessels which attempted to reach China by way of Nova Zembla in I553. Captain Burroughs published a book of his adventures, during which he reached "farthest north" at that time (seventy degrees and three minutes), and was "the first who observed the declination of the magnetic needle." In old books of heraldry is described th: Burroughs coat of arms, and many other records indicate the prominence of the name in England during the sixteenth and seventeenth centuries. Sir John Burroughs, who was knightel in 1624 , was an attendant and court official to King Charles $I$. His descendants have been prominent in England from that time to this, one of them having been in recent years head of the largest drug house in the world at London.

The founder of the family in America was John Burroughs, who was born in Dorsetshire, England, in I6I7. and came to America to Salem, Massachusetts, about 1642. As an adherent of Charles I, he had been one of those who fled from England at the time to escape the religious and political persecution after the dissolution of the long parliament of which he had been a member. Soon after arriving in this country, he located at Long Island, and was one of the original settlers of Middleburg, in 1652 , where he paid his share of the Indian rate. Being a leading man and skillful penman, he served as town clerk and clerk of court, and made the first map of Newtown. He was one of the seven patentees of Newtown, in I666, and continued in office as town clerk until his death, when his oldest son succeeded him to that office. His children, grandchildren and great grand children moved to New York. New Jersey, Pennsylvania and Connecticut.

Fourth in descent from this noted founder of the family in America was Benjamin Burroughs, grandfather of Dr. Burroughs. Benjamin Burroughs was born on Long Island at Newtown, March 3Ist, I779, and died at Savannah, Georgia, April I4th, 1827 . In I795 he brought the name south to Augusta, Georgia, and in the following year moved to Savannais. 
On July 2nd, I799, at the age of twenty, he married in Savannah Miss Catherine Eirick, daughter of Alexander Eirick, d member of the colonial parliament.

Grandfather Beniamin Burroughs was prominent as a cotton and commission merchant in Savannah. His partner, Mr. Oliver Sturges, and himself, owned a third interest in the steamship Savannah which, in I8Ig, was the first vessel to cross the Atlantic Ocean under her own steam. The partners shipped a large cargo of cotton to Liverpool on the first voyage of the Savannah, May 26th, I8I9, and reached Liverpool after a passage of twenty-five days, during which the engine was employed eighteen days. Benjamin Burroughs was an elder in the Independent Presbyterian Church in Savannah, and gave five thousand dollars to assist in building the church in 1817 .

Joseph Hallett Burroughs, father of 'Dr. Burroughs of Brunswick, was born in Savannah, Georgia, June 3 rd, I803. On June 26th, I828, he married Miss Valeria Gibbons Berrien, who was born in Savannah August 4th, I806. Her family was specially distinguished. She was the daughter of John Macpherson Berrien and Eliza Anciaux. Eliza Anciaux's father was Nicholas Anciaux, quartermaster-treasurer of the French Royal Deux Ponts Regiment, and was present at the surrender of Lord Cornwallis. His commission, signed by Louis XVI, is now in the possession of Dr. Burroughs at Brunswick, Creorgia.

Grandfather Berrien was the son of Major John Berrien, brigade-major of General Lachlan McIntosh's brigade in the Revolutionary War. His father was Judge John Berrien of the Supreme Court of Judicature in New Jersey Colony (Nova Caesaria). Najor John Berrien married Miss Margaret Macpherson of Philadelphia. She was a daughter of Capt. John Macpherson, an officer in the provincial navy, the Macpherson family having been especially prominent in miliitary affairs during the Revolutionary War. Grandfather John Macpherson Berrien was U. S. Senator eighteen years. In January, I820, in debate of his celebrated tariff protest 
effort, the summit of his oratorical fame was reached and he was saluted as the American Cicero.

He was Attorney General in President Jackson's Cabinet, and declined the mission to England on account of domestic affliction.

Joseph Hallett Burroughs was the father of Dr. Burroughs; was a successful factor and commission merchant in Savannain, Ceorgia. He served as paymaster of the First Regiment of Georgia Militia, and was a member of the Presbyterian Church. He died in Savannah in 1854 .

Dr. W. B. Burroughs, our subject, comes of a family of physicians. His oldest brother, Dr. R. B. Burroughs, late surgeon of S. A. L. Railroad, was President of the Florida Medical Society, and his youngest brother, Dr. Charles J. Burroughs, late Health Officer of Jacksonville, and President of the Jacksonville Medical Society. Another brother, John W. Burroughs, is a practicing lawyer of Savannah, Ga. Dr. Henry Kollock Burroughs was for many years Mayor of Savannah, Ga. Our subject received his primary education at the Chatham Academy in Savannah and was in the Junior Class at Oglethorpe University, near Milledgeville, then the capital of Georgia, when war's rude shock closed its doors. The students formed a Company and elected officers and then transferred themselves from the peaceful joys of the old Campus to the bloody fields of battle. The University, like thousands of valuable buildings, was destroyed by Sherman's army.

Our subject joined afterwards the Randolph Rangers, which became a part of the 7th Georgia Cavalry, Young's Brigade, Hampton's Division, Army of Northern Virginia. He served all through the war, participating in the battles at Borden's Plank Road, Dinwiddie Courthouse, Stony Creek and other points, and received his parole at Appomattox.

Our subject graduated in medicine at the Savannah Medical College in March, 1867. For fifteen years he engaged in the active practice of his profession in Camden County, Georgia, and accumulated a considerable fortune by his professional services. His health failed, and in $188 \mathrm{I}$ he moved to Brunswick. 
Dr. Burroughs for fifteen years has been vice-president of the Georgia State Agricultural Society, and for twelve years has been president of the Brunswick Agricultural Society. He has held a directorship in the National Bank of Brunswick, in the Brunswick Savings \& Trust Company, in the Kennon Cotton Factory, in the Board of Trade, and Chairman of Statistics in the latter body. He is Grand Vice-Chancellor of the Knights of Pythias of Georgia. Dr. Burroughs was appointed by Gov. Northern delegate to the National Nicaragua Convention which assembled in New Orleans in 1893, and in St. I,ouis in I892, and at each convention was elected an executive committeeman for his State by the Georgia delegation. For five years he has been Lieutenant Governor of the Society of Colonial Wars of Georgia. He was director and superintendent of the department of education at the Georgia State Fairs held in different towns in the State of Georgia, and was appointed by Governor Joseph M. Terrell, of Georgia, to the office of director of history and made exhibits at Jamestown in 1907. Dr. Burroughs has made many historical contributions to current periodicals on cotton and on the early history of Georgia.

Dr. Burroughs was reared in the Presbyterian faith, and now attends all denominations. He has served eight years as a member of the Brunswick Board of Education. On January 17,1872 , he was married at Waynesville, in Wayne County, Georgia, to Miss Elizabeth Pettingill Wilson Hazlehurst, oldest daughter of Maj. Leighton Wilson Hazlehurst and Mary J. McNish, of Savannah. Her father was a wealthy rice planter of the Satilla river, and during the war between the States was commissioned Major of the Fourth Georgia Cavalry. Major Hazlehurst was a son of Robert Hazlehurst, of Charleston, Sotth Carolina. The children of Dr. Burroughs and wife are mentioned as follows: Mary McNish Burroughs, born in Camden County, Georgia, married Charles Walter Deming, who is in the oil and real estate business at Tulsa, Oklahoma; Lilla Hazlehurst Burroughs, born in Camden County, Georgia, and unmarried; Josephine Hallett 
Burroughs, born in Camden County, Georgia, married Captain Clyde A. Taylor, who commands the Brunswick Riflemen of the National Guard, children Clyde A. Taylor, Jr., and Lilla Hazlehurs,t Taylor; William Berrien, Jr., born in Camden County, Georgia, married Ida D. Hartfelder, of Elizabeth, New Jersey; Leighton Hazlehurst Burroughs, born in Brunswick, unmarried; Mac Hazlehurst Burroughs, born in Brunswick, married Miss Eliza F. McIntosh, of McIntosh County, Geor ria, now resides in Dublin, Georgia.

\section{BULLOCH.}

Dr. Joseph Gaston Baillie Bulloch was born in Roswell, Cobb County, Georgia, October 12, I852, and is the son of the late distinguished physician and surgeon, Dr. William Gaston Bulloch, and Mary Eliza Adams Lewis, both natives of Savannah, Georgia. Dr. J. G. B. Bulloch was brought up at his home in Savannah, Georgia, and attended the schools in that city, thence went to Yorkville Military School, Yorkville, S. C., thence to Bryant Stratton's and Sadler's Business College. Baltimore, Maryland, and graduated from the South Carolina Nedical College, Charleston, South Carolina, on March 7 , I877, having attended his first course at the Savannah Medical College which, owing to the yellow fever epidemic in 1876 , had to suspend. At the breaking out of the yellow fever epidemic in 1876 in Savannah, although only a medical student, he volunteered and served for a time in the Savannah Hospital, administering medicine and attending, under the House Physician, the sufferers in that notable epidemic. He subsequently went to Florida, where he practiced his profession at 
Hawthorn, Palatka and Newnansville. Smallpox having broken out in Palatka, it became necessary to have one to take charge, and he was, therefore, made a member of the Board of Health for Putnam County, Florida, Health Officer of the City and then of the County.

Being a member of the American Public Health Association, he attended a meeting in Indianapolis, Indiana, where he was made a member pro tem. of Executive Committee of that Association. In 1883 the Governor of Florida commissioned Dr. Hargis and Dr. Bulloch to represent the State of Florida at a meeting to be held in Detroit, Michigan. Having gone back to his home, Savannah, Georgia, he stood a Civil Service examination for the position of Physician in the Indian Service and passed the examination, being one of the seven who received an appointment out of ten who passed, out of forty applicants. In 1895 he received the appointment as Sanitary Inspector in Marine Hospital Service and boarded the Revenue Cutter Forward for the purpose of patrolling the Gulf Coast looking out for yellow fever infected vessels. In the fall of same year he received the appointment of Physician to Pima Indian Agency in Arizona, and after remaining there about eighteen months he was by Civil Service transferred to Marine Hospital Service and sent to Gulf Quarantine Station, Biloxi, Mississippi, where he was one of the acting Assistant Surgeons at that station. Later he was reinstated in the Indian Service and went to Oneida, Wisconsin, where he was Physician to Oneida Indian Industrial School and to the Episcopal Hospital and Oneida Indians. From there he was sent to Cheyenne Agency, South Dakota, where he was the Physician to the School and assisted in attending the Indians on the Reservation. From thence he went to the Cherokee Indian S.chool in Swain County, N. C., attending the school children and the Indians on the Reservation. From Cherokee he went to Washington, D. C., to the Pension Bureau, where he rose to be a Medical Examiner.

As a physician he was well known and quite a successful practitioner and as a surgeon performed the following opera- 
tions; amputation of arm at shoulder joint, leg, thigh, part of foot, and other operations of less import. As an oculist he performed an operation for cataract and for ptosis of eyelicis successfully and had success in treating diseases of the eye.

While in the Indian Service he was several times designated to preside over the Physicians' Conference in Indian Service, when the Indian Department had their meetings with the $\mathrm{Na}$ tional Educational Association. Although as a separate body, he presided for the Superintendent of Indian Schools at the meeting held in Charleston, S. C. He was elected President of the Indian Medical Saciety at Colorado Springs during a meating of the physicians attending the Indian Branch of the National Educational Association.

While living in Savannah he assisted his father as physician to Georgia Infirmary, Chatham County Jail and the Convict Camp, and, besides the practice of medicine, has held many positions in patriotic and other societies and has been well known as an author on genealogical, medical and sanitary articles and other different writings. The following positions have been held by him and the subjoined list of books and articles published.

MEDICAL.

Ex-Recording Secretary and Librarian Georgia Medical Society.

Ex-Member of Florida State Medical Society.

Ex-Member and one of Founders of Alachua County Medical Society, Florida.

Fx-Member and one of Founders of Putnam County Medical Society, Florida.

Ex-Member of Arizona Medical Territorial Association.

Ex-Member American Public Health Association and memher of Executive Council pro tem. meeting Indianapolis, Ind.

President Indian Medical Society.

HISTORICAL.

Ex-Member Georgia Historical Society.

Ex-Member South Carolina Historical Society.

Member Huguenot Society of South Carolina. 


\section{ECCLESIASTICAL.}

Member of Brotherhood of St. Andrew, St. John's Church, Washington, and Ex-Member Executive Committee of Local Assembly, D. C.

Ex-President Orange Creek Benevolent Association, Fla. GENEALOGICAL.

One of the Founders and Ex-President of National Genealogical Society and now Vice President; Honorary member California Genealogical Society.

\section{MILITARY.}

Ex-Member Savannah (Ga.) Cadets.

Patriotic and Hereditary Orders and Societies.

Ex-Chancellor Aryan Order.

Ex-Vice President and Registrar and one of Founders of Sons of Revolution, State of Georgia.

President of Sons of Revolution of Florida.

One of Founders of Order of White Crane.

One of Founders of revived "Knights of Golden Horse Shoe."

One of Founders of Order of Washington and Chancellor and Historian General of same.

One of Founders of Imperial Order of the Yellow Rose and Chief Regent.

Ex-Member General Society of I8I2, Philadelphia, Pa.

Member of Order of Runnemede.

One of Vice Presidents of Colonial Lords of Manors.

Author of the Foliowing Genealogical Works.

I A History and Genealogy of the Bulloch Family and Connections.

2 A History and Genealogy of the Families of Bellinger and DeVeaux and other Southern Families.

3 A History and Genealogy of the Habersham and other Southern Families.

4 A History of the Stewart, Elliott and Dunwoody Families. 
5 A History and Genealogy of the Family of Baillie of Dunain.

6 A Biographical Sketch of Hon. Archibald Bulloch.

7 The Cuthberts, Barons of Castle Hill, and their descendants in South Carolina and Georgia.

8 A History and Genealogy of the Family of Bulloch Stobo and Irvine Cults.

9 A History and Genealogy of the Robert Family of South Carolina.

Io A History of the Glen Family of South Carolina and Georgia.

\section{ADDRESSES AND ARTICLES.}

The Study of Genealogy.

Address Before Order of Washington on the First Anniversary.

Address Before the Order of Washington "Can the Order of Washington Be A Factor In the Promotion of A Universal Brotherhood?"

Address Before the Order of Washington on its Presentation of the Standard to Order.

Address at Falls Church, Va., on Presentation of Vases in Memory of Hon. Hugh V. Washington.

Address before D. A. R. Congress on Presentation of Bust of Hon. Hugh V. Washington.

Speech at Banquet of Sons of Revolution of Georgia, giving a history of foundation of that Society in Georgia.

Address before the National Genealogical Society on The Scotch in America.

Address before the National Genealogical Society on "The Problems Which Now Confront Us."

Memorial Day Speech, Oneida, Wisconsin, i898-9.

“The Indian Question," newspaper article.

“The Negro Question,” newspaper article.

"A Proposed Form of Government for the Philippines."

"A Proposed Form of Government for Cuba" (newspaper.)

"Are We Anglo-Saxons?" (newspaper.)

"The Scots in Georgia." 
"The Scots in South Carolina." Aberdeen, Scntland, Weekly Journal.

"A Study of Eugenics."

STORIES.

Knights of the Golden Cross, publisined.

A Tale of Georgia's Hero.

The following medical articles have been written and published:

"Should we have a Bureau of Health?" Va. Med. SemiMontinly, Igo8.

"A Bureau of Health." Va. Med. Semi-Monthly, igio.

"The Medical Inspection of Schools," Va. Med. SemiMonthly, igio.

"Should the Physician be Educated?" Va. Med. SemiMonthly, I9I I.

"Can There be Peace?" The New Albany, Ind., Med. Herald, igri.

"We Can Not Stop the Ravages of Tuberculosis, unless?" The New Albany, Ind Medical Herald, I9I I.

"We Can Not Stop the Ravages of Tuberculosis," The Medical Council, Philadelphia, Pa., I910. The Cause of Disease.

"Aestivo Autumnal Fever," The Medical Council, Philadelphia, Pa., I9I4.

"Is The Specialist Thoroughly Equipped?" New Albany, Medical Herald, igr2.

"Hemorrhage And Its Differential Diagnosis," Arizona Med. Association, I 897 .

Sanitary Problems, The Therapeutic Record, I9I4.

"The Treatment of Pneumonia," The Therapeutic Record, I9I4.

"War and Disease," The 'Therapeutic Record, Louisville, Ky., I914.

"Shall We Commit Abortion?" The American Journal of Chemical Medicine, Chicago, Ill., I9ro.

"Give Us Air," The American Journal of Clinical Medicine, Chicago, Ill., I9Io. 
"We Should Have a Department of Health," The American Journal of Clinical Medicine, Chicago, I1l., I9I I.

"Therapeutic Nihilism," The American Journal of Chemical Medicine, Chicago, I11., I9II.

"The Differential Diagnosis of Semi-Tropical and Tropical Diseases," The Medical Council, Philadelphia, Pa., I9I 5.

He has held the following positions:

Sanitary, Inspector Marine Hospital Service; Acting Assistant Surgeon Gulf Quarantine Station, Mississippi, M. H. S; and Agency Physician, Pima Agency, Arizona; Indian Service, Physician to Oneida Indian School and Oneida Indians, Oneida U. S. Indian Service; Physician to Cheyenne Agency Industrial School and assisted in attending Sioux Indians on Reservation; Indian Service Physician to Cherokee Indian School, Cherokee, Swain County, N. C., and to Cherokee Indians: Acting Chairman for Superintendent at Indian Division of N. E. A. Assn., Charleston, S. C. ; Medical Examiner Pension Office; President of Indian Medical Society; Recording Secretary and Librarian Georgia Medical Society, Savannah, Ga.; Member of Arizona Medical Association; Member Florida State Medical Society; Member American Public Health Association and member pro tem. of Executive Board at meeting of Association in Indianapolis, Ind.; appointed by Governor of Florida with Dr. Hargis to represent the State at meeting of American Public Health Association to convene in Detroit, Mich., I883; Health Officer of Palatka, Fla., when they had an epidemic of smallpox; Member of Board of Health of Putnam County, and Health Officer of County; Member of Georgia Historical Society, Savannah, Ga.; Member of South Carolina Historical Society, Charleston, S. C.; Member of Huguenot Society of South Carolina; one of the organizers of Sons of Revolution in State of Georgia and Vice President and Registrar of same; one of organizers Florida State Society, Sons of Revolution, and President of same.

Dr. J. G. B. Bulloch is the son of the late distinguished physician and surgaon, Dr. William Gaston Bulloch, of Savannah, 
Georgia, and his wife, Mary Eliza Adams Lewis (see Lewis).

He was married April 15, I880, by Rev. Mr. Pooser at the residence of Walter Bailey, Esq., Kershaw County, South Carolina, to Eunice Helena Bailey, daughter of Charles Bailey, Esq., and Ann Cloud, descended from the ancient families of Bailey, Gerard and Beckwith of Connecticut and the Cloud family of Pennsylvania and South Carolina.

Issue: I. Archibald Irvine DeVeaux Bulloch, took the prize of $\$ 25$ at the State Fair in Savannah for the best oration in his Class and the Harper's Scholarship in Freshman Class at the University of South Carolina, Columbia, S. C. He entered George Washington University and was doing finely in his studies when stricken with the grip which developed into diabetes mellitus, from which he in a few years dieci

II. William Gaston Glen Bulloch, a companion of Order of Washington, prize man in Strong's Military School, Savannah, Ga., for which he received a beautiful gold medal, having stood all around as head of Class; graduate of Bliss Electric School.

III. Douglas Eugene St. Clond Bulloch, prize for mathematics, Strong's School; graduate Central High School, Washington, D. C.

\section{THE BULLOCHS OF GEORGIA.}

The Bullochs of Georgia ciaim descent from Sir Donald Balloch, son of John Mor Tanaister Macdonald, son of John Macdonald, Lord of the Isles, who married Lady Margaret Stewart, daughter of King Robert II.

The first Bulloch in America was the Honorable James Bulloch, who went from Scotland to South Carolina about 
the year I729, and, as the cradle of the Sept was at Baldernock, the tradition that he was from Glasgow is presumably correct. James Bulloch held many positions during Colonial days, and we find him filling the following places: King's Justice of the Peace in Colleton County, South Carolina, I735 and I737; Special Agent under the great seal to the Creek Indians; member of the House of Commons of South Carolina, I754, and in Georgia; Justice of the Peace May Iо, I764, and October, I767, for Christ Church Parish and member of the Provincial Congress of 1775 and a Captain of the Sea Island Company. He received several grants of land and was, when he went to Georgia, a planter in South Carolina.

He married first Jean Stobo, daughter of the Rev. Archibald Stobo, a prominent minister in South Carolina, who was a graduate of the University of Edinburgh, June 25, 1697. On September I, I705, Rev. Archibald Stobo granted a factory to Alexander Brown, merchant in Edinburgh, Scotland, to collect all debts due him, said factory, being dated at Charleston, S. C. Rev. Archibald Stobo married Elizabeth Park, daughter of James Park, writer in Edinburgh.

James Bulloch and Jean Stobo had, among others, one son, Hon. Archibald Bulloch, who held many positions in Georgia, such as Speaker of the Colonial Legislature, President of Provincial Congress and President and Commander-in-Chief of Georgia I776-77. He married Mary, daughter of the Hon. Colonel James DeVeaux, Senior Justice of King's Court in Georgia I760 and member of the Provincial Congress of I775, who married Ann Fairchild, daughter of Richard Fairchild and Anne, daughter of Edmund Bellinger, first Landgrave of the name and one of the Colonial Nobility of South Carolina. Edmund Bellinger held many honorable positions during the Colonial period of South Carolina.

Hon. Archibald Bulloch and Mary DeVeaux had an elder son, Captain James Bulloch, Jr., member of the Virginia State Garrison troops raised for State defense, Col. George Muter. James Bulloch, enlisted in 1778 and was honorably retired in I78I, returning to Georgia he was commissioned a Captain 
in Indian War. He was Clerk of the Superior and Inferior Courts of Georgia and was made an honorary member for life of the Georgia State Society of the Cincinnati for his honorable record in the service of his country.

He married Ann Irrine, daughter of Dr. John Irvine, who had left Scotland and gone to Georgia and who was the son of Charles Irvine, Laird of Cults. a cadet of the noble Baronial family of Irrine of Drum. Charles Irvine had married Euphemia Douglas, daughter of John Douglas, Laird of Tilquhillic, an ancient family allied to many of the noble families of Scotland. Dr. John Irrine practised his profession in Georgia. and was a Justice of the Peace in $17 \sigma_{4}$ in St John's Parish, and Justice of the Peace, of the Parish St. John. I 768 , and Norember, I7 I, and member of the last Royal Assembly in Georgia. in $\mathrm{I}$-80. He married Ann Elizabeth Baillie, daughter of Col. Kenneth Baillie, who is found in Georgia as early as I735 and was of the ancient family of Baillie of Dunain. Scotland.

Captain James Bulloch and Ann Irvine had: John Irvine Bulloch, Maj. James Stephens Bulloch, the grandfather of Col. Theodore Rooserelt, and Jane Bulloch, who married John Dunwoody, Esq.. of Liberty County, Georgia, son of Dr. James Dunwoody, member of the first Executive Council in Georgia, as a free State, and one of the first phrsicians to practice medicine in Libertycounty, Georgia, who went to Georgia about I 7 ; 0 from Pennsyluania, who was the son of John Dunwordy of Londonderry, Ireland. who went to Pennsylvania about I730. John Dunwoody and Jane Bulloch had, among others. a son. Maj. John Dunwoody, of the Mexican and Civil wars, who was the father of the late Maj. Jefferson D. Dunwoody our late deceased member.

John Irvine Bulloch, attorner at law. Clerk of the Federal Court. eldest son of Capt. James Bulloch. and Anne Irrine married Charlotte Glen, daughter of Chief Justice John Glen. of Georgia, I; -6-78. Mayor of Savannah, etc.. who married Sarah Jones, daughter of Dr. Noble Wimberley Jones, one of the most prominent patriots of the Revolutionary War, who had been Speaker of the Royal Colonial I,egislature and an 
officer in Colonial troops, but who, upon the breaking out of hostilities, espoused the cause of the Colonies. His father, Hon. Noble Jones, the friend of Oglethorpe, had left Lambeth County, Surrey, England, and accompanied General Oglethorpe to Georgia in I733. Holding many responsible positions, we find him as one of assistants to the President of the Colony, member of His Majesty's Council, Colonel of Colonial Troops, Judge of General Court and Treasurer of Province, Conservator of Peace, Nov. 7, I732, Recorder, Nov. 8, I732. He married, according to the belief of Capt. Douglas Wimberley, of the 79 Cameron Highlanders, Miss Wimberley, of ancient family. The Jones's were of Welsh lineage and allied to the nobility of Wales, as attested by the coat of arms borne by them.

Dr. Noble Wimberley Jones married Salrah Davis; the daughter of John Davis, Esq., planter, and Theodore Cook, of St. Philips Parish, in Georgia, who left South Carolina and removed to Georgia in I749. He held the position in Colonial days of Surveyor of Roads for Skidaway Island, I754, and had a grant of 500 acres, Island of Skidaway, St. Philip's Parish.

Judge John Glen was the son of William Glen of Wappoo plantation near Charleston, South Carolina, a citizen of prominence in the Colony. who held the following positions: "Commissioner of Work House, one of the founders of Charleston Library and an eminent merchant," and who received a grant of land in I738. He married Ann Alrich, the granddaughter of Hon. Peter Alrich or Alricks, one of the very prominent citizens of Newcastle, Delaware, whose wife was Maria Wessels, of New York.

John Irvine Bulloch and Charlotte Glen had an only surviving son, the late Dr. William Gaston Bulloch, a distinguished plysician, surgeon and oculist of Savannah, Georgia. He married Mary Eliza Adams Lewis, the daughter of John Lewis, Esq., a prominent citizen of Savannah, Georgia, who was the son of Joseph Lewis and Susannah Baker, son of Isaac L.ewis and Susan Kirkland, son of Mr. Samuel Lewis, Sr., 
who held the Colonial position of tax assessor and collector, March 27, I759, for St. Andrew's Parish, and had a grant of $45^{\circ}$ acres of land on the Altamaha River in $175^{8}$.

The Lewis family were early settlers in Georgia and were among her leading citizens, holding different positions of prominence, and by tradition connected to the Washington family of Virginia.

John Lewis married as his second wife Margarat King, widow of Joseph King, and daughter of Nathaniel Adams, Esq., planter, of White Bluff, near Savannah, Ga., who at one time was a Justice of the Peace and had been elected to the Legislature in Georgia, but did not serve. He was the son of Nathaniel Adams of St. Helena, South Carolina, and Margaret, daughter of Edmund Ellis, Esq., who received a grant of a town lot II6, in Beaufort, S. C., July 25 I7I7, son of David Adams and Elizabeth Capers, daughter of Richard Capers, of South Carolina. planter,who died before February, I7 IO-I I, and David Adams, who was of Charlestown, Mass., born I682, was the son of Nathaniel Adams of Boston, Mass., born r653, died Charlestown, I7IO, who married Hannah, daughter of Nicholas Wilmot. A Nathaniel Adams, considered of this line, was a soldier in Philip's War. The last Nathaniel was son of Nathaniel Adams and Mary, born I630, died I69o, son of Nathaniel Adams and Sarah.

Nathaniel Adams, of White Bluff, in Georgia, was born December 20, I747, on St. Helena Island, S. C., and died in Georgia, March 7, I806. He married Anne Bolton, daughter of Robert Polton, brother of Mary, wife of Hon. James Habersham, Governor of Georgia. Robert Bolton married Susannah Nauve, born I727, daughter of Matthew Mauve of Vevay, Switzerland, who was in Georgia in 1740 and held the official position of Commissioner or Surveyor of Roads, March 6, I766, died I775, and had a grant of land of 300 acres in I753. His wife was Jane, of Berne, Switzerland, who died in Georgia, I762. The name Mauves is listed among the Franch nobility. Robert Bolton emigrated to Georgia about I740 and held the following positions: Collector of Taxes, Inspector of 
Leather, Armourer, Commissioner of Work House, I754, Messenger, first Post Master of Savannah.

He was the son of Robert Bolton, Esq., a prominent citizen of Philadelphia, Pa., who was Vestryman and Church Warden of Cirrist Church, Philadelphia, Pa., who went to that Colony from Sheffield, York County, England, in I7ig. He married Ann Clay, widow of Robert Clay, and daughter of Winlock Curtis, and Anne Bowers, daughter of Benanuel Bowers, landowner in Charlestown, Mass., who married, December 9, I653, Elizabeth, cousin of Henry Dunster, first President of Harvard College. Benanuel Bowers was son of George Bowers, of Scituate, Mass., I637, Plymouth, I639, who was a landowner, and who died 1656.

Elizabeth Dunster was baptised July I5, 1632, and was the daughter of Henry Dunster, baptised April 30, I592, and is called of Elton. He married, October Io, I6I5, Isabel Kaye. Henry Dunster was the son of Henry Dunster, born about I560, sometimes called of Elton, in Register, who was probably either son of Robert Dunster, of Tottington, who died in I 599, or of Henry Dunster, Sr., who was born April I I, I592.

Winlock Curtis was the son of Hon. John Curtis, who held the following positions: Justice of the Peace for Kent County, Pa., 25, 7 mo., I685, member of Provincial Council for Kent County, February 2, I689. His other son. Jehu Curtis, was second Judge of Supreme Court.

Dr. William Gaston Bulloch and Mary Eliza Adams Lewis had six children, of whom only three survived.

I. J. G. B. Bulloch, M. D.

II. Robert Hutchison Bulloch.

III. Emma Hamilton Bulloch, poet, member of Colonial Dames of Georgia ; Order of the Crown, and member of Order of Yellow Rose.

NoTF.-For further lineage of the Boltons, see article McBryde, by Professor John McLaren McBryde.

Mrs. M. E. A. Bulloch was a writer of poetry and member of the Colonial Dames and Order of the Crown. 
Robert Hutchison Bulloch was born in Roswell, Cobb County, Ga., on September $\mathrm{I}_{5}, 1854$, and is the son of Dr. William Gaston Bulloch and Mary Eliza Adams Lewis and brother of Dr. J. G. B. Bulloch. After attending school in Savannah, his home, he went to Yorkville Military School, Yorkville, South Carolina, thence to the University of the South. Sewanee, Tenn., thence to the University of Virginia, where he graduated in applied mathematics. After graduation he went on a railroad survey in South Carolina, thence back to Savannah. Besides being in the office of several architects, notably with that prominent one, G. E. Harney, for five years in New York City, N. Y., and also as draughtsman with the Plant System of Railroads, he at last entered into the employ of the Atlantic Coast Line and now lives in Wilmington, N. C.

\section{CAMPBELL.}

John D. Campbell, banker, born in Cleveland, Ohio, July 27, I859, son of James B. Campbell and Margaret L. Campbell, son of Thomas Campbell and Mary Beelman, son of Thomas Campbell and Isabella Lusk Campbell, son of John Campbell, who served during the French and Indian War. His son. Thomas, was Captain Pennsylvania Revolutionary War: member Society Cincinnati, \&c.

\section{CAPP.}

Seth Bunker Capp, of Philadelphia and Devon, Pa., was born in Philadelphia May 23rd, I875. He is the son of 
William Musser Capp, M. D., and his wife Ida Estelle Stitt of Philadelphia, residence Devon, Pa.; a sister (Estelle) Mrs. Frederick Jost, and her son, Gordon Jost, all born in Philadelphia and reside there. Mr. Capp was educated at Delancey School, Philadelphia, Class of I893. He is a member of Old Christ Episcopal Church, where is preserved the pew which was occupied by Washington and his family when Philadelphia was the National Capital. Mr. Capp's first English Ancestor in America was John Howland, a Mayflower passenger. He likewise descends from Henry de Bohun, Earl of Hereford, one of the English Magna Charta Barons. Mr. Capp's French descent is from the Bunkers of Bunker Hill, George Bunker, I632, a son of William (Bon Coeur) a French Huguenot.

Through Major James Stitt he claims Scotch-Irish descent. James Stitt, the first in America, was a Major in the English army, but owing to his sympathy with the Cause, afterwards represented by the unfortunate Emmett, he sailed with two others in his own sloop about I770 and settled finally at Pittstown, N. Y. The Capp family were Scottish and trace their origin and coat of arms back to the days of Bruce. Owing to religious differences they fled to the Palatinate and became Germanized, and emigrated with the great number of Germans who reached this country about I732, and first went to New York, thence to Pennsylvania, preferring the peacful methods of William Penn.

Mr. Capp has lived abroad for a number of years, calling Paris, France, his home. Quite recently he has been in the West; always, however, retaining a residence and interest in Philadelphia. Mr. Capp has become an expert in antiques and possesses for his own pleasure a very worthy collection. He has always been deeply interested in the advancement of Art, Culture and Science. The attached list of Memberships will show far better than any words his comprehensive interest and active participation in promoting these objects. 


\section{MEMBERSHIP OF SETH BUNKER CAPP.}

\section{LIFE MEMBERSHIPS.}

The Fellowship of the Penna. Academy of the Fine Arts.

Pennsylvania Academy of the Fine Arts.

Pennsylvania Horticultural Society.

Pennsylvania State Branch of the National Conservation Ass'n.

Pennsylvania Museum and School of Industrial Art.

Pennsylvania Society to Protect Children from Cruelty.

Pennsylvania Society for the Prevention of Cruelty to Animals.

Pennsylvania Forestry Association.

The American Forestry Association.

The American Association for the Advancement of Science.

The American Economic Association. Christ Church Historical Association.

The American Nature Study Society. Christ Church Historical Society.

The American Dialect Society.

The American Folk-Lore Society.

The American Historical Association.

The Historical Society of Pennsylvania.

The New England Historic Genealogical Society.

The Nantucket Historical Association.

The Franklin Institute of the State of Pennsylvania.

The German Society of Pennsylvania.

The Spring Garden Institute.

The Genealogical Society of Pennsylvania.

The Academy of Natural Sciences of Philadelphia.

The Zoological Society of Philadelphia.

The Photographic Society of Philadelphia.

The National Geographic Society.

The Geographic Society of Philadelphia.

The City History Society of Philadelphia.

The City Parks Association.

The Playgrounds Association of Philadelphia.

The Public Education Association of Philadelphia.

The Fairmount Park Art Association. 
The Fairmount Park Art Association, City Branch.

The Mercantile Library Co.

The Protestant Episcopal Church. (Christ Church, Philadelphia, Pa.)

\section{HEREDITARY ORGANIZATIONS.}

The Society of Mayflower Descendants.

The Society of the War of I8I2 in the Commonwealth of Pennsylvania.

The Pennsylvania German Society.

Sons of the American Revolution.

Huguenot Society of America.

Baronial Order of Runnemede.

The Colonial Society of Penna.

The Pennsylvania Society of Sons of the Revolution.

ANNUAL MEMBERSHIP.

Fraternal, Organizations.

The Order of Ancient Free and Accepted Masons, North Short Lodge No. 937.

The Chapter R. A. M., Loyal Chapter No. 233.

The Council R. \& S. M., Chicago Council No. 4.

The Commandery K. T., Lincoln Park Commandery No. 64. The Oriental Consistory, S. P. R. S. 32 Degree, Valley of Chicago.

The Ancient Arabic Order Nobles of the Mystic Shrine, Medina T'emple.

The Grotto M. O. V. P. E. R., Aryan Grotto No. I8.

The Sword of Bunker Hill, Lincoln Order No. 2.

The Loyal Order of Moose, P A D Chicago Lodge No. 43.

\section{Clubs.}

The Merion Cricket Club (Proprietary Member)

The American Kennel Club.

The Bay Head Yacht Club.

Union League of Philadelphia. 
Contentions, Eitc., Etc., Annual Member.

The National Conference on City Planning.

The National Civic Federation.

The National League for the Protection of the Family.

The Philadelphia Library Company.

The Pennsylvania Society in Chicago.

The DeLancey Alumni Association.

Complimentary Annual Member.

The National Conservation Association.

SINGER.

I. Seth Bunker Capp, born Philadelphia, May 23, 1875 .

2. William Musser Capp, M. D., Philadelphia, born January 22, I842, married November 4, I868, Ida Estelle Stitt.

3. John Charles Capp, born Harrisburg, June 26, I800, died Philadelphia, March 3, I876, married Sarah Singer, born February I3, I829.

4. John Singer, born Lancaster, March I I, I763, died Philadelphia, May I3, I829, married June 21, I793, Anna Maria Musser.

John Singer took an active part in the American Revolution. When but little over I 3 vears of age he determined to enter the army. He feared rejection at home on account of his youth, so tramped to Philadelphia, where he was accepted as a drummer boy in Captain Graff's Company. Tradition says that once on march he was too tired to walk, so he was borne on strong shoulders, while he still kept the soldiers in step by the beat of his drum. A painting representing this 
episode was exhibited some years ago. John Singer was mustered in at Philadelphia, July ıо, I776. (See Penn. Archives, 5th Series, Vol. VII, p. Io72.) He, with others, was taken prisoner and held on the prison ship Jersey in New York harbor, but escaped and enlisted as a private, August 24, I778, in Third Battalion Lancaster Company, commanded by Colonel Alexander I.owry in Captain Robert McKees' Company. (See Muster Rolls, p. 202, Penn. Archives, 5th Series, Vol. VII.) Owing to various reformations we find him on return of I.ancaster troops in Battalion 7th, under Captain Andrew Scott, in October, I78I. (See Penn. Archives, 5th Series, Vol. VII, pp. 703, 722.)

5. Casper Singer, Jr., born October 6, I738, died February 24, I797, married August 10, I759, Eva Maria Spangler.

6. Casper Singer, died March II, I759, married January, I726, Anna Marguretha.

Casper Singer and his wife came from Alsace and, having means, purchased property near Lancaster, Pa. He was granted lands in Hanover County prior to I 734 .

\section{MUSSER.}

I. Seth Bunker Capp, born Philadelphia, May 23, I875.

2. William Musser Capp, M. D., born Philadelphia, January 22, I842, married, November 4, I868, Ida Estelle Stitt.

3. John Charles Capp, born Harrisburg, June 26, I800, married July 20, I829, Sarah Singer.

4. Iohn Singer, born Lancaster, March I I, i763, died Philadelphia, May i3, I829, married Anna Maria Musser, June 20, I 793 . 
5. Captain George Musser, born March 27, I7+1, died July, I I t . married Christianna Young.

George A.Iusser. Captain of Associates Lancaster Company I77. Captain George Ross' Ist Battalion, Lancaster County, Pennsylvania. In actual service $L$ 'nited States of America in I7-6. (See Penn. Archives, 5th Series. Vol. VII. pp. I5, i6.) Went in Jersey Company August, I776, to Jersey, was away with Company until I7\%. (Muster Rolls of Lancaster Company, I7-6: also see Historical Register of Officers of Continental Army I7/5-1783. by Francis B. Hietman, revised edition, p. 4o\&. Captain George Musser. Pennsylvania.)

6. Paul Musser, born I697, married I702. Maria Barbara Cassell. Came to America I729. from Alsace and settled in the town of Falconers Swamp, about 20 miles from Lancaster. Pa.

\section{CAIRIAL.}

Louris Dale Carman: Residence, Washington, D. C., born Newark, N. J., September 5. I860. LLB.. LLM., Columbian, now George Washington University, I880-I88I. Member Bar Supreme Court, D. C.; M. D., Howard Lniversity, I88s; Georgetown University, I889. Nember D. C. Commandery Loyal Legion of U. S.; D. C. Society S. A. R. : 32d Degree Mason, etc.

Author of "Abraham Lincoln, Freemason," etc

Married Maria Gambrill of Augusta, Ga., December 22. I 897 . One child, Louise.

Son of General Ezra Ayers Carman, I834-1909, and Ala Salmon.

Son of Hon. Melancthon Freeman Carman, I807-I884, and Ann Maria Ayers, ISI3-I898. 
Son of Major Phineas Carman, I762-1827, Middlesex, N J., Militia, Revolutionary War; and Huldah Ayers, I763-I840.

Son of Stephen Carman, died 1767 , and Isabel Moores. I730-I809, who married second Moses Bloodgood and had her property destroyed by the British, winter of I776-I 777 . Isabel was a recognized patriot of Middlesex County during the Revolution and a descendant of one of the first settlers of Woodbridge.

Son of Richard Carman, Sr., I679-1768, and Abigail Kent. first wife.

Son of Samuel Carman, died I729, and Sarah.......

Son of John Carman, I633-I684, and Hannah........

Son of John Carman who reached Mass. 1631, Deputy General Court of Massachusetts in I634 and patentee of Hemp. stead, L. I., in 1643 , and who died about $165^{\circ}$; wife, Florence Fordham.

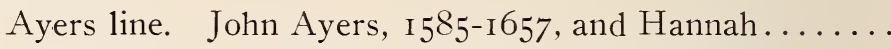

Obadiah Ayers, I636-I694, Schepen under the Dutch at Woodbridge, N. J., I673; his wife, Hannah Pike, I643-1689, was daughter of Captain and Major John Pike of Governor Carteret's Council.

Obadiah Ayers, Jr., I670-I728, wife Joanna Jones, daughter of Benjamin.

Robert Ayers, I706-I740, wife Hume ....., remarried Peter Knap.

Frazee Ayers, I729-1760, wife Phebe Bloomfield.

Ellis Ayers, I75I-I83I, private Middlesex County, N. J., Militia Revolutionary War; wife, Sarah Mundy.

Ezra Ayers, I788-I863, wife Jane Lott, I79I-I877, daughter of Levi Lott and Euphemia Cozart, father of Ann Maria.

Samuel Ayers, born 1667, son of Obadiah, Sr., above; wife Elizabeth.

His son, James Ayres, born I7I8, was a recognized patriot in Middlesex County, N. J., during Revolutionary War, having his property destroyed by the British. His wife was Hope Bloomfield and his daughter Huldah, was wife of Phineas Carman, as above. 
Also eligible by descent from Nicholas Mundy, Sr., founder of Piscataway, N. J., through Nicholas, Jr., died I734, Samuel died I78I and Samuel Mundy, second, I730-I80I, private Mirl. dlesex County, N. J. Militia, Revolutionary War; wife Elizabeth Griffith, whose daughter Sarah, I75I-I8I7, was wife of Ellis Ayers, above.

Phebe Bloomfield, above noted, was daughter of Richard Bloomfield, and Sarah, granddaughter of Timothy Bloomfield and Rose Higgins.

Son of Ezekiel Bloomfield, I653-1702, Deputy General Assembly of N. J., I697, and Hope Fitz Randolph, daughter of Edward Fitz Randolph and Elizabeth Blossom, daughter of Thomas and Anne.

Son of Thomas Bloomfield, died I676. Deputy General Assembly of N. J., I673, son of Thomas, died I639.

Rose Higgins was daughter of Jedediah Higgins, I656-I7I3; Lieutenant Piscataway, N. J.. Militia, and Mary Newbold, daughter of Michael Newbold, I623-I692, of South Jersey.

Son of Richard Higgins, Deputy General Court of Plymouth Colony. who married Mary Yates, widow of John of Plymouth Colony, October I, I65 I.

Ada Salmon was daughter of John Salmon, I797-I883, and Wilhemina Neef, who was son of John Salmon and Elizabeth Barrett; Wilhemina was daughter of Joseph Neef, I770I853, an early American educator, and Eloisa Buss.

\section{CHANDLER.}

Peleg Whitman Chandler 2d, was born in Jamaica Plain, Boston, Mass., on September 22, I884, the youngest child of Horace Parker and Grace Webster (Mitchell) Chandler. 
After finishing his work in the preparatory schools he deciderf to enter business and accepted a position in a national bank in Boston. He is now a real estate broker in Boston, specializing in Boston property. He is unmarried and lires with his parents.

Along the maternal as well as the paternal side, he is a descendant from the Mayflower Pilgrims.

Edmond Chaundelor (as the name was then spelled) came to this country in 1630 with his wife and seren children. He settled in Duxbury, Mass. He held many offices of importance and trust in the Plymouth Colony, being the first to represent the town of Duxburg as Deputy at the general Court, later having as colleagues Jonathan Brewster and John Alden. He was one of the original proprietors of the town of Bridgewater, Mass. His youngest son, Joseph, married Nancy, and their youngest son, Joseph, Jr. (Joseph Edmond), married .. Iartha Hunt.

In 1728 they moved from Duxbury to North Yarmouth (now Maine), of which Joseph. Jr., was one of the original proprietors. Their oldest son, Philip (Jos. 3, Jr., Jos. 2. Edmond) married Rebecca Phillips and remained on the home farm when his father and family moved to Maine. The third son of Philip and Rebecca Chandler. Peleg (Philip Jos. 3. Jr., Jos. Edmond) went to live with his grandparents in North Yarmouth at an early age. He became interested in the young town of New Gloucester and then in I 762 he erected a house. He married his second cousin, Sarah Winslow. He was a man of more than average intelligence, of honor and integrity, of sagacity and fine business ability, as is eridenced by the high position he took in town and church affairs. He had rast real estate holdings. He often represented his district in the General Court in Boston.

Sarah Winslow, by her paternal grandmother, was a descendant (great, great, great granddaughter) of Mr. Richard Warren, the twelfth signer of the Compact or Constitution of Government drawn up by the Pilgrims on board the Nayflower, November i I, I6:o. He, Mr. Richard Warren. was 
a descendant of Richard I. Duke of Normandy and Genevieve Aaughter of Canute, the Dane. and Emma of Normandy. The widow of Richard Warren, Mistress Elizabeth Warren. was the first woman to be rated upon the tax list of Plymouth. and one of the first purchasers of Dartmouth, near New Bedford. Mass. Sarah Winslow's paternal grandfather was Gilbart, the grantson of Kemeln and Ellen Morton (of Pilgrim fame Winslow, and the grand nephew of Gor. Edward Winslow. He held large estates is Marshfield, Mass.

The secont on of Peleg and Sarah (Winslow) Chandler, was Peleg. Ir. (Peleg s. Philip t. Jos. 3. Jr. Jos. Edmond), born in lew Glowester. Waine, $1 / 73$. He was graduated from Rhode Island Cullege (now Brown University) in 1795 . His classmate and roommate was Ezeriel Whitman, afterward ILaine's illustrious Chief Justice. Peleg Chandler took up the profession of law, soon beconing one of Maine's foremost adrocates.

He married in I797 Esther, the third daughter of Col. Isaac and Salome (Merrill) Parsons, ci New Gloucester. In 18I - he was made a Judge for the Maine Circuit. which office he filled with distinction until his removal to Bangor, in 1825 . It is probable that few men in New England enjoved so illustricus a coterie of friends as did Judge Chandler. By ties of blood or marriage he was connected with the Warrens, Win. slows, Aldens. Chief Justice Theophilus Parsons, Wm. Ellery, and that eminent Theologian, Wm. Ellery Channing: Phillips, Haskells and Fessendens.

Pelag Whitman Chandler (Peleg 6, Jr. Peleg 5. Philip 4, Jos. 3. Jr. Jos. 2. Edmond) the acungest son of Peleg Jr.. and Esther (Parsons) Chandler, born in Vew Gloucester, Maine. in I816, was graduated from: Bowdoin College in 1834 and immediately commenced the study of law in his father's office in Bangor. He was admitted to the Massachusetts Bar in I837, and that same year married Martha Ann Bush Cleaveland. a daughter of Prof. Parker Cleaveland, of Bowdoin College fama. He soon became one of Boston's most eminent advocates; was City Solicitor; served in both branchss of the Assembly, and in $185+$ was a member of the Executive Council 
an honored Trustee of his distinguished Alma Mater from i 871 to 1889 , and which in 1867 conferred on him the degree of L. L. D. He it was who established the Law Reporter, compiled The American Criminal Trials, and was first to introduce the report of Court proceedings in the daily morning papers. In the development of that section of the city of Boston known as the Back Bay, he was one of the originators and promoters. But for the indomitable perseverance of Peleg Whitman Chandler the city of Boston might never have had the beautiful Public Cardens. While serving as City Solicitor the question arose as to the taking of that land for such a purpose, and it seemed doomed when Mir. Chandler called and addressed Public Meetings, and at his own expense caused flyer to be sent out. The result every resident and visitor looks upon with pride and satisfaction. He died in 1889 at his home on Beacon Street, Boston, survived by three children, Ellen M.. Horace P. (Peleg 7, W. Peleg 6, Jr. Peleg 5, Philip 4. Jos. 3. Jr. Jos. 2, Edmond), the father of the subject of this lineage, and Parker C., a prominent New York City lawyer.

BIOGRAPHICAL SKETCH OF EBENEZAR PARSONS.

Ebenezar Parsons, the youngest child of Geoftrey and Sarah (Vincent) Parsons, was born in Gloucester, Massachusetts, January 28, I68I.

His paternal grandfather was James Parsons, Esq.. of Kemerton Manor, fourteen miles north of Gloucester, in Cloucestershire. England. Geoffrey, the father of Ebenezar, came to Gloucester in the Cape Ann, via Barbadoes, in I654. He was only twenty-seven years of age. and yet had accumulated a considerable amount of money and was able at once to pur- 
chase a house and much land. He identified himself with crery intsrest of his adopted town, and soon became known as Gloucestar's wealthiest and most prominent citizen. For many years he ssrved on the Board of Selectmen and Assessors. He married on March II. I6 57 . Sarah. daughter of Willian and Sarah Vinson later spslled Tincent), of Gloucester. William Tinson was the son of Sir Francis Tinson, of Stoke D'Aubunon, in County Surry: Sarah, his wife, was the daughter of Sir Francis Poulet. She was maid of honor to Queen Anns. wife of James I. Besides the daughter, Sarah, the wife of Creoffrey Parsons. William and Sarah Tincent had a daugh. tor. Hannah. who became the wife of William Ellery: and they were the grandparents of William Ellery. one of the signers of the Eeclaration of Independence: and great. great, grandparents of the distinguished theologian. William Ellery Channing. D.D.

On February 3, I704. Ebenezar Parsons married Lydia, the daughter of William and Mary Brown Haskell, of Gloucester. $B y$ this marriage were connected two of the wealthiest and most influential families of Cape Ann. Mr. Haskell owned an extensive grist and saw mill, as well as other valuable property, where now stands the town of Rockport.

Ehenezar Parsons was, fer a long time, one of the Selectmen and Assessors of Gloucester, and a Deacon and Ruling Flder in the First Church. His business was that of a trader. as well as farmer, and today his descendants may be found carrying on business on the spot where, two centuries ago, he amassed a fortune. One of his grandsons, Theophilus Parscns. Esq.. became Chief Justice of the Supreme Court of Iassachusetts and one of the most learned and eminent jurists the State has erer known.

The fifth child of Ebenezer and Lydia Haskell Parsons was Isaac. who on July 4. I739. married Hannah. the daughter of Captain Thomas Burnham. of Ipswich. Their oldest child. Isaac. Ir.. born April I4, I740, upon attaining his majority decided to try his luck in the far eastern country. as that part of the Province of Massachusetts Bay, now Maine, was 
then known. His grandfather, Ebenezar Parsons, was one of the sixty inhabitants of old Gloucester on Cape Ann, to whom a large tract of land in that eastern country had been granted. On February 27, I738, the lots were drawn and it was roted thai the township be called "New Gloucester." In Juna, I 761 , Isaac Parsons, Jr., took passage in a sailing vessel for North Yarmouth (now Maine), and traveled on foot over the "new way" from Cousn's River to New Gloucester, determined to learn for himself the possibilities of the young town.

He soon formed the opinion that it might be made a good country by industry: therefore the lot drawn by his grandfather, Ebenezar, was purchased and deeded to him. At once he commenced the erection of a frame house, the first in New Gloucester, and which is standing today, in a good state of preservation.

When the Revolutionary War broke out, Isaae Parsons was quick to take his place among the men to enlist, and served as Captain and Colonel of the 4th Cumberland Company Regiment, Massachusetts Militia, until its close. Colonel Parsons was a man of great and good influence in his adopted town, of strong intellect, independent in character, an original thinker and progressive in his ideas, a gentleman of the old school. very correct and precise, and extremely proud of his military honors.

He often represented his district at the General Court in Boston. He was one of the Overseers incorporated and provided by an "Act to establish a College in the town of Brunswick, in the District of Maine, within the Commonwealth of Massachusetts, to be known by the name of Bowdoin College. He served upon the above-named Board nineteen years, and it is chronicled that he "was most punctilious in his attendance upon Board meetings," making his trips in his Boston chaise drawn by a beautiful black stallion." It is ? well-authenticated fact that among the list of alumni of Bowdoin are a greater number of his descendants or men connected to him by ties of marriage than any other two men. So that he may well be called the grandfather of Bowdoin 
College! Colonel Parsons had learned the tanning business from his father, and, quick to appreciate the need of such in the "new country," he erected a mill on the small stream flowing across his land. He was the first to raise corn in the now State of Maine. This he did upon "burnt land" having by strict examination, found that such land became light and mcre suitable for the roots of any vegetable to penetrate in quest of nourishment, and also had the benefit of alkaline salts. He ever claimed that "the knowledge of his method of raising corn proved a greater encouragement or inducement to the settling of the State of Maine than any other one thing except the withdrawing of the Indians!"

There is in possession of one of his descendants the deed of land of that section ( $\mathrm{New}$ Gloucester) given by the Indian Sagamores and signed by the chiefs, Robin Hood, Duriquin and Worumbo. It is, of course. timeworn and yellow, but the writing is still legible, and the marks of the Indians can be distinctly made out.

Colonel Parsons also had a Justice's commission and for many years was Deacon of the First Orthodox Church; and it is related that the selection of a title by which to address the honored, learned and devout gentleman, often caused much embarrassment. On November 21, I765. Esquire Parsons married Salome, the daughter of Humphrey Merrill, of Falmouth. To them were born eight children. Esther, the third daughter, became the wife of Judge Peleg Chandler, Jr., of New Gloucester. They were the great grandparents of Peleg IVhitman Chandler, 2nd, whose name forms the headline of this article.

\section{CHASE.}

Ernest Luverne Chase, born Ciifton Hill, Missouri, November I3, I888, son of Cephas J. Chase and Lillian Trussell; son 
of George Washington Chase and Mary Ann Bradshaw, son of Thomas Jefferson Chase and Rebecca Romine, son of John Merrill Chase and Miriam Murray, son of Jonathan Chase and Hannah Merrill, son of Rev. Nathan Chase and Joanna Cheney Pike; Rev. Nathan Chase, Revolutionary Soldier, born I75I, died I825; descendant of Aquilla Chase, of Newbury, Mass., to I670, mariner, landowner, ctc.

\section{CLARK, OF N. Y.}

Addison L. Clark, born Schoharie County, N. Y., January 9, I89I ; son of L. W. Clark and Ella M. Travell, son of John A. Clark and Catherine Van Der Voort, son of Randall Clark and Dorcas Tucker, son of Job Clark and Anna (IVilcox) Heron, son of Nathan Clark, Lieutenant Revolutionary War. son of Wm. Clark and Hannah Kuright.

Joseph Clark, Colonial Ancestor, was Deputy General As. sembly, etc.

\section{CLARK.}

Eliot Albert Clark, born in Saybrook, Conn., December 23. I866; married Mary Ellen daughter of Timothy D. and Jane E. (Frances) Hotchkiss; one child, Luella Julia Clark; memter Sons of the American Revolution, Society of Colonial Wars; resides Pittsfield, Mass. 
Son of Hiram Hough Clark, born Chester, Conn., February 29. I824; was a member of the Connecticut Legislature in I854: at his death in Chester, Conn., March I 5, I9I2, he was the oldest ex-representative living; married in Detroit, Mich. October 3I, I864, Julia Jeannette Eliot, who was a direct descendant of Rev. John Eliot, the Apostle to the Indians, also of Capt. Isaac Johnson, who was killed as he reached the felled tree-trunk which was the only means of access to the fort, in the "Swamp Fight" December 19, 1675; Lieut William Chittenden, John Alden and Priscilla Mullins of the Mayflower, Gov. George Wyllys, Gov. Wm. Leete, Gov. John Haynes, whose wife Mabel Harlakenden, was a descendant of King Alfred the Great.

Grandson of Calvin Clark, born Chester, Conn., May 24. I79I, died there March 24, I828. He served in the Connecticut Militia in the War of 1812; married November 30, I820, Phoebe Hough, a descendant of Lieut. Wm. Pratt, Capt. Geo Denison the great Indian Fighter, Capt. John Gorham, John Howland and John Tilley, of the Mayflower.

Great grandson of Capt. Zachariah Clark, born Saybrook Conn., I734, died Saybrook, Conn., April 9, I8I4; married second Ann Bushnell, July 2, I780. He was in the French and Indian Wars, being a member of the Relief Expedition to Fort William Henry; also served as Lieutenant in the seventh Regiment Connecticut Troops.

Great, great grandson of Joseph Clark, born Saybrook: Conn., January 23, I692, died Saybrook, Conn., September I0, I770, married first Lydia Grinnell, great granddaughter of John Alden and Priscilla Mullins, second, after I726-Priscilla.

Great, great, great grandson of Major John Clark, born Saybrook, Conn., November 1655, died Saybrook, February I7. I735, was a Major in the expedition against Canada in the Colonial Wars, married December I7, I684, Rebecca Beaımont.

Great, great, great, great grandson of John Clark, born 
England, died Saybrook, Conn., September 21, I677, married October I6, I650, at Saybrook, Conn., Rebecca Porter.

Great, great, great, great, great grandson of John Clark, the immigrant, came from Braintree, near Chelmsford, Essex County, England, settled at Cambridge, Mass., as early as I632; came to Hartford with the Rev. Thomas Hooker's Company; was in the first division of lots at Hartford in I639, and had twenty-two acres; was one of the Committee to apportion the land; was a Juror at Hartford in I64I ; was second in command in Capt. John Mason's band of ninety men in the Pequot War; was one of the nineteen Patentees of the Charter of Connecticut in New England in America in I662; was in England as Agent for the Colony of Rhode Island in I 663 ; one of a Committee appointed in behalf of the legatees of Joshua Uncas; Deputy to the General Court at Hartford I64I-42-44-49-5 I-52-53-54-55-56-57-58-59-6I-62-63-65; Commissioner for Saybrook May, I664. He moved from Hartford to Saybrook sometime after I640; in 1647 was desired by the General Court to build a Fort at Saybrook, of which he was afterward in command. In May, I65 I, he was desired by the General Court, in company with the Governor and Mr. Cullick to go to Stratford and try Goody Bassett for her life (Witchcraft) ; moved from Saybrook to Norwich about I660; from Norwich to Milford about I664, where he died, I673-74. He was the first Secretary of the Colony of Connecticut, again in May, I665; married Mary Coley, daughter of John.

Grandson of Alexander McGilvrae Eliot, born January 24. I802 in Durham, Conn., married January I, I835; Chester Conn., Julia Ann Tyler; shortly after he moved to Ohio, settling at Lewis Centre, Delaware County, where he was a large land-owner, died there March I9, I86I. Julia Ann Tyler was a granddaughter of Captain Simon Tyler of Haddam, Conn., who was a Mariner, and during the Revolution a privateer; while ashore on Long Island after provisions was captured by the British and confined in the "Old Sugar House Prison" from where he escaped and made his way back to his home in Connecticut. 
Great grandson of Timothy Eliot, born July I, I772, in Guilford, Conn.; married December i8, I799, Lydia, daughter cf Samuel Bartholomew; was a farmer in Durham, Conn., where he died October 30, I848. Lydia Bartholomew was a granddaughter of Ensign Titus Munson, who died April I2, I776, in the Revolutionary Army on Long Island.

Great, great grandson of Timothy Eliot, born October 23 I736, in Guilford Conn. : married May 26, I772, Rebecca Rose, daughter of Jacob Rose, and a descendant of Sergeant. Daniel Hubbard, one of the Patentees of the town of Guilford from the Governor and Council December 7, I695. Timothy Eliot served on Committee of Inspection for Guilford during the Revol tion.

Great, great, great grandson of Abial Eliot, born 1692 Guilford, Conn., married, I726, Mary, daughter of John Leete of Guilford, and great granddaughter of William Leete, Governor cf Connecticut, who was born in Dodington, Englani in I6r2 or I3, and served for some time as Clerk in the Bishops Court at Cambridge, England. He came to America with the Rev. Mr. Whitfield's Company and was one of the signers of the Plantation Covenant on ship-board June I, I639, arriving at New Haven about July i3. He settled at Guilford where he was clerk of the Plantation from I639 to I662. He was Deputy from Guilford to the General Court till I650; Magistrate from I65I to 1658 ; chosen Deputy Governor of the New Haven Colony, 1658 , and continued in that office till he was chosen Governor, in I66I, which office he held until the union with the Connecticut Colony, in I664-65. After the union he was assistant until I669, when he was elected Deputy Governor of Connecticut Colony, holding this office until i676, when he was chosen Governor, keeping this office until his death, at Hartford, April i6, I683.

Treasurer John Talcott made an entry in his account books that it cost the Colony eleven pounds of powder for firing the "Great Gun" at Govenor Leete's funeral.

John Leete, who is said to have been the first white child born in Guilford, married Mary, daughter of William Chitten- 
den, who was Lieutenant of the New Haven Artillery Company in 16.8 .

Great, great, great, great grandson of Joseph Eliot, born December 20, 1638, Roxbury, Massachusetts, married for his second wife Mary, daughter of Samuel Wyllys and Ruth Haynes. Samuel Wyllys was born in England, I632, came to America in 1638 ; graduated from Harvard 1653 ; was one of the signers of the Royal Charter granted by Charles II to Connecticut in 1662; was Assistant to the Governor from I654 to I 685; Commissioner of the United Colonies I66I ; was a son of Governor George Wyllys from Fenny Compton Warwick, England; came to America in 1638 and was of the original planters of Hartford. (The Charter Oak stood on his land); was one of the framers of the Constitution of I639; April II, 1639, was chosen one of the six Magistrates of Connecticut, held this office till his death. In I64I was elected Deputy Governor; in 1642 Governor of Connecticut Colony; died at Hartford March 9, I644.

Ruth Haynes was daughter of Governor John Haynes, born Coddicot, England, in I594, came to America in the Griffin in I633, with the Rev. Thomas Hooker; was chosen Governor of the Massachusetts Bay Colony in 1635 ; moved to Hartford in I637; was Governor of Connecticut alternate years from 1637 to 1653 .

President of First General Court I637; Commissioner of the United Colonies 1653; Colonel of a regiment raised for service against the Indians.

Mary Wyllys, through her mother, Mabel Harlakenden, was a descendant of William, the Conqueror, Alfred the Great and through the Saxon Kings from Henry II.

Joseph Eliot, A. B., Harvard, I658; for the first three years after his graduation he was "Imployed in the Indian worke" with his father, the Apostle John Eliot, and received the "compensation of about $t$ IO annually." $\mathrm{He}$ was later associated with the Rev. Eleazer Mather in the Ministry of the Northampton Church. On January I, I663, the town of Northampton voted to build him a house and offered other inducements if 
he would settle with them permanently, but be was prevailed upon to go to Guiliord, where he was ordained Pastor of the Church in $166_{4}-65$. He seems to have also acted as Physician and the Guilford records in I683 say that "poyson was to be gotten of the Rev. Mr. Eliot with his directions for the improving of it for the poysoning of the wolves." In I68I the General Court at Hartiord made a grant of land of 200 acres to II - . Eliot.

He also received valuable grants of land from the town of Guilford; the greater part of this land is owned by his descendants. He died May 24. I694. after about thirty years of service.

Great, great. great, great, great grandson of John Eliot. called the Apostle to the Indians, was baptized at Widford. Hertfordshire. England. August 5. I604, died May 29, I69o. at Roxbury, Mass. He was educated at Jesus College, Cambridge, England, 1618-1622: taught in the school of Thomas Hooker at Little Baddow, Essex, Eng., part of the time before he came to America, which was in I6́3 I in the ship Lion. He landed in Boston November + and took Mr. Wilson's place in the Boston Church during Mr. Wilson's absence in England: was settled over the church at Roxbury in 1632 . He married September 4. I632, Hanna Mountiord. He was pastor of the church in Roxbury till his death May 29. I69o. September I4, 1646 he preached his first sermon to the Indians in the Wigwam of Kitchomakin near the mouth of the Neponset River.

The first book printed in the Anglo-American Colonies was a copy of the Psalms, generally known as the Bay Psalm Book, of which he was one of the translators. After this he translated the Bible into the Massachusetts Indian language. besides publishing a large number of books and pamphlets, some of which were in the Indian langruage.

The Lenox Library has original copies of several of his publications.

In December, 1675, he was sent with Major Gookin and Major Willard as a committee appointed by the Council at Boston, to Chelmsford and oth :r places to quiet the Indians. 


\section{COLCOCK.}

Charles Jones Colcock (son of John Colcock, by his wife, Millicent, daughter of Joseph Jones by his wife, Mary, daughter of Robert, eldest son of Col. Miles Brewton), was born in Charleston, S. C., August II, I77 I, and was baptised at St. Michael's Church on the 3oth of October following by the Rev. Robert Cooper, whose sponsors were his great aunt, Mrs. Rebecca Motte, of the arrow incident of the Revolution, Jacob Motte and Robert William Powell. He was Solicitor of the Southern Circuit, twice returned to the South Carolina House of Representatives, a Circuit Judge, Associate Judge, one of the three judges of the Court of Appeals, President of the Bank of the State, a patron of the Charleston Library, one of the founders of St. Peter's Church, destroyed by fire in I86r : President of the Board of Trustees of Charleston Medical College, and was installed December 22, I8i6 (Masonic reckoning) of the Right Worshipful Grand Lodge of South Carolina Ancient York Masons, being active in effecting a union between them and the Grand Lodge of South Carolina on December 26, I8I7; he died in the 68th year of his age, January 26, 1839 , at Charleston, and was buried in St. Peter's churchyard. He married at her father's home near McPhersonville, S. C., A. D. I795, Mary Woodward, born November 23. I774, daughter of Major Thomas Hutson in the Voluniteers of the American Revolution, by his wife, Esther, daughter of William Maine, by his wife, Judith, daughter of Henry Gignilliat, by his wife Esther (aunt of Gen. Francis Marion), daughter of Judith Baluet, by her husband, Benjamin Marion, son of Perinne Boutignon, by her husband, Jean Marion, son of Gabriel Marion of Rochelle, France.

Henry Gignilliat was the son of Jean Francois Gignilliat born at Vevay in Switzerland (son of Abraham Gignilliat by his wife Marie de Ville) by his wife Suzanne Le Serrurier daughter of Jacques Le Serrurier (one of this name was a marshal of France).

Jacques Le Serrurier by his wife Elizabeth Le Ger, had four 
danghters:-I. Catherine who married the Hon. Henry Le Noble and were progenitors of many of the Marions, DeVeauxs, DuBoses, Hamptons, Mazycks, Ravenels, and Dwights; II Marianne who married Isaac Mazyck; Ill. Madame Pierre de St. Julien from whom descend the families of Jervey and others; IV. Susanne married Jean Francois de Gignilliat from whom derive a branch of the Hutsons, and the family of Colcock.

The children of the Rev. William Hutson, by his wife, Mrs. Chardon, relict of Isaac Chardon, nee Nary Woodward, were Nary Hutson married Arthur Peronneau; Elizabeth married Isaac Hayne the Martyr; Richard Hutson, the Chancellor, and exile to St. Augustine, and the first Intendant of Charleston; Major Thomas Hutson married Esther Maine as mentioner above; Esther Hutson married William Hazzard Wigg and Anne Hutson married Gen. John Barnwell.

Mary Woodward, wife of the Rev. William Hutson, was a daughter of Col. Richard Woodward (son of Dr. Henry Woodward, who was the first permanent English settler in South Carolina, who accompanied the Sanford expedition to Port Royal in 1666, and remained among the Indians at that place to learn their customs and language, later a Member of the Colonial Council, who married Mary, daughter of Col. John Codfrey, Member of Council and at times Acting Governor of the Colony), by his wife, Sarah, born November 20, I6go. daughter of James Stanyarne, born I661, died I703, Member of the South Carolina House of Commons, by his wife, Rache! (said to have been a daughter of Jonathan Fitch, member of the Colonial House of Commons).

Charles Jones Colcock, by his wife, Mary Woodward Hutson, had the following sons: I. Thomas Hutson Colcock, a member of the Nullification Convention; II. John Colcock, born March 6, I799, a cotton factor of Charleston, S. C.; III. William Ferguson Colcock, born November 5, I804, a member of Congress, and for many years Collector of the Port of Charleston, S. C. ; IV. Richard Woodward Colcock, a graduate of West Point in the same class with Albert Sidney Johnston, 
and was the Second Superintendent of the South Carolina Military Academy, resigning from the army to accept this position.

All of these sons married and left children.

Thomas Hutson Colcock, eldest son of Judge Colcock, was born August Io. I797, and died May 6, I85 I. He was admitted to the bar in I818, and marricd July I5, I8I9, Eliza Mary, daughter of Samuel, granddaughter of Col. A. Hawkes Hay of the American Revolution. He had children: I. Charles Jones Colcock, born I820; II. William Hutson Colcock, born November 2, I82I, and married Ellen, daughter of Col. William Lynn Lewis, descended from Col. John Lewis, the pioneer settler of Augusta County, Va.; III. Richard Hutson Colcock, born August 18, I823, married his cousin, Eliza Mary, daughter of his uncle, John Colcock. He was a partner of John Colcock in their factorage business in Charleston, was Captain of the Charleston Light Dragoons in the war between the States, C. S. A., died September I5, I891, in McPhersonville, S. C., Beaufort County. IV. Samuel Hay Colcock d. s. p.; V. Esther Hutson Colcock, born I83I, died July 25 , I893, married William Douglass Gregorie. VI. Thomas Hutson Colcock, born in March, I835, died June 29, I900, married Mary Fuller, daughter of Governor A. G. Magrath. He was a cotton factor and broker in Charleston, S. C.

Charles Jones Colcock, eldest son of the above Thomas H Colcock was born April 30, I820, died October 22, I891, was married three times: Ist, to Caroline Heyward, granddaughter of Thomas Heyward, jr., the signer of the Declaration of Independence; married 2d, Lucy Frances Horton of Huntsville, Ala.; married 3d, Agnes Bostick. He was a Director of the Bank of the States, a Director of the Memphis, Chattanooga and Charleston R. R., the Originator of the Charleston and Savannah R. R., for which he was a Director; organized the $3 \mathrm{~d}$ S. C. Cavalry and, acting general, commanded the third military District in the C. S. A. during the Civil War, and was in command of the battle of Honey Hill, at which a brilliant victory was won by $\mathrm{I}, 400$ Confederate troops against 6,000 
Federal troops in November, I864, near Grahamville, S. C. Col. Colcock left five children at his death, the eldest of whom is the writer of this sketch. Prior to the Civil war, Col. Colcock was a large cotton factor in Charleston, S. C., in the firms of Fackler \& Colcock and later of Colcock, McCauley and Mollo: ; his children now living are: I. Charles Jones; II. Franis Horton; Catherine; Helen; and Villiam.

Charles Jones Colcock, eldest son of Colonel Charles J. Colcock, by his second wife, Lucy Frances Horton of Huntsville, Ala., was born January I7, I852, on his father's plantation. "Bcnnie Doon," Beaufort District, South Carolina. He attended the College of Charleston, taking the full Classical and Modern Language Course, and later entered Union Col.. lege. Schenectady, N. Y., where he was graduated in I875, with the degree of C. E., and was offered the position of Tutor at that college, where he taught for two years. Returning to South Carolina about i878, he managed his father's large cotton plantation for several years, and married in 1883, at Barnwell, S. C., Patti Lee Hay, daughter of Judge Samuel Hay, by his wife Susan C. Hay, and they have one surviving child, a daughter, Erroll Hay Colcock.

Not long after his marriage, Charles J. Colcock accepted a position at the Porter Military Academy, Charleston, S. C., and become headmaster of that institution, which position he now holds, and has charge also of the departments of Mathematics, Physics, and Chemistry. He is one of the board of managers of the South Carolina Historical Society, resigned from the board of managers of the South Carolina Sons of the Revolution, is Deputy Commander for South Carolina of the Order of Washington, a member of the order of the Imperial Yellow Rose of Europa, Canada, and the United States of America, is a member of the Huguenot Society of Charleston, S. C., and for many years has served on the vestry of the Church of the Holy Communion, Charleston, S. C., is President of the South Carolina Branch of the Alumni Association of Union College, and President of the Social Club of the Porter Military Academy. His First American Ancestor was Cap- 
tain John Colcock, who retired from the sea and settled in Charlestown, about I730, married Deborah Milner and was a merchant of Charles Town, and was Iikewise a Justice of the Perce.

Captain John Colcock had a son, John Colcock, who was also a Justice of the Peace of Charles Town, born at Charles Town, I744, practiced law, and married at St. Michaels Church, Charlestown, S. C., Millicent, daughter of Joseph Jones, by his wife Mary, daughter of Robert, eldest son of Col. Miles Brewton; her sister, Frances Brewton, married their first cousin, Charles Pinckney, and was mother of the celebrated Charles Pinckney; another sister was Rebecca Brewton, married Jacob Motte and was the matron of the arrow incident of the Revolution.

John Colcock, Jr., was admitted to the practice of law in the Court of Common Pleas in 1767; was Secretary and Correspondent of the Charlestown Library Society; was Justice of the Peace for Berkeley County; was Deputy Clerk C. \& P. for the Southern Circuit; was Assistant to the Commissary General of South Carolina; was a member of the First Provincial Congress of South Carolina 1775; and was Secretary of the Privy Council of South Carolina at the opening of the Revolutionary War.

His son was Judge Charles Jones Colcock, who is introduced at the beginning of this sketch.

COX.

Edwin Birchard Cox was born in Boston, Mass., January 3I, 1859, and is the son of Charles Motley Cox and Emeline 
Brewer Vose, daughter of Ebenezer Vose and Nancy ITheaton Draper.

Great grandson of Nathan Vose and Mary White.

Great, great, grandson of Edward Tose and Abigail Rogers

Great, great. great grandson of William Tose and Marr Babcock.

Great, great, great, great grandson of Edward Vose and Atigai! Thomas.

Nathan Tose, the Revolutionary ancestor, was born in Mill. ton. March Io, I 746 , and died in Milton July 7 , I822. He was a private in Capt. Oliver Tose's Company, Col. Robertson's Regiment, I775-July I, I780; discharged November II, I780.

The ancestor, Robert Vose of Milton. Mass., bought the estate of John Glover in Milton July I3, I654; one of the three petitioners for the incorporation of the town of Milton; Selectman I669-I679.

Edward Vose, his son, was Selectman 1695; Sergeant in Militia 1680. Regiment that traveled to Roxbury. Payroll for 6 months' men raised by town of Milton for service Continental Army during 1780 .

\section{CULTER.}

Francis Barnum Culver, A. B., born in Baltimore, Md., November I2, I868; received the degree of Artium Baccalaureus at Johns Hopkins University in June, I889; married Mary Catharine, * daughter of the late Dr. Hiram Louis Spicer, by his wife, Mary C. Scharf (deceased), who was a sister of the late Colonel John Thomas Scharf of Maryland, the historian, soldier and literateur; is a member of the Order of Washington, Sons of the American Revolution and Maryland Historical Societies; resides in Baltimore.

* Now divorced. Issue: Francis Edward Culver. 
Great, great, great, great grandson of Edward Culver, senior (I610-I685), the Puritan and Colonist ; born in England, I6I0; member of Massachusetts Bay Colony at Boston in I635; founder of Dedham, Mass., in 1636; married at Dedham, September 19, I638, Anne Ellis; removed to Roxbury, Mass, in I646; removed to New London, Conn., in I652, where he had a house-lot in the town and a farm of 400 acres at the head of the Mystic river in New London County; was a noted partisan and leader in King Philip's War, I675-76; died in New London County, Conn., in 1685.

Great, great, great grandson of Lieutenant Edward Culver. (I653-I732), landed Proprietor; son of Edward and Anne (Ellis) Culver; born at New London, Conn., in I653; soldier in King Philip's War, I675-76; removed to Norwich, Conn., in I680; was a founder, original proprietor and landowner of Lebanon, Conn., in I698; member of committee to establish the bounds of the "Volunteers' Lands" in Windham County. Conn., in 1705 ; Lieutenant in command of Connecticut Scouts in I712; original Proprietor and land-owner of Litchfield, Conn., in I72I; died at Litchfield, April 7, I732. He married at Norwich, Conn., January I5, I682, Sarah Backus (born I663), daughter of Lieutenant William Backus, Jr. ( I639I72I), Proprietor of Norwich, by his wife, Elizabeth Pratt (I642-I730), daughter of Lieutenant William Pratt (died I678), Proprietor of Hartford and Commissioner for Saybrook, Conn., by his wife, Elizabeth Clark, who was a daughter of Hon. John Clark (I598-1674), of Saybrook and Milford, Conn., one of the Grantees named by King Charles II in the Connecticut Charter of I 662, and one of the most distinguished and influential members of the colony.

Great, great grandson of Sergeant Samuel Culver (I69I-I770), landed Proprietor; son of Lieut. Edward and Sarah (Backus) Culver, born at Norwich, Conn., February II, I69I ; original Proprietor of Litchfield, Conn., in I72I; held several local offices there and was an extensive landowner; was a Representative for Litchfield in the General Assembly of Connecticut in I74I; had the military title of Ser- 
geant; died at Litchfield in I7\%o. He maried at Lebanon, Conn., May I3. I7I4, Hannah Hibbard ( I69I-I 770), daughter of Robert Hibbard. Ir. ( I6+8-IтIo), of Windham, Conn., by his wife. Mary Walden (died I/36), daughter of Edward Walden (died I679), of Wenham, Mass.

Great grandson of Jonathan Culver (I726-I808), farmer and landowner: son of Samuel and Hannah (Hibbard) Culver, born at Litchfield, Conn.. . Iarch 5. I726; removed to Spencertown, Albany County, ‥ Y., about I770; was appointed Supervisor of Public Roads for King's District (Canaan. Columbia County), \. I.. in 1776 : died at Canaan in 1808. He married at Litchfield, Conn., Nov. I6, I749, Sarah Hinman (born I73I), daughter of Captain Samuel Hinman ( I 0 5I $\left.\varepsilon_{4}\right)$, military leader, proprietor and founder of Goshen, Conn., who was a son of Edward Hinman. Jr. (born 16\%2), landowner of Stratford, Conn., by his wife, Hannah Jennings ( I6 $78-I 77 \%$ ), and a grandson of Sergeant Edward Hinman (died I68I), of Stratford, by his wife. Hannah Stiles (died I6 7 ). daughter of Francis Stiles ( I600-I653), of Milbrook. Bedford County, England, and later ( I635) a first settler of TVindsor, Conn.

Grandson of Solomon Culver (I-60-I835). farmer and landowner: son of Jonathan and Sarah (Hinman) Culver. born at "Chestnut Hill," Litchfield, Conn., August I8, i 760 ; removed to Albany County, X. Y., about ITTo: resided in Spancer Township. King's District. subsequently the town of Canaan, in Columbia County, $\mathrm{X}$. Y. s served in the Revolutionary Tiar, being enrolled in the spring of I 77 . in the company of Captain Ebenezer Benjamin, of Colo. Tilliam Bradford Whiting's regiment of King's District (Albany County), militia ( $/ 7$ th N. Y. Regiment), attached to the division commanded by General Schuyler: performed honorable service at Fort George and Fort Edward. X. Y.. and was in the American retreat from Burgoyne towards Saratoga: removed to Luzerne County. Penna., about I79I, and to Ohio in I809: was a township trustee in Richland County, Ohio. I8I3. and subsequently; died near Mansfield. Ohio. April 2, I 835 . He mar- 
ried, about I782, Lodamia Burr (I764-1834), daughter of Samuel Burr (a) (I728-1815), of Farmington, Conn., who was a son of Stephen Burr (born I699), grandson of John Burr (I670-I74I), by his wife, Sarah (1675-1767), great grandson of Samuel Burr (died I682), by his wife, Mary Baysey [daughter of John Baysey (died 167I), a founder of Hartford, Conn.], and great, great grandson of Benjamin Burr (died I68I), original settler and landowner of Hartford (1636), and soldier in the Pequot War (I637) under Captain John Mason.

(a) The aforesaid Samuel Burr (I728-1815), married December 28, I752, Christiana Cadwell (I735-I782). daughter of James Cadwell (b) (I697-I77I), of Farmington. Conn., by his wife, Sarah Merry (born I706), daughter of Cornelius Merry, Jr. (i666-iz60), of West Hartford, and Bethia, his wife, and granddaughter of Cornelius Merry, Senior, of Northampton, Mass., soldier in King Philip's War, I675-'76, by his wife, Rachel Ballard.

(b) The aforesaid James Cadwell (I697-I77I), was a son of Lieutenant Thomas Cadwell, Jr. (c) (I662-I740) of Hartford, Conn., by his wife, Hannah Butler, daughter of Thomas Butler (d) ( I636-I688), who married Sarah Stone, daughter of Rev. Samuel Stone (I602-I663). Chaplain to the troops under Captain John Mason in the Pequot War ( I637) and second pastor of the First Church of Hartford, Conn.

(c) The aforesaid Lient. Thomas Cadwell, Jr. (I662I740). was a son of Thomas Cadwell, early settler of Hartford, who married the widow, Elizabeth (Stebbins) Wilson, daughter of Deacon Edward Stebbins (died I664-'68), a prcprietor of Hartford ( 1636 ), member of the Committee at Boston ( I635) appointed to try John Endicott for "defacing the colors." and afterwards eminent in the affairs of the Ccnnecticut Colony until his death. 
(d) The aforesaid Thomas Butler (I636-I688), was a son of Deacon Richard Butler (died I684), one of the first settlers and landed Proprietors of Hartford, Conn. ( I6 66 ), and Representative in the General Court i656-'6o.

Son (by second marriage) of William Edward Culver, private banker and capitalist of Louisville, $\mathrm{K}_{y}$, , in "ante bellum" days; son of Solomon and Lodamia (Burr) Culver; born in Luzerne County, Penna., July 3, 1803; removed to Ohio in I809: removed to Kentucky at an early age, retiring from business in 1857 ; died in Washington, D. C., March 12,1876 .

He married (I) in Kentucky, June I5, I826, Martha Hawkins Craig (I805-I866), daughter of Samuel H. Craig, of Woodford County, Ky.; had issue*; married (2) at Baltimore, Md., January 9, I868, Jane McClintock (born Dec. 23, I833, in Philadelphia, Pa.), daughter of Matthew McClintock (e) (I806-I885), by his wife, Susan Appleby (I8I5-I877), who was a daughter of John Appleby (I789-I834), soldier of War of I8I2, who married Elizabeth Sheild (I790-I865), daughter of William Sheild (I760-1816), a soldier of the Revolution, by his wife, Rachel Ball (I766-1857), who was a daughter of James Ball (I73I-I808), by his wife, Elizabeth Kemp (f) (I732-I8I4), of Talbot County, MId., a granddaughter of John Ball (died I76r), hy wife, Mary —_, and a great granddaughter of Lieutenant Thomas Ball (died I722), officer of the Colonial Militia of Talbot County, MId., in I696.

(e) The aforesaid Matthew McClintock (I805-I885). was a son of Samuel McClintock (I772-I856), by his wife. Jane Rankin (died 1852 ), and a grandson of Alexander McClintock, of County Donegal, Ireland, by his wife, Anne Patterson. The McClintocks were from Scotland and

*Lemuel $H_{\text {., born }}$ 828, died inf.

James E. A., born I83I, died inf.

Pauline Anne, born 18.33, married Dr. Robert Vaughan of Kentucky.

Mary E.. born 1835, married Najor A. L. Symmes, of Kentucky. 
settled in the counties of Donegal and Londonderry, in the north of Ireland, at the time of the Revolution of I688, being enrolled among the "landed gentry."

(f) The aforesaid Elizabeth Kemp (I732-I8I4), was a daughter of John Kemp (I68I-I75I), by his wife, Mary Ball, and a granddaughter of Robert Kemp (I650-I702). who married Elizabeth Webb, daughter of Edmund Webb (died I685), of Bayside, Talbot County, Maryland.

Francis Barnum Culver. B. A., born in Baltimore, Md., November I 2, I868; received the degree of Baccalaureus Artium at Johns Hopkins University in I889; married Catharine, daughter of Dr. Hiram L. and Mary C. (Scharf) Spicer, by which union there is one child, Francis Edward Culver; member Sons of the American Revolution and Maryland Historical Societies: resides at I25 Wrest 22nd Street. Baltimore, \Id.

Son of William Edward Culver, private banker and capitalist of Louisville, Ky., in "ante bellum" days; born in Luzerne County, Penna., July 3, 1803: married, January 9, I868, Jane, daughter of Matthew and Susan (Appleby) McClintock; died in Washington, D. C.. March I2, I876.

Grandson of Solomon Culver. farmer and landowner, born in Litchfield, Conn., August I8, I760; removed to Albany County, N. Y., about I 770 ; served in the American Revolution as a private in the Company of Captain Ebenezer Benjamin, Colonel William Bradford Whiting's regiment of King's District (Albany County) militia, attached to Genera] Schuyler's division; married in 1782 , Lodamia, daughter of Samuel and Christiana (Cadwell) Burr: removed to Pennsylvania about I791, to Ohio in I809; died near Mansfield, Ohio, Apri1 2, I 835 .

Great grandson of Jonathan Culver, farmer and landowner; born in Litchfield. Conn., March 5, I726; married in Litchfield, November 16, I749, Sarah. daughter of Captain Samuel Hinman, of Goshen, Conn.; removed to 
Spencertown. Albany County. N. Y., about I7/0: was Supervisor of Public Roads for King"s District (Canaan). New Fork. in 1776 ; died at Canaan. I8os.

Great. great grandson of Sergeant Samuel Culver. landed Proprietor: born at Norwich. Conn.. February II. I69I: married in Lebanon. Conn. May I3. IzIt. Hannah. daughter of Robert. Ir.. and Mary (Walden) Hibbard: was one of the founders and first settlers of Litchield. Conn., in I72I : held sereral local offices, and in I74I was a Representative for Litchfield in the General Assembly of Connecticut: extensive landowner at Litchfield. Conn.. where he died in I7\%o.

Great. great. great grandson of Lieutenant Edward Culver. Surveyor and Landed Proprietor: born at New London. Conn.. in 1653: soldier in King Philip's Mar. Ió 5 16-6: removed to Norwich. Conn., in I680. and there married. Tanuary I5. I682. Sarah, daughter of Lieutenant William. Ir., and Elizabeth (Pratt) Backus: was an original Proprietor and landowner of Lebanon. Conn.. in I698: lieutenaut of Connecticut Scouts in I 7 I2: Original Proprietor and landowner of Litchfield. Conn.. in I 721 . where he died April 7 . I 732 .

Great, great, great, great grandson of Edward Culver. Senior, the Puritan and Colonist: born in England in I6ro: member of Massachusetts Bay Colony at Boston in 1635; founder of Dedham. Mass. in 1636; married at Dedham. September 19. I638. Anne Ellis: removed to Roxbury, Mass., about I646: remored to New London. Conn.. in $16 \vdots 2$. where he had a house-lot in the town and a farm of 400 acres at the head of the Mrstic River in New London County; was noted partisan and leader in King Philip's Mar, I6/5-16,6: died in New London Countr; Conn.. in 1685. 


\section{CUTHBERT.}

Lucius Montrose Cuthbert, born at Philadelphia, Pa., August I7th, I856; graduated at Columbian (now George Washington) University, I876, Degrees A. B. and A. M.; Columbian Law School, i878, Degree L. L. B.; married, October 24th, I900, Gertrude, second daughter of Hon. Nathaniel P. Hill, United Stated Senator from Colorado; practiced law in Denver, Colorado, I88I-I908. Now President United Oil Company and Inland Oil and Refining Company, Denver, Colorado; member American Bar Association; lecturer on Roman Law at Univeristy of Colorado; member of Union and University Clubs (New York), Metropolitan Club (Washington, D. C. ), Denver University, Denver Country and Denver Athletic Clubs (Denver) and Cheyenne Mountain Country Club (Colorado Springs).

Eldest living son of Rev. James Hazzard Cuthbert. D. D., of South Carolina, and Julia Elizabeth Turpin Cuthbert, his wife, of Augusta, Ga.

The said Rev. Jas. Hazzard Cuthbert, D. D., was the eldest son of Lucius Cuthbert, and his wife, Charlotte Fuller. Lucius Cuthbert was the eldest son of James Hazzard Cuthbert, and his second wife, Fanny Furze.

The last-mentioned James Hazzard Cuthbert was the second son of Dr. James Cuthbert (born, I7i6; died, I794), who landed at Charleston, S. C., October 20th, I737, and resided at Edisto Island and Beaufort, S. C., and his wife, Mary Hazzard (born I7I8; died I794), daughter of Col. William Hazzard and widow of Edward Wigg of Beaufort, S. C.

The said Dr. James Cuthbert was the fourth son of John Cuthbert, Baron of Castlehill, Scotland, and his wife, the Honorable Jean Hay, Heiress of Dalkethy, the only daughter of the Rt. Revd. H. Hay, Episcopal Bishop of Moray, Scotland, a direct descendant of the Earls of Erroll, Hereditary Lord High Constables of Scotland, and of the Earls of Atholl.

The said Baron John Cuthbert was of a long line of Barons of Castlehill, whose direct ancestor. George Cuthbert, Baron 
of Castlehill, commanded the Royal Forces of the town of Inverness, Scotland, at the Battle of Harlaw (I4II) against the rebellious Donald, Lord of the Isles, whose standard he seized. As a recognition of these services, James II, King of Scotland, granted to him, and his descendants, forever, "a fess gules in a field d'or" as an addition to the former armorial bearings of the family ("quevre azure"); and for a crest. a hand in a gauntlet; and for motto "nec minus fortiter"; with two wild horses for supporters; "whereof the vouchers are in the Archives of the College of Heralds of Scotland."

His paternal grandmother, the said Charlotte Fuller, was a daughter of Thomas Fuller, and his wife, Elizabeth Middleton, who was a daughter of Thomas Middleton, member of the Commons House of Assembly of South Carolina ( I750-I 766), who was a son of Arthur Middleton, of "The Oaks" (I68II737), and Speaker of the Commons House of Assembly of South Carolina, and grandfather of Arthur Niddleton, one of the Signers of the Declaration of Independence.

His mother, the said Julia Elizabeth Turpin Cuthbert, was the daughter of Dr. William Henry Turpin, of Augusta, Ga., and his wife, Marie Antoinette d'Antignac, who was the daughter of Charles Jean Louis Baptiste d'Antignac, and Hannah du Bose, his wife. The said Charles Jean Louis Baptiste d'Antignac was the son of Chevalier Jean Louis Baptiste Chamberon d'Antignac, who petitioned the Continental Congress October 16 , I776, for permission to raise a regiment of light horse for the Continental Service, and offered to serve at his own expense. He mentioned therein that he had been an officer in the First Musquetters of His Majesty, the King of France, a company composed of "the First Nobility." He is mentioned in Heitman's "Historical Register of Officers of the Continental Army", as "Baron d'Antignac, Captain Continental A rtillery." 


\section{DR. M. F. CUTHBERT.}

Dr. Middleton Fuller Cuthbert, one of the leading physicians of Washington, was born in Philadelphia, where his father was at the time pastor of a church. Upon the removal of the family to Washiigton to live Mr. M. F. Cuthbert attended what was then known as the Columbia College, now the George Washington University, where he graduated in the Academic course; then taking up the study of medicine. graduating in that profession. Dr. Cuthbert comes of a long line of distinguished ancestry and descends from such ancient families as Cuthbert, Barons of Castle Hill, Scotland, the Middletons, Barnwells, Draytons, Fullers and Du Bose's and Hazzards of South Carolina, the d'Antignacs of France and Georgia, the Turpins and Ballards of Virginia and others. He is the son of the late James Hazzard Cuthbert, D.D., of South Carolina, and Julia Elizabeth Turpin, daughter of William Henry Turpin and Marie Antoinette d'Antignac, descended of the Baron d'Antignac. James Hazzard Cuthbert, D.D., was the son of Lucius Cuthbert and Charlotte Fuller, daughter of Thomas Fuller and Elizabeth, daughter of Col. Thomas Middleton and Ann, daughter of Col. Nathaniel Barnwell. Thomas Fuller was the son of Col. Thomas Fuller and Lydia Hazzard, son of Richard Fuller and Mary Drayton. Lucius Cuthbert was the son of James Hazzard Cuthbert, son of Dr. James Cuthbert and Mary Wigg, widow, daughter of Col. W'm. Hazzard. We thus see the ancient descent of Dr. M. F. Cuthbert from the founders of America.

For line of descent see Cuthbert Barnwell Brown, whose mother, Mary d'Antignae Cuthbert, was sister of I. M. Cuthbert anci Dr. II. F. Cuthbert. 


\section{de BONMIITELL.}

\section{French Coat of Arms}

Argent, two lion lespards passant in pale proper.

\section{English Coat of Arms}

Or on a bend sable, three mullets (6) argent.

Crest. A demi lion rampant, supporting an anchor ppr.

The family of de Bonneville (the name is frequently written Boniwell, de Bonderille, Bondeuile, Bonville, Bonavil, etc.), is one of the oldest of the French Nobility. Their estates were situated at Bonnerille, Langres, Limoges and Rouen, Normandy, and date back to the earliest feudal days.

The first English de Bonneville of whom we have record was Richard de Bonderille, who took part in the battle of Hastings, I066. under William the Conqueror, and his name is inscribed in the famous Battle Abbey Roll. This de Bonneville was the progenitor of the British Families of this name.

In I 65 the son of Robert de Bonarille held lands in YorkLiber Niger. "In 35 Henry Iî. W'illiam. son of Nicholas de Bonrile, haring all the accoutrements prepared at the King's charge solemnly receired the honour of Knighthood on the Festival of our Sariour's Iativity. the same year; and, upon his father's death in 49. Henry III had liver: of his land, lying in Com. Somers"-Dugdale.

His successor was Nicholas, who died in I29t. and he was followed by still another Nicholas, the latter taking part in the Battle of Boroughbridge. I322. then W'illiam, whom we find as Sir IVilliam de Bonvill. Sheriff of Dorset and Somerset and some rears later Deronshire. He had considerable psssessions in the West Country with his seat at Chuton-. "Wifcombe a fair manor place fumtrme the Lord Bonville"s. The present Bridewell of Exeter was his town house." At Exeter he founded a hospital for twelve poor men and women.

He was followed in I 408 by his grandson and namesake, a 
soldier of renown in the French Wars, who inherited another Somersetshire estate from his cousin, John de Bonavile, of Meryat. He first took the field in the retinue of Thomas, Duke of Clarence, under the victorious banner of Henry V ; then as Seneschal of Aicquitaine, was retained to serve his successor with twenty men at arms and six hundred archers and "merited so well for his services" was "fummoned by Henry VI to Parliment among the barons by the name of Lord William de Boneville of Chuton, honoured with the Order of the Garter and enriched his fon by marrying him to the only daughter of Lord Harrington." A few years after, he was constituted Constable of Exeter for life, and Lieutenant of Acquitaine.

Lord de Boneville was a zealous partisan of the House of York, and, like many other nobles who espoused this cause. perished in the havoc of the ensuing Civil Whar and none among all the fortunes that "withered with the White Rose" underwent so cruel and instantaneous collapse. Within a space of two months three generations of the de Bonevilles had been swept away. His eldest son had married the heiress of Lord Harrington and was the father of another William, who inherited his mother's barony and took to wife a daughter of the Earl of Salisbury, Lady Catherine Nevill.

Both the son and grandson were slain before his eyes at the Battle of Wakefield, December 3I, I460, and "was himself taken prisoner at the fecond Battle of St. Alban." He had been one of the Yorkish barons in whose custody Henry VI had been placed when he was taken prisoner at Northampton. thus incurring the bitter hostility of the Queen. "When the rest of the Lords (who then also being there, were intrusted with the like custody of that King) fled away to their party, he would have withdrawn himself had not the King assured him he should receive no bodily hurt." But though he surrendered on the faith of the Royal Promise that his life should be spared, it was not kept. "Such," continues Dugdale, "was the indignation of the Queen towards him, that they rested not until they had taken off his head," which occurred February I8, I46r. He was afterward, by act of Parliment, I, Edward IV, declared innocent. 
The little great granddaughter Cecily was thus, by a "singular and almost unparrelleled course of descent" left to inherit his great possessions. In her own right Baroness Boniville and Harrington, she was afterward given in marriage by Edward IV to the eldest son of his Queen, Thomas Grey, Marquis of Dorset, and was the grandmother of Lady Jane Grey. Her second husband was Lord Henry Stafford, a younger son of the second Duke of Buckingham, who was created Earl of Wiltshire in I 509, but by him left no issue.

The family had suffered an unprecedenterl series of misfortunes, and the descendants of this famous Feudal Family seemed unable to once more place their star of ascendancy in the enviable niche it had occupied through the achievements of their progenitors. A number of the de Bonnevilles came to America in the early part of the seventeenth century, settling in Maryland and taking an active part in the Revolutionary War. War of Isiz and Civil War.

William (de) Bonniwell, great grandfather of the subjects of this sketch, born, Chatham, Eng. December IO, I78I, died Montreal, Canada, October I7, I832. As a boy of twelve years of age served as a "powder monkey" under Admiral Lord Nelson at the Battle of Cape Trafalgar; married February IO, I803. Chatham, Eng.. Eleanor Hills, born at Chatham, MTarch 20, 1785; died "Bonniwell Settlement," Wisconsin, June I I, I87 I. Issue: William T., James, George, Eleanor M., Henry V., Walter and Alfred T. Seeking new fields he decided to come to America and sailed for Montreal, Can., with his wife and family, August II, I832; died shortly after reaching there.

After his death, the rest of the family came to United States and proceeded to Wisconsin, founding "Bonniwell Settlement," now known as Mequon. The mother purchased six lundred and forty acres which she divided among the children, giving each eighty acres, retaining a like amount for herself. They built their homes and erected the first school house in Ozaukee County. The children took a prominent part in the county affairs. 
James (de) Bonniwell, born Chatham, Eng., September 6, I8II, died Hickory, N. C., December 28, I893; married at Williamsburg, L. I., November 23, I832, Phoebe Capes, daughter of William and Sally (Brooks) Capes; born South Norwalk, Conn., October 9, I8I4; died at Milwaukee, Wis., March I6, I880. Issue: George Capes, Josephine M., Frank B., Julia B., Evander Berry, Roderick W., Frederick J., Donna M. and Eugene C.

Evander Berry (de) Bonniwell, born "Bonniwell Settlement" May I2, I847 ; married at Philadelphia, Pa., February 2I, I87I, Elizabeth Ann O'Doherty, daughter of Charles and Sarah (McNulty) O'Doherty. Born December 24, I849. at Glenkin, Ardmore, Londonderry, Ireland. Issue: Eugene C., Charles A., Thomas J., James F., Marie E., Josephine R. and Rev. William Raymond Bonniwell, O. P.

Charles A. Bonniwell secured his early education at the "Bonniwell School," but the outbreak of the Civil War and consequent call to arms appealed to him so strongly he enlisted November 12, I86I, being but fourteen years old; was mustered into service January 24, I862, as a private in Co. I, 2nd Wisconsin Cavalry, to serve three years; appointed bugler in January, I863; reenlisted as a Veteran Volunteer December I7, I863, and was mustered out of service as a bugler November I5, I865, at Austin, Texas.

Took part in the following engagements: Cotton Plant, July 7, I862 ; Neutonia, Mo., October 4, I862; Oakland, Miss., December 2, I862; Prairie Grove, Ark., December 7, I862; Van Buren, Ark., December 28, I862; Lick Creek, Ark., January I2, I863; Cold Water, Miss., April I9, I863; Heron Lake, Tenn., May 23, I863; Siege of Vicksburg, June I.3, to July 4, I863; Clinton and Jackson, Miss., July, I863; Redbone, Miss., September I3, I863; Bayou Pierre, October Io, I863; James Landing, Ark., June 6; I864; Clinton to Jackson, July, I864; Halls Plantation, Miss., October 3, I864; Woodville, Miss., October 6, I864; Yazoo City, Miss., December I, I864; Egypt Station, Miss., December 26, I864. 


\section{O'DOHERTY}

Coat of Arms: Argent, a stag rampant vert, on a chief vert, three mullets argent of the first. Crest: A wolf current ermine. Motto, Arn Dutchas.

The O'Doherty family is descended frcm Milesius, King of Spain, through the branch of Heremon, eighth son of that monarch. The O'Dochartaigh (the name is now written O'Doherty), were a powerful sept, a branch of the O'Donneils. and became chiefs of Innishowen.

The founder of the family was Conal Gulban, ancestor of the Northern Hy Nials, and son of Nial of the Nine Hcstages, King of Ireland, A. D. 379. The ancient name was O'Donnell and signifies "Grandson of the Destroyer." The possessions of the sept were in the present counties of Donegal and Mayo. O'Doherty, Chief of Srd Miodliair, is, mentioned in the Annals of the Four Masters, at A. D. I I97, as being chief of all Tyrconnell.

The O'Dohertys were prominent in resisting the encoachments of the English and succeeded in maintaining their position as chiefs of Innishowen and retaining their estates until the reign of James the First, of England. During his reign their lands were included in the six Ulster counties which that Monarch confiscated from their owners to bestow on indigent conrt favorites.

After the power of the chieftains of the North had broken and the Earls of Tyrone and Tyrconnell had fled to the Continent the standard of resistance was once more raised by Cahir O'Doherty, a young chicftain of the family. He had suffered spoilation of a part of his lands and had been charged with rebellion by Sir Creorge Paulett, the Gcvernor of Dierry, who publicly insulted him and struck O'Doherty in the face

O'Doherty at once raised the standard of rebellion and took fearful and summary vengeance on his enemies. He marched by night to Culinore Fort, which he captured by stratagem. Having killed the garrison, proceeded to Derry, which he also 
captured, and slew his enemy, Paulett, and other English notables and then sacked the town.

Being joined by some of the other Northern Chieftains he withstood the armies of England for five months and was finally killed by a random shot under the Rock of Doon near Kilmaereman. His lands were confiscated and given to Sir Arthur Chichester, the Lord Deputy, and other English adventurers.

A contemporary writer describes the last of the O'Doherty chieftains as "A man to be marked among a thousand, a man of the loftiest and prondest bearing in U1ster; his Spanish hat with the heron's plume was too often the terror of his enemies and rallying point of his friends. He was chivalrous, faith ful in his engagements, firm and prompt in the execution of his designs and implacable in his resentments."

During the Penal Day priests were forbidden to celebrate Mass under penalty of death. But the unconquerable spirit of the O'Doherty asserted itself and Denis O'Doherty, great, great grandfather of the subjects of this sketch, built the first chapel in his district and known as Ardmore Chapel and which stands to-day. In this period few cases of disputes were settled by law but usually by arbitration, and he and another were appointed as arbiters for that district. The O'Dohertys were one of the first Catholic families to hold land in the North of Ireland after the Penal Days.

\section{Some Colonial and Revolutionary Ancestors.}

Thomas Rogers, great, great, great, great, great, great, great, great grandfather, born England —? died Plymouth, Mass.,.... I621. Eighteenth signer of "Signers of Mayflower Compact."

Samuel Rowland, great, great, great, great, great, great, great, great grandfather, born England — ? died Fairfield, Conn., - I69r. Admitted freeman New London, Conn., I 630.

William Kinge, great, great, great, great, great, great, 
great, great grandfather, born England, I 595, died Salem, Mass., I670. Made freeman May 25, I635, and received grant of land, 1638 .

Lieutenant Richard Brown, great, great, great, great, great, great, great, great grandfather, born England, I629, died Southold, L. I., April 27, I688. Sergeant, I670; Ensign, June I3, I685; Lieutenant Foot Company, October 8, I686.

Ensign Richard Brown, great, great, great, great, great, great, great grandfather, born Southold, L. I., I65I, died Southold, July I1, I70I.

John Ellet (Elliott), great, great, great, great, great, great, great grandfather, born England —? died Stamford, Conn., I673. Was in Watertown, Mass., I633. Sold his estate there and removed to Stamford in I650.

Captain Joseph Youngs, great, great, great, great, great, great, great grandfather, born Southold, England - ? died Southold, L. I., I658. Was admitted an inhabitant of Salem, Mass., I638, and was granted a half acre of land at Winter Harbor; also a ten-acre lot "neere Mr. Downing's Farm;" in I639 was granted thirty acres of land. Removed to Southold, L. I., about I649.

Thomas Youngs, great, great, great, great, great, great grandfather, born Salem, Mass., I637, died Oyster Bay, L. I., I720. Received grant of land at Greenwich, Conn., October 4, 1673. Removed to Oyster Bay late the next year and was made "equal freeman," I687.

Captain Samuel Youngs, great, great, great, great, grandfather, born Stamford, Conn., September 30, I7I2, died Darien, Conn., March I8, I798. In I76r appointed Lieutenant and later Captain of Train Band in Parish of Middlesex, 9th Regiment. During the Revolutionary War served in gth Connecticut Regiment.

John Brooks, great, great, great, great grandfather, born Stratford, Conn., October 8, I715, died Stratford, March 7, I777. Appointed to secure subscriptions for War Certificates and as Commissioner and Treasurer to sign Bills of State.

I,emuel Brooks, M. D., great, great, great grandfather, br, nn 
Stratford, Conn., Narch 23, I74I, died - ? Served in Captain Marvin's Company of Coast Guard —, I 782.

Hon. Thomas Fairchild, great, great, great, great, great, great, great grandfather, born —— ?ied Stratford, Conn., December I4, I670. One of the first settlers in I646. Representative in $1659-60$ and often after that.

Robert Seabrooke, great, great, zreat, great, great, great, great, great grandfather, korn London, England —? died Stratford, Conn., I650. Admitted freeman and granted land I640.

Thomas Sherwood, great, great, great, great, great, great, great grandfather, born Ipswich, England, I586, died Fairfield, Conn., I655. Resided in Massachusetts several years and came to Fairfield where he held land before ${ }^{6} 6_{5}$ o.

Captain Matthew Sherwood, great, great, great, great, great, great grandfather, born I643, died Fairfield, Conn.. - - ?

Hon. Thomas Fitch, great, great, great, great, great, great, great grandfather, born Bocking, England, about I5I2, died Norwalk, Conn., I704. Arrived in Hartford I635 and was in Norwalk in 1752; earliest date affixed to any English Norwalk deed is attached to his. Freeman in 1657 ; Selec:man, 1659; Town Clerk and Recorder of Deed, I669; Representative once before he was seventy, and four times after that.

Captain Richard Raymond, great, great, great, sreat, great, great, great, great grandfather, born —? died Saybrook. Conn., r692. Tias in Salem in I634. Came to Norwalk October 21, I662. Left for Saybrook, I664.

Sergeant John Raymond, great, great, great, great, great, great, great grandfather, born Sarbrook. Conn., September 9. i 665 , died

Captain E1. Raymond, great, great, great. oreat grandfather. born Norwalk, Conn., February 20, I720, died Norwalk -? Captain of Militia, Colonel Mead's Regiment, I777-I78I.

Hon. Thomas Betts, great, great, great. great, great, great, great, great grandfather, born London, England, about I6 5 , died Norwalk, Conn., i688. His name first appears in Norwalk Records in 1656 . At date of settlement in Norwalk he had 
been here twenty years, arriving in 1636 . Was Representative to General Assemby five times.

Matthew St. John, great, great, great, great, great, grcat, great, great grandfather, born about i6I2, died Norwalk, Conn. Octcber II, I669. One of the founders of Dorchester, Mass. Freeman. September 3. I634, removed in 1638 to Windsor and was one of first settlers in Norwalk about I654.

Hon. John Pickett, great, great, great, great, great, great, great, great, great grandfather, born about I623, died Stratford, Conn., April I I, i684. Constable r667 ; Stratford Selectman I669: Colonial Representative 1673-1675. In Salem in I648. Removed to Stratford i650.

Simon Hoyt, great, great, great, great, great, great, great, great, great grandfather, born England about I 595, died Stamford, Conn., September I, I659. Had been in Charlestown, Mass. in I629. Freeman May I8, I63I. In Scituate in I6331638 , and with his wife one of the earliest members of the church. Removed in 1639 to Windsor: then in I650 to Fairfield, and finally to Stamford.

Sergeant Walter Hoyt, great, great, great, great, great, great: great, great grandfather, born England, about I6i8, died Norwalk, Conn., about I684. Removed to Norwalk and was one of the first settlers in I653. Was Deputy for Norwalk to General Assembly of Conn., and held various offices twelve times.

Rev. Nicholas Street, great, great, great, great, great, great. great, great grandfather, born Bridgewater, Eng., January 29, I603, died New Haven, Conn., about i68o. One of the earliest settlers. Married Mary Newman, widow of Governor Francis Newman.

Lieutenant Samuel Street, great, great, great, great, great, great grandfather, born New Haven, Conn., July 27, I667, died New Haven, January i6, i7 I7.

Hon. Richard Miles, great, great, great, great, great, great, great, great grandfather, born England - ? died New Haven, Conn., January 7. 1667. Was in Milford, I639; New Haven, I643. Colonial Representative I651. 
Lieutenant Henry Glover, great, great, great, great, great, great, great, great grandfather, born Ipswich, Eng., about г6ı ; died New Haven, Conn., about I689; came to New Haven in I647 ; admitted freeman I662 and same year appointed Lieutenant of Southold.

William Capes, great, great, great grandfather, served in I 3 th Virginia Regiment which was afterward the 9th Virginia; was at French Creek and Fort Pitt.

William Capes, great grandfather, born January 24, I783, died Darien, Conn., October 3I, I854; served in the IIth Regiment New York Artillery, War of I8I 2. His son, William. was an assistant of Erickson in building the Monitor.

\section{Eugene C. (de) Bonniwell.}

Eugene C. (de) Bonniwell, son of Evander Berry and Elizabeth Ann (O'Dioherty) (de) Bonniwell; born Philadelphia, September 25, I872 ; educated at Broad Street Academy ; studied law at University of Pennsylvania, graduating in I893; democratic nominee for Legislature, 7 th Pennsylvania District, in I896; married 1900 to Madelaine H. Cahill, daughter of Bernard Cahill and Ellen Cahill, of Philadelphia. Children : Eugene Cahill, Robert Budd, John Green, Bernard, Madelaine H., Alfred, and Eleanor; democatic nominee for State Senator, 4th District, Pennsylvania, I902; president and founder Veteran Athletes of Philadelphia, the first association of its kind in the country; chairman, Keystone Party of Pennsylvania, I9Io; democratic-Keystone nominee for Congress, 7 th District, Pennsylvania, I9ı. Honorary degree of Bachelor of Philosophy, conferred by Villa Nova College; appointed Assistant City Solicitor in charge of Desertion cases, County of Philadelphia, I9II; again Democratic nominee for Congress, I9I2; I9I3, elected Judge of the Municipal Court of Philadelphia; member Sons of the American Revolution, Society War of I8I2, Sons of Veterans.

Thomas J. (de) Bonniwell.

Thomas J. (de) Bonniwell, son of Evander Berry and Elizabeth Ann (O'Doherty) (de) Bonniwell; born in 
Philadelphia, December 24. I879; educated at Broad Street Academy and Temple College.

On April 23, 1898, the late President McKinley issued his call for volunteers and the fighting instinct inherited from forbears that had lain dormant asserting itself, enlisted at Philadelphia, March 28, I898, as private in Company G, Third Pennsylvania Infantry. Went into Camp at Mt. Gretna, Chickamauga and finally Tampa, Fla. Promoted here to Corporal.

While at Tampa orders were received to embark for the scene of hostilities, but the ramming of the transport necessitated the revocation of the order. Negotiations for peace being in progress the embarkation was never made. Peace finally being declared, the regiment was ordered to Philadelphia. Mustered out of service as Corporal October 22, I898.

The late President again calling for volunteers, reenlisted at Philadelphia, July 21, I899, as private in Company K, 28th U. S. Volunteers. Promoted Corporal August 28, r899. Embarked for Philippines October 25, I899, arriving in Manila November 23, I 899 .

Served under Generals Bates and Wheaton in expedition to Southern Luzon, October 25, I899; took part in Battle of Lumumbarrio, January 7, I900; engagement Zapote Ford, January IO, I900. Promoted to Sergeant March I3, I900. Expedition to Northern Mindanao under Col. Birkheimer, December I6, I900; engagement at Silo, December 21, I900; engagement at Abonga, February 6, I90I ; in command during engagement at Timamana, February Io, I90I-detachment although outnumbered fifteen to one, defeated the enemy-engagement near Timamana, February I I, I90r.

Took part in all the skirmishes and expeditions of the Company. Served, also, in the Mounted Detachment of Battalion and Drill Master. Returned to United States and was mustered out of service as Sergeant May I, I90I, at Presidio, San Francisco, Cal.

Married at Valpariso, Chile, Senorita Jovita Leiva Hermosilla, August 2, I909. Children: Jovita Luisa, Adelaide Maria 
and Harry Raymond. Department Manager, Merchants Syndicate Catalog Co., Chicago.

Charles A. (de) Bonniwell.

Charles A. (de) Bonniwell, son of Evander Berry and Elizabeth Ann (O’Doherty) (de) Bonniwell; born at Philadelphia, Pa., March 23, I878; educated at Broad Street Academy, Philadelphia.

Moved to Chicago, September I8, I905, as Assistant Chicago Manager for Lamont, Corliss \& Company, of New York City. Resigned November 7, I908, to accept position as General Sale, Manager for John F. Jelke Company. Resigned this position July I, I.9I2, to organize the Charles A. Bonniwell Companr. Married I907 to Zita M. Welch, daughter of Richard I. and Mary A. (Hogan) Welch, of Kankakee, Ill. Born at Slater, Mo., June II, I887.

Children: Evander Charles, born at Chicago, September I3, I908; Donald Raymond, born at Kankakee, I11., November I5. I909; Adrienne Eileen, born at Kankakee, February 22, I9Io; Eloise Marie, born at Kankakee, June I5, I9I4.

Member of Sons of American Revolution; Sons of Revolution; Society of War of I8I2; Sons of Veterans; Marquette Council; Advertising Association of Chicago.

DENT.

Alfred Barbour Dent, of Washington, D. C., was born in Morgantown, West Virginia, on the 4th of January, I86I He was educated in the State Normal School at Bloomsburg, $\mathrm{Pa}$, and Central High School of Philadelphia, Pa. After leaving school he became, at I6 years of age, bookkeeper in the 
Wholesale Grocery of his uncle, Delos L. Holden, at Elmira, N. Y. When Mr. Holden remored to Pueblo, Colo, and became one of the founders of the South Pueblo National Bank, Mr. Dent went with him, and was soon made Assistant Cashier of that institution. At the request of his mother, in I88I, he resigned this position and returned to the east, and after a short service as bookkeeper in an iron mill at Coatesrille, Pa., he bought an interest in the real estate business of M. M. Rohrer, in Washington, D. C., in 1883 . This not proving satisfactory he sold out to his partner, and accepted the position of bookkeeper and cashier for the firm of Barber and Ross, in whose employ he remained for some fifteen years. He left this firm to take a similar position with the Washington Loan and Trust Company, and is now (I9I4) in charge of the Department of Individual Accounts of that Company. He now holds his fifth commission as Notary Public for the District of Columbia : is a menber of LaFayette Lodge No. I9, F. A. A. M.; Sons of the American Revolution, Society of Colonial Wars in the District of Columbia (of which he is Treasurer). Order of II ashington (of which he is Secretary General) and National Genealogical Society (of which he is now an ex-President ). Mr. Dent has long made a study of the scisnce of Heraldry and Armorials and is probably as thorough$1:$ conversant with these subjects as is any man in the country. In I885 Mr. Dent married Miss Sara Melissa March. daughter of Hiram March and Esther (Greenwood) Marsh. his wife, of Coatesville, Pa., and has one child. Dorothy.

Mr. Dent's father, Marshall Mortimer Dent, was County Clerk of Monongalia County for a number of years, was an Editor, a member of the Bar, member of the Richmond Convention of I86I (roting against secession), and later became cne of the founders of the State of West Tirginia. His grandfather, Marmaduke Dent, was a prominent physician. residing in Granville, IV. Ta. His great grandfather, John Dent, was one of the pioneer settlers of West Augusta District, having removed from Loudoun County, Virginia, before the Revolution. He was a Captain of Colonial Militia in the 
wars with the French and Indians and was a Lieutenant in the Ninth Virginia line during the Revolution. Capt. John Dent married Margaret, daughter of Colonel John Evans, of Virginia (who was a descendant of the old Evans family of Wales), and was the first sheriff of Monongalia County. This branch of the Dent family is descended from the emigrant Thomas Dent, Gentleman, who settled in St. Mary's County, Maryland, in about 1650 , for which see Mackenzie"s "Colonial Families."

Mr. Dent's mother, Louisa Amelia (Holden) Dent, was the second wife of Marshall M. Dent, and was daughter to Fox Holden, Esquire, and Harriet (Strong) Holden, of Elmira, New York. She was a woman of education and culture in the highest degree, having held several positions of importance in the educational world. She was at one time Principal of the Female Liberal Institute at Clinton, N. Y.. and in later years Principal of the Women's Department of the Pennsylvania State College. Fox Holden was one of the founders of Elmira, and a prominent merchant of that city for many years. His wife, Harriet Strong, was a descendant of Elder Strong, of Massachusetts, and her line of descent is fully set forth in Dwight's "History of the Strong Family."

\section{DIXON.}

Willis Milnor Dixon was born in New Lisbon, Columbiana County, Ohio, September 5th, I846; the oldest son of Lot Dixon and Charlotte (Converse Cummins) Dixon; was raised in Ohio and Illinois; attended the Public Schools of Beloit, Wisconsin; engaged in the commission business in Chicago in I868; retired and moved to Ohio where he entered the employ of the Pennsylvania Railroad Company in the capacity of a clerk. In 1873 moved to Michigan and was employed as a Station Agent for the Grand Rapids and Indiana Railroad Company; in 1875 returned to Ohio and engaged in the Fire Insurance business. In 1877 he emigrated to Los Angeles, California; 
on the $23 \mathrm{rd}$ day of December, $18 \pi 7$, united in marriage with Regina Mast; remained in California two years; returned to Ohio, and on March 9th, I880, his daughter, Lucile Mast Dixon, was born. He engaged in the Real Estate business and superintended the construction of a business block now know as the Dixon Block in Forrest, Hardin County, Ohio. In I 888 he returned to Los Angeles. California, and has since been interested in the investment of his own capital in subdivisions, mines, and other feasible projects.

He was admitted a member of the Society Sons of the Revolution in the State of California, on Novemher 28, I904, as Number 9I. He was also admitted to membership in the Society Colonial Wars in the State of California, on December 7th, 1904, as Number 63; General Society Number 3689. His insignium of the Society Sons of the Revolution is No. 3648

Lucile Mast Dixon was admitted a member of Escholtzia Chapter, Daughters of the American Revolution, in Los Angeles, Cal., April 3, I906. Her National Number is 55539. She was married to Ralph William Stewart (a Civil-Engineer) October I4, I909, at Los Angeles, who was born March 24, I878, and who was admitted to nembership in the Californix Society Sons of the Revolution, May 3I, I9Io, as Number I 26. Ralph William Stewart was also admitted to membership in the Society of Colonial IVars in the State of California, on February 23rd, I9Io, as Number 8I : General Society Number 4479.

Two children have been born of this union (to date), viz: Dixon Stewart, born November Io, I9Io, in Los Angeles, Calif.; and Ralph IVilliam Stewart, Jr., born March 20, I9I2, in Los Angeles.

Regina Mast Dixon died in Los Angeles, California, July 7 , I9I I.

Willis \ilnor Dixon is at the present time Treasurer and Assistant Librarian and a Director of the California Society Sons of the Revolution; also Treasurer and Director of the Society of Colonial Wars in the State of California. 


\section{HISTORICAL DATA OF CONVERSE FAMILY.}

When William, Duke of Normandie, invaded England, Roger De Coigneries, who was born about Ioro, in the Isle of France, now included in the City Limits of Paris, France. accompanied him as a soldier of fortune and was given landed estate in Durham, England. He was succeeded in his rights by Roger De Coigneries, Second, Roger De Coniers, Third, and he by Galfrid Conyers; the name continues to be called Conyers in England to the present day.

Deacon Edward Convers was born in Wtakerly, County of Northampton, England, January 30, I590; he was the oldest son of Christopher and Mary (Halford) Conyers; he married Jane Clark of Theckenham, England, who died previous to I6I7; emigrated to America in one of the ships that came in the Fleet which accompanied Governor Winthrope, landing at Salem, June I2, I630; he first settled in Charleston, Mass., arid was appointed one of the deputies to lay out the Town of Woburn, Mass., May I5, I640; he was appointed selectman and deacon of the first church of Woburn, and was deputy to the General Court of Massachusetts in I660; he died in Woburn, Mass., August Io, i663.

After coming to America Deacon Edwards changed the spelling of the name from Conyers to Convers, and the American branch of the family have always followed that spelling of the name.

\section{Converse, Edward, I590-1663.}

He came to New England in the ship with Governor Winthrope, landing at Salem on June I2, I630. He lived in Woburn, and in I660 he was Deputy from that place to the Massachusetts General Court.

Converse, James, I620-I7I5.

He came to New England with his father, Edward Converse, and he died in Woburn, Massachusetts.

In King Philip's War he was Lieutenant of Captain John 
Carter's company from Woburn. He was Deputy from Woburn in 1679 to the General Court of Massachusetts.

Converse, James, Jr., I645-1706

(commonly called Major James Converse).

He was born at Woburn, Massachusetts, the son of Lieutenant James Converse. He was Deputy from Woburn, from I679 to I692 to the General Court of Massachusetts, and Speaker in I699, I702-I703. He was Commander at the defense of Storer's Garrison, I69I-I692, and on June Io, I692, he was commissioned Major.

Converse, Josiah Jr., Captain, I684-I77 I.

He was born in Woburn, Massachusetts, the son of Major James Converse. He was Captain of the Woburn Train Band and in I7I5, he was Representative from Leicester to the General Court of Massachusetts.

Converse, Josiah Jr., Lieutenant, I7Io-I775.

He was born at Woburn, Massachusetts, the son of Captain Josiah Converse. He was Lieutenant of the Leicester Train Band and Representative from that place in I733 to the General Court of Massachusetts.

At the time of the Lexington Alarms, April I7, I775, he was in the Town of Stafford, Connecticut, and with three of his sons joined the company from that place commanded by Captain Amos Walbridge, serving in the capacity of First Lieutenant; served for ten days under command of LieutenantColonel Stephen Moulton; he died September IIth, I775.

$$
\text { Israel Converse, Captain, I743-I805. }
$$

At the time of the Lexington Alarms, April I7, I775, he was First Sergeant in Captain Amos Walbridge's Company of Lieutenant-Colonel Stephen Moulton's Battalion; served seven days; was First Sergeant of Captain Rogereno's Third Company, Colonel Joseph Spencer's Second Regiment of Connecticut Line from Nay gth to December I8th, I775. 
He was Second Lieutenant of Captain Abiel Pease's Company, Colonel Samuel Chapman, later commanded by Major Abiel Pease, I776; Twenty-second Regiment Connecticut Militia.

In 1777 he was appointed and commissioned Captain in a regiment being raised and under the command of Colonel Sam McClellan.

In I780 he was appointed Captain of a company in the regiment commanded by Lieutenant-Colonel Levi Wells, raised for the defenses of the Northwest; he died in Randolph, Vermont, June 28th, I8o6.

\section{DUNWODY.}

Major Jefferson Davis Dunwody, deceased, formerly of Kirkwood, near Atlanta, Ga., was born February I2, I86I, and was the son of John Dunwody, born November 6, I8I8. Captain in Nelson's Company of Georgia Volunteers, Jackson's Brigade, Mexican War, and a gallant Confederate LieutenantColonel of the 7 th Georgia Regiment at first battle of Manassas. He married Miss Elizabeth Clark Wing. Colonel John Dunwody was the son of John Dunwody, of Liberty County, Ga., who married at Sunbury in same county June 7, I808, Jane Bulloch, daughter of Captain James Bulloch and Ann Irvine. See Bulloch sketch.

John Dunwody was son of Dr. James Dunwody, who married Mrs. Esther Splatt, widow of Edward Splatt and daughter of Abraham Dean, born I704, and Ann Dupont. Dr. James Dunwody was one of the first physicians to practice medicine in Liberty County, Ga., and was member of the first Executive Council, I776, member of Committee of Safety from St. John's Parish, and qualified as justice of the quorum Angust I9, I776. He went to Georgia in I770, and was a son of 
John Dunwody, who went from Ireland to Pennsylvania in about 1730, and who married in 1740 Susanna Creswell, daughter of IVm. Creswell, of Faggs Manor, Chester County, $\mathrm{Pa}$. The clan Dunwodie had its headquarters in the neighborhood of Dumfries, Scotland. Major Jeff D. Dunwody was a Companion of this Order, and of the Order of the Yellow Rose, composed of those of Royal lineage.

\section{FAIRFAX.}

Arms: A lion passant guardant, sable.

The Fairfax family were seated in Yorkshire, England, in the inth Century.

Fairfaxes of Toulston and America.

William Fairfax, Ancestor of the American Fairfaxes, was the son of Henry Fairfax, second son of fourth Lord Fairfax and Anne Harrison, born October 30th, i69I. He was of Belvoir, Virginia. He married first, Sarah Walker; second, Deborah Clark, of Salem, Mass. He was President of the King's Council in Virginia, and agent for his cousin, Thomas, sixth Lord Fairfax, who was Lord Proprietor, under grant from the English Crown, of all the land in Virginia, between the Rappahannock and Potomac Rivers, comprising about six million acres.

\section{Issue by first wife.}

George William of Belvoir, in Virginia, and Toulston, in Yorkshire; born in the Bahamas in I724; married December I7th, I748, Sarah, daughter of Col. Wilson Cary of Ceelys. near Hampton, on James River, Va. The companion of Washington on his first surveying tour. He died at Bath on April 3, I787, without issue. Anne, the third child of William Fairfax, of Belvoir, Virginia, married on July Ioth, I743, 
Lawrence, elder brother of Gen. Geo. Washington, who died July 26, I752. The issue of this marriage, a daughter, died in infancy. The fifth child of William Fairfax of Belvoir, Virginia, by the second wife, was Brian, eighth Lord Fairfax, of Toulston, in Yorkshire, and Mount Eagle, in Virginia, born in I737. In I759 he married Elizabeth, daughter of Co! Wilson Cary of Ceelys. In I789 he entered holy orders. He was a chief mourner at the funeral of Gen. Washington, who left him in his will the Bible presented to him by the Bishop of Sorlor and Mann. The eighth Lord Fairfax died in August, I802, at Mount Eagle, Virginia.

The eldest son of eighth Lord Fairfax, by his marriage with Elizabeth Cary, was Thomas, ninth Lord of Belvoir, and Vaucluse, Fairfax County, Virginia. He married Margaret Herbert, daughter of William Herbert, Esq., by Sarah Carlyle. He died at Vaucluse, Fairfax County, April 21, 1846. His third son, Orlando, born in 1806 , married Mary Randolph, daughter of Wilson Jefferson Cary of Carysbrook, Fluvanna County, Va. (by Virginia Randolph, sister of Gov. Thomas Mann Randolph, who married the daughter of Thomas Jefferson), May 21, 1829 .

E.thelbert Fairfax, third son of Orlando and Mary Randolph Cary, was born January 20, I845, in Alexandria, Va. He was educated at the Episcopal High School of Virginia. When that institution was broken up by the Civil War, he entered the service of the Confederate States as a lad of eighteen, and was recommended for promotion by Gen. R. E. Lee, in an autograph letter dated Feadquarters, Petersburg, November 8th, I864, who wrote of him, "Mr. Fairfax is a fine youth, who saw much service the past campaign, acting as signal man and courier, on the battle field for Gen. Heth." Mr. Fairfax survived a severe wound received at Bentonville, N. C., March $22, \mathrm{I} 865$. He is the recipient of a cross of honor, being decorated June 3. I9I3. He is now in the Treasurer's Office of the Southern Railway and is second Vice Commander General of Order of Washington. 


\section{FEAMSTER.}

Lieutenant Claudius Newman Feamster, U. S. A., retired, was born in Lewisburg, Greenbrier County, Virginia, on April 25, I876, and is the son of Thomas Davis Feamster; born Noventber 19, I829; died December 31, 1906, and Louisa Madden Cary, born April 8, I844, and grandson of William Cary, Jr., born July 23, I798; died April I, I857 ; and Ophelia Natthews Cary, born December 8, i8I I, died March I I, I866.

Great grandson of William Cary, Jr., born June I9, I760, died October I2, I806, and Maria Barbara Fretchie, born June 20, I777, died May 23, I 834 .

Great grandson of John Cary and Mary Beatty.

William Cary, Jr., was a soldier in the 7 th Regiment of Maryland line from May 21, I778, to August I6, I780.

John Cary was one of Committee of Correspondence of Frederick County, Md., in I775, and on Committee of Observation, same place and time.

Lieutenant Feamster comes of distinguished ancestry and is descended from the families of Cary, Ashfordy, and is a member of the Order of Washington and of the Imperial Order of Ye!!ow Rose.

\section{FRANKS.}

Herbert Marvin Franks was born August 23rd, 1878, at Laurens, S. C. After attending the public schools of that city, he took a course in Mechanical and Electrical Engineering at the Clemson Agricultural and Mechanical College of South Carolina. He is now in the Government service, located at Charleston, S. C. He married Miss Mary Gaillard Hanckel, of that city. 
His father, William H. Franks, took an active part in the Indian Wars in the West, while serving in the United States Army; but upon the outbreak of the War between the Sections he severed his connection therewith and enlisted in the Army of the Confederacy, in which he served during the entire war. During the Reconstruction Period, he played a prominent part in assisting to restore order and white supremacy in Laurens, and adjoining counties of South Carolina; is a descendant of Nehemiah Franks, a Huguenot, who, with his brother Marshall Franks, settled near the present city of Laurens, S. C. They were among the first to locate in that section of the State, moving there from Virginia. By strict frugality and hard work he accumulated considerable land and other property. He lived to be nearly one hundred years of age, loved and honored by all who knew him.

William H. Franks married Nannie M. Ballew, daughter of Rev. Dravid L. Ballew, a descendant of the Huguenot, Leonard Ballou, who was banished from France soon after the "Edict of Nantes." He went to Dublin, Ireland, married Esther Meredith, daughter of Rice Meredith, a Scotch-Irishman; he, with his wife, emigrated to America and settled in Virginia.

Rev. David Lester Ballew, married Eliza Louisa James, born September 9th, I80I, fifth child of Benjamin James, who served as a private soldier in the South Carolina Continental line from January Ist to July Ist, I 783 .

Benjamin James, married March I3th, I794, Jane Stobo, born June 4th, I764, daughter of Richard Park Stobo, who married November 24th, I757, in St. Andrew's Parish, Berkeley County, South Carolina, Mary Harvey. Benjamin James was the son of Hon. John James, a Justice, November 8th, I773, in Stafford County, Virginia, who married Ann Strother, of an ancient Virginia family, descended in the direct line from the Masons of Gunston, Waughs, Thorntons, Savages, Thoroughgoods, and other prominent families of Virginia.

Hon. John James, according to tradition, was descended from the Washingtion family. The name of James is found among the very early records of the "Old Dominion." 
We find that Jane Stobo, who married Benjamin James, was the daughter of Richard Park Stobo, son of James and Elizabeth Stobo. James Stobo, Esq., a planter in South Carolina, was born in I705 and was of St. Andrew's Parish.

He was the son of Rev. Archibald Stobo, who arrived in the year I700 in South Carolina, after the failure of the noted "Darien Scheme." He was a graduate of the University of Edinburgh, Scotland, June 25th, I697, and married there July 9th, I699, Elizabeth Park, daughter of James Park, writer, who married Iean Scot.

Rev. Archibald Stobo was instrumental in establishing the first Presbytery in the Colony of South Carolina, the Circular Church in Charlestown, The Bethel Presbyterian Church, Pon Pon, near Walterboro, the Wilton, Edisto, and Cainhoy Churches, to all of which he was a faithful servant from I7IO to 1728 , dying in 1740 . He was a fearless, upright and prominent citizen in the province and has left many descendants.

\section{GERALD.}

Herbert Parvin Gerald, born July 8, I858, Camden, N. J.; educated at Centenary Collegiate Institute, Hackettstown. N. J., I875-1878, and at Wesleyan University, Middletown, Conn., I878-I882; received degree A. B. at Wesleyan, I882, and A. M., I885; member of Psi Upsilon College Fraternity and of Phi Beta Kappa; studied law in Columbia Law School, New York, 1882-3; and again in Georgetown University Law School, Washington, I889-90, taking degree LL. B. at latter, I890; taught in Preparatory School for Lehigh University. Bethlehem, Pa., I883-5; clerk in Fish Commission at Washington, I885-8; in War Department, I888 (Mch.-Sep.) ; and Assistant Examiner in U. S. Patent Office since I888; married 
December I6, I890, at Washington, Mrs. Kate Towson Brown (born March I7, I850, daughter of James Edward Towson. I808-1888, of Stafford Court-House, Va., and his second wifa, Agnes Ann Suttle; and widow of Dr. Aurelius Preston Brown, 1832-I883, of Upperville, Va.) ; no children.

Member of Order of Washington,' Society of Colonial Wars, Sons of American Revolution, National Genealogical Society, University Club, Phi Beta Kappa Association, Osiris Lodge of Freemasons (Secretary since I895); Mt. Horeb Chapter, R. A. M.; Albert Pike Consistory, $32^{\circ}$, Scottish Rite; all of Wiashington, D. C., and several other societies and clubs.

Most of his ancestors since I700 have lived in Cumberland County, N. J., at or near Bridgeton, which has been his legal residence since I866; and many of them came there from Southampton and Easthampton, Long Island.

This Cumberland County was originally a port of Salem County, and was set off therefrom as a separate county by Act passed January 19, I748; while Fairfield township in this County was established by Act passed May i2, I697.

His surname, derived from FitzGerald, has been variously spelled (in over 60 ways in his home county since r700). He changed it from "Jerrell" to "Gerald" in I 893.

His parents are: William Jerrell, born November I2, I 825 , Haleyville, N. J.; Sea-captain I $857-85$; dealer in coal and ice at Bridgeton since I886; City Councilman, I887-90; and Cornelia Stratton Parvin, born July 25, I838, Fairton, N. J., who were married December I7, I856. He died June 6, i91 5.

Grandparents: Jeremiah Jerril, I807-1884, and Elizabeth Ann Devinney, I8I I-I854, married I832.

Fithian Stratton Parvin, I8Io-1870, and Mary Ogden, I8IoI897, married 1833 .

Great grandparents: Zachariah FitzGerald, died I837, and Judith Corson, died I8I3, married I796.

Daniel Devinney and Rhoda Bowen, I783-I86r.

Daniel Parvin, I770-I857, and Elizabeth Sutton, I774-I859, married I792. He was member of New Jersey Assembly 
ISI6 and IRIE, a Chosen Freaholder, and long Iustice of the Peace in Fairfield.

Benjamin Ogden, I788-I8I6, and Mary Houseman, I785I870, married I806.

Great, great grandparents: John Bowen, died 1785 , and Gertrude Blew.

Josiah Parrin, died 1785 , and Sarah Stratton.

Thomas Sutton and Edith Abbott, sister of Rev. Benjamin Abbott, I732-I796. a famous primitive Methodist preacher in Southern New Jersey. He was son of Benjamin Abbott and Hannah Burroughs (daughter of John Burroughs, of Hunterdon County, N. J.), and grandson of James Abbott, from England, who settled on Long Island.

James Ogden. I753-I822, and Ruth Ogden, I77I-I85I (daughter of his uncle. Thomas Ogden). married 1786 . In I $7-6$ Tames Ogden rolunteered, and serred through the Rerolution as Sergeant, Quartermaster. Lieutenant, and Captain in New Jersey Militia, and was engaged in battles of Trenton. Princeton, and Monmouth. After this he was Colonel of First Regimant. Cumberland Brigade. He was also Iustice of Peace and Freeholder for Fairfield.

John Houseman, died I823, and Miriam Woodruff, died I80.3. He was Captain in Salem County, X. I.. Militia in the Revolution.

This Woodruff line connects back through Ebenezer and Miriam Woodruff (he died I/55). Nathaniel Woodruff (died $1 ; 26)$ and tbigail Leek (daughter of Ebenezer Leek), Ioln Woodruff. Ir. (died I 703 ) and Hannah Newton. John Wood-

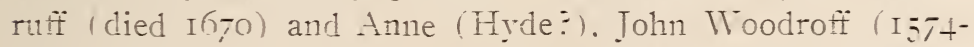
IfI I and Elizabeth Cartwright. Robert Woodroff (died I6II) and Alice Russell, and William Woodroff (died I58\%). to Thomas Woodrocre, of Fordwich. England, who died I 552.

Great. great, great grandparents: Josiah Parrin, died I76r. and Susanna Holmes. He was Freeholder for Hopewell, and Ruling Elder in Deerfield and Greenwich Presbyterian Churches.

William Stratton, I705-1/59. and Phebe Fithian. 
John Ogden, I706-I759, and Bathniphleoth Crosthwayt, I7I3-I787 (her first name is Hebrew for "Daughter of Wonders"). He was Captain of Fairfield Militia in I748; also Judge of Common Pleas, Justice of Peace, and Deacon in Fairfield Presbyterian Church.

Thomas Ogden, I720-I785, and Sarah Austin, I730-I804; married i76ı. He was Freeholder for Fairfield during Revolution, and Ruling Elder in Church.

Great, great, great, great grandparents: Thomas Parvin, I663-I743, and Rebecca - He was first Parvin immigrant (from Southampton, Long Island. about I700) to this Fairfield, N. J., region, and ancestor of all Parvins in South Jersey. He was Overseer of Roads and Surveyor of Highways, a weaver and farmer, and of Huguenot descent. Both he and his son, Josiah Parvin, were soldiers in the Colonial Militia in I7I5.

Jonathan Holmes, I668-I7I 5, and Susanna Miller, died I749, (daughter of John Miller, died I699).

Benjamin Stratton, died I7I6, and Mary —. This Stratton line goes back through Richard Stratton (I6I9-I675) and Elizabeth Edwards (died I705, daughter of Wm. Edwards), William Stretton (I585-I647), and John Stretton, to William Stretton, of Shrevenham, Eng., who died 1604.

Jonathan Fithian, died I743, and Sarah —- He was Assessor, Freeholder, Justice of Peace, Judge of Common Pleas; also Elder in Fairfield Presbyterian Church, and soldier in Colonial Militia.

John Ogden, I67I-I745. He was first Ogden immigrant, I696, from Fairfield, Conn., to Fairfiield township. Salem County, N. J., and ancestor of nearly all Ogdens of South. Jersey. He was Assessor, Freeholder, Justice of Peace, Elder in Presbyterian Church, and Lieutenant in Colonial Militia in I7 5 . In I704 he married Mrs. John Fithian.

Great, great, great, great, great grandparents: Obadiah Holmes, I664-I723; born Salem, Mass., came to Greenwich, N. J., by 1685; was Justice of Peace and Judge of Salem County Courts. He was son of Reverend Obadiah Holmes, 
I605-I682, who was born at Preston, Eng., son of Robert Hulme; came to Boston, I638, was Representative Rhode Island, I656: member of Special Governor's Council in King Philip's War, and second Pastor of Baptist Church at Newport, R. I., from I652 till his death.

Richard Ogden, I6ı-1687, and Mary (probably his second wife: his first was Mary Hall), born at Bradley Plain, Hampshire, England; came to America in I640 with his brother, John Ogden ( I609-I682, ancestor of "Elizabethtown Ogdens") ; lived at Southampton, Stamford, and Hempstead, and settled at Fairfield, Conn., about $165^{6}$, being town miller there from I662 till his death. He was a first cousin of "John Ogden of Rye" (I600-I682, also prominent in early Connecticut history) ; and with his brother, "John Ogden, of Elizabeth" ( I609-I682), this Richard Ogden built for Governor Kieft in I642 the second Dutch Church (of stone, within the fort) in old New York City.

This Ogden line runs back through Richard Ogden (born I568, married 1592) and Elizabeth Huntington (daughter of Samuel Huntington and Margaret Crane), Edward Ogden (born 1540, married I563) and Margaret Wilson (daughter of Richard Wilson), William Oakden and Abigail Goodsall (married I539, daughter of Henry Goodsall), and Richard Okeden and Mabel de Hoogan (daughter of John de Hoogan), to Robert Okeden, of Nutley, Hampshire, England, in I453; and this Robert Okeden is Mr. Gerald's oldest discovered Ogden ancestor, though the Ogden family in England goes back to the time of IVilliam the Conqueror.

\section{GORDON.}

Daniel Smith Gordon married Frances Pinkney White, daughter Reverend John Campbell White, of Baltimore, Md.; son of Daniel Smith Gordon, I8II-I885, and Amanda Elizabeth (Burroughs) Gordon, I833, living I9I3. Daniel Smith Gordon, Sr., son of Henry Gordon, I785-I859, and Elizabeth 
(Smith) Gordon. Henry Gordon, son of George Gordon, I758-I809, a Revolutionary War soldier; son of Henry Gordon. I734-I809, a Revolutionary War soldier and slave-holder by Cumberland County, Pa., tax records; son of George Gordon, died I759, son of Alexander Gordon, died 1749, who came to Franklin County (then Cumberland County, Pa.), and settled in 1734 .

Elizabeth (Smith) Gordon, daughter Daniel Smith, I755I839, a Captain in Revolutionary War, Frederick County, Md., troops. Slave-holder by census I790; son of George Smith, who came to York County, Pa., about 1740 and moved to. Frederick County, Md., I755.

Amanda E. (Burroughs) Gordon, daughter John Amory Burroughs, I802-1872, of St. Mary's and Charles County, Md., and Eliza Temperance (Dent) Burroughs, I8IO-I88I ; son of Norman Burroughs, I760-I809, a soldier in Revolutionary War, Maryland troops, and slave-holder by census 1790 .

Eliza T: Dent, daughter George Dent, I757-I842, Captain Revolutionary War and I8I2 War, Maryland troops, slaveholder by census I790; laid corner stone Court House at Leonardtown, Md., St Mary's County, I83I; son Thomas Dent, died I 775 ; son of John Dent, son of John Dent, died I7I2, who came to Maryland, I66I ; Captain Indian Wars, "Gent" witness against Fendall, I68I. Member King's Council for Maryland; appointed by King William, I69I ; Vestryman King and Queen's Parish; Member Committee for St. Mary's County, Md., I689; owner Cool Spring Manor, etc., etc.

Daniel Smith Gordon, Jr., Orator, Essayist and Historian, born Washington, D. C., brought up Fairfax County, Va.; educated Randolph Macon College, Va.: member there Franklin Literary Society and Phi Kappa Psi Fraternity and an officer in same; member following societies: Nat'1 Soc. Scions Colonial Cavaliers and Dep. Gov. Gen'l of same: Maryland Society of New York and Trustee of same; Order of Washington and Vice-Commander of same; National Genealogical Society and Councillor and Editor of same; Columbia Historical Society. 
Clubs: Richmond, Richmond, Va.. Westmoreland, Richmond, Va. Baltimore, Baltimore, Md. Southern, New York City.

In I892, by newspaper and other agitation, had price of bread reduced in New York one cent per loaf.

In 1909, in same way, had storage of eggs investigated and as a result the New York Pure Food laws had many offenders fined and imprisoned.

Present address: Colorado Building, Washington, D. C.

\section{GRIGSBY .}

Hart Preston Grigsby, deceased, son of John Warren Grigsby and Susan Preston Shelby, son of Joseph Grigsby and Mary Ashley Warren Scott, son of John Grigsby, Captain I 3th Virginia Line, Revolutionary War, and Rosanna Etchison, son of John Grigsby and Jane Rosser.

This John Grigsby was Captain with the forces of Admiral Vernon in the expedition against Cartagena, I740.

\section{HABERSHAM.}

Edward Heddon Habersham was born in Annapolis, Maryland, and is the son of Alexander Wylly Habersham, an officer in the old U. S. Navy, who married Jessie Steele, of Annapolis, Maryland, a granddaughter of Francis Scott Key.

Alexander Wylly Habersham was the son of Hon. Richard Wylly Habersham, of Georgia, a member of Congress, and Sarah Hazzard, daughter of Captain Barnard Elliott and Catharine Hazzard, a descendant of the ancient family of Hazzard, of South Carolina. Hon. Richard Wylly Habersham was the son of Hon. James Habersham, Rebel Financier, who held other positions in Revolutionary days and after that period, and who married Esther Wylly, a sister of Col. Richard Wylly, of Revolutionary War and of Alexander Wyll $\%$, of Coleraine County, 
Ireland, who had been Speaker of Colonial Assemby of Georgia and Secretary of Governor's Council before the Revolution. Hon. James Habersham was the son of Governor James Habersham, member of his Majesty's Council and acting Governor of Georgia, who went to Georgia about the year I740. He married Mary Bolton, sister of Robert Bolton, of Savannah, and daughter of Robert Bolton, of Philadelphia, Pa., Church Varden of Christ Church Parish, of that city.

As the Bolton lineage has been fully given in the articles on Bulloch, McBryde and others, we will proceed to give a short sketch of the eminent Georgia family of Habersham, from whom descends several of our companious of this Order. The names of our members who descend from this old Georgia family are the following: James Nephew King, and his brother, C. IV. King, of Rome, Ga., Col. G. Noble James, of Savannah, Ga., and many others who are not companions of this Order.

The progenitor of this illustrious Georgia family was James Habersham, who went from Beverly, Yorkshire, England, to Georgia about the year I740, and who took a very prominent part in the affairs of the Province, occupying many positions of prominence, such as Secretary of the Province, President of the Upper House of Assembly or King's Council and acting Governor of Georgia. He married Mary Bolton, daughter of Robert Bolton, of Philadelphia, Pa., who was himself an Englishman from an ancient family and who, in Philadelphia held several important positions in the Parish of Christ Church. He married Ann Clay, widow, and daughter of Winlock Curtis, son of Hon. John Curtis, of Penns Council. Hon. James Habersham and Mary Bolton had three sons: Hon. James Habersham, who took part in the liberation of the Colonies, from whom descend branches of the families of Elliott, Milledge, Barnwell and others, and Lieut. Col. Joseph Habersham, of the Continental line, and Postmaster-General of the United States, and Major John Habersham of the Continental line of Georgia Brigade, who was President of Executive Council in Georgia. From these three patriots descend many families well known in the country. 


\section{HAMILTON.}

F. M. Hamilton, Freight Traffic Agent for the Seattle Division, Puget Sound Traction, Light \& Power Company, was born at Grafton, W. Va., O.ctober I5th, I875, received a graded and high school education and continued his studies under a private tutor.

Studied medicine for two years, but gave it up and entered the service of the Baltimore and Ohio Railroad. From 1900 to I905 was with the Jones and Laughlin Steel Company, Pittsburgh, Pa., who own and operate the Mon. Con. R. R., successively filling the position of Yard Master, Ass't Train Master, Special Agent, and Chief Clerk to Gen'] Supt., resigning to become Manager of the American Car Tracing and Shipping Company, a private traffic organization. Removed to Seattle in 1907 and worked jointly for the Northern Pacific Railroad and the Pacific Northwest Demurrage Association, resigning to accept the appointment of Traffic Manager for the Alaska, Yukon, Pacific Exposition. At the close of the Exposition, became Assistant Sales Agent for the Roslyn Fuel Company, covering the States of Idaho, Oregon and Washington.

Mr. Hamilton was appointed to his present position September Ist, I9II.

He is the son of Dr. J. M. Hamilton, of Virginia, and Laura Louise Moser, daughter of Dr. Philip Moser, a man of prominence in South Carolina, whose ancestor, Philip Moser, came over in the ship Osgood to Pennsylvania and was qualified in $175^{\circ}$.

Dr. Philip Moser married Charlotte Wilcox, daughter of Samuel Wilcox and Anna Stobo. The family of Wilcox were of New York.

Anna Stobo was one of the daughters of Richard Park Stobo, who married on November 24, I757, Mary Harvey. $\mathrm{He}$ was the son of James Stobo, planter, son of Rev. Archibald Stobo, a graduate of the University of Edinburgh. June 25. I697, and who went as a minister in I699 with the colo- 
nists to settle at Darien on the Isthmus of Panama. As history relates, this scheme of settlement was a failure due to a variety of causes, and so the Colony, after many hardships, abandloned the location. But few reached a place of safety, as the ship Rising Sun upon which were embarked Rev. Archibald Stobo and wife, seemed to have been saved by a miracle, for only those who went up to Charleston, S. C. in a small boat escaped destruction, as the ship Rising Sun was blown away to sea, and all on board were lost.

The Rev. Archibald Stobo was one of the prominent men in the Colony, not only being one of the founders of the first Presbytery in the Province, but the minister of many churches. His sons also occupied positions of prominence, for James Stobo was elected as a member of the Commons House of Assembly, January, 1728, but as he was a non-conformist, the Council rejected him and others because he would not Conform. He was a landowner and planter in the Province. His brother, Captain William Stobo, went with the South Carolina Colonial Troops upon the famous expedition against St. Augustine in 1740 .

Later on we discover two more of the family, who were defenders of their country against the Mother Country, for in a list of American prisoners in Mill Prison at Plymouth, we discover Lieutenant Jacob Stobo among the prisoners in 1782, and we find that James Stobo was a private in Captain Charles Drayton's Company 26. August, 1775. See Vol. 10. page 123, and Vol. XII, page 187, S. C., Historical and Genealogical Magazine.

The Stobo family, though extinct in male line was allied with many well known names in South Carolina. and the Rev. Archibald Stobo and Elizabeth Park, his wife, have many descentants in America. See Bulloch and Franks.

Anna Stobo, daughter of Richard Park Stobo, married Samuel Wilcox, Esq.. son of Sir Thomas Wilcox, of High 
Cross, Tottenham, Niddlesex County, England, at the family plantation, "Wilton," South Carolina, December 9, I790; ceremony performed by Rev. Thomas Frost; issue:

I. Charlotte Sophia, married Dr. Philip Moser, afterward, Dr. Screven (no issue by second marriage).

2. Anna Maria, married George Scriba, of New York.

3. Laura Louise, Married Benjamin Munıford, of New York.

4. Henry Pinckney, died while studying for the Episcopal ministry.

Charlotte Sophia, eldest dlaughter of Anna Stobo and Samuel Wilcox, married Dr. Philip Moser, July 5, I827, at New York City, Rer. Benj. T. Onderdonk, of Trinity Church, officiating; issue:

I. Pliilip Stobo, born July I7, I829, married twice; isslie by both. Died September 26 , 1904.

2. Laura Louise, born May 3, I833, married Dr. J. M. Hamilton, of Virginia, March 25, I852, at Philadelphia, Pa.; issue. Died August 3I, I898.

3. Eliza Burgoyne, born February I7, I835, married Col. Janes T. Locridge, June 2, I854: issue. (Still living.)

Laura Louise Moser, 2nd child of Dr. Philip Moser and Charlotte Sophia Wilcox, married at Philadelphia, Pa., Dr. J. M. Hamilton. (See above); issue:

1. Philip Stobo, born May 4, I853, married Caroline Hutton; issue.

2. Chas. Melvin, born May 6, I856, died October 5, 1856 .

3. James Melvin, born Septemb॰r. I8 87 , married Cora Utterback; issue.

4. Abraham Hutton, born - 1858 , died in infancy.

5. Jefferson Davis, born June, I86I, married Lillie McWilliams, at Grafton, IV. Ta.; issue.

6. Oliver Osborne, born August 23, I864, married Lizzis Ballantyne, at Grafton, W. Va.: issue.

7. Charlotte Alice, born April 2I, I869, married Harry L.ong, of Grafton, W. Va., at Brooklyn, N. Y.; issue.

8. Lillie Sophia, born June I, I870. married Milton Dayton, at Grafton, WV. Tra.; issue. 
9. Charles See, born ——, I873, died three weeks later.

IO. Frederick Moser, born October I5, I875, married Daisy Louise Glenn, at Pittsburgh, Pa., February 4, I904. Issue: Louise Graham, born March 26, I905, and Kathryn Jane, born January I9, I9Io.

I I. Pinckney Wilcox, born ——, I877, married Helen Craw ford, at Pittsburgh, $\mathrm{Pa}$.; issue.

According to the record in the old German bible, now in the possession of the widow of Philip Stobo Moser, Cedar Rapids, Iowa, Philip and Sophia Moser were born in Germany in I735, which is to say the least, rather indefinite as it is hardly probable that they were both born in the same year, though not impossible. It makes no reference to the wife's maiden name. However, through the kindness of IV'm. Henry Egle, M. D., who at the time he wrote (I897) was State Librarian of Pennsylvania, John Philip Moser arrived at Philadelphia on the ship "Osgood," Capt. William Wilkie, from Rotterdam, and was qualified September 20th, I750. In a latter from Rev. David Van Horne, pastor of the Race Street German Reformed Church (dated Philadelphia, September 4th, I878), he states that the following entries were found in the minute book of the consistory or board of corporation:

"January IIth, I768. A meeting of the congregation was held to elect trustees, elders and deacons. Philip Moser was elected Elder by 39 votes."

"January I4th, I77I. Philip Moser was elected trustee by 38 votes."

"An estimate for building a new church was presented to the congregation by the board of corporation, dated July ist I77I, signed by Philip Moser as one of the trustees."

In the first census of the United States the names of several Mosers in and around Philadelphia are found.

Not many years ago a very large estate in Schuylkill Count: Penna., involving coal lands held by the Lehigh Valley Co., was contested by the heirs of Peter, George and Burkhart Moser. For some reason, no effort was made by the family to look 
into the matter, and it is not known what the outcome was, or whether Philip Moser was related to this branch.

The children of Philip and Sophia Moser were:

I. Elizabeth Moser, born November I6, I754, married Jacob Bonvier, issue.

2. Catherine, born March 20, I756, married Rev. Boehme, afterward Chas. Lewis.

3. Susannah, born July, I758, died six months later.

4. Varonica, born July, I759, died January, I760.

5. Francis, born July 27, I760, married George P. Keyport.

6. Charlotte Sophia, born August 22, I762, married ( I) Mollihan, then (2) T. Brundige.

7. Mary, born January I2, I764, died one year later.

8. Sisan, born August, I762, married Wm. Young.

9. Philip, born December I6, I770, married first a Miss Talcott, of South Carolina, by whom he had two daughters, one of whom married a Mr. Green, the other married Dr. Burgoyne. Philip Moser, after the death of his first wife, married Charlotte Sophia Wilcox, daughter of Anna Stobo and Samuel Wilcox, July 5, I827, at Trinity Church, New York, Rev. Benj. Onderdonk officiating.

Io. Chas. Lewis, born J11ne 25, I772.

I I. Samuel, born February 23, I775.

I2. Amelia, born January 29, 1778, married Wm. Montgomery. With the exception of Philip Moser, the record shows that all of these children were dead prior to March, I830. Philip Moser, 9th, child of Philip and Sophia Moser, was the materal grandfather of F. M. Hamilton, she being the second child of his marriage with Charlotte Sophia Wilcox, daughter of Anna Stobo and Samuel Wilcox. He received a medical diploma in I788, showing his diligent attendance at three courses of lectures, at Philadelphia; this is signed by $\mathrm{Wm}$. Shippen. He evidently removed to South Carolina shortly after receiving his degree, and remained there until the year I83I or '32. He took an active part in the affairs of South Carolina. He was twice elected to the State Senate, and passed a bill known as the "Moser Bill" prohibiting dueling. He was a close personal friend of Governor Charles Pinckney. 
On July 28, I798, he was appointed by Governor Pinckney Surgeon to the Cavalry Regiment annexed to the Seventh Brigade, where he served for seventeen years, resigning March 29, I8I6. He took some part in the war of I8I2. He was also nominated for Governor of South Carolina, and was defeated by only a trifling majority.

Having lost all papers relating to my father's family, my information is very meagre and only extends to my Grandfather Hamilton. I dimly remember my father telling me that his father's family came from the North of Ireland, and settled in Virginia in the very early days of the colony. My grandfather's name was Charles Hamilton, and he married Alice McGuffand or McGuffin; they lived in Bath County, Virginia. I cannot say with certainty how many children they had, but remember:

I. Oliver Osborne.

2. Rebecca.

3. James Melvin (my father).

4. Gawin.

5. Charles.

In the record of officers and soldiers of the revolutionary army, I notice several Hamiltons from Virginia named Charles, James and Gawin, and I think it very probable that some of them at least are my ancestors.

Dr. J. M. Hamilton, was educated at the University of Virginia and received his medical diploma from the University of Pennsylvania, at Philadelphia. He was an ardent adherent of the Southern cause and was sadly persecuted for aiding, both financially and morally, the secession. An instance of the open defiance of my parents can be noted in the naming of their fifth child, who was born in I86I, Jefferson Davis. My father never recovered from the losses sustained by the war and died comparatively poor. 


\section{HARDEN.}

Edward Thomas Harden, born Savannah. Ga., October II, I853, son of Edward Jenkins Harden and Sophia H. Maxwell, son of Thomas Hutson Harden and Natilda A. Baker, daughter of John Baker and Mary Lapine, born Jones, son of Benjamin Baker and Susanna.

Benjamin Baker, Volunteer under Oglethorpe in I740, against Spaniards, pioneer, early settler and landowner of Georgia, and John Baker, member Georgia Council of Safety and Colonel Liberty County Georgia Militia, Revolutionary War, etc.

\section{HASKINS.}

Caryl Davis Haskins, born Waltham, Mass., May 22, I867, son of John P. Haskins and Helen P. Davis, grandson of Roswell W. Haskins and Eliza Snith Caryl, son of John Haskins and Sarah Wilson, son of William Haskins, Massachusetts Militia and Continental Army, Revolutionary War, and Joanna Hackett, son of John Haskins and Betsy Cole.

William Haskins, Revolutionary ancestor, was killed at Yorktown. lohn Haskins. Colonial ancestor, held various local offices in towns of Shutesbury and New Salem, Mass. Large land owner.

\section{HART}

William Lee Hart. born Yorkville, S. C.. January 27, I88I. Son of George Wrashington Seabrook Hart and Helen Almene 
Hackett, son of Oliver James Hart, M. D., and Joanna Adelila Townsend, son of William Rogers Hart and Sarah Clark, son of Rev. Oliver Hart and Anne Maria Grimball (Sealy), son of John Hart, Jr., and Eleanor Crispin, son of John Hart, Sr., and Susanna Rush.

Rev. Oliver Hart, I723-I795, Chaplain, Continental Army, S. C. Special Commissioner to back country in 1775 .

John Hart, Sr., Nember first Pennsylvania Assembly from Philadelphia.

John Hart, Jr., Sheriff, J. P., etc.

\section{HEATH.}

John Heath was born in Oakland, California, the son of John Heath and Blanche Thayer Meeks. He is the direct descendant on his father's side of Col. William Ball, the ancestor of Martha Ball Washington, of Capt. Charles Ewell and of Col. Richard Lee, the founder of the Lee family of Virginia, and on his mother's side of William White of t':e Mayflower, of Rev. Jean Bruneau, Sieur de Moulinar, one of the founders of New Rochelle, of the Comte de Jolie, of Ralph and John Prescott, who were the direct descendants of Henry I of France, and David I of Scotland and many other illustrious ancestors. Many of them were officers in the War of the Revolution, as well as in the Colonial Wars.

$\mathrm{Mr}$. Heath has spent most of his life in traveling abroad. In 1900 , he went to Europe and lived in Germany for four years, studying music and languages, afterwards returning to California. In 1908, he went abroad again, this time studying in Switzerland and in Italy. On returning to the United States he spent a year at the University of Virginia, and then 
after a short trip in Europe returned to California, where he continued his study of Ariation. In I9I3, he was in Hawaii, and in I9I4 went to South America as one of the six Delegates from the United States Universities to the Fourth International Congress of Students at Santiago, Chile. Mr. Heath is now living in Washington. D. C., where he is studying International Law. $\mathrm{He}$ is an Alumnus of the University of Virginia, of Leland Stanford University in California, a member of the Class of I9I 5 of George IVashington University, a member of the Colonnade Club of Virginia and one of the founders of the Aero Club of Virginia, and also a member of the American Historical Association. and the Scions of Colonial Cavaliers.

John Heath, born Oakland, Cal., April II, I892, son of Iohn Heath and Blanche Thayer Meeks, son of Richard William Heath and Mary Elizabeth Allen, son of John Ileath and Elizabeth Deakins, daughter of Colonel James Ewell and Mary Ewell, daughter of Solomon Ewell, son of Captain Charles Ewell and Sarah Ball.

James Ewell. Member Committee of Safety, Prince William County, Tirginia, Major Revolution, died I809. Captain Chas. Ewell, I713-1756, Vestryman, Commissioner of Peace, Church Varden, Member Virginia Grand Jury, etc.

HETH.

Captain Stockton Heth, of Confederate States Navy, was born in Richmond, Ta., April 5, I839, and is the son of Lieutenant John Heth, of U. S. Navy, who was with Commodore Decatur when he was captured by the British and carried to 
Bermurla. Lieutenant John Heth married Margaret Pickett. He was the son of Henry Heth and Anne Hare, son of Henry Heth, born in Ireland on the I6th of November, I7I8, and died in Pittsburgh, Pa., June I2, I793. He married Agnes Mackay.

Thiree brothers, William, John and Henry Heth served as officers in the War of Independence and were charter members of the Society of the Cincinnati. Henry Heth was Captain and then Major of Ist Virginia Regulars in the Revolutionary War.

We find the following under Heath and Heth: Captain John Heth, Vestryman of Wicomico Parish; John, son of John, Member of House of Burgesses, Northermberland County, Va. ; Colonel Henry Heth, elector, I758, Alphabetical List of Poll in Maryland.

\section{HILL.}

I. John Hill, from Northamptonshire, England, as early as I654. settled in Guilford, Conn. He had married in England a wife, Frances, who died in May, I673, and he married as second wife, September 23, I673, Catharine Chalker, of Saybrook. He died June \&, i689.

2. His son. James Hill, born in England, May I5, I646, married Sarah, daughter of Michael Griswold, September, I682. He died October 8, I707, and his wife May 8, I729. He settled in East Guilford (now Madison), Conn.

3. His son, Daniel Hill, born in East Guilford, June 8, I692, married, April 20, I7I4, Murdwell, daughter of Obadiah Wilcox. He died January 20, 1745 , and his wife February 3, I770. Thev were buried in Madison. 
4. His son, Reuben Hill, born in Madison, March I, I7I5I7I6, was twice married, first to Mercy Jacobs, in I746, who died February 6, I776, and second to Dorcas (Way) Murray, widow of Jonathan. She died November 24, I794, aged 78, and he rlied November I7, I804.

ITis son, Reuben Hill, by his wife, Mercy, born February 25, I746-7, died September 23, I835. Served in the Revolution as Coast Guard at Provincetown, Mass., and also in the I,cxington Alarm. He married February I7, I774-5. Hannah, danghter of Noah Scranton, born October 27, I752, died March 20, I833. Residence, Madison, Conn.

6. His son, Julins Hill, born November 2, I774, died December IO. I852. He married January 3, I80I, Mary Ann, daughter of Hugh and Olive (Sage) Brown, born November I, I780, died December 3, I855. He was Quartermaster of the East Guilford Coast Guard during the War of I8I2. Residence, Madison, Conn.

7. Benjamin Scranton Hill, son of Julius, born in Madison, August I6, I8I5, died in New York City, January I8, I895, married March 28, I846, Elizabeth Stokes Jones, daughter of Joseph Bolles and Eliza (Stokes) Jones, born Orange Court House, Va., May I5, I824, died August 20, I905. Residence, New York City.

8. His son, Edwin Allston Hill, born in New York City, January I8, I850, married June I8, I884, Ida M. Wood, of New Haven, daughter of Alonzo F. and Rachel (Hodges) Wood.

(Following is condensed from American Biographical Directory, D. C., I908-9:) Lawyer, Civil Engineer and Chemist. Yale University degrees of A. B. and M. A. and Columbian University M. S. and Ph. D. Seventeen years railway service as lawyer, civil engineer and operating official. Member of the bar in New York, Connecticut, District of Columbia and Supreme Court of United States. Railway offices held were Assistant Attorney. Assistant Superintenden:, Claim Agent. Real Estate, Tax, Industrial and Insurance Agent. Chief Engineer and Assistant Receiver with N. Y. N. H. \& I. R. R., Big Four, Jacksonville Southeastern, and other 
roads, Private Secretary to the Commissioners of Patents. At present a First Assistant Examiner in the Patent Office, also Assistant Professor of Chemistry in George Washington University. Nember of various of the Inaugural Committess, membersinip now or formerly in American Society of Civil Engineers, American Chemical Society, Western Sociaty of Engineers. Connecticut Society of Civil Engineers, Illinois Society Civil Engineers, Engineers Club of Cincinnati, Alumni Associations of Yale and George Washington Universities, Society of Mayflower Descendants in Connecticut and the District of Columbia, Sons of the American Revolution, etc.

\section{HITCHCOCK.}

Frederick Hills Hitchcock, born Boston, Mass., July 4, I867. Son of Thomas Barnes Hitchcock and Sarah S. Hills.

Son of David K. Hitchcock and Abigail H. Barnes.

Son of Hollis Hitchcock and Mary Ward.

Son of David Hitchcock, Captain Revolutionary War, and Martha Keyes.

Son of Peletiah Hitchcock and Sarah Parsons.

Son of Captain Luke Hitchcock, Member General Court of Massachusetts, etc., and Sarah B. Dorchester.

\section{HOLDEN.}

Henry Prichard Holden, although a native of Cincinnati, the "Queen City" of that State felicitously and facetiously termed "The United States of Ohio" and "Stepmother of Presidents," lived in early childhood and youth in New England, and was educated chiefly at private schools in Hartford and Farmington, Connecticut, Lenox and Groton, Massachusetts, and Exeter, New Hampshire. He began his collega 
conrse at Yale, completing it at Michigan University, soon afterward taking up the profession of the law; but that destiny which "shapes our ends, rough hew them how we will," nipped his legal aspirations in the bud and landed him in the newspaper field. There he filled varied positions from "cub" reporter to eflitorial writer (Detroit. Mich., Albany and Troy, N. Y., and Indianapolis and Fort Wayne, Ind.), and was special correspondent for Cincinnati, Chicago and New York papers, and an occasional contributor to magazines.

Lured by the slogan "short hours and steady jobs," he entered the L. S. service via the Bureau of Pensions, in I88I; and to the present time has personally demonstrated the trutl of that slogan.

His affiliations with societies and clubs has been varied, including literary and social ones, and "frats" of school and college. Among these the National Geographic Society, Social Science, Unity (Cincinnati and Washington), Monday Evening Club, Short Story Club, Liberal Union, Men's Club (All Souls' Church, Washington), The Ohio Society, Die Deutsche Dramatische Gesellschaft, and the patriotic societies Sons of the American Revolution, and The Order of Washington. His parents, Amos Prichard Holden and Mary J. (nee Goodman) Holden, were New England horn and bred, but became residents of Cincinnati soon after their marriage, living there the rest of their lives. His father became a prominent merchant, and conducted the largest export trade to China of American ginseng in the entire country, beside doing an extensive mercantile business throughout the Ohio and Mississippi Valleys.

His mother's relatives (the Goodmans) also settled in Cincinnati and actively engaged in law, banking and insurance, and were the principal organizers of the famous Ohio Trust Company, the greatest financial institution west of the Alleghenies up to the time of the disastrous panic of 1857 . His paternal ancestors were Danish, Norman and Saxon, the family name first appearing as Hold (Danish, fort, or stronghold), then as Houldene (Norman-French) and finally as Holden (Saxon). A branch of the family came to America from Lincolnshire. England, toward the middle of the seven- 
teenth century, settling at or near the present town of Concord (Massachusetts); afterward removing to New Ipswich, N. H., where his father was born.

His maternal ancestors were Saxon, the name originally "Crudemanne" becoming finally Goodman. They came from Lincolnshire or Hertfordshire, England, and settled in Hartford during the seventeenth century (the exact date not determiner, although one James Goodman was a signer of the Mayflower "compact" and a passenger on that ship). In the same line was Captain Joseph Wadsworth, who hid the precious English charter in the oak tree, afterward known as the "Charter ()ak" of Hartford.

From Richard Goodman, a civic official and land owner of Hartford, he derives membership in the Order of Washington, and from his lineal descendant, Captain Moses Goodman, Sr. (West Hartford), membership in the Society of the Sons of the American Revolution. His son, Moses Goodman, Jr., was a colonel of infantry in the War of I8I2.

Mr. Holden's wife, Mary Catherine (nee McCarthy) Holden, is the daughter of the late Florence McCarthy and Elizabeth L. (nee Ashton) McCarthy, of Washington, D. C. The McCarthys, a noted family in Ireland, included in their number a long line of clergymen, writers, and teachers; among these the famous author, historian, journalist, and Member of Parliament, the Honorable Justin McCarthy. The world-famed "Blarney Castle" was built by the Clan McCarthy, and occupied by them until deprived of all their estates, during Cromwell's time.

His wife's maternal ancestors were English and amongst the early settlers in Plymouth Colony, and in the Revolutionary War won distinction for patriotic services. Her grandmother, I.11cinda Rebecca Lemon, was married to Robert Ashton, grandson of Sir George Ashton, the absolute owner of the town of Ashton, England.

Of Mr. Holden's father's family of four sons and four daughters, two members only, beside himself, survive, his elder brother now residing in Tryon, N. C., and his sister, Mrs. Nary Fowler Near, in Erie, Pennsylvania. 


\section{HOLCOMBE.}

Amasa Maynard Holcombe, Patent Lawyer, jio Pine St., St. Louis, Mo. Born October 27, I882, at Winchester, Massachusetts; educated in the public schools of Winchester, Massachusetts: Massachusetts Institute of Technology, Boston; and George IVashington Lniversity Law School, Washington. D. C. Member of tine Bar of the District of Columbia, and of the State of Missouri. Member of the Technology Club. New York City: University Club, Washington, D. C.; and Washington Patent Bar Association.

Great grandson of Amasa Holcomb, of Southwick, Massachusetts, farmer, astronomer, civil engineer and manufacturer of surveying and astronomical instruments. Said Amasa Holcomb was the first to take daguerreotypes of persons in the United States, and was honored by the Franklin Institute, Philadelpinia, for his success in making large telescopes of the reflecting type. (See Tols. It, I6 and I8, Journal of the Franklin Institute.)

Descendant of Thomas Holcomb(e), who settled at Dorchester. Massachusetts, in 1629, and removed to Windsor, Connecticut, in 1635 . Said Thomas Holcomb was a member of the Convention which framed the Charter of the Colony of Connecticut in I639, and he and his son Nathaniell, and grandson. Nathaniell (called Lieutenant Nathaniell), represented IVindsor in the General Court of Connecticut. Lieutenant Nathaniell and his son, Nathaniell (called Captain Nathaniell), were commissioned officers of the Colony of Connecticut in the French and Indian Wars, and owned lands in Simsbury, Connecticut.

Descendant of Silas Holcomb (grandson of Lieutenant Nathaniell and grandfather of Amasa), who was a lieutenant of Connecticut Militia in the Revolution, and a large landowner of Granbr, Connecticut. 


\section{HOLSTEIN.}

Otto Holstein was born in Lexington, Fayette County, Ke11tucky, on January I4, I883.*

In 1899 removed from Kentucky to San Antonio, Texas, where he followed railway transportation work, remaining in Texas for two years.

Removed to Arizona in I90I, following transportation work and remaining for three years, leaving to accept an appointment in the Philippine Islands where he served as a Lieutenant in the Telegraph Division of the Philippines Constabulary, being assigned first to Nueva Ecija Province in Northern Luzon, then to duty in the City of Manila and finally to duty in the Visayas, where he had charge of the telegraph district of the lslands of Leyte and Samar and the Province of Surigao in the Island of Mindanao. He remained in the Philippine Islands just three years.

I ater he accepted a commission to carry out some confidential work in China and Japan, which occupied about a year, upon the completion of which he returned to the United States, making his home, temporarily, in New York City.

He was with the Panama Railroad for a few months, when he received a cable offer of a position in Peru and went to Peru in May, I908, accepting a position with the Cerro de Pasco Railway Company, with office in Cerro de Pasco, Peru. After a year in Cerro de Pasco he was offered and accepted a position with the Central Railway of Peru, holding positions as Chief Dispatcher. Trainmaster and General Superintendent successively, remaining with this company for over four years, and having his offices in Lima, Peru.

In July. I913, he accepted a position as Superintendent of Transportation with the Guyaquil \& Quito Railway, with headqun rtors in Cuavenuil, Ecuador, South America.

From February, I9I4, to the present time, Superintendent of the Artesian Belt Railway at San Antonio, Texas.

Note: He has filed application for admission to the New Hampshire Society of the Cincinnati. He is informed that my papers have been found in order and correct and the matter comes for vote at the July 4, 1914 meeting of the Society at Exeter, N. H. 
Narried in Lima. Peru, South America, on August 20. IgII, to Esther San Martin. Children: Otto Holstein, Ir., horn Lima. Peru. South America, on August 3I, I9I2. Esther San Martin Holstein, korn Huigra. Chimborazo Pru rince, Ecuador. South America. September II, I9I3, and died in San Antonio. Texas, May I r, I9I4.

Pescended in the maternal line from the New Hampshire Gilmans, his mother's name haring been Emilie Octavia Gilman.

Descended in the paternal line from the noble family of ron Holstein, of Germany, his paternal grandfather having been Alexander ron Holstein and his paternal grandmother Julia Ann Pryor (only daughter of Major John Pryor, a Virginia Artillery Officer in the War of the Revolution.

His father was a Captain in the IIth Missouri Cavalry during the Ciril War and he also had ancestors who took part in all of the ITars in which the Colonies, and later the United States, engaged in.

The subiect of this sketch is the son of Otto Holstein, Sr.. who was a Captain in Troop D. IIth Missouri Caralry, during the Civil NTar of I86I-5. Son of Alexander (ron) Holstein, descended from the ancient Counts ron Holstein of the Lake Constance region of Germany. He married Julia Ann Pryor. cnly child of Major John Pryor, of Tirginia, and Mary Whiting. Major Pryor was on General Alexander's staff during the Rerolution and was previously a Captain in the First Continental Artillery.

His maternal line is: Emilie O. Gilman, daughter of Oscar Fitzerald Gilman and Belinda Fox. born in West Lebanon, X. H., in I853. Among her ancestors are Nathaniel Gilman, Rerolutionary and War of IEI2 Officer, Major Nicholas Gilman, an officer on General Washington's staff and one of the signers of the Constitution of the United States. His brother, Tohn Tarlor Gilman, was the first Governor of New Hampshire, an office to which he was re-elected a number of times. This same family also has members who held positions of honor and trust in Colonial days and their adrent in America dates from I63t. when Edward Gilman emigrated from Eng- 
land to Hingham (now in Massachusetts). Belinda Fox, his maternal grandmother, was the daughter of Benjamin Fox, a Revolutionary soldier.

He is a Fellow of the Royal Geographical Society (London): Fellow of the American Creographical Society (New York): Member of the National Geographic Society (Washington): Life Nember Navy League of the United States; Life Niember National Rifle Association of America; Life Nember Kentucky State Historical Society; Member of the Order of St. George of the Empire; Member Society Colonial Wars (New York) : Companion, Vice Commander for Texas of Order of Washington; Nember Sons of the Revolution (of N. Y.). Member, Sons of the American Revolution (District of Columbia); Member, Military Society of the war of I8I2-Veteran Corps of Artillery ; Member, Aztec Club of I847; Companion of the First Class (hereditary) Military Order of the Loyal Legion of the United States (District of Columbia); Member, Society of American Wars (New York); Member, Army of the Philippines; Nember, Washington Artillery (New Orleans).

Qualified and registered with the Alumnal Noblesse of the College of Arms of Canada with the arms of the Gilman family quartered with the von Holstein's of Germany. Arms as follows: Quarterly $\mathrm{I} \& 4$; Argent, a sun of 8 rays gules charged with an escutcheon parti-per fesse argent and azure for von Holstein: \& 2 \& 3, argent, a man's leg couped sable. for Gilman. Crest; a demi-lion issuing from a cap of maintenance. Motto: "Si Deus quis contra."

\section{HOWKINS.}

John W. Howkins was born in Savannah, Georgia, and is the son of Dr. J. S. Howkins and Elise Heyward, daughter of I. Cuerard Heyward and Pauline de Caradeuc. J. Guerard 
Heyward is the son of George Cuthbert Heyward and Elizabeth Martha Guerard, daughter of Dr. Jacob DeVeaux Guerard and Alice Screven, son of Joseph Guerard and Elizabeth, daughter of Jacob De Veaux and Elizabeth Barnwell, daughter of John Barnwell, son of Col. John Barnwell and Ann Berners.

George Cithbert Heyward was the son of Thomas Heyward anrl Ann Cuthbert, daughter of General Daniel A. Cuthbert and Mary Dupre Heyward, son of Dr. James Cuthbert and Mary Hazzard, and Thomas Heyward was the son of Thomas Heyward, Jr., one of the signers of the Declaration of Independence from South Carolina, by Elizabeth, daughter of Thomas Savage and Mary Elliott, and Thomas Heyward, Jr., was the son of Daniel Heyward, son of Captain Thomas Hey. ward, of Provincial troops. Above ancestors arrived in South Carolina in 1670.

\section{HUNGERFORD.}

Philip Contee Hungerford was born at "Tivoli Place," near Montrose, Westmoreland County, Virginia, on December 25, I863, and is the son of Major Philip Contee Hungerford and Amelia J. Spence, and grandson of Major Henry Hungerford and Amelia Spence, and great grandson of Lieutenant Thomas Hungerford III and Anne Washington, and great, great grandson of Thomas Hungerford II and Anne Pratt; great, great great grandson of Barton Hungerford and Elizabeth Gwinn and great, great, great, great grandson of Wm. Hungerford II and Margaret Barton, whose ancestor was Wm. Hungerford, who married Miss Smoote.

Lieutenant Thomas Hungerford was lieutenant of Company C. 3rd Virginia Regiment. Continental line, commanded by Lieutenant Colonel William Heth. He was wounded at Mor- 
ris Heights, ten miles from New York. Commissioned July I5, I777, 2nd Lieutenant 3rd Tirginia Regiment and served until September I4, I778. He died May, I803.

He was lineally descended from Wm. Hungerford, born in England, who went to St. Marys or Charles County, Maryland, I646-47. Soldier I647; one of a Special Jury October 3, I648; Member of Provincial Grand Jury December 5, I648; one of signers of Pro-Declaration 1650 ; received a land warrant for land to be laid out on Wicomico River. Thomas Hungerford II, born Charles County, Maryland, was High Sheriff of Charles County, Maryland, from October 8, I746, to October 22, I748. He removed to Virginia prior to 1764 and dird in King George, now Westmoreland, April 2, I772.

\section{HUNTER.}

The founder of this family in the United States was James Hunter, the great, great grandfather of the subject of this sketch, and was born in Londonderry, Ireland, in I764. He came to America from the Island of St. Christophers in $I 783$ and settled in Norfolk, Virginia, and married Miss J. Rodgers on February 28, I783. He died March 8, I821.

His son, William Frayze, great grandfather of Robert Williamson, was born February I5, I787. On July IO, I8Io, he married Henrietta Louise Andre, and he died November I5, I787. The son of William Frayze, William Henry, was born November 15, I814, and died Narch 4, I882. At the time of his death was clerk of the Courts of the City of Norfolk, Virginia. On May 25, I837, he married Eliza Frances Wallace. James Francis, son of William Henry, and father of Robert Williamson, was born November I, 1844; died Decemebr 25, I899, and was buried at Norfolk, Virginia. On November 2, I876, he married Anne McClennahan Tunstall, the daughter of Doctor Robert Baylor Tunstall, born August 3I, I8I8; dieil 
April 2. I883; married Elizabeth Walke Williamson. It was on his mother's side that Robert Williamson can trace direct lineage to Colonel George Brooke, who was a member of the House of Burgesses from 1768 to 1776 and member of the Virginia Convention of $1775-1776$. He was a Colonel in the Army of the Revolution and was also Treasurer of the State of Tirginia, I $78 \mathrm{I}-\mathrm{I} / 82$.

Robert Williamson Hunter was born August I4, I882, in the City of Norfolk, Virginia. He attended schools at the Norfolk Acadeny, Norfolk, Virginia, and the Jacob Tome Institute, Port Deposit, Maryland, graduating therefrom in 1900 and I9OI, respectively. The following year he entered Cornell University, Ithaca, New York, remaining there until June, I904. On July I, I904, he entered the Mechanical Department of the Southern Railway Company at Washington, D. C.., and has held ever since various positions with this Company or their allied lines. In March, I907, he became Chief Clerk to the Assistant Auditor of the Blue Ridge Railway Company with headquarters at Anderson, South Carolina. In November, 1908, he became the Assistant Auditor of the Tallulah Falls Railway Company with headquarters at Cornelia, Hahersham County, Georgia. Since May, I9ro, he has been an accountant in the office of the Assistant Comptroller of the Southern Railway Company, with headquarters at Washington, D. C. He is a member of the Order of Washington and Cornelia Lodge No. 92, F. A. A. M. For the past five years he has been Business Manager of the monthly paper published by the Parish of St. Thomas, at Washington, D. C., where he still resides.

Robert Williamson Hunter is the son of James Francis Hunter and Anne McClenahan Tunstall and grandson of Dr. Robert B. Tunstall and Elizabeth Walke Williamson. Dr. Robert B. Tunstall was the son of Alexander Tunstall and Elizabeth Todd Baylor, son of Richard Tunstall, Jr., and Catharine Prooke, daughter of Colonel George Brooke and Anne Tunstall. Colonel George Brooke was the son of Humphrey Brooke, Sr., and Elizabeth Braxton. Colonel George Prooke was a Colonel in the Tirginia State line three years, 
his heirs being allowed land bounty of 6666 2-3 acres for his services. He was also Member of House of Burgesses I768I776. In Virginia Conventions I775-76; Member of Council of Safety, King and Queen County, I775; Treasurer of Virginia $178 \mathrm{I}-\mathrm{I} 782$.

The father of Colonel George Brooke was Humphrey Brooke, Sr., the son of Robert Brooke, Sr., who was Justice of the Peace I692, Judge County Court of Essex County, Va., until s $\%$ os.

\section{HUNTER OF GEORGIA.}

Lieutenant Tracy Gould Hunter, Jr., of the Marine Corps, U. S. A., is the son of Tracy G. Hunter, of Savannah, Ga., and Sarah Margaret Smith Allen, daughter of George Allen, and Alice Guerard, daughter of Dr. J. De Veaux Guerard and Alice Screven, dlaughter of Dr. Richard Bedon Screven and Alice Pendarvis, whose name was changed to Bedon; daughter of Josiah Bedon and Elizabeth Stobo, daughter of Richard Park Stoho, son of James Stoho. son of Rev. Archibald Stobo and Elizabeth Park; Dr. Jacob De Veanx Guerard was the son of Josepin Guerard and Elizabeth Martha, daughter of Jacob De Veaux and Elizabeth, daughter of John Barnwell, son of Colonel John Barnwell and Ann Berners, and Joseph Guerard was the son of John Guerard and Mariana Godin.

Tracy C. Hunt r. Sr., was the son of William Hunter and Virginia Gould, daughter of Judge Gould, of Augusta, Georgia, who had married a lady whose maiden name was Cardner, of a prominent family of Augusta, Georgia, and the father of Judge Gould had a famous Law School in Litchfield, Connecticut, where young men from the South were educated.

William Hunter was the son of Wm. P. Hunter and Miss 
Sturgess, son of William Hunter, who married Margaret Glen, daughter of Chief Justice John Glen, I776-78, and Sarah, daughter of that sterling patriot, Dr. Noble Wymberly Jones, who, besiles holding many important positions, was a Delegate to the Continental Congress. He married Sarah, daughter of John Davis, Esq., a land owner and one who held official position.

Dr. N. W. Jones was the son of Honorable Noble Jones, who, as a friend of Oglethorpe, accompanied that illustrious general to Georgia in I732-3. Honorable Noble Jones held many official positions, both civic and military, being a Colonel, Iustice, Assistant to President of Colony, Treasurer of Province and Nember of the King's Council in Georgia.

William Hunter, who married Margaret Glen, was the son of Colonel John Hunter, of the British Army, and the crest of Hunter shows descent from the ancient family of Hunter of Hunterston. John Glen was the son of William Glen, who also held many official positions in South Carolina and who married Ann Alricks, granddlaughter of Hon. Peter A1ricks, of Delaware, who held many important positions and who married Maria Wessells, of New York.

\section{JOHNSTON.}

James Marion Johnston, born at Washington, D. C., February 27th, I850; granduated at Princeton in 1870 with degree of A. B., received degree of A. M. from Princeton in 1873 ; graduated in Law at Columbia (now George Washington) University in 1872 , traveled in Europe for a year and then returned to Washington and was in active law practice there 
until I888. In Narch of that year retired from practice to become a member of the firm of Riggs and Co., bankers. of that city, and, on the merger of that firm in the Riggs National Bark, became Vice President of the latter and so continued until his retirement from business in 1902. Besides these occupations served, also, as Director of the Riggs National Bank, Vice President and Director of the National Safe Peposit, Savings and Trust Company, Director and President of the Arlington Fire Insurance Company, Trustee and President of the Childrens' Hospital, Trustee of the Saint John's Orphanage, Treasurer and Trustee of the Louise Home. Director of the Real Estate Title Insurance Company and the Columbia Title Insurance Company, President of the Princeton Alumni Association of the District of Columbia, etc.

On November I8th, I886, James M. Johnston married Miss Sophy Carr, daughter of Captain Overton Carr, of the United States Navy, and Miss Sophia Bache Wilkins (married February 22nd, I848), and has three children, namely: James Marion Johnston, Jr. (born, I889; Princeton, A. B. I9II, Phi Beta Kappa); Sophy Stanton Johnston (born, I89I): and Eleanor Dallas Johnston (born, I889).

Captain Overton Carr was of the Virginia family of that name which had resided in Virginia since I7 Io and had held many important positions there. They were closely allied by marriage with the Dabneys of Virginia and the Bakers, Hansons and Addisons of Maryland. Captain Carr was the great nephew of Dabney Carr, who was so distinguishe? during Colonial days.

Sophia Bache Wilkins, wife of Captain Overton Carr, was the daughter of the Hon. William Wilkins, of Pennsylvania. who was a Judge, Member of Congress, and United States Senator, and was Minister to Russia, Secretary of War in President Tyler's Cabinet, etc. His father was Captain John Wilkins of the Revolutionary Army. Judge Wilkins' wife was Matilda Dallas, the daughter of Alexander James Dallas, lawyer, the first Reporter of the decisions of the Supreme Court of the United States (I Dallas Reports), first Secretary 
of the Commonwealth of Pennsylvania, Secretary of War and Secretary of the Treasury in President Madison's Cabinet, etc. Creorge Mifflin Dallas, the brother of Matilda Dallas, was Attorney-Geheral of Pennsylvania, United States Sienator, Vice President of the United States in the administration of Mr. Polk, Minister to Russia and Minister to England, etc. James M. Johnston is a descendant of Dr. Andrew Johnston, who came to this country and settled in Savannah about I750. The latter's father was Surgeon James Johnston (born I686) of the British Navy, who married Jean Nisbet at Dumfries, Scotland, on February I6th, I722, and who belonged to a cadet branch of the Scottish house of Johnston, Earls and Marquises of Annandale. Several of the children of James Johnston came over to America together. Of these the eldest, Dr. Lewis Johnston, practiced medicine in Savannah, in partnership with Dr. John Irvine, and was a member of His Majesty's Council and also Chief Justice and Treasurer. His descendants (the Almons, Ritchies and Johnstons) now live in Halifax, Nova Scotia. One of them, Hon. James William Johnston, was Speaker of the Provincial Assembly, and his portrait still hangs in the Assembly hall. Another, Richie, became Chief Justice. Dr. Andrew Johnston (I735-I80I), the next younger brother of Dr. Lewis Johnston, also practiced in Savannah, except during the Revolutionary War, in which he took no part, as all of the family were royalist in sentiment. Both of these brothers were men of high education, graduates of Edinburgh University, and both stood well in their profession. Dr. Andrew Johnston's notebook, now in the possession of Mr. James M. Johnston, is written wholly in Latin and shows the writer to have been a man of wide reading, both in Medicine and in general literature. On December 24. 176r, Dr. Andrew Johnston married at Savannah Miss Bellamy Roche (died, I780) of South Carolina, and had nine children.

Colonel James Johnston (I769-1822), the fifth child of this marriage, was a highly intelligent and prosperous banker and left a large estate to his family on his death. He published 
the first newspaper in the State of Georgia. He is buried with his wife at Bonaventure Cemetery in Savannah. On May 3Ist, I792, he married, at White Bluff, near Savannah. Ann Marion Houstoun (died, I8I7), the daughter of Sir George Houston, the seventh baronet of that name, and his wife, Ann Moodie. The latter was the daughter of Thomas Moodie, a son of the Lairds of Cocklaw, of Fifeshire, Scotland. When about twenty-one years old he ran away from home, married a beautiful Miss McKenzie, of a "Lowland" family from near Eidinburgh, and came over to the Province of Georgia. In a proclamation signed in I774 by Sir James Wright, the last Royal Governor of Georgia, Thomas Moodie was appointed Deputy Secretary.

The first representative in America of the Houstoun family of Scotland, was Sir Patrick Houstoun, fifth Baronet, who married Priscilla Dunbar. He settled at Frederica. St. Simons Island, in the Province of Georgia, in I735, and soon became prominent in the Colony. In I75I he was a delegate to the first Provincial Assembly, and was appointed Register of Grants and Receiver of Quit-Rents in I754. In I757, when Lord Chatham issued a call for men and money for an offensive movement against the French in Canada, the reply thereto was written and signed by Sir Patrick, by order of the Upper House. Later, this Sir Patrick became President of His Majesty's Council in Georgia. He died in I762, aged 64 years. Lady Houstoun, his widow, died in 1775 . He left five sons, namely:

I. Sir Patrick, sixth Baronet, who was appointed to a seat in His Majesty's Council just the Royal authority came to an end, and who held several other offices. Being himself a staunch loyalist he became disgusted with the growing spirit of rebellion and returned to England, where he died at Bath in 1785 .

2. Sir George, seventh Baronet, was mentioned above as the father of Ann Marion Houston, wife of Colonel James Johnston. Sir George was a man of great prominence in the Colony. As Masonic Grand Master of the State of Georgia, 
and in company with General Anthony Wayne, President of the Society of the Cincinnati, he presented General George Washington with an address on the occasion of Washington's visit to Savannah in May, I 789 .

3. John Houstoun, third son of the fifth Baronet, was elected Governor of Georgia in 1778 , was twice a member of the Continental Congress, and was the first Mayor of Savannah.

4. James, the fourth son, was a surgeon in the Continental Army.

5. William, the fifth son, was also a man of influence. He was a delegate to the Convention in New York to frame the Constitution of the United States, and while there he married Miss Bayard, the daughter of Nicholas Bayard of "Bayard Hill." Houston Street, New York; City, which was cut through the "Bayard Hill" estate, was named after him.

Colonel James Johnston and his wife, Ann Marion Houstoun, had a son, William Patrick Johnston, who was the father of James M. Johnston. William P. Johnston was born in Savannah on June IIth, I8I2. After graduating at the "Round Hill School," conducted by Dr. Coggswell and George Bancroft, the historian, and taking his degree at Yale College in 1833 , he received the degree of M. D. from University of Pennsylvania in 1836 . He then served as a physician at Blockley Hospital in Philadelphia for a year, after which he traveled and studied in Europe until I840. He then began the practice of his profession in Washington, and so continued without interruption until his death on October 24th, 1876. During his professional life Dr. Johnston was much respected for his abilities and beloved for his genial and magnetic temperament. He received numerous professional honors in the medical societies of Europe and America, and otherwise, and he gave freely of his time and professional abilities to hospitals and other similar charities. In 1840 Dr. Johnston married Mary Elizabeth Hooe, the daughter of Bernard Hooe, Esq.. of Virginia, and his wife Eleanor Buchanan Briscoe, of Marylan.

Bernard Hooe was descended from Rice Hooe, who was born in England in I599 and settled in the colony of Virginia 
about I620. He was Burgess from Shirley Hundred Island, and was Burgess, Magistrate, and member of the Colonial Assembly for Charles City County. He married in England, a Miss Jane Seymour. Bernard Hooe, the father of Mary Elizabeth Hooe, was the sixth generation in lineal descent from the original Rice Hooe. The intervening Hooes had married members of the following families: Taliaferro, Howson, Bernard, Fowke, etc. Mary Symes Chichester, the mother of the Bernard Hooe above mentioned, was the daughter of Richard Chichester, of Fairfax County, and his wife, Sarah McCarty. Richard Chichester was descended from the Chichesters and Balls of Lancaster County. Colonel William Bail, the first of the name who came to this country, was the most prominent military officer in Virginia from about I650 to I680. He was a great grandfather of General Washington. The Sarain McCarty above mentioned was the daughter of Colonel Daniel McCarty, son of Captain Daniel McCarty, of Westmoreland County. Both of the latter held many prominent military and civil offices.

Eleanor Buchanan Briscoe, who married Bernard Hooe, and was the mother of Mary Elizabeth Hooe, wife of Dr. William P. Johnston, was the daughter of Dr. John Hanson Briscoe, of Maryland. The latter had received a fine classical and medical education at Edinburgh, and served with distinction, both as an officer and a surgeon in the Revolutionary Army. His mother was Chole Hanson, of the Maryland family of that name, which was also prominent in the army and in civil life. Her grandfather, Colonel John Hanson, came to this country in I642. He was the son of a Swedish officer, who acted as the personal aide of Gustavus Adolphus. throughout his campaigns, and who was killed at the battle of Irutzen in 1632 , defending the fallen body of the King.

As already stated, Dr. William P. Johnston married Mary Elizabeth Hooe. Their children, who lived to reach maturity, were one daughter, Mary Bellamy Johnston, who is now living; Dr. William Waring Johnston, born in 1843 and died in I902, who was himself a very distinguished physician; Bernard 
Houstoun Tohnston, born in 1845 and died in I905: Tames M. Tohnston, and Dr. George Toodruff Tohnston (born in I858), who is also a highly cultivated physician, and is still living.

\section{NOBLE JONES.}

G. Noble Tones was born in Savannah, Georgia, on November 6th, I8/4. Was educated at Lniversity of Tirginia and University of Georgia, receiving the degree of Bachelor of Laws at the latter institution in June, I895. since which time he has practiced his profession in Saramnah.

Mr. Tones has been interested in matters relating to lands and to questions concerning taxation, and has acquired large ownership of land and is chairman of the board of tax assessors of the City of Savannah. He holds a commission as lieutenantcolonel and aide-de-camp on the stafi of the Governor of Georgia. is at the head of the Society of Colonial Wars in the State of Georgia, and holds memberships in the Society of the Cincinnati, the Sons of the Rerolution and is Tice Commander General of the Order of Tiashington.

In I904 Mr. Tones was married to Frances Meldrim, and there are five children of this union: Frances Meldrim. Anna Habersham, Noble Timberley. Caroline Wallace and Ralph Meldrim.

Frances Meldrim is the daughter of General Peter $\mathrm{T}^{\mathrm{T}}$. Meldrim. President of the American Bar Association, who married Miss Caser, a descendant of the Casey and Berrien families of Georria.

Colonel G. Noble Jones comes of a long line of distinguisined ancestry. embracing many illustrious ancestors distinguished in Colonial and Revolutionary periods, among whom may be mentioned Honorable Colonel Toble Tones. of His Majesty's Council. Dr. Noble Wymberley Tones, the sterling patriot of I $\%$. and the families of Campbell. Gibbons. Fenwich. Gibbes. Buil. Drayton and Davis and others on the paternal side. and on the naternal side the distinguished family of Habersham and the ancient families of Camber. Rae, Bolton. Curtis. Bowers. Tunster. Adams and many others. 
Colonel G. Noble Jones is the son of George Fenwick Jones and Anna Wylly Habersham, son of George Noble Jones and Mrs. Mary Nutall, daughter of Thomas Savage and Mary Anderson Wallace, daughter of Hon. John Wallace and Mary Anderson, daughter of George Anderson and Deborah Grant. Thomas Savage was the son of Thomas Savage, of South Carolina, and Mary, daughter of Hon. William Butler and Mary Elliott, of South Carolina. George Noble Jones was the son of Noble IVimberley Jones, attorney-at-law, who married Sarah Campbell, daughter of the Revolutionary patriot, MacCartan Campbell, who married Sarah Fenwick, daughter of Hon. Edward Fenwick, born January 2, 1726, died July 8, 1775, who was, in I747, member of His Majesty's Council, who married, second, Mary, daughter of Thomas Drayton and Elizabeth Bull, daughter of Wm. Bull, Lieutenant-Governor of South Carolina. Hon. Edward Fenwick was the son of Hon. John Fenwick, Judge and member of His Majesty's Council in 1730, who married Elizabeth, daughter of Gov. Robert Cribbes, of South Carolina. Hon. John Fenwick was the son of Robert Fenwick and Ann Culchetch, son of Edward Fenwick of Staunton, and Sarah Neville, son of Wm. Fenwick of Staunton. Noble Wimberley Jones was the son of Honorable George Jones, M. D., U. S. Senator, who married first Mary Gibbons, daughter of that prominent patriot, Hon. William Gibbons, and Dr. George Jones was the son of Dr. Noble Wimberley Jones, styled the Morning Star of Liberty, who married Sarah Davis, daughter of John Davis, Essq., planter, and who also held official position in Colonial days, and Dr. Noble Wimberley Jones was the son of Hon. Noble Jones, member of His Majesty's Council, who married Mary Wimberley (see note in Bulloch Genealogy), and who. went to Georgia with Oglethorpe.

Having given the paternal line of Colonel Noble Jones, we shall now show his distinguished ancestry on his maternal side.

Anna Wylly Habersham, who married G. Fenwick Jones, was the granddaughter of Dr. Joseph Clay Habersham, who married Ann Wylly Adams, daughter of Nathaniel Alexander 
Adams, born 1797, who married Mary Ann Wylly, daughter of Colonel Richard Wylly and Nary Bryan, daughter of Joseph Bryan, who married, in I74I, Mary Story, son of Joseph Rryan, of South Carolina, and Janet Cochrane. The last Nathaniel Arlams was the son of Nathaniel Adams and Ann Bolton, daughter of Robert Bolton, of Savannah, who married Susannah, daughter of Nathew and Jane Mauve, and Robert Bolton was the son of Robert Bolton, of Philadelphia, Pa.; Church Warden of Christ Church and Ann Clay, widow, daughter of Winlock Curtis and Ann Bowers, daughter of Benanuel Bowers, of Massachusetss, and Elizabeth, cousin of Henry Dunster, first President of Harvard College. Winlock Curtis was the son of Hon. John Curtis, member of Penn's Council, Kent, on Delaware. Nathaniel Adams, planter in Georgia, who married Ann Bolton, was the son of Nathaniel Adams and Margaret, daughter of Edmund Ellis, son of David Adams and Elizabeth Capers, daughter of Richard Capers, planter, of St. Helena, S. C. David Adams was born in Massachusetts and was the son of Nathaniel Adams and Hannah, daughter of Nicholas Wilmot.

Anna Wylly Habersham, who married G. Fenwick Jones, was the daughter of $\mathrm{Wm}$. Neyle Habersham and Josephine Habersham, daughter of Dr. Joseph Clay Habersham, Sr., and Ann Wylly Adams, and Dr. Habersham was the son of Major John Habersham and Ann Sarah, daughter of Thomas Camber, Esq., son of Hon. James Habersham, Acting Governor of Georgia and President of His Majesty's Council, who married Mary Bolton, sister of Robert Bolton, whose daughter, Anne, married Nathaniel Adams, Esq., planter, of White Bluff, Georgia.

IVm. Neyle Habersham was the son of Robert Habersham and Elizabeth Neyle, daughter of Wm. Neyle, son of Gilbert Nevle, and Robert Habersham was the son of Colonel Joseph Habersham, of the Georgia Society of the Cincinnati, a sterling patriot of 1776 and subsequently Postmaster General of the United States, who married Isabella Rae, of the ancient family of Rae of Georgia. Colonel Joseph Habersham was the son of Governor James Habersham and Mary, daughter 
of Robert Bolton, of Philadelphia, Pa., Church Warden of Christ Church, who married Ann Curtis, daughter of Winlock Curtis, son of Hon. John Curtis. We thus see that Colonel Noble Jones is descended from the two brothers, Lieutenant-Colonel Joseph and Major John Habersham, President of Exxecutive Council, sons of Governor James Habersham and Mary Bolton. From Robert Bolton, of Philadelphia, Pa., we find that branches of the following families descend: Bolton, all of the Habersham family and branches of the Kings of Georgia; Newell, Turner, McBryde, Lewis, Bulloch and Adams's, and others; and we also see that from the Fenwicks descend the families of Tattnall, Kollock, and of a branch of Adams and others.

Note.-Hon. James Habersham, Sr., is styled President and Commander in Chief of Province and Ordinary of the same, April 10, 1772 .

The following positions were occupied by James Habersham, Jr.: Rebel Financier, Magistrate, August, I78I ; Justice, Jannary, I782; Speaker of House of Georgia Assembly, July, I782; member of House, Commissioner for Regulation of Pilotage of Bar, Savannah River; Trustee State College; Collector Port of Savannah. (See Colonial Records of Georgia, etc.)

Major John Berrien, of New Jersey, was the youngest child of Justice John Berrien, of New Jersey, who married Margaret Eatton, August I6, I759, of Trenton, N. J.

Major John Berrien married, first Margaret McPherson, of Philadelphia, and had: ( I) John McPherson Berrien. Major Berrien married, second, Wilhemina Moore and had:

I. Ruth Perrien, married Dr. James Whitehead.

2. Julia Berrien married Dr. Carlton Belt. She married, second, Judge John Whitehead.

3. F.liza Berrien married Samuel Dowse.

4. Wemyss Berrien married-

5. Sarah Berrien* married Dr. John A. Casey.

*Married in Louisville on 10th inst., by Rev. W. J. Brantley, Dr John A. Casey of Augusta, Ga., to Miss Sarah Eliza Berrien, daughter of Major Berrien. Thursday, Dec. 21, 1809.-Savannah Republican. 


\section{KING.}

Charles William King. Vice Deputy Commander of the Order of Washington, and member of the Howell Cotton Company, of Rome, Georgia, was born in Columbus, Georgia, on August 4. I853. His brother, James Nephew King, President of Howell Cotton Company, of Rome, Georgia, and a prominent citizen of Georgia, was born in Savannah, Georgia, on June 20, I859.

These brothers were sons of Rer. Charles Barrington King and Anna Wylly Habersham, daughter of Dr. Joseph Clay Habersham and Ann Wylly Adams, daughter of Nathaniel Adams and Mary Ann Wylly, daughter of the Revolutionary patriot, Colonel Richard Wylly and Mary Bryan, daughter of Joseph Bryan and Mary Storey, son of Joseph Bryan, brother of Hon. Jonathan Bryan, son of Joseph Bryan, of South Carolina, and Janet Cochrane. Nathaniel Adams was the son of Nathaniel Adams and Mary, daughter of Robert Bolton, of Savannah, and Susanna Mauve. (See Bolton Sketch.) Nathaniel Adams, the last mentioned, was the son of Nathanicl Adams and Margaret, daughter of Edmund Eliis, of St. Helena, S. C., who had a grant of a lot in Beaufort, S. C., July 25, I $7 \mathrm{I} 7$. and Nathaniel Adanns was the son of David Adams and Elizabeth Capers, daughter of lichard Capers, and Dirid Adams was the son of Nathaniel Adans, of Charlestown, Massachusetts, and Hannah, daughter of Nicholas Wilmot.

Dr. Joseph Clay Habersham was the son of Major John Habersham, of the Continental Army, who was also President of Executive Council of Georgia. He married Ann Sarah, daughter of Thomas Camber, Esq., whose other daughters married Adam Fowler Brisbane, and George Walton, the Signer of the Declaration of Independence. Major John Habersham was the son of Governor James Habersham, a distinguished citizen of Georgia, who married Mary, the daughter of Robert Bolton, of Philadelphia, Pa., and Ann, daughter of Winlock Curtis, son of Hon. John Curtis, of Kent, on Delaware, Pa. We thus see these companions of 
the Order of Washington descended from many illustrious ancestors.

Rev. Charles Barrington King was the son of Barrington King, Esq., President of Roswell Cotton Co., of Roswell, Cobb Co., Georgia, and his wife, Catharine Nephew, daughter of James Nephew, planter, and his wife, Mary M. Gignilliat, daughter of James Gignilliat and Caroline Pepper, daughter of Dr. Pepper and Sarah, daughter of Sir John Evelyn. James Gignilliat was the son of John Gignilliat and Mary Magdalen Du Pre, son of Abraham Gignilliat, son of Jean Francois de Gignilliat, who had a grant of 3000 acres of land from the Lords Proprietors, and his wife, Susanne Le Serrurier, son of Abraham Gignilliat, who arrived in America in 1685 , and his wife, Mary De Ville. James Nephew was the son of Peter Nephew, who had a grant of land of Ioo acres on Little Ogeechee River, having gone to Georgia before I754. He was one of the Commissioners of Roads in the Colony, between I768-I773, and married Mrs. John Cooper, widow of Col. John Cooper. Her name was Merriam.

Barrington King was the son of Roswell King, the founder of Roswell, Georgia, who married Katharine Barrington, daughter of Josiah Barrington, one of the Commissioners of Roads in the Colony of Georgia, I768. He married Miss Williams, of an old family, who were related to the celebrated General, James Edward Oglethorpe, founder of the Colony of Georgia.

Roswell King was born in Sharon, Conn., May 3, 1765 , and soon after the Revolutionary War, removed to Georgia. He was the son of Captain Timothy King, prominent on the Continental side in the naval service during the Revolutionary War. Captain Timothy King was the great grandson of Captain John King, who settled at Northampton, Mass., in $\mathbf{1 6 4 5}$, and was military commander for that settlement.

Harris Macleiod King, represents, on both paternal and 
maternal sides of the house, families that have long been prominent in naval, military, civic and historical affairs of Ceorgia. Harris Macleod King has himself been actively associated with the development and promotion of the commercial interests of the State in the naval stores business, being the Supervising Inspector of Naval Stores for the State of Georgia, his home being Sarannah. A son of Col. Barrington S. King. he was born in Roswell, a town whch was named in honor of his great grandfather, Roswell King.

Roswell King was born in Sharon, Connecticut, May 3. I765, being a son of Captain Timothy King, who was prominent on the Continental side in the naval service of the Revolutionary Mar, being commander of the Brig "Defiance," I.2 guns and 70 men. Captain Timothy King was the great grandson of Captain John King, who settled at Northampton, Mass., in $16+5$, and was military commander for that settlement in I692. Soon after the Revolutionary War, Roswell King migrated to Georgia, and settled at Darien. McIntosh County. He subsequently married Catherine, a daughter of Josiah Barrington, who was born in Ireland, and emigrated to Georgia a few years after the arrival in this State of Gen. Oglethorpe, who was his kinsman and friend. Old Fort Barrington, on the Altamaha, an outpost built for defense against the Spaniards, was named for him.

Their son, Barrington King, Mr. King's grandfather, was born in Darien, March 8th. I798. About I839, with a colony of several other families from the seacoast of Georgia, including the Bullochs, Lewises, Dunwodys, Pratts, Gouldings, and others, he migrated to Cobb County, and located on the site which his father, Roswell King, had some years before purchased from the Indians, and founded the little town of Roswell, which, as preriously stated, was named in honor of his father. His wife, whose maiden name was Catherine M. Nephew, was a daughter of James Nephew, who, during the Revolutionary War, served as lieutenant in Col. John Baker's regiment, of the Liberty County. Georgia, militia.

Barrington S. King was born while his mother was visiting the Bulloch family, at Sand Hill, Liberty County, the King 
home at that time having been at Darien. Throughout the entire period of the war between the States, Col. King served as a gallant soldier and officer in the Confederate Army, his activities being mostly in the Army of Northern Virginia. Promoted to the rank of lieutenant-colonel in Cobb's Georgia Legion, he made a distinguished record for daring and fearless bravery, and on March I0, I865, he was killed at the head of his command, in Kilpatrick's charge, in the battle of Averysboro, N. C.

The maiden name of the wife of Colonel King was Sarah Elizabeth Macleod. She is a lineal descendant of Francis Harris, who was among the first settlers in Savannah, and prominent in the Colonial service of Georgia, having been elected Speaker of the first Colonial Assembly, and also was a member of Council under Gov. John Reynolds. He was a prominent factor in the commercial development of Savannah, having in I744 associated himself with James Habersham, under the firm name of Harris \& Habersham, and established one of the first exporting houses of Savannah, which business was continued up to the time of his death. She is the daughter of the late William Harris Macleod, and a granddaughter of Francis Harris Macleod, whose father, Dr. Donald Macleod, of the distinguished Macleod family of Skye, Scotland, served as a surgeon in the British Army in the war against the colonists. After the war, however, Dr. Macleod became a loyal American citizen, and settled in Savannah, and married Elizabeth Harris, only daughter of Francis Harris, alluded to above.

Mr. King received his elementary education in the schools of Roswell and Marietta, finishing up at Kenmore University, Amherst County, Virginia. Since then, he has been actively engaged in the naval stores business, a part of which time he was at Brunswick, Ga., as manager for the Brunswick office of the Savannah concern of John R. Young Company. A.fter that office was discontinued, he was appointed as Supervising Inspector for the State, which position he now holds. Hd was married in 1884 to Miss Georgia H. Baker, of Marietta, Ga. 
Miss Baker was a native of South Carolina, and was a granddaughter of Milliam de Griffin Trenholm of Charleston.

Mr. and Mrs. King have four children, Harris M. King, Jr., Irene Trenholm King, Barrington King, and Pauline Trenholm. Mr. King is a member of the Order of Washington, the Sons of the Revolution, the Society of Colonial Wars, and the Society of the Cincinnati, and also a member of the St. Andrew's Society and Hibernian Society.

\section{LITTELLL.}

Colonel Isaac William Littell was born in Elizabeth, New Jersey, the son of Isaac IVilliam Littell and Elizabeth Cleveland Ball. He is the direct descendant, on his mother's side, of the Martha Ball Washington family, and of the Cleveland fanily, and so directly related to two of America's most illustrious Presidents. On his father's side he is the great, great grandson of Isaac William Littell, an officer of the Colonial Army, who fell in battle during the War of the Revolution; and a direct descendant of Sir Isaac IVilliam Littell oi England. As a boy, Colonel Littell attended the "Pingry Institute" of New Jersey, and graduating from this he went to Stevens Institute, taking the Mechanical Engineering course: and from there he went to the U. S. Military Academy at West Point, graduating from there, and receiving his commission in the Regular Army of the United States in I883. In 1885, he married Julia Barrett, daughter of Colonel and Mrs. Gregory Barrett, U. S. A., of Maryland and Virginia. Colonel Littell's early service was in Colorado and New Mexico and while there he was appointed regimental adjutant of the Tenth Infantry, in which capacity he served until his appointment in the Quartermaster Corps of the Army. This appointment took him to Texas, as assistant to the Chief Quartermaster of 
the Department. During the Cuban War, Colonel Littell, then a Captain, was assistant to Colonel Kimball at the New York Depot,-one of the most actively busy places in the country at that time. In I899. Captain Littell was ordered to the Philippines where he served with General MacArthur during his Northern Campaign. This finished, Captain Littell was made Chief Quartermaster of Southern Luzon, then assistant to the Chief Quartermaster of the Philippines, and finally Chief Quartermaster of Northern Luzon. After three years. Captain Littell returned to the New York Depot, where he remained but a short time, as he was called to the Quartermaster-General's office in Washington, by General Humphrey, as one of his assistants. He remained here five years, during which time he received his Lieutenant-Colonelcy, and then went to Governors Island, New York, as Chief Quartermaster of the Division of the East, serving under both General INoor and General Grant. From Governors Island, Colonel Littell was ordered back to the Philippines, this time as Chief Quartermaster of the Division of the Philippine Islands. Here he remained for three years, during which time the consolidation of the three large branches of the service, the Quartermaster. Commissary, and Pay Departments, into the Quartermaster Corps took place, and Colonel Littell was placed at its head.

Colonel Littell has now returned to $\mathrm{Washington}$ and is in the office of the Quartermaster-General of the Army. General Aleshire, as one of his assistants.

\section{LOOMIS.}

Archie Harwood Loomis.

Joseph Loomis, the pioneer, born probably before I 590, son of John and Agnes Loomis, came from Braintree. Co. Essex, Eng., where he was a woolendraper. He married June 3o, i6r4, at Messing, Co. Essex, Eng., Mary White, baptized August 24. I590, daughter of Robert and Bridget (Allgar) White. He sailed from London April I I, I638, in the "Susan 
and Eillen," and arrived at Boston July I7, I638, tarrying about I year at Dorchester, Nass., it is thought. That he was one of the early settlers of Windsor, Conn., is shown by the town records wherein it is mentioned that on Feb. 2, I640, he had 21 acres of land on the west side of the Connecticut river, granted him from the plantation, also several large tracts of land on the east side of the river, partly from the town and partly by purchase. He is supposed to have come with Rev. Ephraim Huet, who arrived at Windsor August 17, 1639. He brought with him his wife and their 8 children. The original home, still standing, has always remained in the possession of his descendants and the property is now the site of the Loomis Institute. Admitted to the clurch October I I, I640. In I642 and again in 1644 he served as a member of the Particular Court which was the highest strictly judicial body in the Connecticut Colony. His wife died August 23, I652, and he died November 25, 1658. He was of an excellent family and had the title of respect "Master," which was indicative of good social standing, prefixed to his name in the ancient records. His son Thomas Loomis, born England, I624, married November I, I653, Hannah, daughter of Henry Fox (Fowkes). He was a freeman in 1654 and admitted to the church April 3, I666. On Narch II, I657-8 his name appears as a member of a troop of horse, the first in the colony, which was organized by the General Court and placed under the command of Capt. John Nason. He was also a member of a company which served in King Philip's War in $1675-6$. His wif died April 25, 1662, and he died August 28, 1689. His son,

Thomas Loomis, born Windsor, March I7, I655-6; married Decemker I7, I682, Hannah, born January I, I662-3, daughter of John and Mary (Stanley) Porter. His wife died January I, I739-40 and he died April I9, I746. His son,

Sergeant Gershom Loomis, born Windsor, April 9, I70I, married June, I736, Mary, born Windsor, April I7, I702, daughter of Natthew and Hannah (Chapman) Grant. He died December 27-26, I738, and his wife died January 24, I780. His son, 
Deacon Amasa Loomis, born Windsor, February 19, I737-8: married February 6, I783, Mrs. Priscilla Birge, widow of Capt. Jonathan Birge and daughter of Elijah and Mary (Kingbury) Hammond of Bolton, Conn. She was born August 6, I74I, and died February 28, I8I5. In the Revolutionary War he, as Captain, commanded a company of militia and marched, I775, for the relief of Boston, with 43 men. He served at West Point in I78o. Member of the Connecticut Legislature I779. He died July I, I793. His son,

Chauncey Loomis, born East Windsor, March 23, I784; married Elizabeth, born August 24, I778, died December 28, I836, daughter of Daniel and Zerviah (Loomis) Hayden. He died January 9, I873. His son,

Pascal Loomis, born East Windsor, June I7, I804; married Hartford, Conn., March 9, I 825, Martha Jones, born Hartford, December 20, I805, died Hartford, January 28, I888, daughter of Archibald and Martha (Patty Jones) Greenfield and granddaughter of Archibald Greenfield, a sea captain, who came from Scotland and settled at Lyme, Conn. Served as special constable and fire warden; was a strong abolitionist and temperance man. Builder. Republican. A man of strong character and convictions and regarded with that esteem which is ever accorded to those whose conduct is exemplary and whose influence is salutary. He was an active member of his church (Congregational) which he joined in 1828 . Ho died Hartford, February 6, I885. His son,

Archibald Gilbert Loomis, born Hartford, June 20, I848; married Brooklyn, N. Y., November I I, I869, Mrs. Cordelia Gertrude (Harwood) Loomis, born New York City, August I6, I839, died Brooklyn, September I 5, I873, daughter of John Wesley and Margaret (Ryerse) Harwood, the latter a descendant of early Dutch settlers of Harlem. He entered the Aetna National Bank of Hartford, as messenger, in I865, and rose through every position to President and director. Became first Vice-President of the National City Bank of New York in April, I899. In December, 1905. moved to San Francisco, Cal., to represent large New York interests and in 
April, Ino6, was driven out by the terrible earthquake and fire. Mored to Providence, R. I., and became Vice-President and director of the Lnion Trust Company. He is a successful executive and a banker of large experience and rare judgment. One of the most expert judges of the value of commercial paper in the country and in this particular specialty, which calls for the most exacting knowledge, the keenest discrimination and a logical sifting of an enormous mass of detail, he is unsurpassed. Member of Hope Club. Providence! R. I., Hartford Club, Union League Club of New York and Bohemian Club of San Francisco. His son.

Archie Harwood Loomis, born Hartford, April 30, I87I; married New York, April 27. 1904. Grace Maud, born Titusville, Pa., November 9. I878, daughter of Dr. Josiah Edwin Henry (a naral pensioner of the Civil war) and Matilda (Jacacks) Gumning. Entered the Society for Savings, Hartford. I889. Moved to New York in I899 and became connected with The Farmers' Loan \& Trust Co., and represented that company at Paris, France, at one time. In I9I I President and director of the Birminghan Coal \& Iron Co. Member of the Republican County Committee of Essex County, N. J. Nember of the Order of the Founders and Patriots of Ameri$\mathrm{ca}$, Sons of the American Revolution, Order of Washington. Connecticut Historical Society, New York Genealogical and Biographical Society, etc. Residence, Upper Montclair, N. J. Three children-Archibald Gunning Loomis, born New York, March 28, 1905. Harwood Loomis, born New York, September 5, rgo6, Winthrop Greenfield Loomis, born Upper Montclair, December I7, I9I I.

\section{PATENT OF THE TOWN OF STRATFORD, CONN.}

Whereas the General court of Connecticut have formerly Granted to us, the proprietors, Inhabitants of Stratford all those lands both meadow \& upland with these abutments viz upon the sea on the Sea shore South on Stratford River on the east \& on Fayerfield Bownds on the west \& to run from the sea on the south the whole Bredth of twelve Miles \& from the Ioewest corner to run easterly of Stratford River \& abutts on 
the Wilderness on the North the said Land having been by purchase or otherwise bytoyned of the Indian Native proprietors \& whereas the proprietors the afoar Sayd Inhabitants of Stratford in the colony of Connecticut after making Aipplication to the Governor \& company of the Sayd Colony of connecticutt assembled in court May 25th 1685 that they may have a patent for confirmation of the afoar Sayd Lands so purchased \& Granted to them as afoar Sayd \& which they had Stood Seized \& quietly possessed of for many years late past without Interruption now for a more full confirmation of the afoar Sayd Tract of Land as it is Butted \& Bownded afoar Sayd unto the present proprietors of the Township of Stratford in their possession \& Injoyment of the premises Know yee that the sayd Governor \& Company assembled in General Court according to the commission \& By vertue of the power Granted to them by our Late Soveraigne Lord Charles the IId of blessed memory In his Letters pattents bearing date the three and \& Twentyeth years of his Sayd Maties Reigne have given $\&$ Granted \& by these presents doe give grant rattify \& confirme unto Capt Wm Curtice, Mr Joseph Hawley Mr Isaac Niccols Mr Jeremy Judson Let John Beardslie ensigne Steven Burrit Sergt John Curtice Mr Richard Blackleach Mr Timothy Wilcockson $\mathrm{Mr}$ John Wells Mr Samuel Sherman and Mr E.phraim Stiles \& all the rest of sayd present proprietors of the Township of Stratford \& their heirs \& assignes forever $\&$ to each of them in Such proportion as they have already agreed upon for the divission of the Same all that fore Sayd Tract \& parcels of Land as is it is butted \& Bownded together with all the woods uplands arrable lands meadowes pastures havens portes waters Rivers with all adjoyneing Islands fishings therein Huntings fowleings mines, Mineralls, Gurries \& precious Stones upon or with the Sayd Tract of lands with all other proffits \& comodities there unto belonging or in any wise appertaineing \& doe allso Grant unto the afoarnamed Capt W'm Curtice Mr Joseph Hawley Mr Isack Niccols Mr Jeremy Judson Let John Beardsly Ensign Steven Burret Sergt John Curtice Mr Richard Blackleach Mr Timothy Wilcockson 
Mr John Wells Mr Saml Sherman \& Mr Ephriam Stiles \& the rest of the present proprietors Inhabitants of Stratford afoarsayd their heirs \& assigns forever that the abovesayd tract of land shall be forever deemed reputed \& be an Intire Township of it selfe to have and to hold the Sayd Tracts of land premises with all $\&$ every there appurtenance together with the priviledges Immunities \& Franchises herein given \& granted unto the said Capt W'm Curtice Mr Joseph Hawley Mr Isaac Niccols Mr Jeremy Judson Leut John Beardsly Ensign Steven Burret Sargt John Curtice Mrr Richard Blackleach Mr Timothy Wilcockson Mr John Wells Mr Samuel Sherman \& Mr Ephraim Stiles \& all others the present proprietors Inhabitants of Stratford their heirs \& assignes forever \& to the only proper use \& behoofe of the said Capt William Curtice Mr Joseph Hawley Mr Isaac Niccols Mr Jeremy Judson Luet John Beardsly Ensign Steren Burret Sargt John Curtice Mr Richard Blackleach Mr Timothy Wilcockson Mr John Wells Mr Samuel Sherman \& Mr Ephraim Stiles \& all others the present proprietors Inhabitants of Stratford their heirs \& successors \& assignes forever according to the Tenor of his Maties Manor of east Greenwich In the County of Kent in the Kingdom of England in free and common sociag \& not in Capitee nor by Knight Service they yielding and payeing therefore to or Soveraigne Lord the King his heirs and successors onely the fifth part of all the oare of Gold \& Silver which from time to time and all times hereafter shall be there gotten had or obteyned in leiv of all rents services dutys and demands whatsoever according to charter in Vitness whereof we have caused the Seale of the colony to be here unto affixed This Fourteenth of May One Thousand Sis Hundred eighty \& Six in the second years of the Reigne of our Soveraigne Lord Tames the Second by the Grace of God of England Scotlant France \& Ireland, King defander of the fayth \&r.

Robert Treat Governor.

Entered in the Record of the Town of Stratford Lib 2nd Folio 489. May 19, I686 pr Joseph Curtice Recordr. 


\section{MACKENZIE.}

George Norbury Mackenzie, II, born at Baltimore. Md., May 4, I85I, married (firstly) April 15, I874, at the Cathedral, Baltimore, Lucie Tennille Emory, born March I, I855, died June 27, I900, daughter of Ambrose Marechal and Mary (Tilyard) Emory, of Baltimore, Md., married (second), June I4, I902, at Corpus Christi Church, Baltimore, Mary Elizabeth Forwood, born May I2, IS74, daughter of William Smithson and Rebecca (Glenn) Forwood, of "Glenn Wood," Belair, Hartford County, Md.

Issue by first marriage:

I. George Norbury, III, architect, born April 2, I875, married by Rev. Eben Maynadier, December 2, I898, Sara Roberta Maynadier, born February 9, I878, only daughter of Hon. George Yellot and Sara Paca (Moores) Maynadier, of Belair, Md. (See Maynadier, Col. Fam. I907.)

2. Mary Gertrude Mackall, born March I3, I879, baptized March 22, I879, by her godfather, His Eminence, James Cardinal Gibbons; married September I9, I903, at Corpus Christi Church, Louis William Jenkins, son of Francis Xavier and Laura (Talbot) Jenkins, of "Montpelier," Prince George's County, Md. (See Jenkins, Col. Fan. I907.)

3. Colin Evan Williams, born June I5, I882, died Septembœr I9, I882.

4. Anna Vernon, born May 22, I887.

5. Katharine Tennille, born November 22, I889, died July 4, I890.

Issue by second marriage :

I. Thomas, IV, twin, born January 28, I906, died July I7, I 906.

2. Rebecca Forwood, twin, born January 28, 1906, died July II, I906.

3. Cosmo Glenn, born May 22, I907.

George Norbury Mackenzie, attorney-at-law, of Baltimore, Md., graduated at Pembroke Academy, Baltimore, I867. LL.B. 
University of Maryland, I890. Registrar General Society of Colonial Wars since 1892 ; founder and Lieutenant Governor of Maryland Society of Colonial Wars; founder and Governor, Society of The Ark and The Dove; Honorable Lieutenant Seaforth Scottish Archers; Grand Marshal Colonial Order of Acorn; Assistant Historian General, Military Order of the French Alliance of United States and France; Historian General, Americans of Royal Descent; founder of Maryland Commandery Military Order of the French Alliance; Charter Member and Ex-Registrar, Maryland Society Sons of American Revolution; Charter Member Maryland Society War of I8I2; member of the Baronial Order of Runnemede; Secretary Maryland Branch American National Red Cross; former Secretary Maryland Historical Society; former member American Historical Society; Charter Member National Genealogical Society; Vice-President for Maryland, Old "Northwest" Historical and Genealogical Society; former member of Maryland Society of New York; member National Geographic Society; St. Andrew's Society ; Charter Member Baltimore Country Club; engaged in many prominent business enterprises during the past thirty years; member City Club and Belair Country Club, and former member of Maryland, Merchants' University, and Baltimore Clubs, etc.

Eligibility for membership in Order of Washington derived through Colonel Joseph Williams, of Roxbury, Massachusetts, born April I0, I708, died May 26, I798; Colonel in the Mohawk War, I755, and the Canada Campaign, I758-60; member of the Massachusetts Provincial Council from Roxbury, I760 to I769; as representative from Roxbury, urged the repeal of the Stamp Act; was one of the first members of the "Sons of Liberty," Chairman of the Committee that waited on Lieutenant Governor Hutchinson, after the "Boston Massacre," March 7, I770, demanding the withdrawal of the British troops from Boston; Muster Master of the "Minute Men" for the town of Roxbury, March 6, I775. May, I775. one of the officers of the "Main Guard," in camp at Cambridge. For ancestry see Colonial Families, U. S. A., Vol. T, 
(1907) pp. 597-8. For Lineage of George Norbury Mackenzie, see Colonial Families, U. S. A., Vols. I. and II., Americans of Royal Descent, by C. H. Browning: Year Book, I9I4, Baronial Order of Runnemede, etc., etc.

Arms: Azure, a stag's head, caboosed, or, Crest: A dexter naked arm, embowed, grasping a sword, ppr.; Motto: Fide Parta Fide Actua; Residence: I808 Park Avenue, Baltimore. Md.

\section{McBRYDE.}

Charles Neil McBryde, born in Albemarle County, Virginia, near Charlottesville; moved to Columbia, S. C., when quite young. Prepared for college at the Columbia Classical Academy. Entered the University of South Carolina and completed undergraduate course at this university. Pursued graduate studies in chemistry and biology at the Virginia Polytechnic Institute. Studied medicine at the Johns Hopkins University, and later pursued advanced studies in preventive medicine and biology at the George Washington University. Holds the following degrees: Bachelor of Science, University of South Carolina; Master of Science, Virginia Polytechnic Institute; Doctor of Mecicine, Johns Hopkins University; Doctor of Philosophy, George Washington University.

Was appointed on staff of the Johns Hopkins Hospital, but resigned. Practiced medicine for several years after receiving medical degree, but gave up medical practice to take up scientific work in bacteriology. IVas appointed Bacteriologist in the U. S. Department of Agriculture in IOOI. Is at present Senior Bacteriologist in the U. S. Department of Agriculture, having charge of the bacteriological investigations of meats 
and meat food products. Has published numerous scientific papers and monographs dealing with diseases of animals, and with problems connected with the curing and canning of meats. Is a member of the following societies: Society of American Bacteriologists, American Public Health Association, American Association for the Advancement of Science, Washington Academy of Sciences, Biological Society of Washington, Anthropological Society of Washington, National Geographic Society, Washington Society of the Fine Arts, Scottish St. Andrews Society, Deputy Vice-Commander, Order of Washington, District of Columbia.

Represented the Department of Agriculture at the meeting, held in Havana, Cuba, in I9I I, of the American Public Health Association, an association composed of the public health officials of the United States, Canada, Mexico, and Cuba. Was a member of the Sixth International Congress on Tuberculosis, and of the Fifteenth International Congress of Hygiene and Demography. Is a member of the Cosmos Club, the University Club of Washington, and the Washington Country Club.

Charles Neil McBryde is the third son of John McLaren McBryde, Ph.D., Sc.D., LL.D., born at Abbeville, S. C., I84!, and Cora Bolton, born in Richmond, Va., I839.

Dr. J. McL. McBryde was professor in the University of Tennessee, President of the University of South Carolina, and of the Virginia Polytechnic Institute, of which he is now President Emeritus. He declined the presidency of the University of Tennessee, of Sweet Briar Institute, Virginia, and of the University of Virginia; also the Assistant Secretaryship of the U. S. Department of Agriculture.

The McBryde and Bolton families have their descents as follows :

McBryde, according to the Brittanica Encyclopedia, "An ancient family in the County of Galloway (Scotland)." Intermarried with the McDowells, Donnans, and other old families of that county.

Alexander McBryde, Merchant-Burgess of Stranraer, left 
in 1667 the estate of Auchinvie, in the parish of Port Montgomrie, to his son-

John McBryde, admitted a free stapler of Belfast, Irelanı', in 1644. Signed the covenant at Hollywood in 1666. His son-

Rev. John McBryde, or McBride, died I718. Married Margaret - was a distinguished author and Pres-. byterian divine at Belfast, and at Bogue (Scotland), in 1689. Graduated at the University of Glasgow in 1673 , and refused the chair of Theology in the University. His son-

Rev. Robert McBride, born I687, died I759, married Mary Boyd, was an equally noted author and Presbyterian divine at Ballymoney, Ireland. His eldest son, David, was a famous Irish surgeon and medical writer, and his second son, John, died I80o, was an Admiral in the British Navy, and Member of Parliament, whose son, John David, was Principal of Magdalen Hall, Oxford. Robert's third son--

Andrew McBryde, married Katherine Bennoch, and occupied the Mickle Tongue Farm, about I730. His son-

John McBryde, married in I796, Margaret Donnan, a member of an old Galloway family, descended from Adam and Arthur de Donnan, who signed, as nobles, the Ragman Roll in the time of Edward I. He occupied the same farm as his father. His son-

John McBryde, born 1802 , died 1865 , married in 1836 , at Abbeville, S. C., Susan H. McLaren, born I8I4, died I843, emigrated with his elder brothers. Andrew and James, about i820, and settled as Commission Merchants and cotton buyers in Augusta, Ga. He afterwards moved to Abbeville, S. C.

Susan H. McLaren, was the daughter of Adam McLaren, born 1777, died I826, and Agnes McKillop, born I777, died I85 I, married 1796.

Adam McLaren, a resident of Stirling and Glasgow, was a member of a family originally from Balquidder, in Argyleshire, to which belonged the late Bishop McLaren, of Chicago. $\mathrm{He}$ emigrated with his wife and family about I8I5-1820, anrl settled in Abbeville, S. C. He was the son of Neil McLaren and Susan Gibson. His wife was the daughter of Walter 
McKillop and Janet Hutton. One of Susan McBryde's brothers was Surgeon and Lieutenant Colonel in the U. S. Army, and another, Postmaster and a cotton planter in South Carolina. One of her sisters married Major D. D. Baker, of the U. S. Marine Corps.

John McBryde left two surviving children, Dr. John McLaren McBryde, as above, and Rev. Dr. Robert James McBrydis.

The Bolton family claims lineal descent from the Saxon earls of Mercia, through Oughtrede de Bolton, temp. Henry I. Robert Bolton, of the Manor of Little Bolton, Lancashire, England, mentioned I487, married Ann Rushton, daughter of Nicholas Rushton. His son-

William Bolton, died I553, of Little Bolton, married Elenor Asheton, daughter of Ralph Asheton, Lord of the Manor of Great Lever, and Elena Hulton. His father, Ralph, a second son, married Margaret Lever, heiress of Great Lever. The Ashetons were one of the most distinguished families of Lancashire, intermarrying with the Byrons, Harringtons, etc. William Bolton's son-

Adam Bolton, of Blackburn, mentioned in I 539, had a son--

Richard Bolton, mentioned in I545, lessee of the Brookhouse, Blackburn. Richard's son-

Adam Bolton, of the Brookhouse, married Elizabeth, and died in I539. Adam's son--

Gyles Bolton, of the Brookhouse, married Margaret, and died in I621. Gyles' son-

John Bolton, gentleman, of the Brookhouse, was born in I6I5, and died in I688. John's son-

John Bolton, of Wales, Yorkshire, born 1658, died I7I4, married Ann, who died in I7I4. John's son-

Robert Bolton, born I688, died I742, emigrated in I7 I8 and settled as a merchant in Philadelphia, $\mathrm{Pa}$. In I72I, he married Ann Curtis, born I690, died I747, the widow of Robert Clay. Her brother John was a judge of the Supreme Court of Pennsylvania. Her father, Winlock Curtis, was a son of John Curtis, a large landowner in Pennsylvania, and descended 
from an ancient family, long resident at Appledore, in Kent, England, who married Ann Bowers, a daughter of Benanuel Bowers, a landowner in Cambridge, Mass., and a son of George and Barbarine Bowers. George Bowers was in Scituate, Mass., by 1637 . He died in 1656 and his wife in I644. Ann Bowers' mother was Elizabeth Dunster, an emigrant to Massachusetts along with her father about I64I-I645. She married Benanuel Bowers in 1653 . Her father, Henry Dunster, of Elton, born I592, came to Massachusetts with his daughter and was a cousin of Henry Dunster, the first president of Harvard Coslege. Henry Dunster was son of Henry Dunster, born I560, sometimes called of Elton, and was called it seems of Baiehout.

Robert Bolton, the immigrant, was Senior Warden of Christ Church, Philadelphia. His daughter, Mary, married James Habersham, Governor of Georgia. His two surviving sons were Robert and John.

Robert Bolton, born 1722, died I789, became a wealthy merchant in Savannah, and landowner, and was Postmaster of the Province of Georgia. He also fought in the Revolution. He married in 1747 , Susannah Mauve, born I729, died I76.4, the daughter of Mathiew and Jane Mauve, wealthy emigrants from Switzerland to Savannah. Mathiew Mauve died in 1777. Robert's son-

Robert Bolton, born I757, died I802, was a large importing merchant of Savannah. In I78I he married Sarah McLean, born I757, died I806, widow of Dr. Jackson and daughter of James McLean and Frances Lewis of Chestertown, Md. James, who died in 1783 , was the son of James McLean, an emigrant from Ireland about 1720 , who settled on an estate called the Grove, near Chestertown.

Robert Bolton, the emigrant's second son-

John Bolton, born I726, died I784, settled on a large estate near Chestertown, Md. He took an active part in the Revolution and was Commissary of Kent County, Md. In I77 I he married Eleanor Dougherty, who died in 1784 . His son-

John Bolton, born I774, died I828, moved from Maryland to Savannah, Ga., where he married in 1804 , his first cousin, 
once removed, Sarah Bolton, born I782, died I85I, the daughter of Robert Bolton and Sarah McLean, and became a partner in his father-in-law's large importing house. He was mayor of the city. Later he moved to New York, where he became a leading citizen. His son-

James Bolton, born I8I 2, died I869, was educated at Columbia University and became a distinguished physician and surgeon in Richmond, Va. In 1838 he married Anna Maria Harrison of Richmond, Va., and their daughter Cora married John McLaren McBryde.

Anna Naria Harrison, born I8I3, died I880, was the daughter of Philip Harrison, born I $78 \mathrm{I}$, died 1852 , and Maria Lawson, born I789, died I849, married I8Io, Philip Harrison, an eminent lawyer in Richmond. Va.; was the son of Rer. Thomas Harrison of Fair View, an Episcopal clergyman, born I749. died I8II, who married in I775 his first cousin once removed, Sarah Harrison, born I754, died 1842 , the daughter of Captain Cuthbert Harrison of Fair View, died 1783 . and Frances $O_{3-}$ born Barnes, married 1738 , the daughter of Mathew Barnes of Maryland, and Mary Waugh.

Rer. Thomas Harrison was the son of Thomas Harrison. born I723, of Hunting Creek, a Burgess from Prince William County. He married in I747 Ann Waye Peyton, born I73I, daughter of John Peyton of Stoney Hill, born I69i, died I 760 , and Ann Waye, married I730, died I750. John Peyton was a Burgess from Stafford County and a close friend of Washington's. John's father-

Henry Peyton, born I656, married about I686 and settled on an estate in Stafford County. Va. His father-

Henry Peyton. born I631, died I659, married about I655, Ellen Partington, daughter of Richard Partington of London, Eng. Henry emigrated from Iondon to Westmoreland County, $\mathrm{Va}$., in 1656 . His father-

Henry Peyton, born I599, died 1656, of London, Eng., was of Lincoln's Inn and an armiger. He was a cadet of the family of Perton of Iselham and was probably $\mathrm{I}$ 7th in descent from Reginald de Perton, who died in I 36. 
Thomas Harrison of Hunting Creek, who married Ann Peyton, was a son of Burr Harrison of Chappawamsie, born I699, a Colonel of militia in Prince William Co., who married in I722, Anna Barnes, daughter of Mathew Barnes and Mary Waugh. He was brother of Cuthbert Harrison, who married his wife's sister. Burr's father-

Thomas Harrison, born 1665 , died 1746 , was a Captain in the Stafford Militia. Thomas' father-

Burr Harrison, baptized in St. Margaret's Church, Westminster, Eng., in 1637 , emigrated to Westmoreland County, $\mathrm{Va}$, before 1670 and was a large landowner there. He was an embassador to the Piscattaway Indians. He was the son of-

Cuthbert Harrison of England, undoubtedly a member of the old Yorkshire family of the Harrisons of Acaster and Caton-the arms of the Virginia family being the same as those of the Yorkshire.

Maria Lawson, wife of Philip Harrison and grandmother of Cora Bolton McBryde, was the daughter of John Lawson, born I754, died 1823, clerk of the Court of Stafford County, Va., and Mary M. Tyler, born I764, died I837. Mary Tyler was the daughter of Charles Tyler and Ann Moore, the daughter of William Moore. Charles Tyler was the son of Henry Tyler and Eleanor Middleton, daughter ofMiddleton and —_ Mann.

Ancestors; Immigrants Before the Revolution, With Date of Arrival.

George Bowers-to Massachusetts, before I6.37.

Henry Dunster-to Massachusetts, about I645.

John Curtis-to Pennsylvania, before 1650.

Henry Peyton-to Virginia in I656.

Burr Harrison-to Virginia before I670.

Robert Bolton-to Pennsylvania in I7 8 .

James McLean-to Maryland about I720.

Mathiew Mauve-to Georgia, I740. 
George Bowers, Henry Dunster, John Curtis, Henry Peyton, Burr Harrison and James McLean, of the foregoing were landowners; possibly the other two also.

Of Robert Bolton, the Immigrant's two sons, Robert was Postmaster of Georgia and fought in the Revolution and John was Commissary of Kent Co., Md., in the same war.

The first Thomas Harrison was a Captain, his son Burr a Colonel, and his son Cuthbert a Captain in the Virginia militia.

John Peyton and his son-in-law, Thomas Harrison, were members of the Virginia House of Burgesses. Thomas' son was an Episcopal clergyman. The first Burr Harrison was an ambassador to the Indians and John Lawson was clerk of a colonial court.

\section{McCOWAN.}

Robert Joseph Foster McCowan was born in Bridgeton, New Jersey, February 24, 1887, and is the son of George W. McCowan and Emma Bodine Foster, daughter of Henry Rulon Foster, son of Jeremiah Austin Foster, son of Jeremiah Foster, and Priscilla Preston, daughter of Col. Isaac Preston, of the Revolutionary War, son of Isaac Preston, born I707, overseer of roads, son of Levi Preston, born I662, constable, son of Roger Preston, who emigrated to this country in 1635 , and was a landowner in Salem, Mass.

$\mathrm{He}$ is directly descended from a number of Colonial and Revolutionary ancestors, in different lines; some of these lines can be traced in the old world for many generations. The names of Preston, Shute and Foster are particularly connected with local history, in the order given. Colonel Preston was in the campaign which included the battle of Trenton, 
N. J., where he suffered from exposure to the extent that he died at the "Forks of the Raritan," in Somerset County, March $5^{\text {th }}$ or 6 th, 1777 .

The subject of this sketch graduated at the Bridgeton High School, receiving the prize for highest standing among the male students; later he attended South Jersey Institute, and at present is connected with the designing department of Fe:racute Machine Works, Bridgeton, N. J.

\section{MARTIN.}

George Castor Martin, of "Allardyce," Asbury Park, N. J., born in New York City March 30, I885; son of Richard Allen Martin, M. D., of Philadelphia, New York and Boston, who was born October 2, 1858 , in Philadelphia and who died March I7, I890, in Boston. Richard Allen Martin married. December 6, I883, at "Inwood," Conshohocken, Pennsylvania, Nellie Mills Castor, daughter of George M. Castor and sister of the Hon. George A. Castor.

George Castor Martin married, first, Mildred, daughter of Henry Comegys, September 22, I906, and, second, March I6, 1912, at Wilmington, Delaware. Violet Towers, daughter of Albert Coates, of Philadelphia. Issue (first marriage):

I. Richard Allen Allardyce Martin, born July I5, 1907 .

Issue (second marriage):

2. Mary Castor Ball Martin, born April 5, I9r3.

Club--Asbury-Belmar Country Club.

Societies-Order of Washington (Vice Deputy Commander, N. J.) : Pennsylvania German Society; Sons of the Rerolution; Sons of the American Revolution; Frankford Historical Society (Director).

Military Service-22nd Regiment Engineers, N. Y., five years; 7 Ist Regiment Infantry, N. Y. (present membcr). 
Author of The Martin Family, The Castor Family, Barrett Ancestry, The Shark River District, etc., etc.

First American ancestors:

I. Samuel Martin, I760-I829, Philadelphia, Pa., I828.

2. James Thornley, Philadelphia, Pa., I829.

3. Georg Castor, John George Castor, or Hans Georg Gerster, I7IO-I797. Philadelphia, Pa., I736.

4. Joseph Northrup, died I669, Milford, Conn., I639.

5. George Mills, died Philadelphia, I854.

6. John Burrage, I6I6-I685, Charlestown, I632.

7. John Howell, died I721, Philadelphia, Pa., I697-8.

8. Robert Haydock, born I687, Wilmington, I743, Philadelphia, Pa., I744.

9. William Ward, died I687, Sudsbury, Mass., I639.

Io. Nicholas Stowers, died I646, Salem, Mass., i629.

I I. Major General Humphrey Atherton, I599-I66I, Boston, Mass., i635.

12. Thomas Trowbridge, who is first recorded in New England in I636, returned to England, where he died, February I7, I662. Descent of Geo. Castor Martin is through Deacon Tames Trowbridge, of Dorchester, etc., etc., etc.

\section{MIEREDITH.}

William Payne Meredith is the son of Elisha Edward Meredith and Sylvia Drayton Contee, of Maryland, and has the following descent:

"Covernor Yeardley arrived in Virginia, as Colonial Govcrnor on the I8th day of April, I6I9, and also in the same ship arrived Sir Robert Payne, John Payne and William Payne."

The above was taken from Smith's history of Virginia, found in the Library of William and Mary College, Williamsburg, Va., in 1855 .

John Payne, who arrived in I6I9, lived near Leedstown, Westmoreland Co., Ya. His son, Richard Payne, married a Miss Monroe of Eastlass Land of the Elms, Lancaster County, Va. They had four sons, George, William, Richard and Danisl. 
George Payne, born I727, married Frances Stone of Maryland. They had six children, William, George John, Richard, Daisy and Nary. William married Susannah Richards; they had two children, Frances Stone Payne who married Mr. Scott of Scotland and Fredericksburg, and Daniel Payne. Daniel Payne married Elizabeth Hooe Winter of Maryland. They had six children; they are as follows: William Winter Payne, Richards, Rice W.. Elizabeth Hooe Winter, Scott and Albin.

Elizabeth Hooe Winter Payne married John Taylor Meredith. They had seven children, Richard, Elisha, Edward. Thomas Semmes, Frank, John Cabell, Elizabeth and Alice.

Elisha Edward Meredith married Sylvia Drayton Contee, of Maryland. They had two children, Edward Contee Mere-dith and William Payne Meredith.

Captain William Payne, the great, great grandfather of William Payne Meredith, organized and commanded the "Falmouth Blues," of Fredericksburg, Virginia, during the Revolutionary War, and is highly spoken of in the standard histories of the United States.

Lieutenant John Contee, U. S. N., born I8ı6, died I864, was a son of Lieutenant John Contee, U. S. Marines, born I794. died I839; a grandson of Richard A. Contee, ensign in the Revolution, born about I753, died I8I8: a great grandson of Colonel John Contee, born about I722, died I796, signer of the "Association of the Freemen of Maryland," July 26, I775; and a great, great grandson of Alexander Contee, the immigrant, who settled in $\mathrm{M}$ Iaryland about $\mathrm{I}_{705}$, and was Clerk of the County Court of Prince George's County for many years and in I724 was elected a member of the Lower House of the General Assembly.

Lieutenant John Contee married Eliza Duckett, daughter of Isaac Duckett and Margaret Bowie. The Ducketts were a prominent family. Margaret Bowie, was a daughter of Walter Bowie and Mary Brookes (not Brooke), daughter of Benjamin Brookes and Elizabeth Townley. Walter Bowie was very prominent during the Revolution and was twice Congressman. He also signed the Association of Maryland Freemen. 
His father, Captain William Bowie, was on June 22, I774, a delegate from Prince George's County to the Annapolis Cor1rention. Walter Bowie's mother was Margaret Sprigg, daugh ter of Osborn Sprigg, who was a member of the Lower House, I739 to I744; High Sheriff of Prince George's County, I747 to his death in 1750 . His father, Lieutenant-Colonel Thomas Sprigg, was a member of the Lower House, I7 I 2 to I7 I5, and Justice of the Peace from I697 to I704. He in turn was a son of Thomas Sprigg who emigrated to Maryland about I657 and was a Justice of the Peace, I658 to 1674, and High Sheriff of Calvert County, I66+ to $166_{5}$.

Richard A. Contee married a Mrs. Sanders. R. A. Contee's father, Colonel John Contee, married Margaret Snowden. Alexander Contee's wife was Jane Brooke, daughter of Colonel Thomas Brooke, member of the Council of Maryland, I692 to I724. Justice of the Provincial Court, I694. Deputy Secretary of Maryland, I695. Commissary General, I70 I, and President of the Council and Acting Governor of Maryland, I720. Jane Brooke's grandfather was Thomas Brooke, Major of Militia, I650, member of the Lower House, I663-1676; High Sheriff of Calvert County, I666-I660; and Presiding Justice of the County Court, I667. Her great grandfather was the emigrant, Robert Brooke, Commander of Charles County, and member of the Council of Maryland, I649, and head of the provisional government of Maryland under the Parliamentary Commissioners."

\section{MIDDLETON.}

Arthur E. H. Middleton, born Pensacola, Fla., July 25, I872. Son of Edward Middleton and Ellida J. Davison, son of Henry Middleton and Mary H. Hering, son of Arthur Middleton and Mary Izard, son of Henry Middleton and Mary Williams, son of Arthur Middleton and Sarah Emory, son of Edward, son of Henry.

Arthur Middleton first named was signer Declaration of Independence. 


\section{MONNETTE.}

Orra Eugene Monnette, banker, residence 3IOI Wilshire Boulevard: Office 308-Io South Broadway, Los Angeles. Cal: born near Bucyrus, O., April I2, I873; son of Mervin Jeremiah and Olive Adelaide (Hull) Monnette; married to Carrie Lucile Janeway in 1895; graduated from union schools. Bucyrus, O., I890; attended business college, Bucrrus, O.; graduated from Ohio Wesleyan Univ., Delaware O., B. A. (special course in law), I895: first business training was in Second National Bank, Bucyrus, O.; admitted to practicie law in 1896 , in all Ohio and U. S. district courts; formed partnership with Judge Thomes Beer and Smith IV. Bennett, under firm name Beer, Bennett \& Monnette, Bucyrus, O., I897 ; Bennet retired from firm in 1899 , and partnership was Beer and Monnette until October, I903, when Monnette removed to Toledo, O ; formed partnership with Hon. Charles A. Seiders, Toledo; the latter connection continued until I906, when Monnette withdrew from firm and opened offices alone: moved to Los Angeles, Cal., I907, and continued law practice alone until I9I2, when he was elected president of Citizens Trust \& Savings Bank: director Citizens National Bank of Los Angeles ; Citizens Trust and Sarings Bank: Los Angeles Title \& Trust Company; Mortgage Guarantee Company: has done literary work, and in I9I I published "Monnet Family Genealogy" ( I300 pages, I 7 illustrations, large royal octavo) at cost of ten years' labor and \$I0,000. Menber Society of Mayflower Descendants: Huguenot Society of America; Sons of the Revolution: Society of Colonial Wars: Sons of the American Revolution; Order of Washington: Society of the War of I8I2; Phi Beta Kappa (honorary scholastic), and Phi Kappa Psi fraternities; elected national president of latter, June, I9I I ; Masonic fraternity, 32d degree Scottish Rite: Shrine: California, Jonathan, Union League, Los Angeles Athletic, Los Angeles County, Knickerbocker and Los Angeles Ad clubs; Order of Moose: Republican; Methodist.

Taken from "Who's Who, in the Pacific Southwest." 
A Personal Dicionary for the Year I9I3, page 262. (Taken from Colonial Families of the United States of America, George Norbury Mackenzie, Vol. III, p. 337)

Orra Eugene Monnette, B. A., born April I2th, I873, at Bucyrus, Ohio; married November 6th, 1895, at Columbus, Ohio, Carrie Lucile Janeway, born August 3d, 1875, daughter of William Francis and Anna (Eaton) (Elrick) Janeway, of Columbus. Ohio.

Orra Eugene Monnette removed from Bucyrus to Toledo, Ohis, in 1903, and from the latter place to Los Angeles, Cal., in April, 1907; educated at Ohio Wesleyan University, Delaware. Ohio, I895; degree B. A., special law, and elected to Phi Beta Kappa; admitted to the Bar in 1896 . and in active practice until January, I9I2; National Secretary, Phi Kappa Psi Fraternity, 1898-1906, and elected President of same, June 29th, I9I2. Thirty-second Degree Mason, member Scottish Rite bodies and Mrstic Shrine, President Citizens Trust and Sarings Bank, Los Angeles, Cal.; Treasurer Mortgage Guarantee Company of Los Angeles, Cal. ; compiler of "Monnet Family Genealogy" (I9II), 8vo., I300 pages, I7I illustrations.

\section{LINEAGE.}

The Monnet family is of Huguenot ancestry, and had its origin in France. The name in Latin is "Moneta," and forms in France "Monet" nad "Monnet," changing to "MIonnett," in America. The family is descended from La Noble Maison de Monet de La Marck, Seigneurs et Barons, from the year 1632, and the Seigneurs de Monnet, La Maison de Salins, from the year II84. Its direct lineage is traceable back to Pierre Monnet, Protestant, massacred on St. Bartholomew's Day. I572, who was from the ancient Province of Poitou. A descendant, Pierre Monnet, and his two sons, Pierre and Isaac, became refugees, circa I686, settling in London. Before I 700 , the sons emigrated to America.

Isaac Monnet, the elder, settled in Calvert County, Md., before 1707 , at which date he possessed land and was enrolled on Lord Baltimore's Rent Roll. Held military commission for county, died circa $1748-49$, and was buried in Old Christ 
Church graveyard; married Elizabeth Williams, daughter of William and Sarah Williams, of Calvert County, Md.

Had son, William Monnett, whose son was Isaac Monnett, who had Abraham Monnett, who had Rev. Jeremiah Crab Monnett, who had Abraham Monnett, who had Mervin Jeremiah Monnett.

Arms: Quarterly, first and fourth, azure, a bend or; second and third, or, a lion rampant, gules.

Crest: A demi-lion rampant, gules.

Supporters: Dexter, a lion rampant, gules; sinister, the same.

Motto: Florens suo orbe monet.

Residence: 3Ior Wilshire Boulevard, Los Angeles, Cal.

Clubs: Jonathan, Los Angeles County, Los Ángeles Athletic, Union League, and Knickerbocker.

Societies: Mayflower Descendants, Colonial Wars, Sons of the Revolution, Sons of the American Revolution, Society of the War of I8I2, Huguenot Society of America, Order of Washington.

\section{MUNCASTER.}

Dr. Steuart B. Nuncaster was born in Georgetown, District of Columbia; attended the Rockville Academy, MIontgomery County, Maryland, and graduated as a physician from the School of Medicine of Georgetown University in 1885 . After practicing medicine for a time he took up as a specialty the diseases of eyes and ears. He went to the Polyclinic in New York and then spent two years and three months at the hospitals in Paris, Vienna and London, in order that he might fit himself for the practice as a specialist of the eye and ear. He returned to Washington and began the practice of his specialty in I890. Dr. Nuncaster is a member of the follow- 
ing societies: Medical Society of District of Columbia, American Medical Association, Opthalmological and Otological Society of District of Columbia, and one of its late Presidents; Medical and Chirurgical Faculty of Maryland. American Association for Advancement of Science, Society of Colonial Wars, Sons of Revolution, Order of Washington, American Clan Gregor, Maryland Club, Rockville University Club, Masonic Fraternity, and other societies: Monday Evening Club, Alumni Society of Georgetown University.

Dr. Stewart B. Nuncaster was the son of Otho Zachariah Nuncaster and Harriet E. Magruder.

Grandson of Zadock Nagruder, attorney-at-law, and Rachel Magruder.

Crreat grandson of Dr. Zadock Magruder and Martha Magruder.

Great, great grandson of Colonel Zadock Magruder and Rachel Magruder.

Crreat, great, great grandson of John Magruder and Susannah Magruder.

Great, great, great, great grandson of Samuel Magruder and Sarah Beall.

Colonel Zadock Magruder was a Colonel in the Revolutionary War and was the son of John Magruder, the son of Samuel Magruder, who was in the Colonies from I676 to I 7 II, and received grants of land in Prince George County; was a nember of House of Burgesses in 1707-1708. In 1676 he was a military and civil officer of Prince George County, MId. His father settled in Calvert County. Maryland. in 1652 .

\section{MUNSON.}

Captain Thomas ${ }^{1}$ Munson, I612-1685, ancestor of the Munsons, in these United States, came from England. In 1637 
he was one of the forty-two men of Hartford, Conn., who served under Captain Mason in the Pequot War. He was of New Haven, Conn, where he signed the Fundamental Agreement, in 1639. He was Lieutenant in $1664-76$, served under Captain Treat, in the King Philip War. Captain in 1676 , New Haven militia.

Captain Thomas' was elected to the Plantation Court in I662. He was foreman of the first Grand Jury impaneled in New Haven, also member of the Supreme Court of Appeals. In $i 666$ he was elected Deputy to the General Assembly, serving in this capacity for 24 sessions.

Samuel ${ }^{2}$ Munson, baptized August 7, 1643 (New Haven First Church records), married October 26, I665, Martha, daughter of Williann and Alice (Priechard) Bradley. (Town Records) Samuel died in I693, Wallingford, Conn. (William Bradley - I69I, Deputy from New Haven to. the General Court of Connecticut, I665-I678-I680-I683). Samuel $^{2}$ Munson, with thirty-eight others, of New Haven, founded Wallingford, Conn. The General Court of Harttord on May 12, I669, "Doe grant liberty to make a village on the east River." Among the names signed to the agreement appear those of Samuel ${ }^{2}$ Munson, Thomas Yale, Thomas Curtis, Samuel Peck and John Peck, Joseph Benham, John Brocket, and Nathaniel How.

General Court, October 19, 1675, "This Court confirms Samuel Munson Ensigne Wallingford Traine Band."

Samuel $^{3}$ Munson, born February 28, I669, Wallingford, Conn., married Martha —_. She died January 7 , I707. Married widow of Caleb Merriman, daughter of Eliasaph Preston. She died November 28, I755. Samuel ${ }^{3}$ died November 23, I74I, age 73. Wallingford, Conn. He was Town Clerk of Wallingford for 29 years. In October, I712. the General Court divided the Traine Band of Wallingford, "Samuel Munson to be Ensigne of the West Company, or Traine Band."

William Munson, born October I3, I695. Walling ford, Conn., married Rebecca, daughter of Thomas Curtis, of WalJingford. William ${ }^{4}$ died July 2I, I773, at Waterbury, Conn.

Thomas Curtis, whose daughter, Rebecca, married William ${ }^{4}$ 
Munson, was born in 1648 , died in 1736 , Ensigne Wallingford Traine Band, I704, an original proprietor and signer of the Covenant, I669, Deputy Colonial Legislature, I689-I7 I4-I7 I7, Constable, I68I, Town 'Treasurer, I686. He married Mary Merriman, of Wallingford, June 9, I674-5. She was born in New Haven in 1657 , died in Wallingford.

John Curtis, father of Thomas, was born in Uazing, Essex County, England, i6ri, died in Stratford, Conn., I707, age 96. He married Elizabeth Welles; she died in Stratford, Conn., March 9, I68I-2. John Curtis was a soldier in King Philip's War, and attained the rank of Ensign. He was one of the original Patentees of Stratford, Conn., and in this Patent was called "Sergeant John Curtis."

William ${ }^{5}$ Munson, born July 5, I73I, Wallingford, Conn., married Sarah, daughter of Isaac Griggs, Wallingford, February 28, I753. He died May 26, I8I5; his wife died October 7 , I806, at Waterbury, Conn. William ${ }^{5}$ served in the Revolutionary War as a private. He enlisted May 26, I777, in Captain David Smith's Company, Connecticut Battalion, served three years, discharged May 26,1780 , as a private from Major David Smith's Company, 8th Connecticut Regiment Colonel Isaac Sherman.

Elisha ${ }^{6}$ Munson, born October io, I756, Waterbury, Conn., married September 3, I783, Mabel Homeston, daughter of Joy Homeston (Humestone). Elisha ${ }^{\circ}$ died in 1835, Prospect, Conn. Elisha ${ }^{\circ}$ enlisted with his father, William ${ }^{5}$, on the same day, company, and was discharged the same day, and company. The battles engaged in were Harlem, Germantown, and Fort Monmouth; Elisha ${ }^{B}$ was pensioned. Both were with Washington at Valley Forge.

Linus Joy Munson, born Prospect, Conn., about I800, married in I82 I, Lorene Weller, of Canton, N. Y. He died in I 835 ; his wife died in 1876 .

David Ezra ${ }^{8}$ Munson, born I832, Prospect, Conn., married, 1856, Amy Ockerman, of Belleville, Ont. (Her mother was Phebe Dunham). She is now living with her daughter in Los Angeles, Cal. 
Dunham Ockerman ${ }^{9}$ Munson, born Brockport, N. Y., June 29, I859, married in Greeley, Colo., November 23, I889, to Magdalen Begert, born in Brockport, N. Y. Dunham O. Munson, graduate of Marion Simms College of Medicine (St. Louis University). Has been in Pittsburgh, Kansas, present location, I6 years; has served as County Health Officer, County and City Physician.

Herbert Edwin'10 Munson, born Chillicothe, Ill., November 5, 1896 . Herbert is the only child of Dr. D. O. ${ }^{9}$ and Magdalen Munson.

The descendants of the Munson family have been noted as soldiers, ministers, statesmen, lawyers, and judges. (The Hon. Edward Pierpont, Attorney General of U. S., and Minister to England, his mother was a Munson). The Munson professions, for the last three or four generations, has been that of law and medicine.

PARKE.

Robert $^{1}$ Parke came with John Winthrop, in the ship "Arbella," to Boston, June I7, I630. He was born in Preston, England, I580. He married Martha Chaplin, daughter of William, at Semer, England, February 9, I60I-2. Robert Parke moved to Wethersfield, Conn., I639; to New London, I649, and died at Mystic, Conn., February 4, I664-5; was a Representative or Deputy to the General Court, I64I, I642 and I652; also held several other offices. His third son was-

Thomas ${ }^{2}$ Parke, born in Hitcham, England, February I3, I6I5, came with his father. He married Dorothy Thompson at Wethersfield, a daughter of John and Alice Thompson. He was one of the first proprietors and a large land owner in Preston, Conn., where he died July 30, I709. His second son was- 
Robert $^{3}$ Park, born in New London, Conn., about I65I. His first wife was Rachel Leffingwell, a daughter of L.t. Thomas L,effingwell, who he married November 24, I68I. He was a soldier in King Philip's War. He died in I707. His oldest son was-

James* Park, born in Norwich, Conn., about I685. He married Deborah Geere, March 27, I709, at Preston, a daughter of Jonathan and Mary (Allyn) Geere. He was Surveyor of Preston in I722, and died there about I726-7. His second scn was-

Robert ${ }^{-}$Park, baptized in Preston, August I8, I7I8. He married Mary, a daughter of Samuel and Elizabeth (Rose) Killam, at Preston, January 22, I744-5. They moved to near Westfield, Mass., where they died. Their third son was-

Reuben ${ }^{6}$ Parks, born at Preston, Conn., August I3, I755; lived at Russell, Mass ; married Betsey, daughter of Lt. James and Sarah Clark, at Murrayfield (now Chester), Mass., July 20, I777. He was in the Revolutionary War, in Capt. Malcolm Henry's Company, Col. David Brewer's (gth) regiment in I775. He died at Russell, September I4, I802. His fourth son was-

Sylvester7 Parks, born at Russell, Mass., April 8, I792. He married Laura, daughter of Ralph and Lydia (Snyder) Andrus, at Russell, I8I3, and moved to Palmer, Mass., where he was one of the Selectmen for several years. He died at Palmer, August 29, I858. His third son was-

Alonzo Henrys Parks, born at Palmer, Mass., October 28. i828. He married Julia Elizabeth, a daughter of Anson and Hannah King (Bancroft) Sanborn, at Palmer, October 5, I858. He died at Washington, D. C., January 4, I890, and is buried in Palmer. His second son was-

Frank Sylvester ${ }^{9}$ Parks, born at Palmer, Mass., December I3. I85I, resides in Washington, D. C., was educated in the common schools of Palmer and Washington, has been in the printing and insurance business, and for a number of years has been in the Navy Department. He has written a number of papers on genealogical and insurance subjects, and pub- 
lished a volume of 333 pages, in 1906, on the Parke Families, of Connectitut; followed by the Parke Families, of Massachusetts, a volume of 264 pages, in 1909. Is devoting his spare time, at present, on the Parke Families, of Pennsylvania. $\mathrm{He}$ is a member of the New England Historical-Genealogical Society, of Boston; the New London County Historical Society, of Connecticut; The National Genealogical Society, and several other societies and organizations. He married Mary, a daughter of John and Mary Ann (Moore) Lynn, at Washington, November 20, I888. Their children are: Marie Anne, Frank S., Paul J., and Thomas M. Parks.

\section{PARKER.}

Captain William Edward Parker was born in Newton, County of Middlesex, State of Massachusetts, March 21, 1876, an 1 is the son of William Chipman Parker and Emily Ann Goodwin, grandson of John D. Goodwin and Mary Augusta Tuttle, great grandson Cornelius White Tuttle and Mary Barnes and great grandson of John Barnes and Polly Negus great, great, great grandson of William Negus and Patience Hilleal.

William Negus was a veteran of the French and Indian Wars and was born in I73I. He received grants of land at Dummerstown, Vermont, was Town Assessor of that town in I774 and member of Captain Jason Duncan's Company during the Revolution. His father, Joseph Negus, was a direst descendant of Jonathan Negus, or Neguse, who went from England with the first settlers and was Surveyor of Boston, Mass., in 1649 , and rad a grant of Long and Spectacler Islands in Boston Harbor, in consideration of his public services. 


\section{CAPTAIN TIMOTHY PARKER.}

As the sketch of the Parker family, given in Vol. XVIII of the (Worcester Society of Antiquity) Society's Proceedings, contains no reference to the military service of Captain Timothy Parker in the Revolutionary War, for the benefit of our readers it is given here:

On page $18_{4}$, Vol. XVIII, is mentioned his service in the French and Indian Vars; but as captain, he was in command of a company of minute-men in Sturbridge, Mass., whither he remored from Roxbury before going to Holden. During ten years of struggle, through which the people had passed in striving for their rights, and had been driven step by step from love and reverence for the English government. to a stern belief that nothing short of a resort to arms would ever settle their troubles, and all citizens, even in remote towns, were making preparations for a fearful combat in a town meeting in Sturbridge, called to prepare for the emergency, September 28, I774, they voted to provide a large quantity of powder, 500 pounds of lead, and 500 flints; at the same meeting chose Captain Timothy Parker a delegate to the Provincial Congress, to be convened at Concord, and all men sixteen years old, and upward, were requested to "assemble at the meeting-house, with arms and ammunition, to be reviewed."

It was an extraordinary scene! The old men were formed in companies of "alarm men": the young men into "minutemen," ready to march at a moment's notice. Captain Parker had command of one company. Captain Newel of another, and Captain Crafts of another.

The instructions given the delegates were that "if the address to His Majesty was not accepted, we think it highly necessary to assume government, by and with the advice of our sister colonies, as soon as may be."

Sturbridge had voted to raise 100 pounds for the repair of roads, but they promptly reconsidered their country's oppression worse than bad roads. 
"Timothy Parker, Sturbridge, Captain of a company of minute-men, Colonel Warner's regiment, which marched April 21, I775, in response to the alarm of April 19, I775. Service, I4 days." This record is from the archives at the (Mass.) State House, Book II, page 907. He served in subsequent campaigns, gaining a reputation of a good officer and a staunch patriot.

\section{PETTIS.}

William Montrose Pettis, youngest son of Madison Pettis and Eliza Harwood Semple, born in Virginia, in I837, reared and educated in Williamsburg, in the Academy, and in William and Mary College.

Madison Pettis, born in Spottsylvania County, Va., oldest son of John Pettis and Sarah Reyno!ds, born in Spottsylvania County, in I75I. His father was a native of South Carolina, of a Huguenot family. John Pettis served in American Revolutionary army, from 1779 to 1782 , marched through the Carolinas, was at the battles of Guilford Court House, and Eutaw Springs, and was honorably discharged in Salisbury. in 1782 , after serving two years and six months.

Eliza Harwood Semple, daughter of James Semple and Sarah Harwood, born in Williamsburg in I795. Sarah Harwood, daughter of William Harwood, of Warwick County, Va., son of Humphrey Harwood, Burgess of Virginia from 1742 to 1776 , son of Thomas Harwood, son of William Harwoot, who owned and lived, in I623, at Martin's Hundred, a large estate located on James River between Hog Island and Mulberry Island, always in the Harwood family.

These Harwoods were distinguished for their services in the Virginia Colonial Government, and in the Revolutionary Army. 


\section{POULLAIN.}

James Potter Poullain is the son of Philip Poullain, a graduate of Princeton, son of Dr. Thomas Noel Poullain, who died in Greensboro, Ga., in I889, who married Harriet Byron Wray.

Philip Poullain married Katharine Elizabeth Potter, daughter of James Potter, a wealthy planter, on the Savannah River, in Georgia, who married Sarah Jones Grimes, daughter of Dr. John Grimes, of Savannah, Ga., and Catharine Jones Glen, daughter of Judge John Glen and Sarah, daughter of Dr. Noble Vimberly Jones, the ardent Revolutionary patriot. son of Hon. Colonel Noble Jones, of his Majesty's Council in Georgia, who arrived in the Colony in 1732 , and held many official positions.

James Potter was the son of John Potter, of Mount Potter, in Ireland, and went to Charleston, S. C., in $\mathrm{I} / 84$, where he married, on August 22, I79I, Catharine, daughter of Coi. Thomas Fuller and Catharine Foley, son of Richard Fuller and Nary Drayton, daughter of Thomas Drayton, and sister of Hon. Thomas Drayton.

Richard Fuller was a son of William Fuller, who was a member of the South Carolina House of Commons in I7 12.

\section{RAY.}

Preston Blair Ray was born February 22, I878, in Montgomery County, Maryland, where he still resides. After finishing the course at Columbian Preparatory School, he entered the George Washington University, graduating in 
I899. He entered the Law Department of the Catholic University, from which he graduated in I902. Served as Corporal in the Ist Maryland Volunteers during the Spanish-American War. Was elected a member of the Maryland Legislature in 1907, and was a member of the Democratic State Central Committee, from Igog to I9I2. He is a member of the Bar of Maryland, and of the District of Columbia, member of the Maryland Bar Association, also a member of the Phi Kappa Psi Fraternity. He is the youngest son of Alfred Ray and Eleanor Merryman Gatch. Captain Benjamin Merryman, of Monkton, Md., who commanded a company of militia in the Upper Battalion of Maryland, and known as a "Firm Patriot," was the Revolutionary Ancestor of Mr. Ray. Captain Charles Merryman, who settled in Baltimore County, Md., I682, received a commission in the Colonial Militia, of Maryland, and was his Colonial ancestor.

\section{RICHARDS.}

Henry Melchior Muhlenberg Richards, great, great grandson of Colonel Conrad Weiser (I696-I760), Head of the Indian Bureau of the Province of Pennsylvania, Lieutenant Colonel, commanding Ist Battalion, Pennsylvania Regiment during the French and Indian War. Great grandson of Henry Melchior Muhlenberg. D.D. (I7II-I787), the Patriarch of the Lutheran Church in America, and father of Major General John Peter Gabriel Muhlenberg, Continental Army, Frederick Augustus Conrad Muhlenberg, First Speaker of the United States Congress, etc., also Gotthilf Henry Emertus Muhlenberg, D.D., the eminent American botanist and clergyman. Grandson of the Hon. Major Matthias Richards ( I758I830). Son of the Rev. John William Richards, D.D., and wife Andora, nee Garber. 
The subject of this sketch was born in Easton, Pa., August I6. I848. He served during the Civil War, I863 and I864, in the battle of Gettysburg, with its campaign, and in West Virginia, under General Sheridan; "Star" graduate (highest honor) of the U. S. Naval Academy, I869; actively engaged in connection with the Franco-German War, of I870-7I, the Communistic Outbreak, and Carlist Insurrection, of the same period, and a threatened fanatical outbreak against the Christians in Tunis, Africa, I870; on duty at the U. S. Torpedo Station, Newport, R. I., I872, where he invented an earth-connection circuit-closing torpedo fuze, far in advance of any then in existence, which was adopted by the government; on duty in the Pacific Ocean, I873-74, under Commancler (now Admiral) Dewey, where he was actively engaged in the Revolutionary Outbreak at Panama, of April, I873; resigned December 3I, I8 74 ; volunteered for duty in anticipation of war with Chili, I892; served through the SpanishAmerican War, of $1 \& 9 \&$, under Admiral Sampson, about Cuba and Porto Rico, with the rank of Lieutenant (Senior). U. S. Navy.

After leaving the service, Mr. Richards became identified with the iron and steel business, and is now Treasurer and a Director of the American Iron \& Steel Manufacturing Conpany, with its General Offices at Lebanon, $\mathrm{Pa}$.

On June 28. I893. he was appointed, by the Governor of Pennsyliania, a Commissioner to locate the various forts, erected in said Province, prior to $I 78_{3}$, as defenses against the Indians, and is the author of many works of historical, genealogical and biographical character, most of which have become the standard authority on the subjects of which they treat.

In I9IO there was conferred upon him the degree of Doctor of Letters (Litt. D).

He is a member of The Authors' Club, of London, England. also of many prominent military, historical, genealogical and scientific societies.

On December 26, I87i, he was married to Ella Van Leer (von Loehr), with whom he has had issue of four children, 
Rev. H. Branson Richards, Dr. Charles M. Richards, Florence and Alice (Mrs. I. L. Bennetch (Basnage.)

\section{ROOSEVELT.}

Franklin Delano Roosevelt, Assistant Secretary of the Navy, was born at Hyde Park, Dutchess County, New York, January 30, I882, and graduated at Harvard College. Entering politics, he so distinguished himself as a Democrat, that he was recommended for and receired the appointment of Assistant Secretary of the Navy. Franklin Delano Roosevelt received the following degrees: A.B., Harvard, 1904: Columbia University Law School, I904-07; married Anna Eleanor Ronsevelt, of New York, March I7, 1905. Admitted to New York Bar, Ino7; practiced with Carter, Ledyard \& Milburn, New York, 1907-10; member firm Marvin, Hooker \& Roosevelt, I9II- ; member New York Senate, I9Io-Narch I7, I9I3 (resigned) ; Assistant Secretary of the Nary, March I7, I9I3- ; Democrat. Member Hudson-Fulton Celebration Commission, 1909, Plattsburgh Centennial, I9I3. Episcopalian. Trustee Laura Franklin Free Hospital for Children. Seamen's Institute. Nember Naval History Society, New York Historical Society, Holland Society, Alpha Delta Ph: Mason. Clubs: City, Harvard, Knickerbocker, Racquet \& Tennis (New York), Army \& Navy, Metropolitan, University (Washington). Home: Hyde Park, Dutchess County, N. Y.

$\mathrm{He}$ is the son of James Roosevelt and Sara Ann Delano, grandson of Isaac Roosevelt and Mary Rebecca Aspinwall; 
great grandson of Jacobus or James Roosevelt and Maria Eliza Walton; great, great grandson of Isaac Roosevelt, born December I9, I726, died October, I794, and Cornelia Hoffman; great, great, great grandson of Jacobus, or James Roosevelt, baptized I692, elder in Reformed Church, and Catharine Hardenbroeck; great, great, great, great grandson of Nicholas Roosevelt and Heiltje Jans Kunst, son of Claes Martinsen Van Roosevelt, who came to America I649-I650.

Isaac Roosevelt, born in 1726 , enlisted as a private in the 6th Regiment, Dutchess County militia. He was elected, April 22, I775, a member of the Provincial Congress. Elected, on May I, I775, as one of the gentlemen of a general committee for the County and City of New York, and at the same time chosen one of the deputies of the other counties in Provincial Congress, May 22. He was one of the most noted Whigs of the time. One of general committee of One Hundred, to take control of government, etc., etc.

Nicholas Roosevelt, the lineal ancestor of Isaac Roosevelt, was in the Colonies from 1658 to July 30,1742 . He was a Burgher of the Major right, Alderman of the Leislerian Party, I700-I70I, also Alderman. I698-I70I, and Alderman for the West Ward in I755. We thus see a long line of ancestry, embracing the families of Roosevelt, Delano. Aspinwall, Walton, Hoffman and Hardenbroeck, ancient families of New York.

\section{RUTTER.}

Wrilliam Ires Rutter, Jr., son of William Ives Rutter, I836I9IO, and Sarah May (Hobart) Rutter, daughter of Robert Enoch Hobart and Henrietta Williamina Smith, his wife. Great, great, great, great grandson of Thomas Rutter and Rebekah Staples, his wife; settled in Philadelphia in 1685 ; bailiff of Germantown I706 (succeeding Pastorius); member Provincial Assembly, I7I3-I4-27-28; the first to make iron in Pennsylvania. Great, great, great grandson of Thomas Rut- 
ter, Jr., I690-I734. member Provincial Assembly I729; associated with his father in manufacture of iron: married Mary Katherine, daughter Caesar Gheslin. a Huguenot. Great great grandson Thomas Rutter 3d, I/3I-I795, who married Martha Potts, daughter John Potts, I I IO-I 58 , iron-master: Justice of Peace, Berks Co., I745-49-52; Magistrate Phila. Co., I757; founder of Pottstown, $\mathrm{Pa}$. Thomas Rutter $3 \mathrm{~d}$. with his brother-in-law operated Warwick Furnace and engaged in casting heary cannon for the Colonial Government.

Eighth in descent from Edmund Hobart, I574-1646, founder of the town of Hingham, Mass., I635. formerly of County Norfolk, England; of the same family as the Earls of Buckinghamshire. He was Justice of Peace and representative in the General Court I639-40-4I-12.

Seventh in descent from Ret. Peter Hobart. I604-I6-9. B. A. Univ. of Cambridge I626. MI. A. I629, Ordained in Ch. of Eng. 1627. Became identified with Puritans: pastor Firs: Church, Hingham, Mass. 1635-79.

Great, great, great, great grandson of James Clarpoole, I634-I687, and his wife, Helena Merces. James Claypoole was son of John and Mary (Angell) Claypoole. and grandson of Adam Claypoole of Norborongh. Eng.. who married Dorothy. daughter of Robert Mingfield, of Upton and his wife Elizabeth Cecil, sister of Tilliam Cecil. Lord Burleigh, Prime Minister under Queen Elizabeth. James Claypoole was a friend of Trilliam Penn and came to Pennstrinania in 1683 ; became successively Justice of Peace. Member of the Assembly, Member of the Gorernor's Council and Register General of the Province.

Also great, great. great grandson of the Rer. Tim. Smith. I727-I803 (son of Thomas Smith, of Aberdeen, Scotland, and Elizaheth, daughter of Alexander Duncan. Esq.. of Lundie). D. D. of Oxford and Aberdeen Universities, I 759 , and Trinity College, Dublin, I764; first Prorost of College and Academy of Philadelphia (now University of Pennsylvania), I753-79: Founder and first Prorost of Washington College. Chestertown, MId., I780-9I ; married Rebecca, daughter of Colonel, the 
Hon. William Moore. Justice Peace of Moore Hail, Chsster County, $\mathrm{Pa}$. I699-I, 82 : of French and Indian Wars and of Lady Williamina Wemyss. I $\mathrm{O}_{4}-\mathcal{E}_{4}$, of Fifeshire, Scotland. and Loch. Eden. Ann Arundel County, MId. daughter of Co'onel, the Hon. William Wemyss. killed at Battle of Preston. serving under the Cheralier St. George (Prince James Stuart) in Jacobite uprising in $\mathrm{I} / \mathrm{I} 5$, and of Lady Elizabeth Loch, and descended from the Earls of Temyss of Temyss Castle. Fifestire. Great. great grandson of Wm. Mocre Smith, Esq.. IT59-I\&2I. Commissioner under the Jay Treaty between the United States and Great Britain. ISo3-4. and his wife Anne. daughter of Captain Jacob Rudolph of Chester County, Pa., who served in the war of the Revolution. Great grandson of Major General Wm. Rudolph Smith, 178--1858, of Huntingdon, Pa., who served in the war of ISI2-I4, and his wife Elizd. daughter of Joseph Anthon: of Philadelphia, and granddaughter of Hon. Michael Hillegas, I $729-1$ So4, Provinci:il Treasurer of Pennsylvania, Continental and First Treasurer of the United States. and of Henrietta Boude, of Boude family of County of Essex, England. Also tenth in descent from Sir Francis Moore, Knt. Sergt.-at-Law. M. P.. temp. James I. and serenth in descent from Hon. Ichn Moore, I658-I/32, lineally descencled from the ancient families of Moore of Fawley, Berkshire. Enz.. and Cary, of Torr Abbey, Deronshire. Eng.. of the I th century, member of the Governor's Grand Council of South Carolina, and afterwards Crown Attorner, Attorney General, Registrar General. Collector of Custcms of Port of Phila.. of Prorince of Penna., who married Rebecca. daughter of Col. Daniel Axtell. Landgrave, of Province of South Carolina, and of Lady Rebekah (so styled) his wife.

IV. I. Rutter. Ir. born at Pottstown, Montgomery County, Penna., October I2th, I8 $/$ I. educated in the public schools of that place and Columbia. Pa., and at St. Stephen's College. Annandale. $\mathrm{X}$. Y. Upon learing college in 1805 entered the employ of a National Bank in Philadelphia. Six years late: resigned to accept position with a firm of public accountants. 
A communicant of the Protestant Episcopal Church and since I904 has served on the Vestry of St. Mary's Church, Hamilton Village, Philadelphia. A charter member and secretary of the Church Historical Society. Also member of the Church Club of Philadelphia, Historical Society of Pennsylvania, Historical Society of Berks County, Montgomery County Historical Society, City History Society of Philadelphia and Society of the War of 18I2. Residence, 525 South 4Ist St., Philadelphia.

Thomas Rutter married Rebekah Staples.

Thomas Rutter, Jr., married Mary Katherin Ghesiin.

Thomas Rutter, 3rd, married Martha Potts.

David Rutter married Mary Ann Potts.

Charles Rutter married Mary Ann Ives.

William Ives Rutter married Sarah May Hobart.

William Ives Rutter, Jr., born Pottstown, October I2, I87 I.

Thomas Potts married Martha Keurlis.

John Potts (founder Pottstown), married Ruth Savage. Martha Potts married Thomas Rutter, 3rd.

See Rutter Schedule.

Edmund Hobart married Margaret Dewey.

Rev. Peter Hobart married I627, wife's name not known. Joshua Hobart married widow of John Rainsford. John Hobart married "A Swedish Lady." Enoch Hobart married Hannah Pratt.

Robert Enoch Hobart married Sarah May Potts.

Robert Enoch Hobart, Jr., married Henrietta Williamina Smith.

Sarah May Hobart married William Ives Rutter. William Ives, Rutter, Jr., born October I2, I87i. 
Adam Claypoole married Dorothy Wingfield.

John Claypoole married Mary Angell.

James Claypoole married Helena Merces.

Joseph Claypoole married Rebecca Jennings.

Rebecca Claypoole married Henry Pratt.

Hannah Pratt married Enoch Hobart.

See Hobart Schedule.

Thomas Smith married Elizabeth Duncan, sister of Adiniral Adam Duncan, Lord Camperdown.

William Smith, D. D., married Rebecca Moore.

William Moore Smith, married Anne Rudolph.

William Rudolph Smith married Eliza Anthony.

Henrietta Williamina Smith married Robert Enoch Hobart, Ir.

See Hobart Schedule

Sir Francis Moore (I558-I62I), of Fawley, County Berks, married Ann Twitty, of Borham, County Essex.

William Moore, of Great Fawley, near Wantage, married Mrs. Blount.

Francis Moore married Mary Cary, of Torr Abbey, County Devon.

I-Ion. John Moore ( I658-I732), of South Carolina and Pennsylvania, married Lady Rebecca Axtell.

Hon. William Moore, of Moore Hall, Pennsylvania, married Jady Williamina Wemyss.

Rebecca Moore married William Smith, D. D.

See Smith Schedule.

Lieutenant-Colonel Daniel Axtell, Governor of Kilkenny, in Ireland, and Commander of the Guard of the High Court of Justice in Westminster Hall at the trial of King Charles I.

Daniel Axtell, his son, married Lady Rebecca Holland.

I.ady Rehecca Axtell married Hon. John Moore.

See Moore Schedule. 
Michael Hillegas, First Treasurer of United States, married Henrietta Boude, daughter of Samuel and Deborah (Cox) Boude.

Henrietta Hillegas married Joseph Anthony.

Eliza Anthony married William Rudolph Smith.

See Smith Schedule.

\section{SCHINDEL.}

Samtel John Bayard Schindel, Captain, General Staff Corps, U. S. A., son of Captain Jeremiah P. Schindel, I839-94, 6th United States Infantry, married Martha Pintard, daughter of Samuel John Bayard and Jane Anne Winder Dashiell, of Baltimore, Md. Samuel John Bayard was the son of Samuel Bayard and Martha Pintard, and the latter was son of Colonel John Bayard, of Philadelphia, Pa., later of New Jersey, and Margaret Hodge of Philadelphia, Pa., son of James Bayard and Mary Asheton, and James Bayard was son of Samuel Bayard, born New Amsterdam I675; died Bohemia Manor, Md., Nov. 23, I72I, who married Ist, Susannah Bouchelle and 2nd, Elizabeth Sluyter. Samuel Bayard was the son of Petrus Bayard, son of Samuel Bayard and Ann Stuyvesant. Petrus Bayard married Blandina, daughter of Surgeon Hans Kierstede. Colonel John Bayard held many important positions during Revolutionary days. Colonel Second Battalion Cavalry, Pennsylvania Line. Member of Committee of Safety, I775-I777, Delegate to Provincial Congress. The Bayards went to New Amsterdam as early as I647 with their m-ather, and trace to the ancient family of Bayard of France.

Petrus Bayard was Deacon of Dutch Church, New York, Alderman of City of New Amsterdam, and with others had a large tract of land in Bohemia Manor, Maryland, and was one 
of the founders of a colony there. Colonel Bayard and others had a large tract of land in New Jersey. The Bayards descend from Rer. Nicholas Bayard of the University of Paris, who fled from Rochelle to Holland after the Revocation of the Edict of Nantes. Cadet of the House of Bayard of Picardie. In researches made by Gen. James Grant Wilson while on a risit abroad he found one of the ancestors of the Bayards in the records by the name of Nicholas Bayard, an eminent clergyman in charge of the French church in Antwerpt in I592.-.1. Y. Historical and Genealogical Magaine.

The Schindel family went to Pennsylvania from Germany in 1750 .

Captain Jeremiah P. Schindel was son of Rer. Jeremiah Schindel, ISo7-70, Chaplain in Mexican War, I8 $45-47$, and of I roth Regiment. Pennsylvania Tolunteers, in Civil War; son of Rev. John Peter, I787-I853, in War of I8I2; son of Johann Peter, I766-I829, of Lebanon, Pa.: son Johann Peter, I73284. from Erlebach, Province of ErBach, Germany. I750, settled at Lebanon, $\mathrm{Pa}$; son of Johann C., I685-I752; son of Conrad ron Schindel, I6/8, of Gemmelsback. Odenwald, Germany.

Captain Schindel was born at Camden, N. J., June 3, I87 r ; graduated United States Military Acadeny, West Point, June. 1893; 3rd Artillery, I893-I895: 6th Infantry, I895-1912, serving in Spanish-American VTar, battle of San Juan and siege of Santiago, Philippine Insurrection, and in campaign against hostile Noros: Bud Dajo, Mar. 5-9, I906, and west of Lake Lanao, May, I9II, September, i9i I. General Staff Corp Sept. 2, I9I2. Graduated Army War College, I907-08. He married Isa Gartery Urquhart Glenn, daughter of Thomas Join Glenn, I844-99, of Atlanta, Georgia, and Helen Augusta Garrard, and had issue.

Issue: ( I) S. J. Bayard, Jr., born Dec. 25, 1904, died in infancy: (2) John Bayard, born Sept. 4. 1907.

Arms: Gules, three shingles set in form of a triangle.

Crest: Out of a crown or, three shingles as in Arms, witliin a wreath rert between two wings gules.

Societies: Society of Santiago, National Geographical, Order of Washington. 
Clubs: Army and Navy, Manila, Army and Navy, Washington.

The following is taken from "Natthews American Armory and Blue Book," which shows the descent as given by Garrard Glenn, brother of Mrs. Schindel:

"Glenn Garrard, of New York (son of John Thomas Glenn, I844-99, of Atlanta, Georgia, lawyer, married April 23, I873, Helen Augusta, daughter of William Waters Garrard, of Hilton, Georgia [6th in descent from Peter Garrard, of Lille, France, who settled in England 1687]; son of Luther Judson Glenn, I8I8-86; son of Thomas, I783-I830; son of Duke; son of Thomas; son of Dr. John Glen, of North Carolina; son of Alexander Glen, of 'Longcroft,' Linlithgow, Scutland. Mr. Glenn is descended on the paternal side from Thos. Reade Rootes, of Whitemarsh, Va.; Colonel George Readc, who came to Virginia 1637 ; General Robt. I.ewis, who came to Virginia 1635 , son of Sir Edward Lewis, Knighted by James I., I603; also, on the maternal side, from Major James MacGregor, who fled to Virginia when his clan was proscribed, died I724, a descendant of King Robert II. of Scotland). Born at Atlanta, Georgia, August 7, 1878; lawyer. Arms-Argent, a fesse gules between three martlets sable. Crest-A martlet sable. Motto-Ad Astra. Residence--New York City."

In records of North Carolina the follownig Glenns are found :

John, Warham, Duke, George, James, Tobias and Wm. Glen.

In the will of Duke Glenn, made November 14, I788, Greene County, State of Georgia, we abstract the following:

"I, Duke Glenn, planter, etc., lands lying in the State of North Carolina, Pee Dee River. My son David Glenn, plantation, Washington County, beloved wife, Ann Glenn; daughter, Lucy Glenn.

Exx. and appoint beloved wife, Ann Glenn, and my sons, David and John Glenn.

Witnesses,

WiLliam Foster,

Duke Gleinn, John Bush. 


\section{SHEPHERD.}

R. D. Shepherd was born in New Orleans, Louisiana, Narch 7,1859 , and is the son of Henry Shepherd and Azenia McLean. He attended college at the University of Virginia and also Washington and Lee.

Under the stage name of R. D. McLean he has achieved a splendid reputation as an actor of tragedy and is now one of the principal actors in America.

He has personified the following characters in the different plays upon the stage: Nacbeth, Brutus, Othello, Shylock, Richard III, King Iohn, Coriolanus, Ingomar, Virginius, Mercutio, Romen, Orlando, Jacques, Leontes Brutus-as Brutus in the fall of Tarquin-and many others.

Henry Shepherd was the son of Henry Shepherd, born January 6, I793, and Fanny Briscoe, and the above Henry Shepherd was the son of Captain Abraham Shepherd, who commanded a company of the Continental line in Colonel Hugh Stevenson's Regiment.

Captain Abraham Shepherd married, December 27, I780, Eleanor Strode, born January 27, I760, daughter of James Strode, a Justice of Berkley, who married Ann Forman. Captain Abraham Shepherd was the son of Captain Thomas Shepherd, founder of the town of Shepherdstown, Jefferson County, West Virginia, formerly called Necklenburg. Captain Shepherd owned the land and the town was named for him.

Captain Thomas Shepherd, Founder of Shepherdstown, died 1776. Left will. Married Elizabeth Van Meter, died 1739. Left will. Daughter of John Van Meter. the earliest settler. Their son

Captain Abraham Shepherd, member of Hugh Stevenson's Company, Revolutionary War, and had fine war record; born 1754, died 1822; married Eleanor Strode, born 1760 , died 1853. She was a daughter of Captain James Strode, of Berkeley County, Virginia: he was a Justice of Berkeley County. 1772. Their son

Henry Shepherd, born 1793, died 1870; married Tannie Briscoe. Their son

Henry Shepherd, born 1831, died 1891; married Azenia McLean of New Orleans. Their son was

Rezin Davis Shepherd.

Thomas Shepherd, the founder of Shepherdstown, must hare rotten his designation as Captain from services in the French and Indian Wars. There was always a "Home Guard" in those frontier 
towns such as Shepherdstown. The Virginia Colonial Goversment at Williamsburg, Va., took very little care of its western border settlers and so they took good care of themselves. Henning's Statutes at Large record the granting of permission to incorporate Shepherdstown by Thomas Shepherd.

John Van Meter had a daughter, Elizabeth, who married Captain Ihomas Shepherd. He was in Virginia, 1732. See Vol. III W. Virginia Historical Magazine. The ancestor of Thomas Shepherd appears to have been another Thomas or Henry of New Jersey. The Van Meters had large tracts of land and the Shepherds had several tracts.-J. G. B. B.

See Van Meter and Shepherd families.

R. D. Shepherd married on April I, I897, at New York. Elizabeth Lee Kirkland, known on the stage as "Odette Tyler" a lady who, as an actress and an author of plays, has acquired a position of considerable prominence in the theatrical world. She is the daughter of Brigadier General W. W. Kirkland, C. S. A., a gallant confederate who comes of the old family of Kirkland of North Carolina, of which family was Sir Jno. Kirkland, one of the line who went to England to live and who was Knighted.

General Kirkland married Susan Ann Hardee, daughter of Noble Andrew Hardee, an eminent merchant of Savannah, Ga., who had also studied law and whose brother was I.t. Gen'l Wm. J. Hardee, formerly Commandant at West Point, author of "Hardee's Tactics" and a prominent General in the war between the States. His cousin was Admiral Kirkland, U. S. Navy.

Noble A. Hardee was the son of Major John Hardee and Miss Ellis. The name of Hardee occurs as far back as May 3I, I738, in the Records of North Carolina. The family removed apparently to South Carolina, but a branch removed to Georgia and we find Captain Hardy who commanded a galley or vessel of war during the Revolutionary War.

Noble A. Hardee married Margaret Lewis, daughter of John Lewis and Susan Adams, son of Joseph Lewis and Susannah Baker, son of Isaac Lewis and Susan Kirkland, son of Samuel Lewis and Mary.

There is a tradition that the Lewis family of Georgia were descended from the Washington family, and this is probably 
true, as there has been found in the records of Westmoreland County, Va., the will of a Lawrence Washington, in which he speaks of his sister Lewis, and as eariy as I 7 I w we find John Lewis. John Smith and Jno. Washington, Jr. applying for land in Westmoreland County. Ta. The Lewis's of Georgia are said to have come from Virginia. They evidently went to North Carolina, thence to South Carolina and Georgia, in the latter State occupying different positions in the military and civil life of the Colony and State.

Susan Adams was the daughter of Nathaniel Adams and Anne Bolton, both ancient families whose records can be seen in the sketches of Bulloch and McBryde.

From Washington Post, May I3, I9I 5.

$$
\text { GEN. W. W. KIRKLAND DEAD. }
$$

Funeral of Brillant Confederate Officer Will Take, PLACE TOMORROW.

Gen. W. W. Kirkland, one of the most distinguished officers of the Scuthern Confederacy, died at the residence of his son-in-law, R. D. Shepherd, 1925 Biltmore street, yesterday morning. He was born in Hillsboro, N. C., in I833, and was the son of John W. Kirkland and Elizabeth Simpson. He went to West Point in 1852 , and later resigned to enter the United States marine corps. When the civil war began he entered the service of the Confederate States and became aid to Gen. William Hardee, whe was the uncle of his wife, Susan A. Hardee.

Owing to his valuable services he was made a brigadier general, having been a member of the Twenty-first North Carolina regiment, being one of the youngest in the service at the time of his promotion. He especially distinguished himself by bravery at the battle of Winchester.

Gen. Kirkland will be buried tomorrow morning at Shepherdstown, W. Va., the summer home of his daughter. He leaves two children, Mrs. Elizabeth Lee Shepherd and Noble Hardee Kirkiand. 


\section{SMITH.}

Sidney Fuller Smith in Melrose, Mass., on the 28 th of October, 1863. He was the son of Simeon B. Smith and Nary Jane Fuller, daughter of Zenas Fuller and Mary Stevens; son of Edward Fuller of Leonminster, Mass., and Nancy (Anna) Thurston; son of Edward Fuller and Lucy Hubbard; son of Edward Fuller and Sarah Quarles, of Ipswich, Mass.; son of Jacob Fuller, who on June 19, if $\&_{3}$ married Mary Bacon; son of Thomas Fuller, of Woburn, anci Eliza Tidd.

Edward Fuller of Leominster, Mass., served as a private at Boston and later at Bennington.

His ancestor, Thomas Fuller, of Wales, went to Massachusetts in 1638 and died in I698. He settled in Salem and was often town officer.

\section{STEIVART.}

J. McDonald Stewart, son of James M. and Susan A. Swett, born in Alexandria, Virginia, educated in the private schools of Alexandria, Military Academy, Trenton, New Jersey, and a year's course at the Columbian College, Washington, D. C. ; entered the Treasury Department in 1874, and the Pension Bureau in 1879 , serving to date as clerk, examiner, and special examiner.

His great grandfather, John Stewart, came to Virginia about I750, from Scotland; his son, Robert, moved to Alexandria, Virginia, in I8I2, and two years later while serving with General Gerry, D. C. Militia, War of I8I2, was killed. James M. Stewart lived in Alexandria nearly 70 years and carried on a mercantile business. 
McDonald Stewart traces his Colonial and Revolutionary ancestry to Nathaniel Clarke, born in Newbury, Mass., I644. He was a Selectman, naval officer of the ports of Newbury and Amesbury, Mass., Ensign of Captain Pierce's company, and owned considerable property for those days. The genealogical history of the Clarke family with all data is on file in Newburyport, Mass. His direct descendant, Greenleaf Clarke, was first and second lieutenant and captain, during the War of the Revolution, serving from June, I777, to September, I778. He commanded a company at the Battle of Bunker Hill; he married Eleanor White, October I, I772, and his daughter Rebecca married Captain Samuel Swett, December 27, 1779. He was a large ship-owner at Newburyport, Mass., his daughter, Susan A. Swett, born in Newburyport, April I2, I8I7, married James M. Stewart, who was born i. Front Royal, Virginia, October 23, I8I I.

Greenleaf Clarke and his widow, Eleanor, were both pensioners of the United States, File No. I4,494, and Certificate No. 2521, Pension Bureau; also, roster of Massachuset!s Soldiers and Sailors of the Revolution, Vol. 3, page 529, on file in the Pension Bureau.

\section{STILLMAN.}

Thomas B. Stillman, Chemical Engineer; born Plainfield, N. J., May 24 th, $18_{52}$, is the son of Dr. Chas. H. Stillman, born January 25th, I8I7, and Mary E. Starr, born September 7 th, I82I, of Schenectady, N. Y., son of Joseph Stillman of Newport, R. I., born January I4th, I779, and Elizabeth Ward Maxson, born September I Ith, I783, daughter of Caleb Maxson of Newport, R. I., born November 2nd, I752, and Mary Bliss, born May, I757; daughter of Elder William Bliss, born 
February, 1728, and Barbarra Phillips, born August 6th, I727; son of Josiah Bliss, born March 6th, I685, and Mary Belcher: son of John Bliss, born August Ist, I645, and Damaris Arnold, born February 23rd, I648, daughter of Governor B. Arnold, born December 21st, 1615, and Damaris Wescott. Governor Arnold was Governor of R. I., I663, 64, 65, 66, 69, 70, 71, 72, 77,79 .

Through the Starr line, descendant of Elder Wm. Brewster of the Mayflower through the Lanphear* line, descendant of Joseph Clark ( I648), one of the parties to whom the charter of R. I. was granted by King Charles the Second.

B. S., Rutgers Coll., I873, M. Sc., I876; Ph. D., Stevens Institute Tech, I883; graduated Fresenius Lab., Weisbaden, Germany, I877; married Emma Louise Pomplitz of Baltimore, November 3rd, 188I. Institute analyt. chemistry. I874-6 and I88I-6; Professor analyt. chemistry, I886-I903; Professor Engineering Chemistry, 1903-9, Stevens Institute Tech; retired upon Carnegie Pension Fund, 1909. Appointed State inspector of oils, New Jersey, I884; examiner in Chemistry Municipal Civil Service, New York, I9II; City Chemist Jersey City and Bayonne, N. J. Member American Chemical Society, Society Chemical Industry (London), American Institute Mining Engineers, International Association for Testing Materials, American Electrochem Society, Societe Chimique de Paris, Phi Beta Kappa; corresponding member Edinburgh Society Arts \& Sciences, Deutche Chemische Gesellschaft; member S. R., New York Chapter, Society Mayflower Descendants. Editor Stevens Institute Indicator, I895. Author Engineering Chemistry, I897, I901, 1905, I910. Has written many monographs and papers in Almerican, English, French, Italian and German chemistry journals on investigations in technical and applied chemistry.

*Betsey Lanphear, born February 1, 1799, was a grandmother of Mary E. Starr, born September 7, 1821. 


\section{STOCKTON.}

Charles Herbert Stockton, Rear Admiral U. S. N.; born at Philarlelphia, October I3, I845; son of Rev. Wm. R. and Emma T. Stockton; appointed to U. S. Naval Academy from Pennsylvania, 186I, graduated I865; (ILL. D., George Washington University, I909); married Pauline Lentilhon King, of New York, November 23, I880. Ensign December I, I866: master, March I2, I868; lientenant, March 26, I869; lieutenantcommander, November I5, I88I ; commander, April 3, I892 ; captain, July 8, I899; rear-admiral, January 7, I906. Summer of I864 on board the Macedonian, in pursuit of the Confederate steamers Florida and Tallahassee; served on Dacotah, Chattanooga, and Mohican, going to the North Pacific by way of the Strait of Magellan, in Mohican; Pacific Squadron, I855-9; Nary Yard, Philadelphia, I869-70; I873, I874; Congress and Brooklyn, I870-3; Dictator, I873; Swatara, I874-5; Hydrographic Office, I875-6; Plymouth, I876-9; Navy Yard, New York, I879-80; Nary Yard, Washington, I880-82 ; Iroquois, I882-5; Bureau of Yards and Docks, I885-9; commander Thetis, I880-9I, cruising in the Arctic Ocean; Naval War College, I89I-94; special duty, I894-5; commander Yorktown, I895-7; President Naval War College, I898-I900; commander Kentucky, I90I-3; naval attache, American Embassy, London, I903-5; President Board Inspection and Survey, I906; President Naval Examining and Retiring Boards, I9o6-7; commanding Special Service Squadron, visiting Bordeaux, France, for the maritime experience, I907 ; retired, October I3, I907 ; President George Washington University, I9I I. First United States delegate to London Naval Conference, IgoS-9. Author of United States Naval War Code, and a manual of international law; has written several articles and papers upon that and other subjects. Home: 2019 O Street, N. W., Washington.

Admiral Stockton is a scion of the well-known New Jersey family of that name, a family that has been prominent in America continuously for nearly three hundred years. The 
beginning of the family in the United States was the settlement of Richard Stockton, an Englishman, in Flushing, Long Island, in I660. He was appointed a Lieutenant of Horse in Flushing under the King in I665. From him the New Jersey Stocktons are descended, Richard Stockton going in a few years to Burlington and his eldest son to Princeton. Admiral Stockton is seventh in direct line from Richard Stockton and belongs to the Burlington County branch of the family. The Princeton branch has furnished a signer of the Declaration, a Commodore, and two U. S. Senators, etc., etc. The Burlington County branch contained the Rev. William H. Stocktor, Chaplain of both Houses of Congress, and Frank R. Stocktor, a distinguished novelist.

\section{TALBOT.}

Archie Lee Talbot, Vice-Deputy Commander for Maine. was born September I4, I846, in Phillips, Maine, son of Charles Johnson Talbot, late of Wilton, Maine, and his wife, Delphinia Shaw Robbins, daughter of Asa Robbins, Jr., and his wife, Hannah Shaw. Hon. Charles J. Talbot was a lawyer and farmer; a conspicuous leader in the formation of the Republican party, in 1854 , and the War Vice-President Hannibal Hamlin's life-long close friend and adviser. (See Life and Times of Hannibal Hamlin, by E. C. Hamlin, I899; pp. 235,446 .)

Mr. Talbot traces his ancestry, in the male line, from Le Sire Talebot, the Norman Knight who came into England, A. D. I066, with William the Conqueror. (See "Lineage of the Talbot Family," I9I4, by Archie Lee Talbot.) He comes from 
both Puritan and Pilgrim stock of New England. The first of his family in America was Roger Talbot, of Boston, Massachusetts. He was the second officer (First Mate) of the armed Sloop George, in the Nary of the Province of Massachusetts Bay, in the Abenaki War in I722-3, and acting Captain, after the Captain had been mortally wounded by the Indians, when transporting troops and supplies to forts un the coast of Maine. His great, great grandfather, Ambrose ${ }^{2}$ Talbot, son of Roger ${ }^{1}$, was a veteran of the French and Indian Wars, and a soldier of the American Revolution, serving one month (September 23 to October 23, 1779) in Captain George Rogers ' Company, Colonel Nathaniel Jordan's Regiment, in the coast defense of Falmouth (Portland, Naine), on an Alarm that Mowatt, who bombarded and burned the town in October. I755, was cruising near Falmouth with three British war ressels.

The first of his mother's family in America was William Robbins, who first appears in the records of New Engiand during King Philip's War, I6 $55-76$, with men from Reading. and several other parts of the Province of Massachusetts Bay. in service against the Narragansett. and treacherous Nipmuck Indians, for which he, with others, was granted, by the General Court, a township of land eight miles square.

His mother's grandfather. Asa Robbins, of Walpole, Mass., was a soldier of the American Revolution, serving five months in I776, in Colonel Samuel Brewer's First Regiment of Massachusetts troops at Ticonderoga, and, at the age of serenteen years, with rank of Corporal, in 1778. in Colonel Samusl Brewter's Twelfth Regiment in the Massachusetts line, in Washington's Army in New York. His mother's father, Asa Robbins, Jr., of Winthrop, Maine, at the age of twenty-three years, served with rank of Corporal in Captain Samuel Randlett's Company of Artillery in Major Joseph Chandler's Battalion in the coast defense of Maine, in the War of I8I2.

His mother's maternal grandfather. Captain Abraham Shaw. of Middleboro, Massachusetts, marched with his Company on the Alarm of April 19, I775. and was Sergeant in Captain 
Isaac Wood's Company, from Middleboro, in Colonel Theophilus Cotton's Regiment, in the Battle of Bunker Hill; his mother's maternal great grandfather, Lieutenant John Miller, 3rd, of Milldeboro, was a Private in Captain Benjamin Pratt's Company, Colonel Thomas Doty's Regiment, in the expedition to Canada, from April 2 to December 29, I758, and Lieutenant of the Sixth Company of Militia (Plymouth County), Colonel Ebenezer Sproutt's Regiment, in active service in the War of the American Revolution, and on June 3, I784, he was commissioned Captain.

Mr. Talbot is also, on the maternal side, a lineal descendant of six of the Pilgrims of the Mayflower, two of whom, John Howland and John Tilley, signers of the compact, were in. the "First Encounter," with the Indians, I620.

Archie Lee Talbot had the advantages of the town and high schools and Maine Wesleyan Seminary, Kent's Hill, Maine. class of '67. He was clerk in his father's law office, and Depuly Collector of U. S. Internal Revenue for Maine, under the administrations of Presidents Grant and Hayes. On January I3. I869, he was united in marriage with Nina Victoria Adams, of Georgetown, Massachusetts, who was a former schoolmate in East Wilton, Maine, a lineal descendant of Philip Adams, of Georgeana (York), in the Province of Maine, who toois the oath of a freeman in 1652 . Mrs. Talbot is prominently connected with fraternal and literary societies in Maine, hav ing been President of the Woman's Literary Union, of Woman's Clubs, in Androscoggin County, and Grand Matron cf the Grand Chapter of the Order of the Eastern Star, of the State of Maine. They have three sons who are active business men. In 1877 he removed from Wilton to Lewiston, which has since been his home. On retiring from the revenue service, he engaged in Fire and Life Insurance, and for fifteen years was General Agent for Maine, for the Provident Life and Trust Company, of Philadelphia, Pa. He was Aldermain for two terms; for ten consecutive years he was a member of the Liswiston School Board, and has represented Lewiston in the Legislature of Maine. Without going into details, it may 
be said that Mr. Talbot is a Permanent (Life) Member of all the Masonic Grand Bodies in Maine; Chairman, and for twenty-five years a member of important committees in the Masonic Grand Bodies.

He takes special interest in the patriotic hereditary societies as, in his view, no better way could be devised to preserve the records and the sacred memory of the founders and preservers of our country.

In $\mathrm{I} 893$ he was elected a member of the Society of the Sons of the American Revolution, when the society was young. In I898-9 he was President of the Maine Society, and did much for the success of the society in Maine. He was a delegate from the Maine Society, to the Congress of the National Society S. A. R., in Boston, Mass., in I895; to the Congress in Richmond, Virginia, in 1896 ; to the Congress in Morristown, N. J., in I8g8, and to the Congress in New Haven, in 1903. In the Congress at Morristown, he was successful in his efforts to have the color buff (officer's color) added to the colors of the society, making same "blue, white and buff."

In 1897 he was elected a member of the Massachusetts Society of Mayflower Descendants, and was the founder of the Maine Society. The Charter of the Maine Society is dated September 6, I90I, and his name is the first of twenty charter members. He is a Past Governor of the Maine Society, and at present Deputy Governor General, elected at the Triennial Congress, at Plymouth, Mass., in 1906, re-elected in 1909, and again in 1912.

In January, I9I I, he was elected a member of the Society of American Wars, Commandery of the State of New York, and is the founder of the "Commandery of the State of Maine of the Society of American Wars of the United States of America." The Charter is dated February I4, I9I2, and his name is the first of the twenty charter members. He is the first Commander and one of the Vice-Commander Generals, having been elected by the Commandery-in-Chief, in Washington, D. C., in January, I9I3, and re-elected in I9I4. 
He is also a member of the Maine Society of Colonial Wars, and the Massachusetts Society of the War of I8I2.

Mr. Talbot is a member of the Maine Historical Society, the oldest Society in Maine, but one, (the Grand Lodge of Ancient, Free and Accepted Masons), having been incorporated, by the Legislature of Maine, in 1822 . He is a writer of historical articles for magazines and for the press.

In March, I9I2, he was elected a Companion of the Order of Washington, which Order he prizes highly. In February, I9I4, his three sons, William Wiggin Talbot, Carlton Baker Talbot, and Ralph Lee Talbot, became hereditary Companions of the Order.

\section{THOMSON.}

Dr. Lewis B. Thomson, son of the late Rev. George Washington and Elizabeth Brainerd Thomson, received his early education in the public schools of Syracuse, N. Y., and the Onondaga Academy, same State, graduating with the degree of M. D. from the Maryland Medical College, Baltimore. He practiced his profession in Silver Springs, Md., until several years ago, when he removed to Mount Pleasant, D. C.. since which time his energies have been chiefly devoted in assisting to maintain the only emergency hospital in that new portion of Washington. He is now and has been for some time, its day physician. His home is on the Arenue of the Presidents, near the bridge.

Dr. Thomson acquired his membership in our order by reason of his ancestor. Hezekiah Brainerd, who had been three times 
chosen as Speaker of the Provincial House of Delegates, Connecticut. His great grandfather, Josiah Brainerd, at the age of sixty-five, enlisted as an ensign in Wadsworth's Brigade, 4th Connecticut Battalion, of the Continental Army. Three great grandparents from State, Jonathan Cutler, Ase Huntington and Nathan Thomson, also took part as soldiers of the American Revolution.

His ancestor, Daniel Brainerd, was a Justice of the Peace, and one of the founders of the town of Haddam, Connecticut.

Dr. Thomson is a member of the Washington Medical Society, the District of Columbia Society Sons of the American Revolution, the Mount Pleasant lodge of Free and Accepted Masons, and the Central Presbyterian Church there. In I887 he married Niss Anna Merriman Ray, daughter of the late Mr. Alfred Ray, a prominent and progressive agriculturalist of Montgomery County, Maryland. Her ancestor, Charles Merriman, held an appointment of Captain in the Colonial Army, and his grandson, Benjamin Merriman, was a Captain in a Maryland regiment in the Revolutionary War.

Dr. Thomson's son, Alfred Ray Thomson, is now, and has been for several years, a Deputy Consul General of the United States, to Berlin, Germany.

\section{TURNER.}

Dr. Francis Muir Turner, of Savannah, Ga., was born in New Orleans, La., on January 8, I884, and is descended from a long line of well known ancestry. His ancestor, Richard Turner, had a grant of the Island of Whitemarsh, near Savan- 
nah, Ga. Among other of his ancestors may be enumerated Captain John Barnard, of the King's Rangers in Georgia, who married the daughter of Wm. Bradley, gentleman. He also descends from the ancient families of Newell, Bolton, Curtis, Adams, Bryan and Colonel Richard Wylly, of the Revoluticn, and others.

Dr. Francis Muir Turner is the son of Lewis Tattnall Turner and Mary Wylly Newell and grandson of Commodore Thomas Newell and Hester R. Adams, great grandson of Thomas Newell and Rebecca Bolton and great, great grandson of Robert Bolton, of Savannah, Ga., and Susannah Mauve and great, great, great grandson of Robert Bolton, Sr., and Ann Clay, nee Curtis, granddaughter of John Curtis, member of Penns Council, Kent County, Delaware.

Robert Bolton, of Savannah, Ga., held many positions in Colonial days: Collector of 'Taxes Christ Church parish, Savannah, Ga.; Armourer; Commissioner of the Work House, I754: first Postmaster in Georgia, I764. He had a grant of land of 500 acres in St. Paul's Parish, August 27, I774, and on May 4, 1778 , was one of the enquirers and assessors of taxes for the town of Savannah and espoused the cause of colonies against the mother country. He went to Georgia about I74I-2. He was the son of Robert Bolton, Sr., Junior Warden Christ Church Parish, Philadelphia, Pa.; Senior Warden I727; Vestryman I726. Robert Bolton, Sr., married Ann Clay, widor, daughter of Winlock Curtis, son of Hon. John Curtis, of Kent County, Delaware, a member of Penns Council.

TYLER.

Dr. Lyon Gardiner Tyler, President William and Mary College since I888; born Charles City, Ta., I853, son of John Tyler, Ioth President of U. S. ; by his second wife Julia Gardiner, son of John Tyler, Captain Virginia Militia; mem- 
ber Virginia House of Delegates, and Mary Armistead, son of John Tyler and Anne Comtesse, son of John Tyler and Elizabeth $I_{1}$. Jarrett, son of Henry Tyler and Elizabeth Chiles, son of Henry Tyler and Anne Virginia I875: M. A. same; LL. D., Trinity College Conn., 1905. Became, in January, I877, professor belles lettres, Wiiliam and Mary College; principal of a high school in Memphis Tenn., I878-I882; practiced law in Richmond, Va., I882-8; member of the House of Delegates, Va., I887; married, November I4, I878. Annie B., daughter of Colonel St. Georgz Tucker, of Tirginia. Author of The Letters and Times of tine Tylers; Parties and Patronage in the United States; Cradle of the Republic, I900; also The Contribution of William and Nary to the Making of the Union, and other addresses and pamphlets; editor and proprietor William and Mary College Quarterly Historical Magazine, founded in I892; editor of Narratives of Early Virginia, I606-I625; member State Board of Education since I903. Address: Williamsburg, Va. Tice Deputy Commander of the Order of Washington for the State of Virginia.

\section{VAUGHAN.}

George Tully Vaughan, born at Arrington, Nelson County, Va., June 27, I859, son of Dr. W. L. and Frances Shields Vaughan, is of Welsh descent, according to a legend which has long existed in the family. Walter Vaughan or his son settled in Virginia soon after Jamestown was settled. The written family record goes back to I700 when John Vaughan was living in King George County, Va. Another ancestor 
was Giles or George Brent, who came to St. Mary's Colony, Md., with Calvert in I637. Another was James Nevil, a captain, probably in Indian wars, whose will was probated in Albemarle County, Va., in I740. His son, James Nevil, born I728, died I784, was a captain of a company of Albemarle County militia during the French and Indian War, I757 and 1758 (see Hening's Statutes, Vol. VII, pp. I7I-202), and later during the Revolution was colonel of the Amherst County, Va., troops.

The subject of this sketch was educated at private schools, and at the University of Virginia, from which he was graduated M. D., in I879; and in I880 was graduated from Bellevue Hospital Medical College, N. Y., with the same degree. Later he studied in Europe, especially at the University of Berlin.

He was in the United States Marine Hospital Service I8 years, and was assistant surgeon general in that service when he resigned in order to give his entire time to surgery. During the war with Spain he served as Brigade Surgeon in the Seventh Army Corps, commanded by Fitzhugh Lee. During the American occupation at Vera Cruz, Mexico, he served as chief operating surgeon of the First Marine Brigade, U. S. Navy. He has filled the position of professor and head of the surgical department in Georgetown University, since 1897; is chief surgeon to Georgetown University Hospital; surgeon to other hospitals; member of numerous surgical and patriotic societies, such as Colonial Wars, Cincinnati, etc., and is the author of a book on surgery, and numerous papers on surgery.

VAN VOAST.

Horace Silliman Van Voast, son of Albert and Mary 
(Vedder) Van Voast, was born in Niskayuna. Schenectady County, N. Y., on September 23rd., I869. He was educated in the public schools and Union College of Schenectady, N. Y., leaving the latter institution in his sophomore year ( I889) to enter business life in Cohoes, N. Y. He remained in Cohoes until the fall of 1897 , when he returned to Schenectady, N. Y.; since which time he has been engaged in the insurance business in the latter place. In I900 he was elected Recorder of the City of Schenectady on the Republican ticket, which office he resigned in I90I and was elected Mayor of the City of Schenectady, serving as such in I902-3. He was again elected Mayor in 1907 , serving in 1908-9.

He was married June 9th, I893, in Newark, N. J., to Mary Wakeman Salter (born in Brooklyn, N. Y., January i6th, I873), daughter of Walter Wakeman and Emily (Lockwood) Salter; they have the following children: Marjorie Lockwood, born January 5th, I896; Frances Elizabeth, born November I5th, I807; Horace Silliman, born February 8th, I90I.

Through his ancestors (all of Dutch descent) he enjoys membership in the following historical and genealogical orders and societies: The Holland Society, Sons of the Revolution, Sons of the American Revolution, Society of Colonial Wars, Order of the Founders and Patriots of America and the Order of Washington; he is also a member of the New York State Historical Association and the Schenectady County Historical Society.

The Van Voast line of descent from Gerrit Janszen Van Vorst (first American ancestor) is as follows :-

I. Gerrit Janszen Van Vorst, born in Holland in 1618, married Creertryud___ ; he came to New Netherland prior to I640, and was killed by an Indian in 1642 (see de Vries "Journal," pages 152-3). He left two sons, Jan Gerritsen Van Vorst, born —_ and Jacobus Gerritsen Van Vorst, baptized July 3rd, I642.

2. Jacobus Gerritson, son of Gerrit Janszen Van Vorst, seems to have been without paternal direction or guidance, his father having been killed the year of his birth; in 1662 the 
Records of New Amsterdam show him to be charged with "fighting and rioting by night at unseasonable hours"; in I668 he was living at New Utrecht on Long Island; in I67I he was living in Albany; about I 700 he removed to Schenectady and continued to reside there until his death, which occurred later than 1720 . It is not known where or to whom he was married. The records of Albany show that his son Jellis (then II years old) was in I68I apprenticed to Jeronimus Wendell to learn shommaking.

3. Jellis, son of Jacobus Gerritsen Van Vorst, was born in I670; lived in Albany until about I700, when he went io Schenectady; he married, on July I6th, I699, Elizabeth, daughter of Johannes Van Eps and widow of Teunis Viele. He was of the First Foot Company of Schenectady, Captain Johannes Sanderse Glen, commanding. Children, with dates of baptism:-Johannes, November 9th, I70 ; Jacobus, December I2th, I703; Dirck, August 25th, I705; Gerrit, May 26th, I708; Douw, February I5th, I7I0; Jan Baptist, October 2Ist, I7II; Sara, November I4th, I7I3; Elizabeth, February 4th, I7I6; Gysbert, January I7th, I72I.

4. Jacobus, son of Jellis Van Vorst, married Anna, daughter of Caleb Beck, February I4th, I728, in Albany, N. Y. Children with dates of baptism:-Margriet Vedder, September I8th, I726; Caleb-, I730; Anna, October 22nd, I732; Jellis, February 9th, I735; Engeltje, July 6th, I738; Johannes, born January I9th, I74I, baptized February 8th, I74I ; Abraham, April 3rd, I743; Jan Baptist, February 22nd, I746. 5. Johannes, son of Jacobus Van Vorst, married Sarah, daughter of Joachim Kittel, September IIth, I762. He died in Glenville, Schenectady Co., N. Y., on May 23rd, 1844 , in his IO4th year; his wife died February Ist, I834, aged 89 years, 9 months and 23 days. He was a soldier of the Revolution, First Regiment of the Line of N. Y., Col. Goose Van Schaick's Regiment. Children baptized:-Jacobus, May 23rd, I763; Joachim, July 28th, I765; Annetje, February I3th, I768; Caleb, October 24th, I770; Adam, September I9th, I773; Jellis, January !2th, I777; Johannes, November I2th, I780. 
6. Joachim, son of Johannes Van Vorst, married Neeltje, daughter of Albert Vedder, January I2th, I789; he died in Schenectady, Juiy I3th, I849, in his 85th year; his wife died Nay 30th, 1826 , in her 59th year. Children, with dates of birth:- Esther, January 24th, I792; John, November 4th, 1794; Alhert, December I6th, I797; Jacobus, November 4th, I80o. During his early life he changed the spelling of surname from Van Vorst to Van Voast.

7. Albert, son of Joachim Van Voast, niarried Maria Benson in I 826. She was the daughter of Garret and Maria (Van Vranken) Benson, and was born in Schenectady on April I5, I80o. Albert Van Voast died in Schenectady, August 26, I869; his wife died April 28, I873. Children born, Ellen I828, died - , I853; Benson, born —, I83I', died —_- I903; Albert, born April 22, I834.

8. Albert, son of Albert Van Voast, married Mary Vedder, June 6, I863; she was the daughter of Aaron and Elizabeth B. (Spaun) Vedder, and was born in Niskayuna, N. Y., on February I4, I844, and died in Schenectady on June I2, I908. Children with dates of birth: Albert Benson and Horace Silliman (twins), September 23, I869; Ellen Mary, June Io, I873.

\section{THE VEDDER LINE.}

I. Harmen Albertese Vedder, the founder and first settler was a trader in Beverwyck prior to 1657 ; in 1660 he returned to Holland; in I66I he was again in New Netherland, and brought suit against certain inhabitants of Gravesend; in I663 was in Schenectady; in I668 was in Holland and with other merchants from the Province of New York, chartered the ship "King Charles"; in 1673 he was appointed one of the 
Magistrates of Schenectady'; in 1674 he was Schout (Sheriff) of Schenectady. It is believed he died in I7I5. The following children were living at that time: Harmanus; Arent; Albert; Johannes; Corset; Angenietje. Two of his sons, Albert and Johannes, were carried away captives by the French and Indians, at the Schenectady Massacre, February 9, I690.

2. Arent, son of Harmen Albertese Vedder, married Sara, daughter of Symon Groot; he made his will in Niskayuna. August IO, I746; all his children were then living. Children baptized: Agnietje, February II, I694; Rebecca, October 25, I695; Harmen, May 28, I696; Maria, September I, I699; Susanna, July I3, I70 I ; Sara, January 30, I704; Simon, born October 3, I707; Lysbeth, October I9, I7II; Albert, bo:11 November IO, I7I4.

3. Simon, son of Arent Vedder, married Maria Truax, widow of Simon Groot, January 16, I735; he died in Niskayuna, May I7, I79I ; the date of his wife's death is not known. They had the following children: Arent Simon, born August I4, I735; Philip, baptized July 9, I737; Harmanus, March 4, I739; Neeltje, December 6, I74I : Sarah, May I3, I744; Annatje, September I4, I746; Maria, October I5, I749; Agnietje, April 5, I752; Susanna, May 18, I755; Anna, March I $2,175^{8}$.

4. Arent Simon, son of Simon Vedder, married Jannetje, daughter of Johannes Truex, on December Io, I768; she was born November 12, I744, died April IO, I780; he died in Niskayuna on November II, I8II; he was a soldier in the Revolution, serving as Lieutenant in Colonel Abraham Wemple's Regiment, of Albany County Militia. The following children were living at the time of his death: Simon Arent, born September I, I772; Maria, February 27, I775; Alida, September 12, I777.

5. Simon Arent, son of Arent Simon Vedder, married Mary Bassett. November 14, I807; she was born January 30, I782, and died January I7, I823; he died in Niskayuna, N. Y., December 22, I844. Children: Ann, born August 24, I808; Aaron, born December 27, I8o9: Michael Bassett, born September 
20, I8II; Cornelius, born March I5, I8I3; John, born May 26, I8I6.

6. Aaron, son of Simon Arent Vedder, married Elizabeth B. Spaun, January 12, I8+3; she was born at South Bethlehem, Albany County, N. Y., in - I8I9, died in Schenectady, June I6, I903; he died in Niskayuna, N. Y., on October 7. I886. Children: Mary, born February I4, I844, married Albert Van Voast on June 6, I863; De Witt Franklin, born September I2. I852.

\section{WALKER.}

Captain Philip Everard Meade Walker, U. S. A., retired, born at Winchester, Va., September 28, I876, son of Major: General John G. Walker, C. S. A., and Sophia M. Baylor, grandson of Dr. John Baylor and Marie Wiedener, son of Walker Baylor and Juliet Bledsoe, son of Colonel John Baylor and Lucy Walker, son of John Baylor and Lucy Todd O'Brien.

Walker Baylor was Captain of Third Dragoons in the Revolutionary War. Colonel John Baylor was a member of the Virginia House of Burgesses, I740 to I760, and Lieutenant of Orange County, and with Washington at Winchester. 


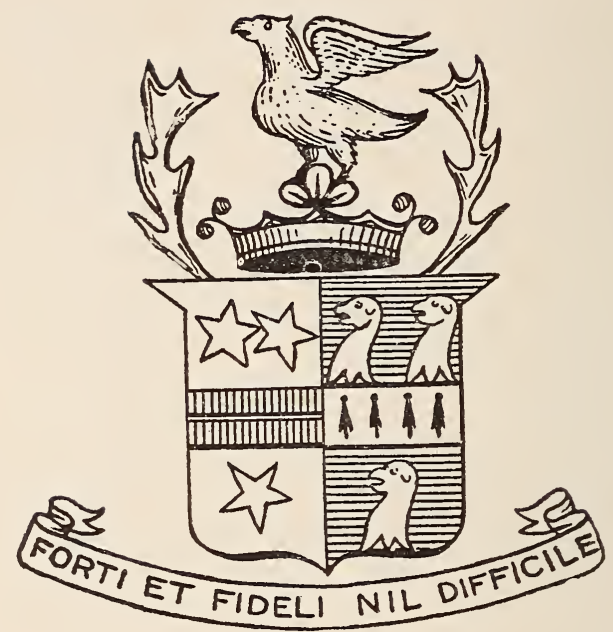

\section{HUGH VERNON WASHINGTON.}

"We live in deeds, not years; in thoughts, not breaths;

In feelings, not figures on a dial.

We should count time by heart throbs,

He most lives who thinks most, feel the noblest, acts the best."

To die is the common lot. But the Angel of Death never bent his wing to lift a knightlier soul to immortality than when this ripe scholar, this loyal friend, this courtly gentleman, this true humanitarian, passed at noon-tide from the press of battle to find the benison of God's sweet peace, beside the still waters.

Hugh Vernon Washington was one of earth's noblemen. He was Sir Launcelot and Sir Gallahad combined-not only a valiant, but a stainless knight. In an age of commerce he awoke the gentle accents of an age of chivalry; and while the love of combat was a passion which he never cultivated, his code of manners carried the imagination back to the romantic days when knighthood was in flower.

His lineage was ancient and honorable. The patrician blood which coursed his veins came to him from a host of illistrious forebears and rippled back without a stain to the Norman tiltyards. Democratic in principle, a loyal American to the heart's core, this modest gentleman nevertheless bore 
upon his eagle-crested shield the ducal coronet of Vernon of Normandy, A. D. IO52 ; and to the stars of his father's AngloAmerican line of descent he added the royal insignia of his mother's Scotch-Irish-English ancestors-Munster-MontroseSt. Albans.

But there was more in his person than in his pedigree to suggest baronial halls; and his real patent of nobility consisted, in the last analysis, of the inherent virtues which ennobled and beautified his symmetrical character.

James H. R. Washington, his honored father, was a rep. resentative of the illustrious family of Virginia from which sprang the renowned Commander-in-Chief of the American armies and the first President of the United States. The elder Washington was a banker and a planter. He was also a dominant figure in public affairs and held the office of mayor in two separate Georgia cities-Milledgeville and Macon. To the latter town he was a bulwark of defense during the dark days of the Civil War. His name is found among the charter members of both the State Historical and the State Horticultural Societies, two of Georgia's most beneficent and usefu1 organizations.

Hugh Washington's mother was Mary Hammond. She was the first real daughter to be enrolled in the National Society of the Daughters of the American Revolution, an organization of which she was a charter member, and she was also the founder of the Georgia branch of the N. S. D. A. R., and the first chapter regent in Georgia. The Mary Hammoni] Washington chapter of Macon is the pioneer sisterhood which commemorates her patriotic activities. She was also honorary regent for the State of Georgia. Mrs. Washington was the most notable woman of her day and time, endowed by nature with an intellect of rare power, to which the best educational advantages added something of the diamond's brilliancy of polish. The opportunities of travel and the delights of literature also contributed to her wide range of general information. But above everything else Mrs. Washington was characterized hy a sweetness of spirit which made her the embodiment of 
gentleness itself. At the age of eighty-five she was in full possession of her mental faculties and took the liveliest interest in current events. The Daughters of the American Revolution have most appropriately honored this gentlewoman with an exquisite marble bust in Continental Hall. Washingtor, D. C. It bears the following inscription:

FOUNDER OF THE N. S. D. A. R. IN GEORGIA.

"A Woman mixed of such fine elements That were all truth and religion dead,

She'd make them newly,

Being what she was."

Her father, Coicnel Samuel Hammond, was a distinguished officer of the first war for independence and a civilian of the most exalted rank. Subsequent to the purchase of Louisiana from Napoleon, he was made the first Governor of the district of Missouri, or Upper Louisiana, under the appointment of Mr. Jefferson, his headquarters being at St. Lcuis, where his children were born. Later in life he settled at Tarello, an extensive plantation to the east of the Savanneh River, and held many offees of trust and honor in the State of South Carolina. Fcr a number of years, in the early: part of his career, he resided at Savannah, Ga., where he səttled at the close of the Revolution; and while a resident of this State he represented Georgia for a term in the United States Congress. He was a patrior of unsullied reputation? and a man of the highest personal honor. On the pedestal of his daughter's marble bust it is recorded that he "gave sixty. years of public service to the cause of America."

At the famous old Mashington homestead, on the corner of Washington and College streets, in the city of Macon, on Acril 2, I86r, Hugh Vernon Washington first saw the light of day; and here surrounded by the scenes which welcomed his advent into this life and which furnished the playground of his youth, he fell tranquilly asleep on October 5, I9II.

It was not an ungentle providence which permitted him thus to die.

Half a century measured his life's brief span. But it was 
not in years alone that he lived, but in deeds of kindness, in sympathetic and tender heart throbs, in courageous endeavors which proclaimed his robust manhood, and in the sweet and gentle ministry of helpfulness to others. He also witnessed the marvelous scientific miracles of the most wonderful era of modern times.

Hugh IVashington receivel his preparation for college at Prəf. B. T. Hunter's school for boys in Macon: and, entering the University of Georgia in the fall of I880, he pursued for one year an elective course in the academic department. His ambition was to continue his farorite studies; but his aged mother needed his stout arm and his brave heart at home. Ever thoughtful and considerate of her, the high-minded Iouth sacrificed his own wishes and, at the end of his sophomore year, entered the Law School, taking his degree at commencement in I882. As a student he bore his blushing honcrs thick upon him. While an under-graduate, he won the first sophomore medal, offered as a prize for deciamation. He was one of the public debaters of the Phi Kappa Society in I88I, was the chosen anniversarian of the same organization in 1882 , and was one of the three picked debaters to represent his alma mater in the championship contest with Mercer Lniversity in the saine year.

For the practice of his profession he located in the home C \pm his boyhcod, and from the start rose steadily and rapidiy to the front. Modest to a fault, he neither sought nor desired public office: but, at the earnest solicitation of his fellow citizens, he became, when quite a young man, judge of the reccrder's court of Macon, and to this important office he brought the most substantial and solid qualifications.

Successful to a marked legree in the practice of law, he nevertheless scorned the feats of jugglery which belong to the professional charletan. Self interest never entered into the calculations of Hugh Washington. No tainted shillings ever clung to his clean fingers or glistened in his pure eves. He exemplified the ethics of the Ten Commandments. He practiced the courtly manners of the Old School; and truly it may 
be said of him that "in the silken glove of courtesy he mailed the iron grip of honor."

His genius was essentially constructive. He organized the Macon Athenæum, the Macon Public Library, the Bibb Agricultural Institute, the Bibb Humane Society, and gare the initial in:pulse to numerous important civic enterprises. He also held life memberships in both the Agricultural and Horticultural Societies of the State.

His distinguished ancestry, on both sides of the house, connected him with Revolutionary days and deeds, while his honored name was peculiarly fragrant with patriotic recollections. But he was worthy of his lineage. It took no stain from him. On the contrary, it borrowed an added wealth of association from his own splendid character. Conspicuously identified with various patriotic orders, he was LieutenantGovernor of the Society of Colonial Wars, Tice-President of the Oglethorpe Memorial Association; Vice-President of the Sons of the Revolution in Georgia, a member of the national organization of Sons of the American Revolution, and a member also of other patriotic and hereditary orders.

As an orator, he represented the Ciceronian type. His diction was faultless. Even in casual conversation it bespoke the cultured mind and the mature thought of the scholar. His acquaintance with books was vast. Nor was it by any means in shallow or superficial draughts that he drank of the Pierian Spring. He was often in demand on public occasions and was frequently called into other States to discuss important topics. His range of thought was marvelous; and from one subject to another-however widely separated-he could turn with the utmost ease. He was equally at home whether in contemplating the mystery of the stars, or in solving the problems of civic reform, or in bettering the conditions of agriculture or in espousing the cause of dumb animals. It was ever his delight to enjoy the sweets of country life. He loved to commune with nature. whether in her fields or in her forests; and to the development of the vast resources of his native state, much of his time was gratuitously and 
gladly given. His tireless brain was both a storehouse of intellectual treasure and a dynamo of nervous energy; he wrote as well as he spoke with the grace of an accomplished master upon a variety of themes; and he literally touched no subject which he did not adorn. He delivered the address at Andersonville National Cemetery in 1890 and the address on Conferlerate Memorial Day, in Augusta, in 1893, besides eulogizing the heroic dead of Dixie in other Southern cities; but perhaps none of these formal orations surpassed his impromptu Fourth of July effort, on board an English vessel, which bore the Union Jack, on Independence Day, rgog. He was at the time on a tour of the old world. Mr. Washington's apostrophe to the Star-Spangled Banner on this occasion thrilled and electrified even the British tars. While it emphasized his sturdy Americanism, there was no infraction of the law of good taste; and, without giving the least offense to any one on board, he vividly reminded his English cousins of the little scene at Yorktown in which another bearer of the name figured in the Independence Day celebration.

But the honor which gave perhaps the greatest satisfaction to Mr. Washington was his appointment by the Governor of Georgia to represent his native State officially at the Louisiana Purchase Centennial Exposition. The fitness of the choice was universally conceded. As the grandson of the first Territorial Governor of Missouri, as a representative citizen of Georgia, as a gifted public speaker and as a man of unblemished personal honor, he was pre-eminently fitted to grace this important role; and he represented the State in a manner which not only met the heartiest approval of the people of Georgia, but elicited the warmest commendation of Governor Terrell in his annual message to the General Assembly of the Commonwealth.

He was furthermore selected in 1907 to represent Georgia at the Jamestown Ter-Centennial Exposition, an enterprise of world-wide interest, the object of which was to commemorate the first permanent English settlement on the continent of North America. 
Under the terms of Mr. Washington's will, his alma mater, the University of Georgia, is made the recipient of a substantial gift, to be known as the James H. R. Washington fund, so called in honor of his father. He also made a similar bequest to Wesleyan College as a memorial to his mother. Still another legacy was left to Nercer University; while the National Society of the Daughters of the American Rerolution and the Missouri Historical Society were likewise substantially remembered by this ever thoughtful and generous benefactor.

The soul of pure unselfishness, it was never his own interest which he sought to promote-it was always the welfare of others; and there was not an act of his life which did not suggest the motto of the humane Oglethorpe-emblazoned on Georgia's earliest Seal- "non sibi sed alias."

Mr. Washington never married. But his wealth of af fection was lavished without stint upon his loved ones: and in the home circle he was the incarnate flower of every grace which makes life beautiful-the tenderest of sons, the dearest of brothers, the manliest of men. At historic Washington Place, and at beautiful Vernonwood, his belored country seat, he dispensed a hospitality which proclaimed him an ideal host. His genial wit, and his stmny spirit made him ever the sweetest of companions.

In the chalice of death he has found the elixir of life.

The hearts of those who loved him will continue to enshrine his image; and to them his memory will ever be as fragrant as the Arabian myrrh.

Till some sweet day, dear friend, adien! Did I not know that in God's paradise, where the tree of life is blooming, thou hadst caught the vision of the pure in heart. I might almost fancy that in some island-valley of Avillion thy soul had mated with the soul of Arthur-the kingliest of the storied knights-

Where falls not hail, or rain, or any snow

Nor ever wind blows loudly, but it lies

Deep-meadowed, happy, fair with orchard lawns

And bowery hollows crowned with summer sea. 


\section{EXTRACT FROM THE ETA RECORD.}

Mr. Washington was a devotel Chi Phi; and the following brief paragraphs are taken from the official organ of Eta chapter :

"Good-night, sweet prince,

And flights of angels sing thee to thy rest."

"In the death of Hugh Vernon VIashington, the whole Chi Phi brotherhood has sustained an acute bereavement; and the burden of a common grief finds articulate expression in Horatio's farewell to Hamlet. Fellow students amid the academic groves of Wittenberg, these kindred spirits were tound together $b_{i}$ hoops of steel. IVell Horatio knew and loved his fallen conrade. But the master-creation of Shakespeare's mind was not more truiy a prince in Denmark than was this noble scion of the South among his brethren of the mystic tye at Athens.

"Like Sir Philip Sidney, he was the flower of a chivalric race.

"Lpright, genial, cultured, philanthropic, a man of the loftiest ideals of personal and civic virtue, a friend whose lovalty never once wavered, and a Christian gentleman who exemplified in every act of his life the divine philosophy of the Golden Rule, Hugh Vernon Washington lived without reproach and died without fear. Eta chapter is bereaved in his death, but Heaven is happier for his coming home."

L. L. K.

The above sketch is by Lucian L. Knight, the Historian.

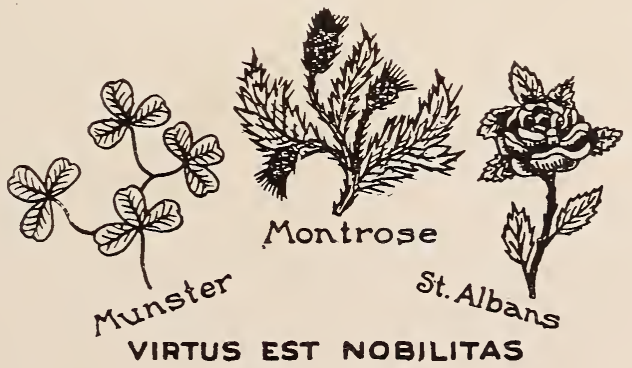




\section{OLD FALL,S CHURCH, VIRGINIA, AND ITS HISTORIC MEMORIES.}

Old Falls church was named from Great Falls on the Poto mac, one of the most picturesque spots in America and visited by tourists from Washington City, as Mt. Vernon is on the lower Potomac; all was originally the Washington estate. Ruins of the old mill owned by General Washington are still in good preservation at Great Falls. The Old Falls village church is built of brick brought from England before :h? revolution and is one of the three, including Powhick and Christ Church, Alexandria, Va., identified with the Washington family in pre-revolutionary days, General Washington having been a vestryman in each. This fact has been commemorated by tablets placed by the Society for Preservation of Antiquities in Virginia. Falls church has been restored by the Virginia Society of Patriots and Founders and the marker placed there October 5, I9II, by the D. A. R., under the direction of the Regent of Falls Church Chapter, Mrs. Callendar, wife of the rector. Hon. Hugh Vernon Washington, of Macon, Ca., was expected to speak at its unveiling, but on that very day he was suddenly called to a higher life.

In the old church yard, half hidden by huge cedars and oaks, many celebrities lie buried. Among them Lord Fairfax, of the Washington family, and John Ball, brother of Mary, the mother of George Washingion; Washington's only sister, Elizabeth, from whose marriage to Colonel Fielding Lewis the lineage of numerous descendants in Georgia and the South are now established in historic records.

Memorial to Hon. Hugh Washington.

To the D. A. R. of Ceorgia, who loved and admired Hugh Vernon Washington for his personal character no less than as an associate in patriotic endeavor, the following from the Washington Evening Star will be most interesting:

"Old Falls Episcopal church at Falls Church, Va., has received a memorial in the shape of two handsome vases in 
memory of Hugh Vernon Washington, of Georgia, formerly lientenant governor of the Society of Colonial Wars in Georgia and compatriot of the Order of Washington, the headquarters of which is in this city and which has Rear Admiral Charles H. Stockton, U. S. N., as commander.

"Mr. Washington was a collateral descendant of General Washington. The special services marking the presentation of the vases were held Saturday afternoon, October 5, at 5 o'clock and were under the direction of Mrs. W. E. Callender. Regent of Falls Church Chapter, D. A. R.

"Dr. Joseph G. B. Bulloch, chancellor and historian of the Order of Washington, delivered an eulogy on Mr. Washington and a member of the Colonial Wars spoke of his work in that organization. Delegations were present from a number of patriotic societies."

Dr. Bulloch spoke in part as follows:

"Iradies and Gentlemen, Companions of the Order of Washington: It is with commingled feelings of pleasure and pain that Mrs. Callendar and myself have the honor to present to this historic old church, where for many years the illustrious Vashington was a vestryman, these beautiful vases as a memorial to our lamented companion of this order, Hon. Hugh Vernon Washington.

"In these day's we appear to be in a transitional stage of the race's development and therefore there are forces which seem today to pull us backward and others which urge us forward. We hence see how important it is that the forces which tend to progress should have as leaders men and women capable of resisting evil tendencies and who are able to conduct the human family to a happier and better state of existence.

"When, therefore, we lose one of our leaders in the forward movement for the betterment of mankind we suffer a severe loss. A year ago our beloved companion, Hon. Hugh Vernon Washington, passed to the great beyond on the very day he expected to make an address in this church and present to it the tablet in memory of General Washington. who was a vestryman in this church. 


\section{We NeEd Such Mex.}

"Hugh Vernon Washington was descended from illustrious ancestry, not only was he a Washington by descent, but had as an ancestor the revolutionary hero, Colonel Samuel Hammond. We need such men as Mr. Washington in these trying periods of our existence to aid in guiding us through the mist which surround us on all sides, like him, who was full of love. kindness and charity for all, whose example must have aided man to attain a more exalted station.

"Mr. Washington was of fine appearance and a splendid orator. Well do I remember his oration at one of our earlier banquets of the Sons of the Revolution of the State of Georgia, which Society afterward was honored in having him as an offcer. He was a loyal friend, a loving brother, a devoted son, and lived a life full of good deeds. He sought to bring the sections together in brotherly love. He was a true patriot and an officer in different societies. As commissioner general from Georgia to the Louisiana Purchase Centennial Exposition he rendered conspicuous service to the State and Nation.

"We, therefore, in behalf of the donor, in presenting these beautiful vases to the rector for this old church, feel that they are well placed and hope that future generations when looking upon them and upon the tablet to General Washington will consider that they commemorate two men who were beacon lights at different times to mankind. To his sister, Mrs. Ellen Washington Bellamy, we extend our sincere sympathy in the loss of one so dear to her and to many bereaved friends." 
OF

\section{Hon. Hugh Vernon Washington To} THE DAUGHTERS OF AMERICAN REVOLUTION AT CONTINENTAL HALL

It was a most beautiful sight upon that night when at the Continental Hall the bust of the Honorable Hugh Vernon Nashington was nunveiled and presented to the Daughters of the American Revolution for the Hall.

It was a grand sight to see, at the opening of the ceremony, the pages march in, bearing the flag of our Country, followed by the Maryland Committee of the "Star Spangled Banner Celebration" and the members of the Order of Washington, bearing at their head the Standard of the Order and also representatives of various patriotic bodies.

Cpon the platform were many persons of prominence representing the different societies. The President General of the D. A. R., Mrs. Story, with the grace which becomes her, opened the meeting and requested Dr. Bulloch to introduce the speakers. Glowing tributes were made by Mrs. Bryan, the daughter of the late Admiral Semmes and by Hon. Whitehead Kluttz, ex-President of the Senate of North Carolina, and by Dr. J. G. B. Bulloch, Chancellor General of the Order of Washington, after which came the ceremony of unveiling.

Hugh Vernon Washington was "A man, take him for all in all, we shall not look upon his like again." 


\section{SMITHSONIAN REPORT, PROCEEDINGS OF TWENTY-THIRD CONTINENTAI. CONGRESS, THE DAUGHTERS OF THE AMERICAN REVOLUTION.}

The President General: We look forward to a program of great interest this evening, inasmuch as it is an occasion to which we must all respond with great enthusiasm-this celebration of the "Star Spangled Banner." It is peculiarly fitting and appropriate that these ceremonies, and this program prepared for us, should be preceded by an act of loving remembrance of consecration to an American hero of today, one who was known to us all and beloved, not alone because his mother was one of the first and best beloved of the members of this organization and because his sister has served faithfully and well the Daughters of the American Revolution, but because of his own great value and splendid character.

I am pleased to present to you Dr. J. G. B. Bulloch of the Order of Washington, who will take the ceremony of unveiling and presentation. "Madam President General, ladies and gentlemen :"

"I have the pleasure of introducing to you a lady well known in your Society and of distinguished lineage, the daughter of Admiral Semmes of Alabama, Mrs. Bryan. (Applause.)

Mrs. Bryan: Madam President General, Members of the Congress, ladies and Gentlemen: "We live in deeds, not in years. He lives most who does most and who acts for the best." Death never summoned a more cordial gentleman, a more devoted son, a kinder brother, and a more loyal friend than when that summons came to Hugh Vernon Washington of Ceorgia. Born in April, I86I, he first saw the light of day in the very home where God came to summon his spirit, where he crossed the dark valley into the Great Beyond, seeking the light of that Great Light of the God above, whom he had loved and worshipped here below. Born of noble parentage, going back to the Vernons of Normandy, and Edward the first of England and Phillip the third of France, it was one of his 
prides to know that he was nearly related to the family of the great George Washington, to whom today we owe our independence--this great country that spreads its arms across the continent.

Hugh Vernon Washington first went to school as a boy in the little school at Macon, Georgia. He rapidly rose and entered the University of Georgia. He chose law as his profession in life and soon rose in that profession and made a name for himself in his native State. There are lawyers and lawyers. He was one to whom no mercenary consideration could force to do a wrong thing. Charity frequently blended with his kind acts. He was a great humanist and philanthropist. He loved his native State and was actively interested in everything that tended to her progress. When we come to lay tribute at the feet of this great man we feel that in honoring him we honor ourselves. It is very easy to sing the praises of those who have made themselves illustrious, but when we come to portray the character of a man who was noble and generous, it arouses our kindly impulses. A grasp of the hand was given those in trouble; his purse assisted those in need. Many today stand and praise the kind acts of Hugh Vernon Washington.

"Lives of great men all remind us,

We can make our lives sublime, And, departing, leave behind us, Footprints on the sands of time. Footprints that perhaps another Sailing o'er life's solemn main,

A forlorn and shipwrecked brother Seeing, shall take heart again."

Dr. Bulloch: Madam President General, ladies and gentlemen, I have the pleasure to introduce to you tonight a gentleman from the State of North Carolina, which State has never been behind in the history of America, the Honorable Whitehead Kluttz, former President of the Senate of North Carolina, a member of the Society of the Sons of the Revolution, 
of whicin organization the Honorable Hugh Vernon Washington was Vice-President for the State of Georgia.

Mr. Kluttz: I count it a privilege tonight, as the represertative of the Sons of the Revolution, to stand in the afterglow of the benignant personality of Hugh Vernon Washington. This marble is not so white as his character, not so lasting as his influence. Such a life never dies. Unseen, disembodied, it is here. Its echoes roll on forever.

"Kind hearts are more than coronets, And simple faith than Norman blood."

a worthy wearer of the most illustrious name in the history of liberty, the name of Washington, an active officer of the Sons of the Revolution, he was primarily a patriot of the race of 1776 .

At the knees of a patriot mother, a distinguished member and founder in Georgia of your Society, he learned a limitless devotion to his land.

The mother alone is nobler and more beautiful than the wife. I think it a very great and beatiful thing that at ihe fore-front of the history of this republic, whose life is so largely what its women make it, there stands forever the figures of two types of womanhood, Mary, the mother of Martha, the wife of Washington. With their own hands they knitted and sewed and ministered for the soldiers of their country, and in no hour of storm and stress, however dark or however great, did their counsel or their cheer ever fail. In their eyes was seen the lovelight that lit the lowly mother's face above the manger in Bethlehem, was reflected in the divine radiance that shone in Mary's eyes when she was "last at the cross and first at the tomb."

The story of America, up to those dark hours, is the unmatched miracle of world history. I am of those who believe that as we have grown materially, we have not dwindler morally.

The spirit of 1776 is not dead. It lives in the breasts of countless women, devoted as those of the Revolution, in the 
breasts of millions of men who at the first call of danger will spring to arms and "stand a wall of fire about their native land."

Hugh Vernon Washington was of the South, the South once divorced and estranged, but now, thank God, forever remarried to the Union of the Fathers.

Once again has the flag been dyed with the red badge of American courage; and Yankee Doodle and Dixie are inseparably interwoven in the music of our marching armies.

It is a time when partisanship should sleep, when cavii should cease.

I bring you this final message, caught from the patriotic life we commemorate tonight:

Our Country! May she ever be "the hope of all who suffer, the dread of all who wrong!"

"It gives me great pleasure to present to you, Dr. Bulloch of the Order of Washington."

Dr. Bulloch: Madam President General, Daughters of the American Revolution, ladies and gentlemen: On occasions when the descendants of illustrious ancestors meet to discuss the history of the past, and resolve that hereafter they shall be an example to those who come after, and emulate the good deeds of our forefathers. It is said that we have no history in America. They who make such an assertion are either very ignorant or else they have not studied history in the proper way. Surely the civilization of the Aztec and of the Toltecs, surely the mound-builders and the cave dwellers and the ancient buildings of this country now in decay, sufficiently attest and impart what America is. Here came the Spaniard, with his civilization, and later on that noble band from Northern Europe, those individuals who went across the stormswept seas, knowing nothing about the strange land they were to enter, there to fight disease and pestilence and the savage, but they at last gained their freedom. This vast multitude who came to this country berame welded together and during the Revolutionary War fought the Battle of Princeton and of Yorktown and of Bunker Hill, of King's Mountain. Think of our heroes of various nationalities-Washington, Lee, 
Pulaski, Marion, Hammond, Greene and Sumter. These arz the men who made the history of America.

Another assertion is made that the settlers of this country were ordinary people. Do you consider the Puritan, the Scot, the Huguenot (whose blood flows in the reins of many of us), the Swede; and the enterprising Hollander, ordinary people? Those are the individuals who came across into this strange land, sleared the forests, and laid the foundation of our present cirilization.

The records show that there were many splendid people who came to this country, not only the sturdy yoeman, but many gentlemen. These same records prove that we have as fine blood as flows in the old country. Historians very of ten make a mistake. They seem to pass by certain people, looking, as it were, from a mountain-peak, taking only a bird's eye view of matters; hence by their jealousy and partisanship they pass individuals by. But the genealogist, picking up the thread, goes along and shows the ancestry and gives the position to which they are entitled. It is true there are individuals whom we ought to consider above the rest; so great are they that we class them among the stars of the first magnitude, but there are others who seem to have been passed by. It is our duty to show into which category they belong, to show their value and their worth. Some are noble through generations-the very corner-stones of the foundation upon which States are built.

Hugh Vernon Washington was a man of wisdom, justice and moderation. "He was a man, take him for all in all, i shall not look upon his like again"- - man who lived not for himself but for others, a man of the grèatest principles and we, of the Order of Washington, are not only proud but honored to honor the name, the name of that man, of that gentleman, the Honorable Hugh Vernon Washington.

Madam President General, and Datighters of the American Revolution, and officers of the various orders, Sons of the American Revolution, the Societies of Colonial Vars, the Aryan Order of St. George and the Colonies, Ogletlorpe Nemorial Association, Society of the Cincinnati, the Order of Washing- 
ton, in behalf of the donors of this bust of Hugh Vernon Washi.igton. I have the honor and extreme pleasure of presentin... to you, Daughters of the American Revolution, for Memorial Continental Hall, the bust of Hugh Vernon Washington. (Great applause.)

The bust was unveiled by Mrs. Eleanor S. Washington Howard, of I irginia, and Mrs. Ellen Washington Bellany, of Ceorgia.

A wreath was placed at the base of the bust by Miss Evalyn Pike. of Maine.

Mrs. Bellamy: Madam President General, Daughtars of the American Rerolution, and Sons of the American Revoluticn. Compatriots of the Order of Washington: I wish to thank all who have contributed to this memorial. No truet patriot and more loyal friend of our own and of his kindred organizations will ever be memorialized in this beautiful Temple of Patriotism, made possible by his generosity: stately and white and dianified it typifies his own character. His noblest legacy is an echo of the last greeting of his mother to her beloved daughters. "May Our Society ever be a helping hand to Our Country." There is patriotism in peace no less than in war, that patriotism strives for good government, better citizenship, a ingher civilization. He gave his best to the betterment of the world. Grandson of a hero of the American Revolution, son cf a patriot mother, he learned from her lips the story of Valley Forge, King's Mountain and Yorktown and was filled with a love of country that ran through his life like a golden thread, enriching every theme-inspired to high resolve and noble endeavor for his country's good. "He abides with us in spiritual consciousness."

The President General: "In the name of the National Society of the Daughters of the American Revolution, with deep appreciation we accept this priceless treasure, priceless because of the great tenderness and reverence we feel for the man who is gone, priceless because of the memory and the inspiration to all who knew him." (Applause.)

Mrs. Gray, of Missouri: "MIrs. John R. Walker, of Missouri. who was Chairman of this Memorial Committee has passed away, and I ask the courtesy of having the House to rise in her menory." (The Congrass rose.) 
The Chaplain General, Mrs. Lockwood: "I knew this man from his boyhood; one of the rarest men I have ever known; so far above the sordid and selfish was he, that his spirit seemed to soar aloft. He was a spiritual man of the highest type. His mother was the very first woman from the Southland who came to our resete and helped to organize this Society. When he left the hospital in Baltimore a short time before his death, he and his dear sister, returning to their home in Georgia, stopped in Washington; as I was passing through the park I met them. He said, 'I am a very sick man; I wanted to be out in the open; I did not know that I should have this good fortune.' It was in the spring of the year,- to hear the robins sing-I love the robins. Just at that moment two robins floated over us and began to sing in the trees; that memory has gone with me through the days, and I have always felt it was the benediction of that lovely man. In memory of his Mother and of this devoted Son, I lay this rose upon the bust."

Miss Harriett Harding sang "America." (Prolonged applause.)

Hon. A. S. Goldsboro, of Maryland, of the Star Spangler Banner Association: "Daughters of the American Revolution and Guests: Any man who has the privilege of standing face to face with a body of women like these belonging to this Congress, feels himself more than honored; I say this because any man just at this moment who is not conscious of at least a quicker pulse when the word Patriotism is spoken, is a man absolutely dead to all feeling. When I stand face to face with a body of women whom I know are now laboring, and have been laboring for years, for the sole and specific purpose of cultivating the sentiment of Patriotism, I know that by reflex action I am gathering some of the benefit of these labors, is it a wonder that I bow my head reverently-that I am in the presence of the queens of Patriotism; who are the women who make this country well worth living in? My friends, you and I are continually alluding to that word, "Patriotism"-without stopping to catch the full measure of 
its meaning. When we stop to think that there is in it, and of it a certain unseen and indescribable emotion that siezes upon a man in time of danger, and makes him throw his body and fortune on the altar of his country, be the sacrifice what it may. Whsn you think of Patriotism in words like that, we cannot speak of it in trivial terms-but we must talk of it as if we were dealing with sacred propositions. When I sat here tonight and witnessed the beantiful ceremonial of the unveilirs: of that bust, I thought how many young men in the State that face represents, will every time they hear that name mentioned and realize that face and body and head are here in the thoughts of the people of the country; but, whose hearts will thrill with the desire to emulate the life there represented; and whenever the time comes that they can prove that they too are men, will catch the ideal and remember the face as an inspiration. My friends, when you think of Patriotism, we know that it is the only great power and the only great force that makes men and women forget their selfishness, forget their avarice, forget everything but their country's welfare, I say it is a sentiment born of God and nurtured of Heaven, and is for every man and woman a sacred sentiment. No man or woman could look upon a ceremonial intended to be a tribute to a patriot without realizing what it means, not to ourselves, but to the future. That man is made none the better because his bust is here, God has taken to His own, but his deeds and spirit form a motive for emulation. (Applause.) It is the impression that we are to make upon the younger generations of the land that will furnish a theme for the sweetness and excellence and perfection of its future; and every time that a celebration like this takes place, that has behind it the absolute purity of a patriotic motive, it is national in its bearing. If it is national in its possibilities, it curnes to you with a significance that if there is any practical reality in the perfection of patriotic organizations, it will find its expression in deeds when the occasion arises, do not deceive yourselves by the belief that Patriotism because it has existed from the time of our ancestors will live without effort to keep it alive. There are times that are detrimental and subversive to Patriotism, 
just as there are times when we throw away that which appears to come from the spirit of the Most High, an exalted sentiment from the Great Being above. It needs some splendir sentiment to make a person ready and willing to sacrifice everything to patriotism, and here is where we find it nurtured, here in the body of women who inherited the patriotism of 177 i): here in this Temple of the Vestal Virgins, who will keep the flame of Patriotism alive and become the distributors of this same sentiment throughout our land."

A page from Illinois sang the "Lası Rose of Summer." The Marine Band played "America." (Prolonged applause.)

Sons of the American Revolution, The Sons of the Revolution, Society of the Cincinnati, Society of Co!onial Wars, The Order of Washington, participated in the ceremonial.

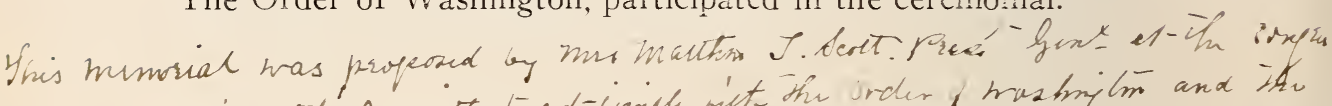

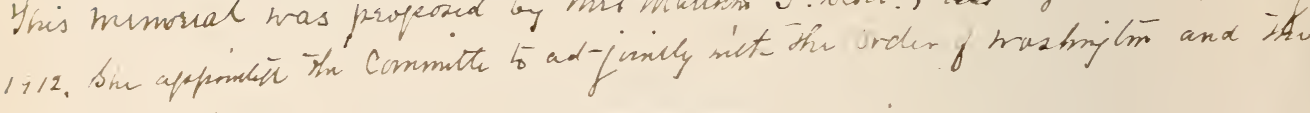

\section{WASHINGTON.}

The Order of Washington numbers amongst its Companions many by the name of Washington, and descendants of the name, and we find upon our roll the following:

Lawrence Washington, Colonel William DeHertburn Washington, Thomas Campbell Washington, R. Wirt Washington, Captain Thomas Washington, and the late Hon. Hugh Vernon Washington, besides the late R. Mason Ball, Paymaster, U. S. N., one of the nearest relations of the illustrious General. Also Philip Contee Hungerford and John Taliaferro Brooke.

Thomas Campbell Washington was born in Charles Town, West Virginia, on February 9, 1875, and is the son of Bushrod Corbin Washington and Katharine Thomas Blackburn, and the grandson of Thomas Blackburn Washington and Rebecca Janet Cunningham, and great grandson of Bushrod 
Corbin Washington and Maria Blackburn, and a great, great grandson of Corbin Wiashington and Hannah Lee, and a great, great, great grandson of John Augustine Washington and Hannah Bushrod, and great, great, great, great grandson of Augustine Washington and Mary Bail. John Augustine Washington was County Lieutenant of Westmoreland County, and Recruiting Officer during the Revolutionary War, Member of Convention July, I775 and May 1776 , and a lineal descendant of Colonel John WTashington, I659-I666, Member of House of Burgesses, Church Warden of White Chapel, Virginia, Colonel of Virginia Forces against the Indians.

Thomas Campbell VTashington married September 7, I9Io, Elizabeth Harlowe Holmes, the cnly daughter of Judge Lemuel LeBaron Holmes, of Mattapoisett, Massachusetts, and through this union have one son, Thomas Campbell Washington, Jr.

LAWRENCE WASHINGTON was born in Fairfax County, Virginia, on January I4, I859, and is the son of Colonel John Augustine Washington, C. S. A., and Eleanor Love Selden, grandson of John Augustine Washington and Jane Charlotte Blackburn, great grandson of Corbin Washington and Hannah Lee, great, great grandson of John Augustine Washington and Hannah Bushrod, great, great, great grandson of Augustine Washington and Mary Ball, great, great, great, great grandson of Lawrence Washington, member of House of Burgesses, I742-I745, I747-48-49, from. Fairfax County, and who married Mildred Varner.

John Augustine Washington was County Lieutenant of Westmoreland County, Virginia, and Recruiting Officer, member of Conventions of July I\%, Ir75 and May 6, I 776 , for TTestmoreland County.

Colonel John Washington, the ancestor, was in the Colonies from 1657 to 1666 , and a member of the House of Burgesses, October 23, 1666-1676, from Westmoreland County, Virginia. and was Colonel in Indian Wars. He had a grant of land on which Mount Vernon now stands. Te thus see that Lawrence Washington was a linea! descendent of Colonel John Wash. 
ington, that he was a close relative of General George Washington, and also descended from the ancient families of Selden, Blackburn, Lee, Ball, and others.

R. WirT WAShINGTON was born in Virginia, and was descended from a double line of Washington. From the celebrated William Wirt, the Bayards of New York, the Taylors, the Ayletts, and the Butlers, and the Paynes, and Warners.

He is the son of Robert J. Washington and Elizabeth Wirt, daughter of Dr. Wirt, son of Hon. William Wirt, grandson of Lawrence Washington and Sarah Tayloe Washington, daughter of William Augustine Washington, great grandson of William Augustine Washington, above, and Sally Tayloe, great, great grandson of Augustine Washington and Ann Aylett, great, great, great grandson of Augustine Washington and Jane Butler, great, great, great, great grandson of Lawrence Washington and Mildred Warner.

Lawrence Washinigton was of another line of Washingtons of Virginia, and married, as has been stated, Sarah Tayloe Washington, daughter of William Augustine Washington, who served for a brief period in Mercer's Regiment during the Revolutionary War. He was the great, great grandson of Colonel John Washington, who was in Virginia from 1657 io I677, and was a member of the House of Burgesses from Westmoreland County, Virginia, sessions, October 23, I666-1676, and Colonel in Indian War. Augustine Washington was a member of the House of Burgesses for Westmoreland County, Virginia, August 22, I754, I756, 1757. See Colonial Register, by William and Mary Stannard.

Wiliaiam DeHERTburn Washington, deceased; son of Lewis William Washington and Ella Bassett; son of George Corbin Washington and Eliza R. Bealle; son of William Augustine Washington and Jane, daughter of John Augustine Washington; son of Augustine Washington and Ann Aylett; son of Augustine Washington and Jane Butler; son of Lawrence Washington and Mildred Warner; son of Colonel John Washington. William Augustine Washington was in Mercer's Regiment in the Revolutionary War. 
Thomas Washingtox, Captain, United States Navy, was born at Goldsboro, North Carolina, June 6, I865, the son of James Augustine and Virginia Pope Washington.

He entered the Naval Academy at Annapolis in I883, and was graduated from there in I887. He then served successively on the "Enterprise," the "Alliance," "Montgomery," "Terror," and "Indiana," on which last ship he was a lieutenant during the war with Spain and the battle of Santiago.

In 1902 Captain Washington went to the Asiatic Stations as Flag Secretary to Admiral Evans. Since then he has commanded successively the "Dolphin," on the Atlantic, and the "Yorktown," "Denver," and "Charleston," on the Pacific Station.

On June I2, I900, he married Miss Genevieve Fuller Clement, of Morrow, Ohio. They have one son, John Clement Washington, born April I, InOI, and another son born since.

\section{IVHITE.}

Richard Neville White, of 253 Depew Ave., Buffalo, N. Y., is of distinguished Colonial ancestry, and is of the I 3 th generation in America. Among early American ancestors, from whom direct descent can be traced, appear the names of W'illiam Pinkney, of Maryland, General Otho Holland Williams, Sr., and General Otho Holland Williams, Jr., Hon. William Smith of Pennsylvania and Maryland, Sir George Yeardly of Yirginia, Isaac Smith, Jr., of Virginia, Lieutenant-Colonel John West of Virginia, Colonel Edmund Scarborough of Virginia, Major-General John Custis of Virginia. Besides this 
list will include two Lord Mayors of London, of Shakespeare's time, and through his mother there is a connection with Richard Neville, the famous King-Maker of the Wars of the Roses, between the Houses of York and Lancaster.

Richard Neville White was born in Beach Haven, Ocean County, New Jersey, and is the son of Otho Holland White and Constance Neville, and the grandson of Rev. John Campbell White and Mary Smith Williams, daughter of Edward Greene Williams and Ann Gilmor, and son of General Otho Holland Williams, who resided in Maryland from 1749 to I794, and who was a Lieutenant in the Maryland Militia in I775, and afterwards a General in the Revolutionary War. He married Mary Smith, daughter of Hon. William Smith.

Richard Neville White also descended from Hon. Isaac Smith, Jr., who was a member of the House of Burgesses from Accomac County, Virginia, in 1775 , and a member of Convention, May 6, I776. He married Elizabeth Custis Teackle, and had: Mary Ann Smith, who married Gilmor, and had: Ann Gilmor, who married Edward Greene Williams, and had: Mary Smith Williams, who married Rev. John Campbell White, and had: Otho Holland White, who married Constance Neville, and had: Richard Neville White.

His White ancestors are not Colonial, but are an American branch of the Argyle Campbells, of Scotland. General Otho H. Williams, Sr., led the famous Charge of Eutaw Springs, which saved the American Army and made him a general. While in the Revolutionary War was made a prisoner by the British. Was exchanged for the celebrated Major Ackland, a priconer at Saratoga Springs. Major Ackland deserves notice not only as being the husband of the noted beauty, Lady Harriet Ackland, but as being the only Englishman who ever gave his life to defend the honor of Americans. On Major Ackland's return to London, one of his club mates spoke of Americans as cowards. The Major demanded a retraction, which not being forthcoming, the Major challenged him and fell in that duel.

Richard Neville White is a member of the Society of the Cincinnati, and of the Order of Washington. 


\section{WILLEY.}

William Lithgow Willey, born at Boston, Massachusetts, May 30, I857, son of Tolman Willey and B. Langdon Lithgow, grandson of William Lithgow and Hetty Green Langdon, son of Arthur Lithgow and Martha Bridges, son of William Lithgow and Sarah Noble.

Arthur Lithgow was Quartermaster and Lieutenant in Colcnel McCobb's Regiment, Revolutionary War. William Lithgow was Lieutenant at Fort George, 1737, in command Fort Richmond, I7 48 , Colonial Judge in $\mathrm{I} / 60$. and Colonel of Lincoln County Regiment.

\section{WOODRUFF.}

General Carl Augustus Woodruff, born at Buffalo, New York, August 8, I8+1, son of Israel Carl Woodruff and Caroline Augusta Mayhew, son of Thomas Lowery Woodruff and Anna Carl, son of Aaron Dickinson Woodruft and Grace I.owery, son of Elias Woodruff, Captain Commissary Department, New Jersey Militia, in the Revolutionary War, and Mary Joline, son of David Woodruff and Eunice son of John Woodruff and Sarah Ogden, son of John Woodruff and Mercy Carle, son of John Woodruff, arrived in Massachusatts, 1638, founder of Southampton, Long Island; and Annie Gosmer. 


\section{WRIGHT.}

Marcus Joseph Wright, born at Purdy, Tennessee, June 5, I83I; son of Major Benjamin and Martha Ann (Hicks) Wright; educated in the common schools and academy at Purdy, Tenn.; studied law and engaged in practice in early life; was clerk of the common law and chancery court of Memphis, Tenn., I853-61 ; assistant purser of the U. S. Navy Yard, Memphis, I850-54; entered C. S. A. May, I86I, as I iettenant-Colonel of the I54th Senior Tennessee Infantry, and with four companies of his regiment and a battery of artillery occupied and fortified Randolph, Tipton County; he led his regiment in the battle of Belmont, November 7, I86I; was military governor of Columbus, Kentucky, February to March, I862; again led his regiment in the battle of Shiloh, April 6-7, I852, and was assigned to the staff of General B. F. Cheatham, in the Kentucky campaign as Lieutenant-Colonel, June-September, I862; he was appointed Brigadier-General, December I3, I862; commanded a brigade in the Chickamauga and Missionary Ridge campaigns; he was in charge of the district of Atlanta, I863-4, until its evacuation: he subsequently commanded the districts of Macon, Georgia, and North Mississippi and West Tennessee; he was sheriff of Shelby County, Tennessee, I867-68, and on July, i878, was appointed agent of the U. S. War Department, to collect Confederate records, which resulted in "Official Records of the War of the Rebellion"; he is author of "Reminiscences of the Early Settlers of McNairy County, Tennessee," I882, "Lif of Governor Blount," I884, "Life of General Winfield Scott, in Great Commander Series," I894; he is also author of: "Memoirs of General Robert E. Lee, with General A. L. Long," I896. and co-author of "American Reference Library," ( 6 volumes) I900; he prepared and printed, privately, Sketch of Augustus, Duke of Kent, for which he received the thanks of Queen Victoria, The Prince of Wales, and Princess Louise; he also contributed many biographical sketches of Confederate Army Officers to various reference works; also author of 
"Social Evolution of Woman," "General Officers of Confederate Army," and "Tennessee in the War of I86I-I865"; married twice, first, Martha Spencer Elcan, of Memphis, and had issue; second, Pauline Womack, of Alabama; member of $\mathbf{s}$. A. R., Southern Historical Society, Washington Historical Society, Honorable Member of Alabama Historical Society, and of The Order of Washington, of which he has been acting Commander General, and is now Vice-Commander General of the Order.

By his marriage to Pauline Womack, daughter of John Womack and Ann Miller Beville, he had:

I. John IV. Wright, Captain U. S. A., married Helen Eliza Hyde, and had:

\section{Pauline Wright.}

II. Howard P. Wright, Special Agent, Department of Justice.

III. Casey Wright, who married William Waller Dinwiddie, son of William Walthall Dinwidldie, and had:

I. Marcus Walthall Dinwiddie.

2. Stanley Womack Dinwiddie.

3. Alva Wright Dinwiddie.

John Womack Wright was born in Kirkwood, Missouri, July I0, I876, at which place his parents, who were from Tennessee, were temporarily residing. He was educated in the public schools of Washington, D. C.. and subsequently was graduated from the Columbian College (now a part of George Washington University), in I892. He was a student at William and Mary College, Williamsburg, Virginia, and also a law student at Columbian University. He was appointed a First Lieutenant in the 5 th U. S. Volunteer Infantry, in June, I898, and was later promoted to Captain. He was appointed a Second Lieutenant in the U. S. Army, in April, I899, and has since been promoted to First Lieutenarit and Captain. On August I, I9I 2, he was detailed at the War College on the General Staff Corps in Washington, D. C. He has served in Cuba and the Philippine Islands.

Howard Paul Wright was born in Washington, D. C., 
February 26, I88I. He was educated in the public schools of the District of Columbia, the Capital University School, and various private schools. He attended Georgetown University, and in IgI 2 was graduated with the degree of Bachelor of Laws, and Master of Patent Laws. In I9I 3 he took the PostGraduate law course at Georgetown University, and receiveri the degree of Master of Laws. He was admitted to the Bar of the District of Columbia on February 2I, I9I4. On March 6, I9I4, he was appointed Special Agent of the U. S. Department of Justice, and assigned to duty in Texas, with headquarters at Dallas, which position he now holds.

The Wright family came from England to America as early as I728. They were descendants of Jeremy Wright, of Suffolk, born in I608, third son of Thomas Wright, of Keneston, Norfolk County. (See Burke's Landed Gentry.) He married Anne, daughter of Richard Bancroft, and had a son and daughter. The son was Sir Robert IV right, who was Chief Justice of the King's Bench at the trial of the seven Bishops. In the time of James II he was an eminent jurist. He married the daughter of the Bishop of Ely. His son, Robert Wright, of Sedgefield in Durham, went to South Caroliná. where he was made Chief Justice. His son, Sir James Wrighi, was Governor of Georgia, being the last royal governor. Five Wright brothers of the same family came from England to America in I728. They were cousins of Robert and James Wright. The eldest of these was Benjamin Wright, whose eldest son, John, married Miss Tarner, and was Captain in the Second Georgia Regiment in the War of the Revolution, serving during the entire war. He died in Savannah, Georgin, in I8o9. His eldest son, Benjamin, was born in Savannain, Georgia, and was an officer of the 39th Infantry, serving under General Andrew Jackson in the Creek War. He was wounded. and afterwards promoted for gallantry at the battle of the Horse Shoe. He served subsequently in the Mexican War. and died at Purdy, Tennessee, in I860. (See Historical Collection of Georgia, page 682. .)

Major Benjamin Wright had two scns, Marcus J. Wright. and John V. Wright. 
The Arms of the Wright Family are: Blazoned, sable a chevron engrailed argent between three fleurs de lis, or on a chief of the last as many spear heads, proper, all within a border wavy ermine. The Crest is a dragon's head. 'The Motto, "Mens Sibi Conscia Recti."

\section{YOUNG.}

Laurens Garlington Young, born I85 I, civil engineer, Union, South Carolina; married I887, Namie Hunter, born I855; children :

I. Imogen Hunter, born I889, married I9I2 William Farr Gilliam, born I870, and had William Farr Gilliam, Jr., born IOI3.

2. Frances Elmira, born is?

3. Mamie Garlington, born I893.

4. Caroline Gibbes, born I898.

5. John Laurens, born IS99.

6. Calhoun Hunter, born 1903.

Mamie Hunter is a daughter of John Calhoun Hunter, * born I844, and Frances Elmira Aughtry, born I844, married I864; who was a son of James Hunter and Margaret Burell. married 1825 ; son of James Hunter. who came to this country in I78o. Margaret was a daughter of Dr. John Burell, who came to this country as a surgeon with Lafayette in I779, and his wife Patience. Frances Elmira is a daughter of Alfred Roe Aughtry, born I8Io, son of David Aughtry, who came to this country in I780, who married Anne Glenn Sims, born I8I I, daughter of Reuben Sims, born I $7 \mathbb{4}_{4}$, and Mary Hopkins,

* John Calhoun Hunter was at Wofford College, Spartanburg, S. C., when the Civil War began. In the spring of 1862 when only 17 years old he and his roommate, Daniel Epps, left college and joined the Macbeth Light Infantry. a Union County organization, then in Virginia, and fought through the remaining three years of the war, participating in all the battles in which this famous company was engaged. When his mother learned that he had volunteered, she sent "Old Robin," the colored servant "to take care of him." It is said that "Old Robin" was one of the best commissary assistants in Lee's army. 
born I787, marricd 1805. She was the daughter of Newton Hopkins, born about I764, and Patience Glenn, born I77I, who was the son of Colonel Lavid Hopkins, born 1737, and Mary Bowles. $\dagger$

Laurens Garlington Young is the son of John Laurens Young, $\$$ born I 820 , married I 857 , Susan Jane Garlington, born I832. He was a son of John Young, born I779, and Sarah Blackaby Maddox, il born I788, married I804. John Young was a son of William, born about I740, and Miss

Hunter (sister of U. S. Senator Judge Hunter), who was the son of Agnes Young.

†Colonel David Hopkins entered the South Carolina Rangers as a lieutenant and after fighting through the Revolutionary War came out a Lieutenant-Colonel. From him descended the Hunters, Peakes, and Normans of Union County; the McAulilys, Pattersons aud Wilkes of Chester County, and Hopkins of Richland County, South Carolina, and the Tomkins of DeSoto Parish, La.

tJohn Laurens Young in 1861 was president of the S. \& U. R. R. Co.; resigned this office and volunteered in Company A, 18th South Carolina regiment, C. S. A.; was transferred to the Confederate States Depositary, serving until the close of the war; was honorably discharged and accepted parole from President Johnson in September", 1865 .

||Sarah Blackaby Maddox was daughter of Justinian and Judith Maddox, of Culpepper County, Virginia, who moved to Laurens County, South Carolina, in 1799, together with Mrs. Maddox's father, who lived to the ripe old age of 100 years. Their other children were Annie, who married James Young, Susan, who married first Mr. Ligon, second Mr. Henderson, and third Samuel Vance. Judith married Alex Winn and moved to Alabama. John Maddox also moved to Alabama.

-Agnes Young moved from Maryland to Laurens County, South Carolina, in 1756 , a widow with 7 sons, all of whom fought for American Liberty. The big shop-made sword of (1) William's, is still preserved in the family; he was killed by "Bloody Bill Curlningham" in the raid terminating in Hay's Station Massacre in 1781. (2) Thomas settled in Union County and made a fine record with his three sons, Christopher, born 1772, Thomas, born 1758, and John, born 1756 . John was killed by the Tories near Sardis Church, 4 miles south of Union, S. C.; Major Thomas had his head split open at the battle of Cowpens and afterwards wore a silver plate in the wound, dying in 1848, leaving a number of children; Christopher survived and also left a large family. (3) Joseph settled near Hickory Nut Gap, N. C., and his son, Robert, is given credit, in Landrum's Colonial and Revolutionary History of South Carolina, of killing Colonel Ferguson at the battle of King's Mountain. (4) Sam and (5) James settled in Laurens County and left large families. (6) Hugh or (7) John, moved to Georgia or "went across the mountains." 
Susan jane Garlington was a daughter of John Garlington, born I7S4, married I830, Susan Washington James, born I8o4. John Garlington was a son of Edwin Garlington, born I740, and Susan Dickie, born I755. She was the daughter of John Dickie, who came from Scotland in I750. Edwin Garlington was the son of Elizabeth Conway, born 1705, and Christopher Garlington, whose father came from England before I65i. Elizabeth Conway was the daughter of Anne Ball, born i6 66 , and Colonel Edwin Conway, $\S$ born I68I, son of Edwin, I64I, son of Edwin, who came from Scotland in I6ro; from this line also descended President James Madison. Anne Ball was the daughter of Colonel Joseph Ball, born I649, of Epping Forest, Iirginia; his other daughter, Mary, was the mother of President George Washington. Susan WTashington (grandmother) was the daughter of Benjamin James, born I768, and

$\S$ Edwin Conway, Worcester, England, came to Virginia about 1610 and was clerk of Northampton County from 1642 to 1645 ; moved to Lancaster County and died before 1675. Married Martha, daughter of Richard Eltonhead of Lancashire, England, and left Edwin, of Lancaster County, Virginia, who died August, 1698, and had by his marriage with Sarah, daughter of Lieutenant-Colonel Henry Fleet, a son, Colonel Edwin Conway of Lancaster, a man of considerable prominence in his day and a member of the House of Burgesses from 1710 to 1742 . He married Anne, daughter of Colonel Joseph Ball, who died 1763, leaving with the other issue a daughter, Elizabeth, who married Christopher Garlington.

Lieutenant-Colonel Henry Fleet of Lancaster, was an incorporator of the 3rd Virginia charter in 1612 and a member of the first Maryland Assembly, 1637 to 1638 . Maryland Historical Society papers relating to early history of Maryland, pages 69 to 99 , in referring to Colonel Fleet, says: "he was an active man, a useful citizien, a shrewd lawyer, an excellent interpreter and contributed his full share towards laying the foundations of the colony of Maryland and building up the colony of Virginia." Hayden's Virginia Genealogy, page 232. 
Jane Stobo ; he was the son of John James and Anne Strother, who was the daughter of Benjamin Strother and Mrs. Mary (Mason) Fitzhugh, widow of George Fitzhugh, and daughter of George Mason of Gunston Hall, the author of the famous Virginia "Bill of Rights," who was the son of Colonel George Mason, an officer under Charles II of England. From Benjamin Strother's brother, Francis, descended President Zachary Taylor. Jane Stobo was the daughter of Richard Park Stobo and Mary Harvey, who was the son of James Stobo and Elizabeth, who was the son of Rev. Archibald Stobo, and his wife, Elizabeth Park. James' sister, Jean, married in I729 James Bulloch, and from them descended President Theodore Roosevelt.

ๆJohn James was Justice of Stafiord County, Va., in 1773. H:s son Benjamin, fought in the Continental Army. See Virgin:a Magazine of History and Biography, volume 18, pages 395-95; Records of Virginia and South Carolina Historical and Genealogical Magazine; Records of Historical Commission of South Carolina No. 150, Book F, and No. 207, Book C. The name of James is found among the very early settlers in Virginia and we find several of the name who occupied positions of importance. 
7. atenal monnth of d t 12

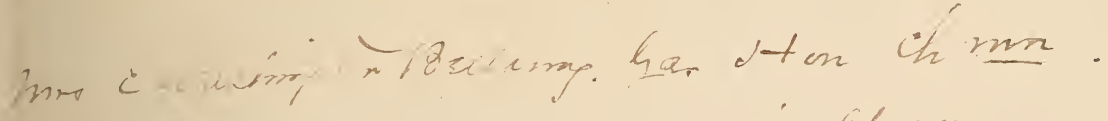

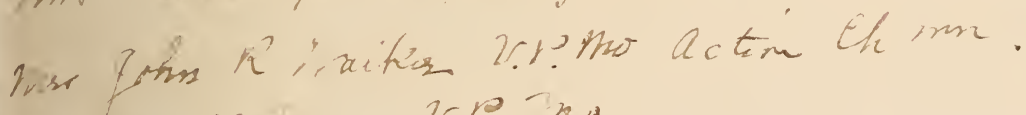

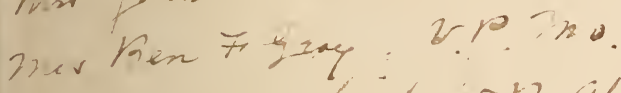

mos \& moman bownt ar. Ala.

mustrim an a andinglew. 2., TC.

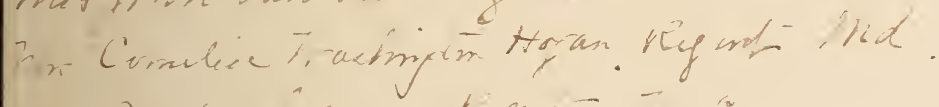

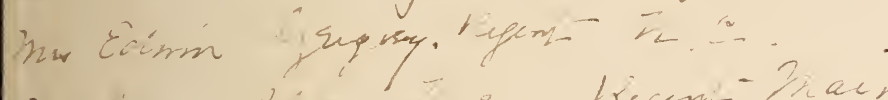

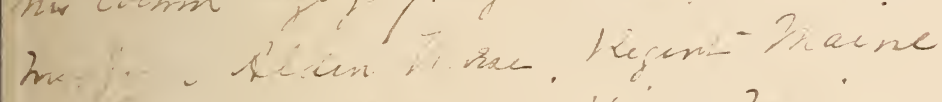

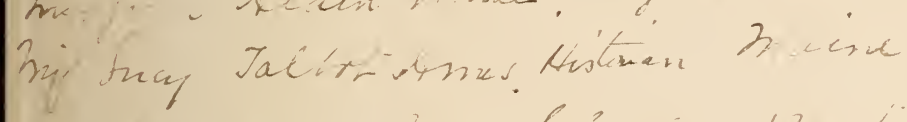

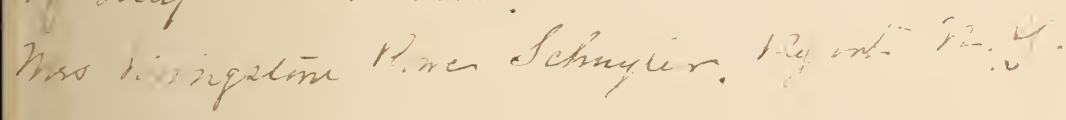

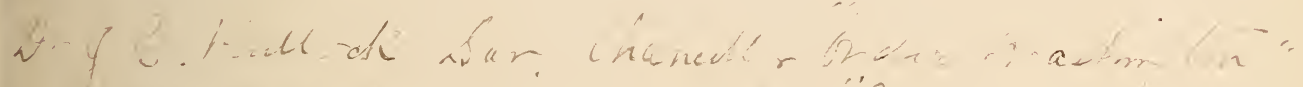

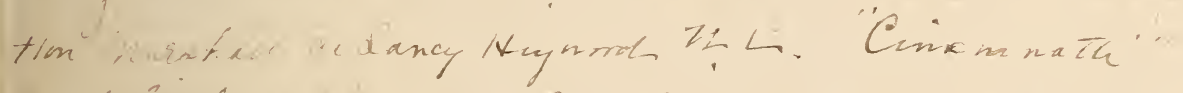

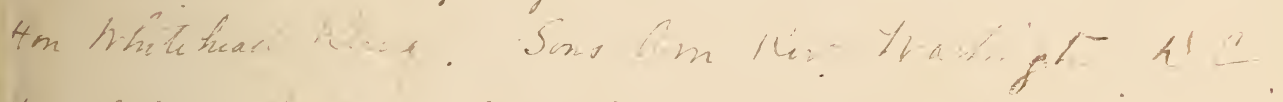

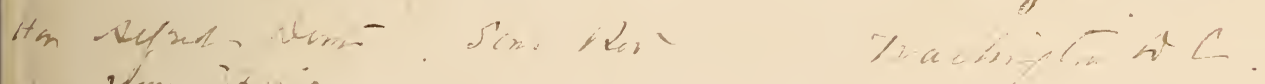

Ho. Itim isinie

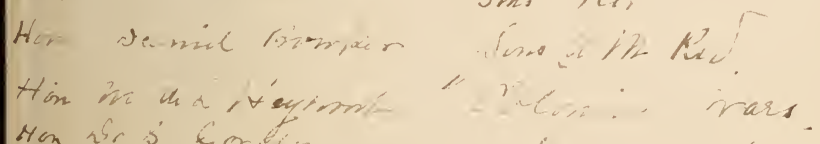

Hon is is Gortion 


